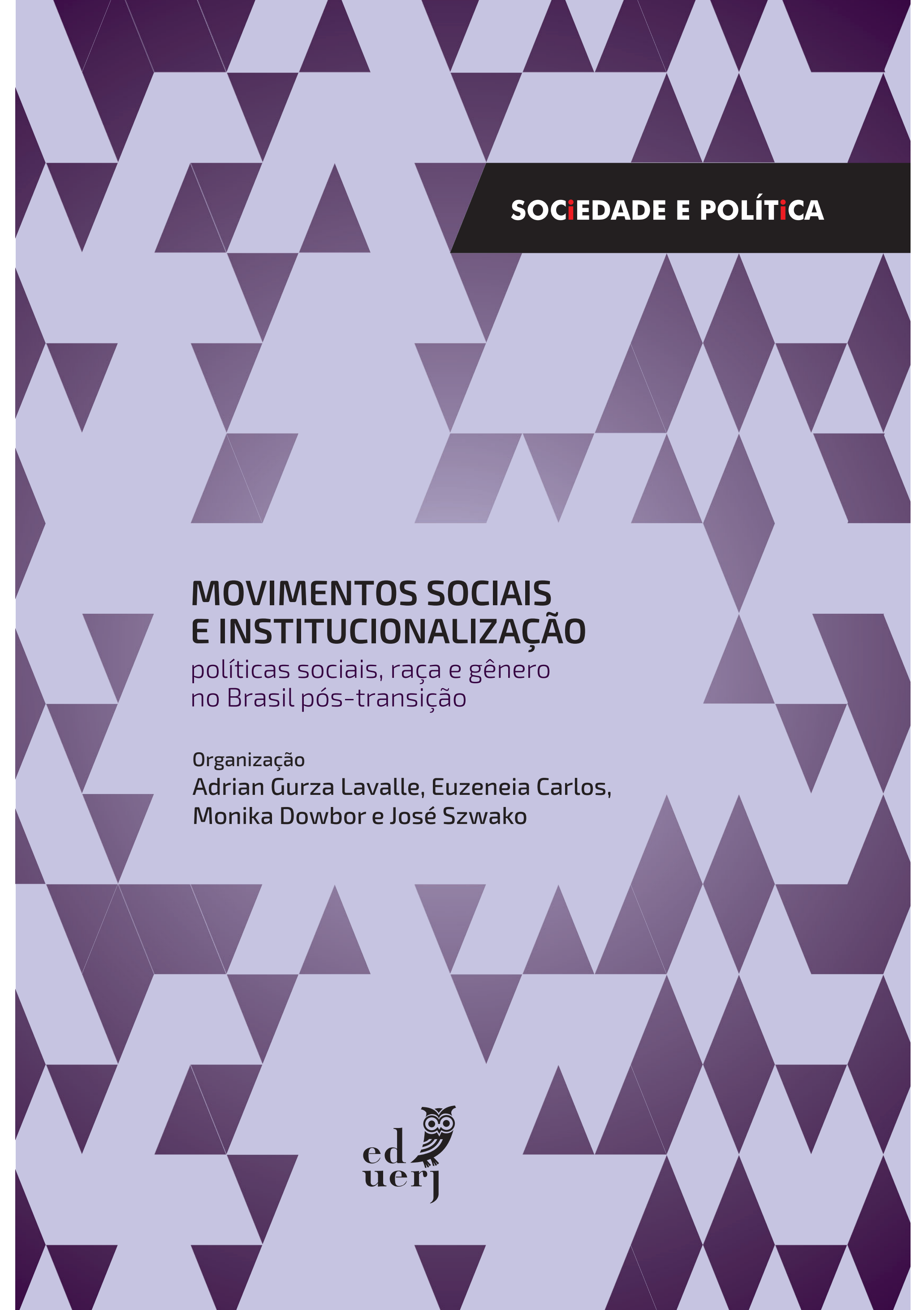




\title{
Movimentos sociais e institucionalização políticas sociais, raça e gênero no Brasil pós-transição
}

\author{
Adrian Gurza Lavalle \\ Euzeneia Carlos \\ Monika Dowbor \\ José Szwako \\ (orgs.)
}

\section{SciELO Books / SciELO Livros / SciELO Libros}

LAVALLE, A.G., CARLOS, E., DOWBOR, M., and SZWAKO, J., comps. Movimentos sociais e institucionalização: políticas sociais, raça e gênero no Brasil pós-transição [online]. Rio de Janeiro: EDUERJ, 2018, 411 p. Sociedade e política collection. ISBN: 978-85-7511-479-7. https://doi.org/10.7476/9788575114797.

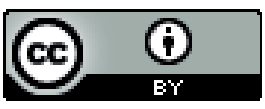

All the contents of this work, except where otherwise noted, is licensed under a Creative Commons Attribution 4.0 International license.

Todo o conteúdo deste trabalho, exceto quando houver ressalva, é publicado sob a licença Creative Commons Atribição 4.0.

Todo el contenido de esta obra, excepto donde se indique lo contrario, está bajo licencia de la licencia $\underline{\text { Creative }}$ Commons Reconocimento 4.0. 
Movimentos Sociais e Institucionalização

$$
\begin{gathered}
\text { políticas sociais, raça e gênero } \\
\text { no Brasil pós-transição }
\end{gathered}
$$


Ruy Garcia Marques

Vice-reitora

Maria Georgina Muniz Washington

$\begin{array}{ll}\text { ed } & \text { EDITORA DA UNIVERSIDADE DO ESTADO DO } \\ \text { uerj } & \text { RIO DE JANEIRO } \\ \text { Conselho Editorial } \\ \text { Glaucio José Marafon (presidente) } \\ \text { Henriqueta do Coutto Prado Valladares } \\ \text { Hilda Maria Montes Ribeiro de Souza } \\ \text { Italo Moriconi Junior } \\ \text { José Ricardo Ferreira Cunha } \\ \text { Lucia Maria Bastos Pereira das Neves } \\ \text { Luciano Rodrigues Ornelas de Lima } \\ \text { Maria Cristina Cardoso Ribas } \\ \text { Tania Maria Tavares Bessone da Cruz Ferreira } \\ \text { Anibal Francisco Alves Bragança (EDUFF) } \\ \text { Katia Regina Cervantes Dias (UFRJ) }\end{array}$

Instituto de Fstudes Sopiais e Polútion

Coleção Sociedade e Política

Coordenadores

Breno Bringel

João Feres Júnior

Conselho cientifico

Antônio Sérgio Guimarães (USP)

Fabiano Santos (IESP-UERJ)

Flávia Biroli (UnB)

Gilberto Hochman (FIOCRUZ)

José Maurício Domingues (IESP-UERJ)

Leonardo Avritzer (UFMG)

Maria Stella Grossi Porto (UnB)

Pablo Gentili (CLACSO)

Rachel Meneguello (UNICAMP)

Sergio Costa (Frei Universität - Alemanha) 


\title{
Adrian Gurza lavalle, Euzeneia Carlos, Monika Dowbor \& José Szwako \\ ORganizaÇÃo
}

Movimentos Sociais e Institucionalização

\author{
políticas sociais, raça e gênero \\ no Brasil pós-transição
}

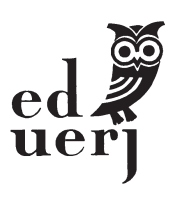

Rio de Janeiro 
Copyright (C) 2018, Dos autores.

Todos os direitos desta edição reservados à Editora da Universidade do Estado do Rio de Janeiro. É proibida a duplicação ou reprodução deste volume, ou de parte do mesmo, em quaisquer meios, sem autorização expressa da editora.

EdUERJ

Editora da UNIVERSIDADE DO ESTADO DO RIO DE JANEIRO

Rua São Francisco Xavier, 524 - Maracanã

CEP 20550-013 - Rio de Janeiro - RJ - Brasil

Tel./Fax.: 55 (21) 2334-0720 / 2334-0721

www.eduerj.uerj.br

eduerj@uerj.br

Editor Executivo

Coordenadora Administrativa

Coordenadora Editorial

Coordenador de Produção

Assistente Editorial

Assistente de Produção

Capa

Projeto Gráfico

Diagramação

Glaucio Marafon

Elisete Cantuária

Silvia Nóbrega

Mauro Siqueira

Thiago Braz

Érika Neuschwang

Júlio Nogueira

Emilio Biscardi

TypoAssim Design

Revisão

Miriam Junghans/IESP

\author{
CATALOGAÇÃO NA FONTE \\ UERJ/REDE SIRIUS/NPROTEC
}

M935 Movimentos sociais e institucionalização : políticas sociais, raça e gênero no Brasil pós-transição / Adrian Gurza Lavalle ... [et al.], organização. - Rio de Janeiro : EdUERJ, 2018.

410 p. - (Sociedade \& política)

ISBN 978-85-7511-480-3

1. Movimentos Sociais - Brasil. I. Lavalle, Adrian Gurza. 
“... democracy, once formed, does not stay in place forever. That is why sites of democracy always display the sign 'UNDER CONSTRUCTION'."

Charles Tilly

“... institucionalização é sempre um processo inacabado, em construção."

Renato Boschi 



\section{Sumário}

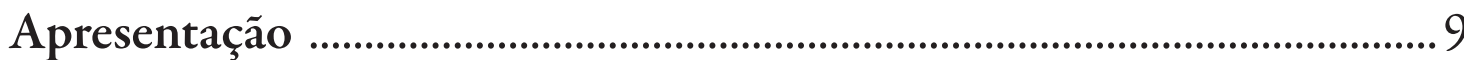

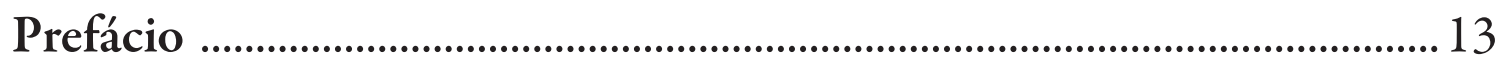

Abertura

Movimentos sociais, institucionalização e domínios de agência

Adrian Gurza Lavalle, Euzeneia Carlos, Monika Dowbor \&José Szwako

PRIMEIRA PARTE

MOVIMENTOS E POLÍTICAS SOCIAIS NO BRASIL PÓS-TRANSIÇÃO

Capítulo 1

Escapando das incertezas do jogo eleitoral: a construção de encaixes e domínio de agência do movimento municipalista de saúde

Monika Dowbor

Capítulo 2

A entrada dos novos imigrantes na política local de

São Paulo: domínio de agência e disputa partidária

Patrícia Tavares de Freitas

Capítulo 3

A construção de encaixes institucionais e domínio de agência no movimento popular urbano: mecanismos e configurações

Euzeneia Carlos 165

Capítulo 4

Analisando impactos do movimento social na construção da política socioeducativa: coalizões de defesa e encaixes

Maria do Carmo Albuquerque. 
SEgunda PARTE

MOVIMENTOS, RAÇA, GÊNERO E POLÍTICAS PÚBLICAS

Capítulo 5

Antirracismo, movimentos sociais e Estado (1985-2016)

Flavia Rios

Capítulo 6

Feminismos, movimentos de mulheres e as políticas de saúde para as mulheres

Layla Pedreira de Carvalho

Capítulo 7

Os movimentos negro e indígena e a política de saúde e de HIV/

Aids: institucionalização e domínio de agência

Vera Schattan Coelho \& Adrian Gurza Lavalle

Capítulo 8

Ideias e interações: a generificação de duas políticas públicas no Paraguai

José Szwako \& Renato Perissinotto.............................................................375

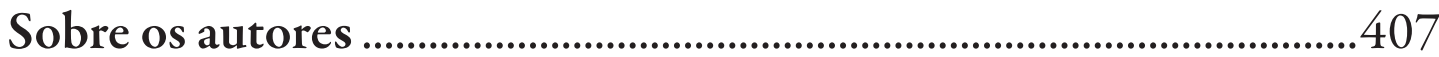




\section{APRESENTAÇÃO}

Este livro colhe os resultados de uma longa interlocução, de mais de dez anos, entre os pesquisadores do Núcleo de Pesquisa Democracia e Ação Coletiva (NDAC). Nesse sentido, trata-se propriamente de um livro coletivo e não de uma coletânea, pois exprime uma agenda construída coletivamente para entender as relações de mútua constituição entre sociedade civil e Estado, em que movimentos sociais são atores centrais. Exprime igualmente o amadurecimento de ferramentas analíticas que, em ação neste volume, foram pacientemente buriladas ao longo do tempo mediante o trabalho duplo da crítica de seus rendimentos na pesquisa empírica e da avaliação contínua das perspectivas analíticas que animam o conhecimento acumulado e seus avanços de fronteira.

Criado em 2006 e composto inicialmente por um grupo de jovens pesquisadores em diversos estágios na carreira sob a orientação do professor Adrian Gurza Lavalle - pesquisadores, por força do tempo e da competência, hoje doutores e professores em diversas universidades e instituições de pesquisa -, o NDAC realizou e continua a realizar pesquisas sobre padrões de interação Estado/sociedade em registros diversos: novas formas de representação política, instituições participativas, controle social e accountability, interfaces entre instituições políticas e atores sociais, redes de organizações civis e sua transversalidade com atores estatais, e construção política das organizações civis. Entre esses registros, aquele dedicado a pensar as capacidades dos atores sociais como uma construção política definida por processos de interação 
com instituições e atores estatais que, a um só tempo, modificavam as capacidades estatais, ganhou centralidade porque se evidenciou como perspectiva analítica profícua para entender o papel dos movimentos sociais na transformação das políticas públicas sociais ocorrida no período da pós-transição. Como o leitor poderá apreciar no livro, as perspectivas analíticas disponíveis para se entender as mudanças nos padrões de interações socioestatais próprios desse período são insatisfatórias porque seus pressupostos analíticos e conceitos não permitem apreender adequadamente os fenômenos da institucionalização de demandas, valores e recursos de ação dos movimentos sociais e suas consequências para a produção e a operação das políticas públicas.

Não cabe, nesta apresentação, entrar nos argumentos substantivos do livro nem nos resultados originais de pesquisa acerca dos diferentes movimentos sociais, organizações da sociedade civil e setores de políticas abordados nos capítulos. A esse respeito, convidamos o leitor a continuar o caminho pelas páginas que se seguem. Aqui gostaríamos de explicitar o estilo de trabalho, bem como o rico entorno institucional e apoios que tornaram possíveis o desenvolvimento de teoria e resultados de pesquisa ora apresentados. Junto das atividades de pesquisa, individuais ou coletivas, o trabalho do Núcleo é distinguido por intenso processo de formação. Sine ira et studio, as reuniões de discussão e leitura de textos são como rituais nos quais pesa o ritmo lento de reflexão - a despeito da urgência das tarefas, pressões de prazos e exigências da produção acadêmica atual. Sejam textos clássicos, produções mais recentes ou textos dos pesquisadores do NDAC, a palavra na primeira rodada do dia está, por princípio, reservada aos mais jovens e apenas depois deles aos mais sêniores na carreira. Como conceito, trata-se de incentivar a participação almejando amadurecimento na exposição das ideias e no raciocínio claro e estruturado. Após a discussão sistemática do texto, o exercício do livre pensar também tem espaço entre nós, explorando conexões possíveis com outras 
bibliografias, forjando nossos referenciais teórico-analíticos, afinando a linguagem e as lentes para analisar nossos objetos de pesquisa. Por sua vez, as atividades de pesquisa conciliam o trabalho individual, por regra associado aos projetos de mestrado e doutorado, com trabalho coletivo propiciado por projetos institucionais sob responsabilidade dos pesquisadores com maior senioridade no Núcleo. O convívio nos trabalhos de investigação e as afinidades intelectuais tornam o NDAC, enfim, um espaço para desenhar e fazer pesquisas por meio de nossos afetos e afinidades. Apesar de alguns de nós estarmos fisicamente distantes do contato com o NDAC em São Paulo, o Núcleo segue até hoje nutrindo laços afetivos e produzindo desafios intelectuais - como este livro.

Certamente, um estilo de trabalho como o descrito depende de amparo institucional capaz de prover um entorno estimulante para o crescimento intelectual e para travar contato de primeira mão com a produção nacional e internacional de ponta, suporte para formação de competências em metodologia de pesquisa, bem como apoio material na forma de infraestrutura e de financiamento para a pesquisa. O NDAC é a esse respeito privilegiado por dupla inserção institucional em centros de excelência, amplamente reconhecidos pela vitalidade de sua vida interna e pela relevância do conhecimento que neles se produz. Criado e sediado como Núcleo de Pesquisa do Centro Brasileiro de Análise e Planejamento (Cebrap), o NDAC integra também as atividades de pesquisa do Centro de Estudos da Metrópole (CEM) na sua qualidade de Centro de Pesquisa, Inovação e Difusão (Cepid), financiado pela Fundação de Amparo à Pesquisa do Estado de São Paulo (Fapesp). Sem o amparo institucional de ambos os centros, este livro não seria possível.

Os capítulos deste livro se vinculam a projetos de pesquisa desenvolvidos pelos autores e coautores, financiados por agências de fomento em três modalidades principais, a saber, auxílio à pesquisa, bolsa de pós-doutorado e bolsa de doutorado. Os organi- 
zadores e os colaboradores agradecem ao Centro de Estudos da Metrópole (CEM), à Fundação Ford e à Fundação de Amparo à Ciência e Tecnologia do Município de Vitória (Facitec), pelos auxílios concedidos à pesquisa. Ao Conselho Nacional de Desenvolvimento Científico e Tecnológico (CNPq) e à Coordenação de Aperfeiçoamento de Pessoal de Nível Superior (Capes), pelas bolsas de doutorado. José Szwako, Monika Dowbor e Patricia Tavares de Freitas agradecem expressamente ao CEM e à Fapesp pelas bolsas de pós-doutorado. A publicação deste livro não teria sido possível sem o apoio do CEM, do Instituto de Estudos Sociais e Políticos da Universidade do Estado do Rio de Janeiro (IESP/UERJ) e da EdUERJ. 


\section{PRefácio}

Nas décadas de 1990 e 2000, o Brasil apareceu no cenário internacional como foco de experimentação criativa na produção de políticas públicas que envolviam movimentos sociais no interior do processo decisório. Nos anos 1990, eram os orçamentos participativos e outras iniciativas locais, bem como a criação de sistemas de políticas públicas com participação em nível nacional, tais como o Sistema Único de Saúde. Nos anos 2000, especialmente a partir de 2003 com o advento do governo federal do Partido dos Trabalhadores, essa experimentação subiu de escala com o fortalecimento de conselhos e conferências, e uma diversidade de outros tipos de arranjos participativos que envolveram movimentos sociais não somente na formulação das políticas, mas também na sua implementação.

Ao lado dessa experimentação na prática, surgiu uma literatura acadêmica que também experimentou, contribuindo de maneira original para os estudos de movimentos sociais, democracia e sociedade civil. Num primeiro momento, isso envolveu reacender o antigo debate sobre democracia participativa, agora em torno de experiências reais muito mais amplas em termos numéricos do que havia acontecido no passado em outros lugares do mundo (com a exceção, talvez, da experiência do estado indiano de Kerala, que também envolveu milhões de pessoas). Uma literatura inicialmente ufanista e militante foi rapidamente complementada por pesquisas empíricas bem fundamentadas que revelavam as complexidades e limitações das iniciativas participativas. Ao mes- 
mo tempo, estudiosos começaram a ampliar o olhar em várias direções. Enquanto alguns examinaram a inserção das instituições participativas em estruturas políticas e partidárias mais amplas, outros estudaram as diversas maneiras por meio das quais atores sociais interagiam com o Estado para além de instituições formalmente criadas para tanto.

A criatividade na prática política foi acompanhada pela criatividade intelectual. Extrapolando o terreno das instituições participativas, as análises testaram os pressupostos de boa parte da bibliografia sobre movimentos sociais que os concebia como essencialmente externos à estrutura do Estado e que presumia que a proximidade de movimentos às instituições políticas implicaria necessariamente na sua desmobilização. Os estudos brasileiros mostraram o contrário: que movimentos podiam interagir sistematicamente com instituições estatais, em dinâmicas não necessariamente desmobilizadoras. Demonstrou-se também que a aproximação entre movimentos e governos não é novidade no Brasil: atores de movimentos sociais negociavam com e até participavam em governos muito antes da ascendência da esquerda ao poder governamental. Mesmo nos governos petistas, a proximidade entre movimentos e alguns atores estatais não implicou na ausência de conflitos. Muitas vezes, porém, esses se manifestavam não tanto como contendas entre atores no Estado e outros na sociedade, mas entre atores que defendiam projetos distintos, ocupando arenas estatais diferentes, com suas respectivas alianças na sociedade.

A maior parte desse debate escolheu como marco conceitual de diálogo as teorias de movimentos sociais e de sociedade civil, deixando de lado uma melhor compreensão teórica do que acontecia no interior do Estado. A criação de instituições eficazes de acesso de movimentos ao Estado foi frequentemente vista em termos vagos que deixaram mais perguntas do que respostas, como foi o caso do conceito de "vontade política", usado por muitos 
estudiosos para explicar a eficácia maior de algumas instituições participativas.

Este livro surge como importante contribuição para corrigir este viés "centrado na sociedade" ao privilegiar a compreensão da natureza do Estado no que diz respeito a sua relação com os movimentos. Percebendo as limitações da literatura sobre participação e movimentos sociais para esse fim, os autores embarcaram em uma viagem de reconhecimento e captura de conceitos do neoinstitucionalismo histórico, campo pouco conhecido pelos estudiosos de movimentos sociais brasileiros. A leitura que fazem dessa literatura é cuidadosa e seletiva, privilegiando autores mais “sociológicos", como Evans, Skocpol e Mann, que oferecem ricos trabalhos conceituais sobre a natureza e funcionamento das organizações estatais. Também resgatam debates sobre intermediação de interesses no corporativismo e pluralismo.

No encontro dessas literaturas, os autores constroem um marco conceitual próprio para entender como a institucionalização de demandas de movimentos sociais ocorre e para explorar as consequências para a capacidade dos movimentos de influenciar o processo de decisão governamental. Conceitos como "encaixe" e "domínio de agência”, que o leitor conhecerá a fundo nas páginas a seguir, nos oferecem uma gramática para tornar visível a variedade de maneiras em que movimentos sociais participam de instituições de políticas públicas. Os capítulos empíricos avançam mais ainda, explorando como esses conceitos podem ser utilizados e oferecendo teses para explicar como os pontos de acesso para movimentos chegam a ser institucionalizados no interior do Estado. Demonstram de maneira detalhada como diferentes histórias de organização e interação entre movimentos e políticas públicas resultam em uma variedade enorme de estruturas de acesso. A permeabilidade do Estado é definitivamente heterogênea.

A obra avança o atual debate brasileiro sobre o papel dos movimentos nas políticas públicas em uma direção especialmente 
importante. Em uma etapa anterior muito frutífera, as pesquisas passaram de um foco centrado na "participação" dos movimentos sociais para o exame da "interação" entre movimentos e Estado. Assim começaram a desconstruir a noção de que o encontro entre atores do Estado e da sociedade consistia em uma espécie de conversa através de grades que separavam dois mundos. Na presente obra, os autores vão além: propõem pensar não somente na interação, mas também na "mútua constituição" de movimentos e Estado.

Trata-se de dois passos simultâneos na crítica ao pressuposto de que os movimentos operariam de maneira independente do Estado. Primeiro: os movimentos são profundamente influenciados pelas políticas públicas e pelas regras institucionais que definem suas formas de participação. Segundo: essas políticas e regras foram criadas em grande parte a partir de processos de construção institucional em que os próprios movimentos participaram. Assim, para além da ideia de interação, a noção de mútua constituição sugere que os atores nos movimentos e nas agências estatais não apenas se interrelacionam a partir de terrenos institucionais fixos, mas participam na construção destes.

Ao tratar de maneira teoricamente substanciada da mútua constituição da sociedade civil e do Estado, os autores buscam dar continuidade a um debate truncado que surgiu em torno da publicação da coletânea Bringing the State Back In, organizada por Peter Evans, Dietrich Rueschemeyer e Theda Skocpol, em 1985. Vários intérpretes acusaram a perspectiva associada a esse livro, que veio a ser chamada de perspectiva "centrada no Estado", de atribuir causalidade excessiva ao Estado nos processos sociais e políticos. Duas obras articularam importantes respostas a essas críticas ao teorizar o Estado e a sociedade como mutuamente constituídos: The Sources of Social Power de Michael Mann (1993) e Embedded Autonomy de Peter Evans (1995). Essa investida conceitual e empírica no estudo dos impactos mútuos de organizações 
da sociedade e do Estado, no entanto, não proliferou, talvez em função do crescimento, nos anos 1990, do debate em torno do neoliberalismo.

Mais recentemente, Evans e Mann participaram do debate em torno do conceito de "capacidade estatal", questionando a associação entre capacidade e impermeabilidade do Estado. Os autores do presente volume encontram nesse debate várias pistas para a proposta da mútua constituição. Um dos conceitos centrais apresentados no livro - os "encaixes" que institucionalizam o acesso de atores sociais ao Estado - é adaptado a partir de uma obra de Skocpol, escrita nos anos 1990 em parte para defender a perspectiva "centrada no Estado", então sob ataque. A autora desafiava a proposta "centrada na sociedade" de autores como Putnam, que atribuía o desempenho estatal unicamente ao que poderíamos chamar de capacidade societária. Skocpol argumentou que as associações são profundamente influenciadas pelas políticas e práticas governamentais. Talvez por isso, ela não traz instrumentos conceituais suficientes para entender como a sociedade participa na constituição dos "encaixes".

O presente livro contribui de maneira significativa para preencher esta lacuna e assim empurrar a abordagem neoinstitucionalista de autores como Skocpol um pouco mais para além da dicotomia entre perspectivas centradas na sociedade e no Estado. Inspirados na discussão sobre a mútua constituição de Estado e da sociedade presente na literatura sobre o corporativismo societal, os autores abordam os mecanismos de construção de domínios de agência, por meio dos quais em décadas recentes uma heterogeneidade de organizações não corporativistas adquiriu acesso institucionalizado ao Estado. Como nos sistemas corporativistas, a criação desses "domínios de agência" transforma não somente a estrutura estatal, mas também as práticas sociais. Ao oferecer categorias analíticas para definir os diferentes modos pelos quais "encaixes institucionais" operam na intermediação de interesses, 
os autores adicionam preciosos conceitos à nossa caixa ainda bastante vazia de ferramentas teóricas para enxergar e explicar a complexa relação entre movimentos e instituições. Os organizadores deste livro, junto com os autores dos capítulos, apresentam, assim, mais uma contribuição criativa e inovadora do pensamento político-social brasileiro à literatura internacional sobre a relação entre sociedade e Estado.

Rebecca Abers (UnB) 
ABERTURA 



\title{
Movimentos sociais,
}

\author{
INSTITUCIONALIZAÇÃO E \\ DOMÍNIOS DE AGÊNCIA
}

\author{
Adrian Gurza Lavalle ${ }^{1}$ \\ Euzeneia Carlos \\ Monika Dowbor \\ José Szwako
}

\section{Introdução ${ }^{2}$}

A institucionalização pública estatal de formas de controle e incidência social sobre políticas públicas e de instâncias de participação, agendas oriundas da sociedade civil, bem como das categorias nativas que sintetizam o sentido dessas agendas, ordenando as práticas dos atores sociais, é fenômeno dos mais notáveis do Brasil pós-transição e, no entanto, jaz na penumbra deitada pelas prin-

1 Os autores agradecem o apoio do Centro de Estudos da Metrópole (Cepid-CEM), financiado pela Fundação de Amparo à Pesquisa do Estado de São Paulo (Fapesp), processo $n^{\circ}$ 2013/07616-7. As opiniões, hipóteses e conclusões ou recomendações expressas são de responsabilidade dos autores e não necessariamente refletem a visão da Fapesp.

2 Versões preliminares deste trabalho foram apresentadas em sessões especiais no Congresso Nacional de Ciências Sociais, Universidade Federal de Espírito Santo (Conacso/Ufes, setembro 2015) e no III Encontro Internacional Participação Democracia e Políticas Públicas (III PDPP/Ufes, maio 2017). Agradecemos os comentários certeiros de Marisa von Bülow e Rebecca Abers, debatedoras de nosso trabalho, respectivamente, em cada um desses eventos. Também somos gratos e gratas aos membros do Núcleo Democracia e Ação Coletiva (NDAC) pela intensa interlocução ao longo de numerosas sessões discutindo a abordagem de domínios de agência. A responsabilidades por falhas persistentes é, evidentemente, apenas nossa. 
cipais literaturas que, em princípio, estariam orientadas a iluminá-lo. A relação entre "o poder social”, ou a organização coletiva de interesses e valores, e "o Estado", ou as instituições políticas e da administração pública, tem sido objeto de teorização - quer em registro realista ou normativo - por três corpos teóricos influentes: pluralismo, neocorporativismo e teorias dos movimentos sociais. Por motivos a serem explorados ao longo destas páginas, pressupostos analíticos cruciais desses corpos teóricos ora eclipsam os processos de institucionalização, ora reduzem sua diversidade e induzem leituras peculiarmente restritivas dos mesmos. Essas lentes, argumenta-se, não permitem apreender a especificidade dos padrões de interação socioestatais que contribuíram decisivamente, no país, para moldar a atuação setorial do Estado - em saúde ou assistência social, para mencionar apenas dois exemplos emblemáticos abordados neste livro - ou o desenho de políticas mais específicas - o campo da saúde para a população negra ou a política de HIV, para permanecer em casos do terreno da saúde também examinados nestas páginas. Tampouco contribuem, na direção inversa, para compreender a atuação dos movimentos sociais (doravante MSs) ou das organizações da sociedade civil (doravante OSCs) e sua capacidade de incidência sobre as políticas sociais no contexto da pós-transição.

Repare-se, o fenômeno notável que ocupa as páginas deste trabalho é a "institucionalização" e não as “instituições”. Enquanto o segundo termo pressupõe a fixidez de atributos e permanência temporal daquilo que é, o primeiro opera como um verbo substantivado e remete ao devir, mais especificamente ao processo de institucionalizar, de transformação de algo em instituição. É a transformação em instituições de valores, interesses, demandas e recursos de atuação de MSs e OSCs atuando em nome de grupos marginalizados e agendas tradicionalmente periféricas ao sistema político que se impôs como novidade histórica demandando explicação àqueles que estudam movimentos sociais. Assim, ocupar-se 
da institucionalização no Brasil pós-transição não apenas dista de ser fortuito, como oferece uma perspectiva privilegiada de interrogação da literatura pluralista, neocorporativa e de movimentos sociais que evidencia suas lacunas. Certamente a institucionalização não é fenômeno exclusivo da pós-transição nem, é claro, da história nacional: outros atores historicamente posicionados em condições favoráveis para imprimir seus interesses nas decisões de autoridades públicas, notadamente atores de mercado e/ou corporativos, receberam atenção das literaturas pluralista e neocorporativa. Em boa medida, essas literaturas desenvolveram-se analiticamente graças ao foco naqueles atores e na política de defesa de seus interesses. Entretanto, a novidade histórica dos anos da pós-transição no país tornou pertinente desenvolver perspectivas analíticas para lidar com a institucionalização em relação a uma constelação de atores tradicionalmente pensados em registro de contestação e para os quais - conforme será mostrado - os registros analíticos predominantes resultam insatisfatórios. Mais: as lacunas detectadas sob o prisma dos processos de institucionalização que aqui interessam permitem projetar implicações analíticas gerais, e não apenas para determinado conjunto de atores em determinado tempo ou espaço.

Para apreender os processos de institucionalização, o neo-institucionalismo histórico, sensível ao estatuto causal dos processos temporais - sequências, trajetórias, cadeias causais, dependência da trajetória (Mahoney, 1999, 2000) -, oferece registro analítico que permite assumir o caráter mutuamente constitutivo das relações entre Estado e sociedade civil. Nesse sentido, constitui perspectiva especialmente oportuna para examinar e entender os processos de institucionalização de interesses, valores e agendas sociais e de constituição de capacidades estatais como produto de interações socioestatais. A intuição básica quanto ao caráter constitutivo dessas interações não é novidade e é possível encontrá-la em pleno funcionamento no trabalho espantosamente lúcido de 
Peter Nettl (1968) sobre o Partido Social-Democrata Alemão (1890-1914) como modelo político. Isto é, duas décadas antes da obra coletiva seminal de Evans, Rueshermeyer e Skocpol (1985) dedicada a trazer o Estado de volta; obra não raro referida como certidão de nascimento da primeira geração do neo-institucionalismo histórico. Não é gratuito que Nettl seja referência constante nessa obra.

Nos trabalhos dessa geração de neo-institucionalistas históricos, a interpenetração entre Estado e sociedade civil foi alçada ao plano da teoria e dos conceitos. Da perspectiva dos atores sociais, a proposta seminal foi de Theda Skocpol (1992). Denominada por ela de polity approach - abordagem do corpo político ou da polis, em tradução aproximada -, centrou nos processos de interação socioestatais que permitiam aos atores sociais ora se adequar favoravelmente ao - e tirar vantagens para a mobilização do - contexto institucional maior, ora "cavar espaços ou entradas" ou, mais propriamente, arquitetar encaixes institucionais no Estado (engineering fit). Assim, em Skocpol o conceito encaixe ( $f i t)$ outorgou concreção institucional aos resultados das interações socioestatais. Isto porque, se sob determinadas circunstâncias, os processos de interação permitiam aos atores sociais arquitetar encaixes no Estado - pontos de acesso (points of access), órgãos, regras, prioridades, leis -, a seletividade intrínseca às instituições passaria a funcionar favorecendo esses atores tornando o Estado continuamente poroso aos seus interesses e valores.

E mais: além e ao lado da noção de encaixes institucionais, o neo-institucionalismo histórico legou ainda o foco de análise nas capacidades estatais. Se nas suas primeiras formulações, a produção de C. Tilly (1975) e T. Skocpol (1979) estava atenta a macroprocessos de State building, aos graus de controle (ou descontrole) sobre partes da população e do território, a agenda da década seguinte enfatizou as capacidades estatais como traço distintivo da autonomia do Estado. A inflexão dessa agenda enfática quanto 
à autonomia do Estado, prévia ao polity-approach, inspira nossa agenda de pesquisa porquanto aponta para a permanência e pertinência analíticas das capacidades estatais como dimensão central na compreensão da institucionalização das demandas e interesses dos MSs e OSCs vis-á-vis o Estado. Assim, a agenda centrada na institucionalização pode observar o fenômeno quer da perspectiva dos atores sociais quer da perspectiva dos atores estatais, sem abrir mão de uma abordagem processual que assume o caráter mutuamente constitutivo das relações entre Estado e sociedade civil. Dado nosso interesse nos MSs e OSCs, a primeira perspectiva recebe maior tratamento analítico nestas páginas, mas a segunda também é abordada.

Aquelas ideias e conceitos seminais aventados por Skocpol, todavia, permaneceram subteorizados. Argumenta-se aqui que as distinções analíticas pioneiras cunhadas pelo neo-institucionalismo histórico carecem de especificação sistemática quanto à sua variabilidade empírica em três dimensões: (i) os tipos de encaixes institucionais e suas especificidades ou variação horizontal; (ii) a hierarquia política ou variação vertical em que operam encaixes e, por fim, (iii) a articulação entre diversos encaixes posicionados em níveis distintos de hierarquia política, isto é, suas configurações. Quanto à variação horizontal dos tipos de encaixes, há diversas formas em que o Estado e a administração pública tornam-se porosos aos interesses sociais mediante expedientes que comportam graus diversos de institucionalização. Ter o acesso franqueado para dialogar regularmente com um funcionário público chave, ocupar cargos, determinar uma regra, definir uma função institucional, criar um órgão incumbido de certos propósitos - inclusive garantir a participação de determinados segmentos da população - ou aprovar uma lei, para mencionar apenas alguns exemplos, constituem formas consideravelmente diversas de ativar favoravelmente a seletividade das instituições, e embora todas elas possam ser concebidas analiticamente como encaixes, suas implicações são 
distintas. A variabilidade em questão é horizontal porque desconsidera a posição específica da inserção dos encaixes no arcabouço institucional. Por isso as distinções analíticas pertinentes não remetem apenas à diversidade das feições desses encaixes, mas ao fato de os encaixes - inclusive os "mesmos" encaixes - poderem operar em níveis diferentes de autoridade. É a variação vertical ou, lançando mão de metáfora topográfica, "altitude" política que remete à hierarquia e permite atentar para a durabilidade dos encaixes e sua capacidade de subordinar instâncias inferiores à seletividade por eles introduzida, reduzindo a contingência dos interesses beneficiados por tais encaixes. Assim, sem levar em consideração a disposição horizontal e vertical dos encaixes, torna-se difícil apreciar a diferença entre uma coleção de encaixes avulsos e sua articulação em configurações de maior estabilidade, alcance e potência.

A abordagem aqui desenvolvida atenta, precisamente, para processos de institucionalização que geraram configurações de encaixes de alcance médio, situadas além de encaixes pontuais ou relativamente desarticulados e tendencialmente instáveis, e aquém das cristalizações institucionais de alto alcance e feições quase pétreas descritas pela literatura neocorporativa. Configurações de encaixes derivadas de processos de interação socioestatal, institucionalmente cristalizadas em níveis de hierarquia intermediários constituem dominios de agência, cujas propriedades distintivas definem a capacidade de ação dos atores aos que se reconhece agência em um âmbito de atuação específico. Como domínios de agência não nascem prontos, mas são produto de histórias de conflito, aprendizagem e cooperação, eles possuem perfis distintos; isto é, cada domínio responde a uma articulação de elementos produzidos em diferentes momentos: regulações, repertórios de atuação considerados legítimos e capacidades de ação dos atores sociais e do Estado. No plano empírico, estudos em profundidade constituem uma escolha propícia à identificação desses elementos; antes, obviamente, é mister delimitar os conceitos e suas relações, bem 
como aquilo que se entende por institucionalização e seu alcance. Essa tarefa receberá atenção nas páginas que se seguem.

Assim, após a formulação geral da questão nos termos expostos acima, o desafio está posto: iluminar ou retirar analiticamente da penumbra um conjunto de processos de institucionalização especialmente relevantes para o diagnóstico das transformações nas relações entre o Estado e os movimentos sociais no Brasil pós-transição. Com o intuito de avançar nessa direção, o objetivo deste capítulo introdutório é triplo: primeiro, examinar criticamente as abordagens disponíveis na literatura para se entender processos de institucionalização de interesses, valores e recursos de atuação de atores sociais de modo a evidenciar suas contribuições e limitações; segundo, desenvolver e mostrar os ganhos cognitivos de uma proposta de abordagem - a do dominio de agência - orientada pelo pressuposto da mútua constituição, radicalmente relacional e centrada em processos de institucionalização de alcance médio. Terceiro, e em consonância com esse pressuposto, estender os ganhos cognitivos para o Estado, argumentando o caráter reciprocamente determinante entre capacidades estatais e interações socioestatais: a capacidade acumulada (assim como a falta dela) modela, por via de configurações de encaixes e interações (indireta ou diretamente), as formas e estratégias pelas quais atores não estatais interpelam o Estado, assim como os instrumentos estatais de ação e intervenção são incrementados, entre outros fatores, pelo arco das interações travadas com MSs e OSCs - diremos: esses instrumentos têm gênese sociopolítica.

Por fim, e no intuito de evitar mal-entendidos, cabe reiterar: é a dissonância entre as expectativas analíticas geradas pelas teorias disponíveis e as características distintivas dos domínios de agência emergidos no país no contexto do pós-transição que tem animado não apenas esta proposta, mas um movimento mais geral da literatura nacional de revisão de pressupostos teóricos e 
inovação conceitual. ${ }^{3}$ Embora as motivações derivem de preocupações contextuais - o cenário do Brasil pós-transição -, entendemos que toda preocupação é em maior ou menor medida contextual e que, por isso, sua relevância supõe o esforço de explicitar suas implicações de caráter geral. Isto é, uma abordagem teórica sobre os processos de institucionalização que definem as relações entre o Estado, os movimentos sociais e a sociedade civil não é, evidentemente, uma teoria sobre o Brasil, mas tornou-se pertinente porque informada pela experiência histórica do país. Conforme apontado, trata-se de processos carregados de significação teórica porque revelam aquilo que escapa aos arcabouços conceituais que utilizamos para pensar o mundo e, também, porque trazem à tona um conjunto de fenômenos que quiçá passaram despercebidos em outros contextos. Assim, a perspectiva de encaixes e domínios de agência aqui desenvolvida permite diagnosticar os processos empíricos de institucionalização ocorridos no pós-transição - notadamente sob as administrações do Partido da Social Democracia Brasileira e do Partido dos Trabalhadores -, mas a perspectiva analítica não se confunde com uma tese histórica e preserva seus conceitos e indagações básicas para contextos de governos com orientações partidárias e ideológicas as mais díspares - inclusive de cunho regressivo, como o que seguiu ao impeachment da presidente Dilma Rousseff. As configurações mudam conforme a coalizão governante, cedendo passo a outros atores e outros encaixes inscritos em diversos níveis de autoridade. Isso não significa que as configurações de encaixes e a operação de domínios de agência sejam menos relevantes, mas apenas que são outros os atores a serem analisados e outras também as redes transversais ao Estado em que esses atores disputam as decisões das autoridades públicas e constroem políticas. Nada mais, porém, nada menos. Restam as questões analíticas de fundo, mas não é possível derivar respostas

3 Para um balanço desse movimento ver Gurza Lavalle e Szwako (2015). 
dedutivamente; antes, os diagnósticos dependem do esforço coletivo da pesquisa empírica.

O arco da argumentação contempla vários passos: as seguintes duas seções estabelecem interlocução com a literatura com o intuito de mostrar os efeitos de ocultação por ela gerados sobre os processos de institucionalização que aqui interessam; depois, abordamos a proposta dos domínios de agência em diálogo com os desdobramentos mais recentes do neo-institucionalismo histórico e explicitamos sua adequação para apreender tais processos de institucionalização; por fim, à luz da trajetória ocupada pela noção de capacidades estatais no neo-institucionalismo, argumentamos que ela é noção heurística duplamente fértil, seja para iluminar as formas pelas quais o Estado molda as chances de acesso e resultados dos MSs e das OSCs, seja para compreender em que medida, por meio de quais instrumentos e interações, atores não estatais podem incrementar as capacidades do Estado. A última seção oferecerá uma síntese completa dos capítulos que integram o livro.

\section{O poder social e a institucionalização de interesses}

O pluralismo é uma teoria realista da organização do poder social ou da organização coletiva de interesses e valores e sua relação com as instituições incumbidas de tomar e implementar decisões vinculantes em sociedades com regimes democráticos. Embora existam discordâncias a respeito da presença de compreensões pluralistas originais e de orientação radical - deslocadas pelo pluralismo do segundo pós-guerra - ou, nas últimas décadas, pluralistas culturais, as quais obstariam compreensões unitárias ou de linhagem única do próprio pluralismo, parece incontroverso que aquela sintetizada na primeira frase deste parágrafo é de longe a versão mais conhecida do pluralismo e aquela que ocupa, na ciência política, a posição de compreensão mais influente da relação entre poder social e instituições políticas 
democráticas (Schlosberg, 1998). Pelo menos desde o famoso Prefácio à teoria democrática de Robert Dahl (1956), restou assente que as democracias garantem a presença dos interesses sociais tanto na formação de governos mediante as eleições quanto na tomada de decisões sobre políticas entre eleições e mediante processos em maior ou menor medida regulados de influência sobre o governo - manifestações, opinião pública, lobby (Truman, 1951; Dahl, 1961). Em sociedades complexas, diferenciadas e de mercado, tipicamente correlacionadas com regimes democráticos, não existiria um centro dominante de poder, mas um policentrismo expresso por excelência no pluralismo organizacional próprio dessas sociedades (Dahl, 1991). Interesses organizados - "associações", na linguagem pluralista - buscariam defender suas posições e fazer avançar suas prioridades nas decisões em que, eventualmente, resultariam afetados. As democracias pluralistas são, assim, regimes em que a disputa pela organização de poder social e sua influência sobre as autoridades ou poder público é lícita. A compreensão é realista porque centrada em interesses particulares, mesmo que coletivos, e porque as decisões das autoridades exprimem o resultado dessa disputa (Marques, 1997).

O pluralismo não permite assimilar em seu arcabouço analítico a institucionalização da capacidade de ação de atores sociais no Estado, embora privilegie o conflito pela influência do poder social sobre as autoridades. De um lado, a ação do Estado apenas é compreensível se levadas em consideração as pressões sociais sobre ele - em linguagem alheia ao pluralismo, as interações socioestatais -, de outro, o próprio Estado é uma arena de disputa, munido de recursos controlados por burocracias com prioridades e interesses próprios, não coincidentes com essa ou aquela expressão do poder social. Assim, o Estado toma decisões que favorecem determinados interesses, em detrimento de outros, como resultado da disputa pluralista entre atores, e não porque privilegie sempre os mesmos atores. Por outras palavras, há predomínio de interesses particulares, 
mas não é invariável e, por isso, não constitui dominação, pois as associações beneficiadas pelas decisões públicas variam conforme a área da decisão e conforme a disputa da vez (Dahl, 1991). ${ }^{4}$ A perspectiva pluralista ilumina as causas que determinam decisões públicas, algumas das quais supõem a institucionalização de interesses dos atores vencedores em detrimento daqueles derrotados. Emblematicamente, leis são aprovadas porque, após barganha, negociação e pressão social, certos interesses se impõem sobre outros. Contudo, tal institucionalização diz respeito aos resultados ou benefícios das decisões públicas e não à capacidade da atuação em face do ou dentro do Estado. Processos de institucionalização que garantem o acesso permanente de certos interesses às instâncias de tomadas de decisão outorgariam a eles vantagens contínuas, envergando o funcionamento do Estado sistematicamente ou definindo permanentemente a seletividade das instituições em favor de certos grupos. Isso comprometeria o caráter do Estado como arena em disputa e ameaçaria introduzir distorções permanentes indesejáveis - dominação até - com efeitos corrosivos sobre a pluralidade de interesses organizados, e, por conseguinte, sobre os pressupostos analíticos do pluralismo.

A limitação recém-assinalada dista de ser original: a crítica mais contundente ao pluralismo pela incapacidade de oferecer uma leitura razoável da institucionalização de interesses nas sociedades democráticas remonta aos anos 1970 e veio da literatura neocorporativa. Mais: a literatura neocorporativa demarcou suas diferenças distintivas em relação ao pluralismo e à ambição de oferecer uma proposta analítica alternativa e realista do funcionamento das democracias nos contextos do segundo pós-guerra (Schmitter, 1974). Por sinal, fora do campo da teoria democrática também houve críticas que apontaram à especificidade das dinâmicas insti-

Tal formulação é uma resposta às críticas dirigidas contra o pluralismo pelo marxismo (Manley, 1983). 
tucionais do Estado e, em especial, da operação de políticas públicas: comunidades e redes de políticas, ou coligações reformistas ou de advocacy, para mencionar apenas alguns avanços nesse campo de estudos, implicam conformações socioestatais em maior ou menor medida estáveis de atores e interesses na definição de políticas (Knoke, 1996; Sabatier, 2007; Sabatier e Weible, 2007; Kingdom, 1995). O foco da literatura neocorporativista nas estruturas de intermediação de interesses, cuja expressão por excelência foram as instâncias nacionais de negociação tripartite entre Estado, sindicatos (trabalho) e federações de empregadores da indústria (capital), acarretou implicações corrosivas para o pluralismo, pois tais estruturas constituíam uma verdadeira anomalia para essa abordagem e, no entanto, multiplicaram-se como um expediente de negociação do conflito social em larga escala nas democracias avançadas. No diagnóstico da literatura neocorporativa, além de o pluralismo se revelar inacurado no terreno empírico e deficiente no plano teórico, trazia consigo consequências normativas indesejáveis, pois o pluralismo organizacional enfraquecia a capacidade de representação e negociação dos atores sociais em face do Estado e do poder econômico. Assim, sacrificar a pluralidade de vozes para alcançar a capacidade de "falar mais alto" era entendida como a escolha correta. Nas palavras incisivas de P. Schmitter: "as associações pluralistas enfraquecem o papel dos intermediários de interesses; as corporativistas o fortalecem" (1992, p. 439; Schmitter, 1974, pp. 97-109).

A literatura corporativa e, em particular, Schmitter em seus textos seminais sobre o corporativismo no século XX e a representação de interesse de grupos nos contextos de pós-transição democrática, iluminaram uma dupla dinâmica na institucionalização de estruturas de intermediação de interesses entre o Estado e atores sociais relevantes. Primeiro, a institucionalização para o e no Estado reconhecia e concedia capacidade de representação a atores sociais e assegurava essa capacidade concedendo-lhes o 
monopólio de representação de interesses sociais de grupos amplos, o acesso a recursos estáveis e o controle de barreiras de entrada para dificultar a emergência de concorrência na representação de tais interesses, garantindo, precisamente, o monopólio. Esse é emblematicamente o caso das centrais sindicais no mundo do trabalho e dos mecanismos institucionais a elas vinculados em combinações diferentes conforme o contexto nacional: filiação compulsória, taxas ou cotizações descontadas diretamente no hollerith (imposto sindical), representação sindical única por local de trabalho e por setor, representação reconhecida pelo Estado e pelas entidades patronais nas negociações salariais e de outros benefícios e condições de trabalho. A mesma caracterização pode ser aplicada a partidos políticos, investidos do monopólio de representação e assegurados por diversos direitos e benefícios nas arenas eleitoral e parlamentar do governo representativo. Graças a sua presença nas estruturas de intermediação de interesses como o parlamento, partidos adquirem poder de incidência direta sobre a alocação de recursos públicos e sobre a definição de diretrizes da ação do Estado, bem como capacidade de proteger seus interesses - assumindo que coincidem em algum grau com aqueles dos segmentos sociais em nome dos quais falam - e de impor perdas a outros grupos sociais. Assim, a institucionalização para o e no Estado a um só tempo constitui e constrange a capacidade de ação do próprio Estado, impregnando-a com um viés sistemático em favor dos atores representados.

A segunda dinâmica de institucionalização é na direção dos atores sociais, aquilo que Schmitter chamara de propriedades emergentes derivadas de tal institucionalização. Em troca da influência adquirida graças à institucionalização, atores sociais cedem controle ao Estado que, mediante legislação, regula-os definindo o alcance da representação, fontes lícitas e ilícitas de financiamento, atividades permitidas e interditadas, e feições básicas da organização interna. Sindicatos e partidos, por exemplo, exercem monopólio da representação restrito a determinada esfera da vida 
social, os primeiros não podem financiar os segundos e estes são proibidos de receber recursos oriundos de outros governos e organizações estrangeiras; direções sindicais precisam ser eleitas, diferentemente das partidárias, e os partidos precisam de estatuto e programa definidos conforme às disposições da lei correspondente. Em suma, para dizê-lo com a conhecida fórmula de Claus Offe (1998, pp. 225-268), a concessão ou atribuição de status público a um conjunto de atores sociais amplia sua capacidade de ação e, a um só tempo, supõe a intervenção reguladora do Estado.

A institucionalização não apenas constitui foco privilegiado da literatura neocorporativista, mas ganha densidade analítica mediante conceituação em registro configuracional - ou seja, mediante a caracterização de configurações -, pois a intermediação de interesses é realizada em determinadas posições institucionais estruturas -, cuja estabilidade e autoridade derivam, por sua vez, de sua inserção em arcabouços institucionais maiores. Em Schmitter, tais configurações são definidas como regimes. As estruturas de intermediação de interesses respondem às mesmas feições básicas já aludidas, mas dependendo da sua posição em relação ao arcabouço institucional do regime constitucional democrático e aos modos possíveis de expressão e representação de interesses - cidadãos, associações ou grupos, e classes ou sindicatos - configuram um regime específico de representação de interesses. Assim, nos termos de Schmitter (1992), as democracias seriam um compósito de regimes de representação, dentre os quais o regime eleitoral constitui apenas um, conectando cidadãos/eleitores, partidos e parlamento. As estruturas de intermediação corporativas do mundo do trabalho constituem o regime de concertação, que conecta atores dos interesses empresariais e trabalhistas com os órgãos centrais de decisão do governo. Ao mundo das organizações civis e movimentos sociais, bem como dos grupos de interesses, corresponde aquilo que Schmitter chamou de modo indiferenciado de regime de pressão - 
uma espécie de categoria ou regime residual que englobaria o universo dos atores analiticamente privilegiados pelo pluralismo. ${ }^{5}$

Sem dúvida, atentar para a hierarquia ou altitude política na defesa de interesses dos atores sociais é traço distintivo da abordagem neocorporativa, e, nesse sentido, estruturas de concentração de poder adquirem saliência, pois é nelas que se ganha efetividade da representação de interesses. Assim, a perspectiva neocorporativa é particularmente propícia para iluminar configurações altamente cristalizadas e operantes em níveis de autoridade elevados. Não é fortuito que a literatura neocorporativa esteja sendo revisitada para interpretar o cenário das inovações participativas na América Latina (Chartock, 2013; Collier e Handlin, 2009; McNulty, 2013; Boschi, 2010), pois enseja afinidade analítica para a interpretação da institucionalização de instâncias que conferem protagonismo a setores sociais subalternos ou historicamente sub-representados nos circuitos tradicionais da representação.

Pois bem, os atores dos processos de institucionalização que nos ocupam neste momento histórico - OSCs e MSs - são consideravelmente mais heterogêneos que os atores protagônicos do neocorporativismo e a eles não é concedido monopólio algum da representação, embora sejam reconhecidos como atores com capacidades e, por vezes, funções de representação de determinados grupos sociais (Rezende, 2015; Gurza Lavalle e Isunza, 2011; Gurza Lavalle, Houtzager e Castello, 2006a, 2006b). Mais: a heterogeneidade guarda vínculo com uma diferença crucial, qual seja, a inexistência de interesses incontroversos a serem representados com prioridade sobre quaisquer outros interesses. Isto é, o mundo do trabalho não foi substituído por outro âmbito capaz de determinar sujeitos presuntivamente portadores de interesses univer-

\footnotetext{
5 No debate mais recente sobre a chamada crise da representação, as ideias de regimes de interesses de Schmitter passaram a ser exploradas pela literatura como diferentes circuitos da representação em registro pós-liberal (ver Schmitter, 2005; Arditi, 2005; Vite, 2005; Zaremberg, Gurza Lavalle e Guarneros-Mesa, 2017).
} 
sais ou superiores. Reconhece-se que interesses afetados precisam ser representados, mas tais interesses são diversos e não coincidem com um único porta-voz, antes, diversos atores concorrem com posições conflitantes. Logo, embora às OSCs e aos MSs seja atribuído status público na realização de certas funções, inclusive de representação, e existam canais institucionalizados de intermediação com o Estado como as chamadas instituições participativas mas não só -, trata-se de arranjos plurais. Ademais, tais arranjos, a despeito de sua institucionalização, são visivelmente vulneráveis e instáveis em comparação às instituições corporativas, e amiúde operam em regiões de intermediação ou altitude política de alcance médio, mediante um conjunto assaz diverso de canais de acesso ao funcionamento do Estado. Essa região mal corresponde ao chamado regime de pressão da abordagem neocorporativa, pois as distinções desenvolvidas com acuidade analítica para compreender o neocorporativismo do mundo do trabalho não encontram equivalente analítico com aderência empírica ao mundo heterogêneo da sociedade civil e aos arranjos institucionais que o vinculam com o Estado. ${ }^{6}$

\section{Movimentos sociais e institucionalizações}

As abordagens pluralista e neocorporativa privilegiam analiticamente a inserção de interesses organizados em instâncias públicas incumbidas de tomar decisões, iluminando a institucionalização de interesses ora como resultado dessa influência sobre as decisões, na perspectiva pluralista, ora como monopólio da representação em instâncias de intermediação, no registro neocorporativo. Em ambos os casos, a capacidade de incidência desses interesses não é uma questão. No registro pluralista assume-se que

6 Para uma tentativa de incorporar explicitamente as OSCs e MSs no enquadramento neocorporativo ver Schmitter (1993). 
onde há interesses intensos eles se organizam ou associam e, uma vez organizados, as respectivas associações reagem quando os efeitos de decisões públicas colocam em jogo tais interesses; por outras palavras, associações são o desdobramento natural da intensidade de preferências nas sociedades organizadas politicamente em democracias (Dahl, 1991). Interesses desorganizados, não manifestos ou sem capacidade de incidência não são objeto de preocupação analítica. Por sua vez, no registro neocorporativo a capacidade de incidência dos sindicatos é um dado da história política do século XX e não precisa ser explicada. Apenas assume-se que quando determinados atores adquirem saliência suficiente para a reprodução da sociedade, eles tendem a ser reconhecidos e a tornar-se objeto da atribuição de status público, experimentando a dupla dinâmica da institucionalização descrita acima: aumento de influência sobre o Estado em troca de controle pelo Estado (Offe, 1998).

Para a literatura de MSs a institucionalização de movimentos e das suas demandas é questão relevante e, no entanto, teoricamente ambivalente quanto aos seus efeitos. De um lado, uma parte desse campo de investigação, ao privilegiar o confronto e posições dicotômicas entre movimento e Estado, identifica os processos de institucionalização com desmobilização e cooptação. De outro, avanços recentes ampliam e complexificam as formas de ação e organizacionais ao incluir aspectos de institucionalização, mas de forma pontual e sem dar conta dos processos e seus efeitos nos movimentos sociais e suas demandas. Nos parágrafos a seguir explicita-se o lugar analítico dos processos de institucionalização na literatura de movimentos sociais, mostrando de que maneira os conceitos de encaixes e domínios de agência aumentam a capacidade de analisar os movimentos quando estes adentram as instituições e institucionalizam suas demandas e sua posição em diversos setores de políticas públicas, notadamente, os das políticas sociais.

As principais e mais difundidas ênfases teórico-analíticas das teorias dos movimentos sociais elaboradas pelos autores 
radicados nos EUA não permitem descrever e explicar os processos de institucionalização que permeiam as interações dos movimentos sociais com o Estado para além da desmobilização e da cooptação. Isto, primeiro, porque pressupõem uma separação entre movimentos e a política institucionalizada, e analisam a sociedade e o Estado a partir de categorias estanques, como entidades autônomas e dicotômicas (outsider vs insider, challenger vs authority); e segundo, porque se baseiam em um modelo conflituoso de ação, construído dentro das relações de poder do sistema político que implica confronto entre atores não institucionalizados e institucionalizados (Tarrow, 1997; McAdam, Tarrow e Tilly, 2001; Tilly e Tarrow, 2007).

Um efeito dessas ênfases é a impossibilidade de se explorar a diversidade de interações entre os movimentos e o Estado, entre as quais estão as que se efetuam por meio das instituições e junto a atores institucionalizados. A exclusão do fenômeno supramencionado influiu na produção de uma noção estreita de institucionalização na literatura, focada nas ações de confronto político e nas organizações de movimentos. Se a institucionalização da ação equivale ao protesto rotinizado, no caso das organizações, a institucionalização implica uma complexificação organizacional do movimento, a qual é remetida à rotinização, previsibilidade, formalização, profissionalização e oligarquização da ação coletiva (Kriesi, 1999), e/ou à sua transformação em um ator institucionalizado como, por exemplo, em grupo de interesse ou partido político (Kriesi, 1999). Em ambos os casos, haveria como consequência a mudança nos objetivos que levaram a fundação do movimento no sentido da desradicalização, a eventual cooptação dos ativistas e, por fim, a desmobilização.

As ênfases no caráter confrontacional e conflituoso entre movimentos sociais e Estado e na separação analítica entre ambos foram contestadas por um conjunto de autores que introduziram 
aspectos da institucionalização sem associá-los, necessariamente, à cooptação de ativistas e à desmobilização de movimentos. As pesquisas conduzidas no Brasil (Abers e von Bülow, 2011; Abers, Serafim e Tatagiba, 2014; Carlos, 2012; Dowbor, 2012; Szwako, 2012; Silva e Oliveira, 2011; Tatagiba e Blikstad, 2011; Alonso, Costa e Maciel, 2007) e alhures (Banaszak, 2005; Goldstone, 2003; McAdam e Scott, 2005; Clemens, 1993, 2005; Giugni e Passy, 1998) demonstram que os movimentos sociais não podem ser reduzidos analiticamente às ações da política de confronto desencadeadas e sustentadas por organizações e redes informais. Esses estudiosos trazem novos elementos para descrever as interações via instituições entre movimentos e Estado, a partir de três assertivas. Primeira: os movimentos sociais se engajam em um conjunto de atividades que não necessariamente implicam a relação de conflito com os detentores de poder; em sociedades complexas, movimentos também cooperam com o Estado, colaborando na elaboração e implementação de políticas governamentais (Giugni e Passy, 1998; Carlos, 2012, 2015). Segunda: os movimentos sociais combinam uma pluralidade de formas de relação com o Estado, em modelos híbridos e criativos que promovem a articulação circunstancial entre ação institucionalizada e não institucionalizada (Abers, Serafim e Tatagiba, 2014; Carlos, 2012; Dowbor, 2012). Terceira: o uso de canais institucionalizados no repertório de ação e a formalização das organizações não leva obrigatoriamente à desmobilização do movimento (Carlos, 2012; Dowbor, 2012).

Mais concretamente, do ponto de vista analítico, o repertório de ação de movimentos sociais foi ampliado. Passaram a ser incluídas as interações cooperativas ou colaborativas entre movimentos e atores institucionais em torno da produção de políticas públicas (Giugni e Passy, 1998), bem como as interações por meio dos canais de acesso mais ou menos institucionalizado às agências do Estado, tais como lobby, instituições participativas e contato com os representantes políticos, entre outros (Abers, Serafim e 
Tatagiba, 2014, p. 346). As organizações de movimentos passaram a incluir variados tipos e a ser vistas como parte das estratégias de ação, mesmo quando acionadas sob formas altamente formalizadas (McAdam e Scott, 2005; Goldstone, 2003; Hanagan, 1998; Clemens, 1993).

Em outras palavras, os movimentos não necessariamente se movem num continuum de formas de ação menos institucionalizadas a mais institucionalizadas. Eles fazem uso diversificado e, por vezes, simultâneo dessas formas e ações a depender da análise das oportunidades e ameaças políticas. Com isso, torna-se possível romper com o diagnóstico da desmobilização e/ou cooptação como resultado necessário da simples existência de ações via instituições. Tampouco existiria a transformação linear das formas organizacionais - de informais e espontâneas a altamente formalizadas, as primeiras correspondendo à mobilização do movimento e, as segundas, à desmobilização e transformação do movimento em um ator institucionalizado.

O afrouxamento das fronteiras analíticas entre o caráter confrontacional e cooperativo, e entre o caráter não institucionalizado e institucionalizado das ações e organizações de movimentos sociais nessas novas perspectivas é salutar e permitiu incorporar nas análises as instituições estatais e os atores do sistema político. Neste sentido, passou-se da análise de ações unilaterais do movimento para a análise de interações entre movimento e Estado. Contudo, tratadas de forma indiscriminada como ações do repertório, as ações extrainstitucionais e via instituições têm todas o mesmo peso analítico, enquanto sabemos que podem ter efeitos distintos nas trajetórias de movimentos e no grau de sua influência nos processos decisórios. Ou seja, ao repertório de interação falta a abrangência analítica para iluminar os graus de institucionalização da ação e, com isso, identificar a capacidade de influência do movimento, bem como a própria institucionalização de partes do movimento. 
Por isso, precisamos de categorias que permitam observar os MSs em interação com as instituições do Estado e detectar as gradações de permanência e de influência dos atores sociais nos processos decisórios e seus efeitos. Categorias capazes de descrever os processos que consistem em buscar pontos de acesso ao Estado e em delimitar possíveis áreas de atuação reconhecidas pelo Estado, bem como fontes para a obtenção de recursos públicos sob o controle das organizações de movimentos. A abordagem da polity e seu conceito central, encaixe institucional, elaborados por Skocpol (1992), e revisados e expandidos por nós para o plano analítico de configurações de encaixes no interior da abordagem do domínio de agência oferecem essas lentes analíticas. As mudanças nos movimentos em termos de sua continuidade, desmobilização, cooptação ou transformação em outro formato de ação coletiva constituem, nesse sentido, possibilidades e não fatalidades que emergem necessariamente dos processos de institucionalização de médio alcance.

Porém, embora os receios da literatura quanto à institucionalização dos movimentos - de seus canais de diálogo com o Estado, seus repertórios e até de suas demandas - tenham imposto custos cognitivos, encerram uma questão de fundo que resta em pé após as críticas. Após a inclusão conceitual da institucionalização, o que garante que o fenômeno estudado ainda é, analiticamente, um movimento social? Há duas respostas para esta pergunta que estabelecem fronteiras analíticas próprias a esse tipo de ação coletiva. Em primeiro lugar, o ponto de partida dos estudos deve ser a operacionalização e a aplicação do conceito de movimentos sociais, que os distingue enquanto fenômeno de outros atores da sociedade civil. Esta reconstrução não é atemporal e genérica. Precisa ser feita num dado período histórico de modo que sejam evidenciados os elementos constitutivos do conceito como interações informais entre indivíduos, grupos e organizações, identidade coletiva e ações (Diani, 2003). Os conceitos de repertório de interação e 
de encaixes permitem acompanhar o desenvolvimento dessa ação coletiva, que adentra as instituições do Estado, e observar a institucionalização de canais de acesso, de demandas e de organizações, ainda no escopo do conceito de movimento.

Em segundo lugar, ao invés de deduzir a desmobilização e, uma vez pressuposta, simplesmente atestá-la mediante a pesquisa empírica, como o quer a teoria do confronto político, a observação dos processos de institucionalização permite avançar e mostrar a transformação da ação coletiva. Embora o conceito movimento social suponha, ao frisar a palavra informal, que se trata de uma forma instável de ação coletiva, reproduzir e permanecer nessa informalidade não precisa ser e amiúde não é um objetivo em si dos MSs. A razão é simples e traz consigo implicações profundas: a informalidade aumenta a contingência dos resultados da disputa política; por outras palavras, MSs estão em primeira instância comprometidos com a defesa de agendas substantivas e a institucionalização é um recurso para fazer avançar tais agendas e protegê-las das contingências da política. Perenizar os valores e interesses defendidos mediante a institucionalização é um resultado possível e inclusive almejável de processos de mobilização que não ocorre de modo unidirecional nem é definido de uma só vez, em um único momento ou circunstância. Assim, cabe ao analista observar os processos de institucionalização e, em última instância, identificar o ponto a partir do qual certas configurações de encaixes sedimentadas ao longo do tempo graças à ação coletiva trazem consigo a transformação do movimento social em questão em algum outro tipo de ator.

\section{Das variações horizontal, vertical e configuracional: encaixes e domínios de agência}

O neo-institucionalismo histórico oferece um registro alternativo graças, em primeira instância, a um pressuposto básico: o 
caráter mutuamente constitutivo das relações entre Estado e sociedade civil. O pressuposto é marca distintiva que subjaz os trabalhos dessa perspectiva, mas certamente é possível encontrá-lo em outros registros analíticos, por exemplo, nas reinterpretações de linhagem gramsciana da sociedade civil (Dagnino, 2011). De fato, ao longo das duas últimas décadas, o pressuposto tem sido explorado e tematizado continuamente pelos autores deste capítulo em registro crítico em relação à literatura de movimentos sociais e da sociedade civil (Gurza Lavalle, 1999; Houtzager, Gurza Lavalle e Acharya, 2004; Gurza Lavalle, Acharya e Houtzager, 2005; Gurza Lavalle, Houtzager e Castello, 2012; Carlos, 2012, 2015; Dowbor, 2012; Szwako, 2012, 2013; Gurza Lavalle e Szwako, 2015).

$\mathrm{Na}$ tradição neo-institucionalista o pressuposto da mútua constituição entre Estado e sociedade civil significou, já no começo dos anos 1990, um afastamento ante posturas State-centered e sua excessiva ênfase na autonomia das políticas - ênfase própria da primeira geração que trouxe, conforme mencionado na introdução, "the State back in". Centrar a análise na autonomia do Estado não foi operação analítica trivial, quando considerado que as compreensões predominantes propunham macro-interpretações de classe ou de fundo funcionalista modernizante para explicar as políticas de welfare (Skocpol, 1992). O Estado e sua atuação eram, assim, derivados de lógicas externas, a saber, da estrutura da sociedade. Contudo, a ênfase na autonomia do Estado cedeu passo a formulações analiticamente mais sofisticadas em que conceitos e explicações expressam interações socioestatais. Assim, Peter Evans (1995) reformulou seu diagnóstico acerca do sucesso de políticas de desenvolvimento em função da autonomia das instituições estatais incumbidas de definir tais políticas e avançou interpretação em que a inserção (embeddedness) do Estado em âmbitos societários era condição sine qua non de tal sucesso. Evans postulou, assim, benefícios funcionais para a capacidade de coordenação do Estado quando capaz de operar com autonomia socialmente inserida (embedded autonomy). 
$\mathrm{Na}$ condição de pressuposto, o caráter mutuamente constitutivo opera implicitamente guiando o olhar do neo-institucionalismo, mas não foi objeto de teorização. Para nós, a lógica de mútua constituição implica não apenas considerar incorretas e cognitivamente custosas compreensões dualistas e dicotômicas entre Estado e sociedade civil, mas ir além de compreensões contextualistas - comuns inclusive no neo-institucionalismo histórico - e entender a relação entre ambos de modo endogênico, interacionista e codeterminante. Que as instituições do Estado não pairam no ar desencarnadas das disputas políticas e dos interesses sociais, e que a sociedade civil e os MSs são simultaneamente estabilizados pelos direitos fundamentais consagrados constitucionalmente e constrangidos pelos marcos legais das sociedades em que atuam, são diagnósticos em maior ou menor medida pacíficos nas ciências sociais - embora não o sejam suas implicações. Contudo, pensar o Estado como contexto da sociedade e vice-versa é insuficiente. ${ }^{7}$ Interesses sociais organizados não apenas pressionam externamente o Estado - ao estilo pluralista -, mas são encarnados e ganham expressão institucional no Estado. Como argumentado há mais de um século e meio por Marx e pelo marxismo (e antes por Hegel), Estado e sociedade guardam vínculos constitutivos internos. Contudo, nem a sociedade civil pode ser absorvida no Estado, como queria Hegel, nem o Estado pode ser reduzido à sociedade civil, como queria Marx. As capacidades de ação de atores sociais e instituições políticas são politicamente produzidas (gênese) pelas disputas entre atores estatais e sociais. A construção política dessas capacidades decorre de processos de interação entre os atores, processos condicionados pelos resultados das interações prévias. No

\footnotetext{
Como será visto ainda nesta seção, o caráter contextual dessas relações tornase pertinente quando comparam-se escalas distintas na mesma análise; por exemplo, ações de escala micro condicionadas por regulações macro. Contudo, as regulações macro também foram politicamente produzidas por atores agindo nessa escala.
} 
processo histórico dessas interações ocorre a codeterminação ou mútua constituição entre Estado e sociedade civil.

Especificamente para questão que aqui interessa, e a despeito de sua subteorização no neo-institucionalismo histórico, o pressuposto da mútua constituição levou à construção de conceitos que permitem iluminar a relação entre institucionalização e movimentos sociais. Aqui a contribuição seminal foi de Skocpol (1992, pp. 47-54), formulada sob o título de abordagem da polis (polity approach) em seu Protecting Soliders and Mothers e ancorada no conceito encaixe institucional (institutional fit). A abordagem ensejou desdobramentos analíticos e de pesquisa em duas direções complementares - contextual e relacional -, mas com implicações teóricas distintas para a compreensão da ação coletiva. De um lado, em registro contextualista, a proposta da autora estimulou estudos atentos à influência institucional do Estado e do sistema político sobre a disposição de agir e as capacidades de ação dos atores sociais; de outro, em registro relacional e atento à gênese, animou indagações debruçadas sobre a construção histórica dessas capacidades em termos da moldagem de encaixes institucionais ou entradas preferenciais (points of access) arquitetados pelos atores sociais no Estado (engineering fit). No primeiro caso, a adequação ou encaixe ( $f$ it) das formas e recursos organizacionais dos atores ao contexto macro e meso institucional favoreceria sua capacidade e disposição de agir. Corresponderia àquilo que Skocpol (2008) denominou de "efeitos indiretos" do Estado sobre a ação dos atores sociais. No segundo caso, as instituições não são contexto externo, mas produzidas no processo de construção das capacidades de ação dos atores ou, de modo mais preciso, embora abstrato, são endógenas ao processo estudado e não exógenas ou meramente contextuais. O primeiro registro é de índole tipicamente institucionalista e constitui expressão específica da tese geral "instituições importam" (institutions matter); já o segundo acusa a raiz sociológica do neo-institucionalismo histórico e é eminentemente relacional. 
É esse registro relacional próprio da sociologia política que interessa radicalizar aqui. Em todo caso, Skocpol articula ambas as possibilidades em seus trabalhos mantendo o mesmo conceito (Skocpol, 1992; Skocpol e Crowley, 2001; Skocpol, 2003).

Nos últimos anos, as duas direções registraram avanços significativos com implicações críticas para as teorias dos movimentos sociais, em particular para os autores inscritos na vertente do processo político. Em alusão a eles, Edwin Amenta et al. (2002) argumentaram que o Estado permanece infrateorizado pela contentious politics e que noções como "oportunidade política" tendem a repor a dicotomia entre atores estatais e não estatais. Como corolário, a crítica levou seus autores a forjar o modelo da "mediação política" (Amenta et al., 2005) e a questionar quais variáveis propriamente institucionais explicam os efeitos dos movimentos sobre a institucionalidade (Amenta et al., 2010). Em Amenta, a "caixa preta" Estado é examinada em suas dimensões internas - estrutura de autoridade, elites, eleições, políticas, burocracias e partidos -, mas as instituições permanecem em boa medida em registro contextual. Por outro caminho, Elisabeth Clemens se dedicou aos encaixes institucionais, partindo, porém, de uma dimensão negligenciada nos estudos do processo político: a sua lógica organizacional. Essa autora se volta para as inovações no "repertório organizacional" das mulheres estudadas por Skocpol, bem como para os efeitos dessas inovações na interação com o arcabouço institucional político estadunidense (Clemens, 1993). Em Clemens (1993), o repertório organizacional apenas faz sentido se entendido relacionalmente. Amenta e Clemens constituem esforços notáveis de desenvolvimento do neo-institucionalismo histórico para sanar seu subdesenvolvimento teórico no estudo dos MSs e ambos proveem distinções analíticas que fazem render os princípios ou pressupostos básicos dessa vertente do neo-institucionalismo e, mais especificamente, da obra de Skocpol nas duas direções apontadas. 
A compreensão dos processos de institucionalização dos MSs permanece, todavia, subexplorada e subteorizada. Em Skocpol os encaixes institucionais carecem de especificação sistemática e são simplesmente definidos como a adequação entre os objetivos e capacidades dos atores sociais e os pontos mutáveis de acesso ao Estado, sendo que essa adequação aumenta o acesso e alavanca a capacidade de ação desses atores (Skocpol, 1992, pp. 41, 54 e ss.). Encaixes, todavia, variam quanto às suas feiçóes básicas e quanto ao nível de autoridade em que operam, e tais qualidades também variam quanto aos seus efeitos sobre a propensão dos atores sociais a agir e a fazê-lo com êxito. A baixa especificação analítica do conceito encaixes levou a autores como Houtzager e Kurtz (2000; Houtzager, 2004) a qualificar um tipo de encaixe mais potente - "vínculos estruturais" -, propício para a articulação de atores coletivos.

Aqui, evitamos a acepção contextualista dos encaixes institucionais e optamos por entendê-los em registro afim à tese da mútua constituição. Encaixes, em formulação mais restritiva e relacionalmente mais radical, são aqui definidos como sedimentações institucionais de processos de interação socioestatal que ganham vida própria (artefatos: instrumentos, regras, leis, programas, instâncias, órgãos) e mediante as quais atores sociais são, em alguma medida, bem-sucedidos em dirigir de modo contínuo a seletividade das instituições políticas ao seu favor, ampliando sua capacidade de agir. Fit admite em inglês o sentido de substantivo (encaixe) e de verbo (encaixar), pelo que essa dupla conotação evita eliminar a agência dos atores e conceder demasiada fixidez ao encaixe como instituição, pois o encaixe seria simultaneamente "o encaixar", ${ }^{8}$ um processo em construção contínua que supõe ação e atores. Ao definir o encaixe como uma sedimentação institucional

8 Agradecemos expressamente a Rebecca Abers por nos chamar a atenção para esse ponto. 
atentamos para esta dupla conotação, ele é simultaneamente o resultado de processos de interação e uma criatura ou artefato institucional que adquire densidade própria.

Privilegiar uma concepção não contextualista dos encaixes não equivale a propor que tudo o que importa no fenômeno da institucionalização é endógeno aos correspondentes processos de interação socioestatal - nem é isso que aqui postulamos. Constrangimentos e oportunidades exógenos ou contextuais existem, mas os ganhos analíticos de defini-los como encaixes são menos potentes, atentando para o fato de o contexto institucional maior importar na definição das estratégias dos MSs e das OSCs, bem como nos seus resultados. Alternativamente, a definição de encaixe como sedimentação institucional de processo de interação socioestatal outorga centralidade a constrangimentos e oportunidades endógenos a esse processo, bem como aos atores nele engajados, apontando os rumos a serem seguidos pela indagação empírica.

A rigor, e partindo do pressuposto da mútua constituição, a diferença entre constrangimentos e oportunidades exógenos e endógenos não é, para nós, de natureza ontológica, mas metodológica quanto ao foco de observação e fenomenológica quanto à percepção dos atores. Assim, regras definidas no nível federal operam como contexto das possibilidades de ação dos atores no nível municipal, mas elas próprias são produto de processos de interação socioestatal que envolvem outros atores agindo nessa escala. $\mathrm{Na}$ medida em que o processo de interações socioestatais focado se restrinja ao plano local e/ou a uma determinada política, outros processos e seus resultados em outros níveis federativos e/ou em outros setores de políticas são passíveis de definição como "contexto" em decorrência de uma opção metodológica e não pelas suas qualidades ontologicamente distintas. Por sua vez, os resultados desses outros processos são percebidos e vividos pelos atores como limites à sua atuação. Ainda assim, conforme será visto, parece 
mais pertinente "flagrar" o "contexto" em operação nos processos socioestatais como mecanismo interveniente do que como um fator constante pairando sobre a ação dos atores.

Isso posto, e conforme explicitado na seção inicial, encaixes variam horizontal e verticalmente, ou seja, quanto a suas especificidades e à hierarquia de autoridade em que operam. Canais de transmissão de informação, instâncias de fiscalização, cogestão de serviços, criação de programas ou políticas públicas, e inclusive a ocupação de cargos, podem ser, em processos de interação socioestatais, tanto encaixes arquitetados pelos atores sociais quanto capacidades adquiridas de atuação pelo Estado, mas possuem características e implicações políticas consideravelmente diferentes. A variação horizontal e vertical dos encaixes demanda, assim, maior especificação analítica. Mais: a articulação de diversos encaixes pode trazer consigo configurações emergentes de interação socioestatal que operam conectando diversos encaixes, com alguma estabilidade, em altitudes ou níveis de hierarquia diferentes, ou seja, com maior ou menor alcance político. Levar em consideração a articulação vertical e horizontal dos encaixes é relevante precisamente porque permite diferenciar quando operam configurações de encaixes de maior alcance e potência (domínios de agência) e quando se trata simplesmente encaixes avulsos ou em alguma medida desarticulados entre si.

Como sedimentações institucionais e produtos de processos de interações socioestatais, encaixes favorecem a agência dos atores sociais diretamente engajados nesse processo e daqueles que com eles guardam semelhanças funcionais e organizacionais. Assim, a forma organizacional sindicato é privilegiada pela legislação trabalhista, e não apenas os atores específicos que na história do sindicalismo conquistaram reconhecimento estatal. Encaixes, nesse sentido, são sedimentações institucionais de índole pública e, uma vez produzidas, não garantem controle exclusivo aos atores que as produziram. Assim, encaixes conferem alguma agência com 
certa duração a determinados tipos de atores, e não apenas àqueles diretamente envolvidos no processo de institucionalização. Leis, regulações, cargos e cadeiras ou vagas, órgãos e organismos, técnicas e instrumentos de políticas podem ser encaixes quando emergem como sedimentações institucionais de interações socioestatais e "fazem" os atores agir. Nem toda disposição legal, cargo, órgão ou instrumento de políticas constitui um encaixe. Por sua vez, nem toda conquista das OSCs ou dos MSs constitui encaixes, pois os últimos alongam no tempo a capacidade de influência dos atores concedendo-lhes alguma vantagem e algum grau de agência.

Arquitetar encaixes institucionais é conveniente para os movimentos sociais porque resguarda interesses e capacidade de (re)ação ao reduzir a contingência. Embora pareça contraintuitivo, encaixes operando em níveis de menor alcance político não são necessariamente menos institucionalizados do que configurações de encaixes inscritas em planos mais elevados. Por exemplo, uma peculiaridade dos instrumentos de políticas é que são modos de resolver certos problemas, aplicados de modo recorrente e sancionados como modos de proceder corretos (Lascoumes e Le Galès, 2007). Assim, um instrumento de políticas como um cadastro pode sobreviver como recurso "técnico" à despeito das mudanças de governo e de dinâmicas políticas gerais. Contudo, encaixes de altitude política elevada são especialmente valiosos para os atores coletivos, pois quanto maior o nível de autoridade em que ocorre a institucionalização, menor a contingência dos interesses resguardados pela mesma. Igualmente, a disposição de um número maior de encaixes articulados entre si é mais valiosa, do ponto de vista dos atores, do que a existência de um número menor de encaixes avulsos. A combinação entre um número maior de encaixes institucionais articulados entre si e sua inscrição em níveis de autoridade mais elevados é conveniente para os movimentos sociais, precisamente, porque resguarda seus interesses da contingência e poupa os atores de ter que disputar novamente amanhã as batalhas 
vencidas hoje. Afinal, instituições são decisões políticas congeladas no tempo (March e Olsen, 1984). Certamente, institucionalização não elimina o conflito nem salvaguarda definitivamente os interesses dos movimentos engajados em processos de interação socioestatal, mas desloca a disputa para um terreno relativamente mais favorável.

A articulação vertical e horizontal de conjuntos de encaixes perfila configurações variáveis e define uma propriedade básica dos domínios de agência. Domínios constituem esferas de competência e, neste caso, a competência diz respeito à capacidade de agir em determinado âmbito sob responsabilidade direta ou indireta do Estado, notadamente em campos de políticas sociais (Gurza Lavalle, Houtzager e Castello, 2012). Assistência social é, por exemplo, domínio de agência não apenas tradicional, mas centenário se considerada sua evolução a partir de benemerência e da filantropia (Gutirerres, 2015). Aos atores desse domínio reconheceu-se tradicionalmente a legitimidade para agir na intermediação de recursos públicos no atendimento de segmentos da população demarcados por determinadas vulnerabilidades. Instrumentos foram criados para viabilizar essa atuação, canais de comunicação foram definidos e mecanismos de certificação do trabalho desses atores foram criados. Sem dúvida, no Brasil pós-transição a multiplicação de domínios de agência mais notória corresponde à área de saúde, nos campos da atenção básica, da saúde da população negra, da política de HIV/Aids, do ensino e pesquisa da medicina social, para mencionar apenas alguns exemplos da área. Contudo, o pós-transição trouxe no seu bojo diversos processos de interação em que outros MSs como o feminista, ambientalista, de moradia, dos novos migrantes, negro, LGBT ou indígena avançaram no sentido da institucionalização, em alguns casos configurando domínios de agência.

Domínios de agência são configurações de encaixes institucionais articulados vertical e horizontalmente que favorecem a 
capacidade de agir de certos atores coletivos. Favorecem-nos porque: (i) implicam o reconhecimento de que os atores tem legitimidade para agir e demandar em nome de grupos específicos ou interesses difusos (embora não concedam monopólios na representação); (ii) selecionam e processam com maior frequência problemas e demandas relevantes para esses atores (ainda que com eles não definam uma relação de exclusividade); (iii) outorgam suporte material - organizacional ou financeiro - aos atores propiciando sua estabilização (ainda que não garantam financiamento permanente); e (iv) reduzem o poder de concorrência de atores estranhos ao domínio de agência (mesmo que não entreguem aos atores favorecidos o controle sobre as barreiras de entrada). Trata-se de domínios de agência porque institucionalizam âmbitos de atuação que animam a capacidade de ação dos atores, "fazem-nos" agir estimulado sua condição de agentes. Por outras palavras, são domínios de agência porque neles se reconhece e favorece a capacidade de agir e decidir de determinados atores - ênfase que em inglês poderia ser mais intuitivamente percebida sob a formulação domains of agency, diferente de agency domains. A ideia de "domínios", por sinal, é comum na literatura especializada em políticas públicas, não raro focando as disputas e alianças dos atores em diferentes domínios de políticas (ver, por exemplo, Browne, 1990; Chambré e Fatt, 2002; Salisbury, Heinz, Laumann e Nelson, 1987; Knoke, 1993). A ênfase aqui é nos atores e na capacidade que eles têm de agir em relação aos processos de institucionalização; essa agência não necessariamente coincide com (ou se ordenam sob) a lógica setorial das políticas.

A abordagem de domínios de agência não é, prima facie, uma proposta normativa, na medida em que não assume que a institucionalização é "boa" a priori conforme algum parâmetro externo de avaliação, nem que os atores politicamente alavancados pela sua inscrição em determinado domínio atuem em prol do "bem comum" ou genuinamente em nome dos grupos sociais que 
invocam na sua mobilização, ou sequer que os encaixes serão apenas utilizados pelos MSs engajados diretamente na sua produção. Obviamente, MSs de orientações políticas as mais diversas podem se engajar em processos históricos de institucionalização de seus interesses e agendas no Estado. Pressupomos apenas que do ponto de vista dos MSs há benefícios associados à institucionalização e assumimos ser desejável que MSs tenham condições de vocalizar os conflitos sociais, de politizar questões de baixa notabilidade na agenda pública e de escolher as estratégias de ação que julgarem mais pertinentes para pressionar o Estado dentro do marco geral do respeito aos direitos humanos.

\section{Breve consideração metodológica: processos, causas, efeitos e mecanismos}

Em termos metodológicos, a abordagem de domínios de agência torna endógenos aos processos de interação socioestatal fatores que comumente figuram, nas explicações causais, ora como contexto externo ora como variáveis independentes - oportunidades e restrições políticas, capacidades estatais, repertórios de ação e identidades, alianças pluriclassistas, recursos organizacionais, entre outras. De índole processual, a abordagem de domínio de agência substitui o enfoque contextual e exógeno pelo enfoque dinâmico e relacional dos processos políticos, cujas condições são apreendidas como mecanismo simultaneamente produtor e produto das interações socioestatais. Conquanto os mecanismos por definição tenham efeitos recorrentes nos processos políticos, suas consequências ao longo do tempo variam consideravelmente dependendo das condições iniciais e das combinações com outros mecanismos (Tilly, 2001). Ademais, as condições que incidem sobre processos políticos devem ser examinadas em associação entre si, pois os mecanismos intervenientes na interação socioestatal ao mesmo tempo em que contribuem na construção de encaixes e 
configurações de encaixes são por eles produzidos - inócuo estabelecer causas primas.

Encaixes institucionais e a eventual construção de domínios de agência são produtos do processo de interação socioestatal que potencializam a agência de atores sociais, cuja reconstrução e resultados demandam uma agenda de pesquisa. Em outras palavras, pela abordagem do domínio de agência é esperado que a institucionalização seja propicia a agência de MSs e OSCs, pois institucionalização diz respeito à disposição de condições comparativamente mais favoráveis que lhes propiciam agir em face do Estado e de outros atores sociais e privados; entretanto, diagnosticar sua ocorrência e implicações é tarefa da pesquisa empírica.

Assim, não são postuladas relações causais gerais no que diz respeito aos resultados de se arquitetar encaixes e se construir domínios de agência, mas mecanismos, enquanto regularidades associadas aos processos de causação, guardam aqui afinidade com uma abordagem processual - como a do domínio de agência. Encaixes arquitetados pelos atores no Estado e domínios de agência que conferem legitimidade de agir e poder de influência na política e no processo de decisão são construções históricas contingentes e não fatalidades. Mecanismos intervêm, de modo isolado ou em combinação com outros mecanismos, nos processos de interação e alteram os modos e as chances da institucionalização - ao mesmo tempo em que são por eles afetados. É tarefa do escrutínio empírico em profundidade dos processos de construção de encaixes por atores sociais, desde sua gênese até sua eventual consolidação institucional em domínios de agência, identificar mecanismos específicos operando quer nas especificidades ou feições dos encaixes (variação horizontal) quer em sua hierarquia política ou autoridade (variação vertical) ou na sua articulação sob determinadas configurações (domínios de agência).

Grosso modo, e apenas à guisa de consideração metodológica, é possível sugerir a busca de três tipos de mecanismos, a saber, 
mecanismos institucionais, mecanismos relacionais e mecanismos sociais. Os mecanismos institucionais consistem em condições que afetam as instituições políticas visadas na formação de encaixes, a exemplo da permeabilidade do Estado, da composição partidária e eleitoral dos poderes legislativos e executivo, e das capacidades estatais. A permeabilidade do Estado, enquanto conjunto de instituições e atores heterogêneos, opera sobre a incidência das OSCs e MSs nas políticas públicas. O grau de porosidade do Estado às demandas dos atores coletivos, e a associação dos últimos a alianças partidárias e eleitorais, favorecem a construção de encaixes na burocracia estatal. As capacidades estatais no provimento de normativas legais, recursos administrativos, humanos e financeiros voltados a operar a política são igualmente mecanismos intervenientes na construção de encaixes institucionais, pois exprimem a acessibilidade ao e a competência do Estado para operar setores e aspectos específicos da política pública. Ainda que encaixes instituídos possam se articular a outros encaixes e consolidar em domínios de agência, as capacidades do Estado na política afetam a amplitude da influência dos atores sociais no processo decisório.

Os mecanismos relacionais correspondem a estrutura de vínculos das OSCs e MSs com sua rede de relações informais e sua rede de apoiadores e coalizões, ao longo do tempo. Isso inclui as redes de ativismo do movimento e de articulação dos atores sociais e organizacionais na defesa de demandas compartilhadas em relação a determinado setor de política, bem como as alianças ou coalizões com instituições do executivo, legislativo e do sistema de justiça, partidárias, religiosas e organismos internacionais - constituídas ao longo do tempo frente a oportunidades de influir no processo político. Em processos de interação socioestatal, a formação de redes de movimento e de redes de apoiadores, o papel de intermediação, coordenação e articulação de brokers, potencializam a influência dos atores coletivos na política pública, condicionando a construção de domínios de agência. 
Por fim, os mecanismos sociais correspondem às capacidades de ação dos atores das OSCs e MSs para arquitetar encaixes institucionais e construir domínios de agência. Em geral, são expressas nas formas organizacionais e nos repertórios de ação coletiva acionados nos processos de interação com o Estado, incluso formatos mais formalizados, especializados e profissionalizados de organizações de movimentos e de associações civis. As capacidades de agir revelam o aprendizado dos atores sociais, sua expertise e saber para operar políticas específicas, atuar como incubadores de instrumentos de políticas e interagir com o modus operandi da administração pública, sendo igualmente forjadas em processos pretéritos de interação socioestatal e de institucionalização.

Nos processos históricos de institucionalização - conduzam ou não a domínios de agência -, os mecanismos são interdependentes e complementares na construção de encaixes com vistas à incidência nas políticas. Entretanto, e conforme dito, conquanto cruciais, os mecanismos não devem ser concebidos como determinantes causais e sua ausência como impeditiva apriorística da construção de encaixes. Isso pois, as condições que favorecem a amplitude de influência dos atores nas decisões políticas e sua conversão em domínios de agência podem ser forjadas no processo mesmo de interação com o Estado e as instituições. Consonante ao pressuposto de mútua constituição entre Estado e sociedade civil, mecanismos, sejam eles institucionais, relacionais, sociais ou de outra possível índole, tanto condicionam processos de institucionalização, enquanto herança de interações socioestatais pretéritas, quanto são ensejados por esses últimos quando a institucionalização em foco gera encaixes que, como artefatos, aparecem como condição da ação ulterior de outros atores coletivos. Assim, a construção de encaixes e sua ativação ao longo do tempo guarda relação com o desenvolvimento de capacidades organizacionais dos atores sociais, por exemplo, mediante a complexificação organizacional das OSCs e MSs (via a gestão de programas e projetos governa- 
mentais, e a ocupação de cargos por ativistas, por exemplo) ou mediante a produção de condições propícias para a formação de redes de recrutamento e/ou de apoiadores, de articulações e coalizões de defesa de causas, ou, até mesmo, para a emergência de novas organizações dedicadas a articulação de redes (encontros, fóruns, comissões, conferências, conselhos e grupos de trabalho). Encaixes institucionais e domínios de agência, conforme será mostrado a seguir, também guardam relação com construção de capacidades estatais, criando ou ampliando-as, por exemplo, mediante inovação ou experimentação socioestatal em instrumentos de políticas, criação de órgãos, adoção de categorias cognitivas ou desenvolvimento de habilidades específicas em segmentos das burocracias.

\section{Do outro "lado": as capacidades do Estado}

O diálogo até aqui empreendido com perspectivas realistas, diálogo de tom crítico com o pluralismo e revisionista com o neocorporativismo, inspirou os delineamentos da noção de domínio de agência. Já as implicações analíticas (subteorizadas, como vimos) da agenda do neo-institucionalismo histórico nos legaram, pari passu a noção de encaixes institucionais, uma apreensão radicalmente relacional das dinâmicas pelas quais valores, interesses e reclamos das OSCs e dos MSs tendem a e podem ser cristalizados em instituições. Vamos, por fim, dispor em linha de continuidade argumentativa com as noções de domínio de agência e encaixes institucionais a noção de capacidade estatal, posicionada como componente analítico-descritivo incontornável na compreensão das chances de acesso e sucesso institucional quanto à vocalização dos atores não estatais. Trata-se, aqui, de uma implicação cognitiva: a uma lógica explicativa focada nas interações socioestatais corresponde um descentramento que leve em consideração o “outro lado" das equações socioestatais, com fins a determinar qual o papel do componente estatal naquelas interações. Para explicar 
tal descentramento dedicado às capacidades estatais voltemo-nos, primeiramente, a uma definição de capacidade estatal (definição provisória e não institucionalista, porém útil mais adiante) para passar, em seguida, à trajetória ocupada pela State capacity no neo-institucionalismo histórico, de suas raízes às posteriores gerações, nuances e inflexões.

Em sua definição mais enxuta, capacidade estatal pode ser entendida como "a competência (ability) dos Estados de formular e implementar políticas” (Kjaer et al., 2002, p. 20). Já na grade da contentious politics, capacidade estatal designa "o grau de controle que os agentes estatais exercem sobre pessoas, atividades e recursos no âmbito da jurisdição territorial do seu governo. Quando aumenta a capacidade estatal", dizem McAdam et al. (2004, p. 78), "isso se dá através de quatro processos, em geral, complementares: a substituição de um governo indireto por um direto; a penetração por Estados centrais em periferias geográficas; a padronização de práticas e identidade estatais, e a instrumentação - [isto é, o] crescimento dos meios de execução das políticas pretendidas" (destaques no original). Notem-se aí diferenças de registro entre o que o Estado faz e como o faz. A primeira definição aglutina ambos os registros: como faz (sua competência) e o que faz (formula políticas e as implementa). Na definição de McAdam, Tarrow e Tilly ganha-se em especificação: o "como" da ação estatal entra em cena, em especial, com a noção de "instrumentação", sendo que em nível conceitual mais amplo importa "o que" o Estado faz, isto é, seus "graus de controle". Foi esta última acepção de capacidade estatal que, primeiramente, ocupou o centro heurístico das obras, não do neo-institucionalismo histórico, mas daquela corrente que ao lado de J.P. Nettl foi uma de suas matrizes intelectuais, qual seja: a produção da sociologia histórica de meados dos 1970 - não por acaso, disparada por Tilly e Skocpol.

A crítica a explicações de cunho societal ou de tom modernizante sobre o então chamado "desenvolvimento político" levou 
C. Tilly e outros (1975) a perscrutar os processos sociopolíticos na gênese dos Estados modernos. "[Nosso] viés [de análise]", diz Tilly (1975a, p. 6), "foi deliberado. A especificação da organização das forças armadas, da taxação, do policiamento, do controle do fornecimento de alimentos e da formação de pessoal técnico põe em relevo atividades que foram difíceis, custosas e, não raro, indesejadas por grande parte da população". Tais "atividades" são competências estatais historicamente disputadas e construídas vis- $\dot{a}$-vis populações locais, em geral, malgrado estas últimas. A gênese e a sobrevivência, ou não, dessas atividades de controle e extração - de recursos humanos, materiais e naturais - variaram histórica e culturalmente, mas os elementos que compuseram a equação fundamental dos processos de State-building foram três. "Primeiro, há a população que leva alguma vida política coletiva [...]. Em segundo, há uma organização governamental que exerce controle sobre os principais meios de coerção da população. Em terceiro, há relações rotinizadas entre a organização governamental e a população" (Tilly, 1975a, p. 32). No meio dessa equação, e como resultado da interação entre esses elementos, foram negociados e produzidos direitos que transformaram súditos em cidadãos. Em versão mais recente, Tilly (1996 [1990]) aprofundou o argumento segundo o qual os tipos de direitos tanto produzem como seguem a ampliação da capacidade de atuação estatal frente às demandas e barganhas com parcelas expressivas das populações. Aquelas "relações rotinizadas" passaram a ocupar, nesse argumento, o centro do que hoje chamamos de "cidadania", "[que] consiste de múltiplas negociações elaboradas pelos governantes e estabelecidas no curso de suas lutas pelos meios de ação do Estado, principalmente pela guerra" (Tilly, 1996, p. 164).

Se a guerra ocupou lugar central nos macrodiagnósticos de construção de Estados, ela esteve desde sempre vinculada e remetida a outras capacidades estatais naquele naipe de explicações. Exemplo disso pode ser visto na clássica análise de T. Skocpol que, 
antes mesmo de reivindicar "o Estado de volta à cena”, insistia que "a vontade e a capacidade dos Estados para levar adiante mudanças econômicas nacionais são influenciadas pela sua situação militar e pelas pré-existentes capacidades políticas e administrativas militarmente relevantes" (1979, p. 22; destaque nosso). De forma original nas análises de grandes revoluções, Skocpol enfatizou o componente das organizações de Estado, lançando luz sobre os conflitos (fossem eles internacionais, internos à sociedade política ou domésticos com a população) e somando-as ao rol de explicações que tendiam a resumir tais revoluções a dinâmicas societais. Assim, enquanto para outras chaves as causas básicas de "crise do Antigo Regime" seriam relativas à perda de legitimidade, surto modernizador ou renovação de dominação de classe, explicações como as de Skocpol e as de Tilly (2003), centradas no Estado, enfatizam graus de controle estatal, bem como as crises neles ocorridas quanto a dinâmicas de reprodução institucional - crises na taxação ou no emprego da força repressiva, por exemplo. "Em outras palavras, as práticas e estruturas estatais importam para a formação mesma de movimentos revolucionários bem como para seu destino subsequente" (Goodwin, 2003, p. 410).

Constante embora discreta, a noção de capacidade estatal atravessou gerações e agendas de pesquisa. Na primeira metade dos anos 1980, a afirmação de que "o Estado importa” insistia no fato de que o Estado não deveria ser entendido como mero contexto para disputas quer entre classes ou grupos. Interessantemente, tanto na reconstrução hercúlea de M. Mann como no programa de Bringing the State Back In, o sentido da crítica a explicações políticas por variáveis extrainstitucionais assumiu tom weberiano. Estados são definidos "como organizações que reivindicam o controle sobre territórios e pessoas e que podem formular e perseguir objetivos que não são simplesmente reflexos das demandas ou interesses de grupos sociais, de classes ou da sociedade. Isto é o que geralmente se entende por 'autonomia do Estado'” (Skocpol, 1985, p. 9). 
Igualmente, tanto no registro de Mann como no de Skocpol, Evans e Rueschemeyer se dá uma espécie impensada de sinonimização entre autonomia do Estado e capacidades estatais. "A explicação das capacidades estatais", diz Skocpol, "está fortemente ligada à explicação da formação de objetivos autônomos pelo Estado" (1985, p. 16). ${ }^{9}$ Noutro registro, porém de lógica análoga, as principais formas de poder estatal, tal como pensadas por Mann, são capacidades, ${ }^{10}$ mais que sinonimizadas, dissolvidas na noção de autonomia "A autonomia do Estado, tanto da forma despótica como da infraestrutural, decorre principalmente da competência única do Estado de fornecer uma forma de organização territorialmente centralizada" (Mann, 1984, p. 185; destaque no original).

Respondendo a uma lógica de debate intelectual com e contra interpretações marxistas e pluralistas, a veia enfática do neo-institucionalismo sobre a autonomia do Estado rendeu efeitos frutíferos (Skocpol, 1995). Trouxe explicitamente consigo a noção de capacidade estatal para o núcleo heurístico de sua agenda - "as capacidades do Estado de implementar estratégias e políticas merecem análise detalhada por direito próprio" (Skocpol, 1985, p. 16) - levando-a a outros diapasões, sendo afiançada mesmo pelo institucionalismo à la escolha racional. ${ }^{11}$ Além disso,

9 À conclusão, P. Evans, D. Rueschemeyer e T. Skocpol diziam que "junto das táticas analíticas para investigar as capacidades do Estado, os ensaios aqui coletados também oferecem idéias sugestivas e novas questões sobre a dinâmica da autonomia estatal" (destaque no original) (1985, p. 353).

${ }^{10}$ Cf. "Podemos denominar esse poder infraestrutural, [como] a capacidade do Estado de penetrar na sociedade civil e implementar decisões políticas logisticamente ao longo do território" (Mann, 1984, p. 189; destaque no original). Devido a essa espécie de dissolução da capacidade estatal na noção de autonomia, não há, neste primeiro M. Mann (1984), um raciocínio iterativo, mas sim extrativo, no qual o Estado extrai recursos da sociedade civil para fortalecer capacidades suas. Como veremos adiante, no entanto, a lógica subjacente à noção de poder infraestrutural muda relacionalmente em Mann tornando-se um raciocício de "mão dupla" (Mann, 1993, p. 59).

11 Também no registro da rational choice parece ter operado a sinonímia capacidadesautonomia. "A capacidade de implementar políticas iniciadas pelo Estado [state-initiated policies, no original]", diz B. Geddes, "depende da competência 
essa postura State-centered não levou necessariamente a uma reificação do Estado; correspondeu, antes, a uma lógica iterativa de análise na qual as relações Estado/atores não estatais pesam sobre as preferências destes últimos; "os significados da vida pública e as formas coletivas por meio das quais os grupos tomam consciência dos objetivos políticos e o trabalho para alcançá-los surgem, não apenas das sociedades, mas nos pontos de encontro de Estados e sociedades" (1985, p. 27).

Autocriticada, essa agenda operou relevantes deslocamentos analíticos que, além de terem dado enraizamento sociopolítico à noção de autonomia (Cf. Evans, 1995), estão bem sintetizados na passagem de um paradigma "State-centered" para outro "polity-centered". ${ }^{12}$ Se essa inflexão operada por Skocpol (1992) legou uma noção como a de encaixes, deu também continuidade àquela posição, discreta, ${ }^{13}$ ocupada pela noção de capacidade estatal no neo-institucionalismo histórico. Caso exemplar dessa continuidade pode ser visto na análise de The People's Lobby (Clemens, 1997), a respeito da mobilização de associações voluntárias nos Estados Unidos de fins do XIX e início do XX. Aí E. Clemens se dedica às interações travadas por organizações de fazendeiros, de trabalhadores e de mulheres com subpartes do governo estadunidense sublinhando efeitos político-institucionais nada

para tributar, coagir e moldar os incentivos que encaram os atores privados [...]. Se se quer entender os Estados como atores, é preciso olhar para suas entranhas burocráticas" (1994, p. 14).

12 Ver "A Polity-Centered Analysis of American Social Provision" (Skocpol, 1992, p. 41 e ss.). Confira ainda: o termo State-centered "tem sido muitas vezes interpretado como 'determinismo burocrático, que nunca defendi. Igualmente importante, quero enfatizar que vários aspectos da política e das interações Estado/sociedade estão incluídos no meu quadro analítico de referência” (Skocpol, 1992, nota 90).

13 Cabe notar que o argumento analítico mais fino de Skocpol remonta a Lowi (1972) - diz ela: "assim como a política cria políticas públicas, também as políticas refazem a política" (Skocpol, 1992, p. 58). Interessante que, a despeito de mencionar 'capacities' e 'capabilities' em seu argumento (idem), Skocpol não aprofunda teoricamente a reflexão sobre a função desempenhada pelas capacidades na recriação de políticas. 
desprezíveis. O primeiro desses efeitos (1997, p. 27) foi o incremento e a racionalização ocorridos na capacidade do Estado norte-americano que passou por dinâmicas duradouras de inovação organizacional. Outro efeito daquelas interações foi a ampliação das formas e espaços de representação de interesses para além das tradicionais estruturas partidárias, inaugurando a "política do pluralismo" naquele país. Portanto, longe de encarnar uma espécie de natureza excepcional própria à sociedade estadunidense, o pluralismo constitui um padrão global de interação socioestatal historicamente produzido e disputado. Com e contra Skocpol (1992) e Skowronek (1982), Clemens remeteu o pluralismo à trajetória das interações concretas de um conjunto de atores e atrizes não estatais, cujas preferências e identidades foram moldadas por regras dadas, embora tenham se valido delas mesmas para transformar organizacionalmente, e em chave de representação extracongressual, a capacidade estatal daquele país.

O debate up to date sobre capacidades estatais se afastou da lógica inicial que marcou os neo-institucionalistas, da afirmação de que "o Estado importa" e da defesa enfática de sua autonomia. Agora, são as feições conceitual-metodológicas, bem como a superação da sinonímia entre autonomia e capacidades, ${ }^{14}$ que animam o debate. $\mathrm{O}$ objetivo de conceitualizar o que designa e distingue analiticamente a noção de capacidade estatal, além do problema de como mensurá-la, é visível em vários esforços recentes. "The state of State capacity", "Conceptualizing State capacity" e "State capacity as power: a conceptual framework", respectivamente de Kjaer et al. (2002), de Cingolani (2013), e de Lindvall e Teorell (2017),

14 Cf. "Nossa definição de capacidade estatal ajuda a esclarecer a distinção comumente borrada entre capacidade e autonomia estatais [...]. Em nossa opinião, as categorias analíticas de autonomia e capacidade precisam ser separadas. [...] O aparelho de Estado pode ser submetido ao mesmo critério duplo: sua autonomia reflete a medida em que não é controlado por forças externas; [já] sua capacidade reflete a medida em que ele [o aparelho] controla os resultados que tenta alcançar" (Lindvall e Teorell, 2017, p. 10; destaques no original). 
são títulos que buscam discernir condiçôes externas e componentes internos às capacidades, situando conjuntos de fatores a elas ligados e propondo alternativas metodológicas para sua mensuração. Uma saída possível proposta para a análise de capacidades estatais é oferecida por Cingolani (2013, p. 36) que distribui seis "fatores" ou tipos de capacidade em três dimensões: (a) dimensão administrativa (tipos administrativo, comercial e de alcance territorial); (b) dimensão extrativa (taxação fiscal e de bens e serviços); e (c) dimensão de poder coercitivo (relativa ao potencial coercitivo).

Não por acaso, o debate contemporâneo ecoou na agenda brasileira e ganhou novos contornos. Em sua comparação de oito arranjos de políticas públicas, R. Pires e A. Gomide (2016) propõem a diferenciação entre capacidades técnico-administrativas e capacidades político-relacionais, de modo a testar a associação positiva entre inovação e presença destas últimas. Se não surpreende o resultado positivo por eles encontrado na correlação entre capacidade administrativa e entrega de produtos, instiga o achado segundo o qual um baixo nível de inovação está correlacionado à ausência tanto de mecanismos de participação como de presença de agentes políticos (2016, p. 138) - ambos componentes da definição de capacidade político-relacional. Além desse achado e dessa diferenciação analítica, tal proposta importa também por colocar as interações entre Estado e atores não estatais no centro da análise. Nessa mesma veia, Pereira (2014) analisou atores e fatores em jogo na construção de Belo Monte, também propondo uma diferenciação interna à noção de capacidades estatais, entre suas dimensões participativa, decisória e de coordenação interburocrática (2014, pp. 48 e ss.). Para ela, assim como para nós, "a influência de atores sociais nas decisões estatais de políticas prioritárias depende, em grande medida, não apenas da mobilização dos grupos sociais, mas das capacidades estatais" (Pereira, 2014, p. 230).

Diretamente inspirados nas inflexões do neo-institucionalismo histórico e na interlocução com a produção de Abers e 
Keck (2013), Pereira (2014), Pires e Gomide (2016) e Bichir et al. (2017), defendemos que a capacidade estatal é fator fundamental para as dinâmicas de institucionalização dos interesses e demandas dos MSs e das OSCs. Pode-se dizer que a capacidade estatal opera como uma sorte de bússola não mecânica da ação coletiva - agir com ou contra o Estado, ou agir de qualquer outro modo, leva em conta o acúmulo (ou a falta) de capacidade instalada relativamente a uma política específica na medida em que, e porque, o destino institucional duma preferência determinada também varia conforme a capacidade instalada. Por exemplo: não raro, OSCs e MSs fazem as vezes de Estado desempenhando competências e funções organizacionais, ${ }^{15}$ como nos casos de controle ou distribuição, não dominadas por agências do Executivo. Como uma espécie de guia, é a medida (acúmulo ou falta relativa) de capacidade instalada que orienta, não de forma mecânica, a ação de atores não estatais. Assim, ao mesmo tempo em que os interesses dos atores da sociedade civil são moldados, seja à distância ou diretamente, pela capacidade acumulada (ou pela falta dela) num subcampo específico de política pública, esses atores não estatais são eles próprios estruturadores de capacidades por meio das interações socioestatais.

Como vimos, a posição mesma ocupada pela capacidade estatal varia em diferentes gerações e casos analisados: ela designa "graus de controle" sobre o território e os recursos físicos e humanos

15 Aqui, o deslocamento operado no raciocício do segundo M. Mann $(1993 ; 2008)$ nos é particularmente útil. "Poder infraestrutural é uma via de mão dupla: ele também permite a partes da sociedade civil controlar o Estado" (1993, p. 59); é, então, neste sentido de "mão dupla" que nossas interlocutoras, inspiradas em Mann, se aproximam de nosso argumento. "Se o poder infraestrutural permite ao Estado expandir seu controle sobre o território operando através de organizações não estatais, isto também abre espaço para essas organizações influenciarem o Estado" (Abers, Oliveira e Pereira, 2017, p. 859; destaque nosso). Nessa mesma linha, veja-se ainda, Bichir et al. que defendem a relevância de "considerar [na análise] a balança entre capacidades desenvolvidas pelos agentes de Estado e capacidades acumuladas por OSCs envolvidas no processo de políticas públicas" (2017, nota 5; tradução nossa). 
da população na estruturação dos Estados-Nação, assim como sua falta opera como mola propulsora de movimentos revolucionários, ao passo que ela é incrementada nos e pelos pontos de encontro com atores e atrizes não estatais, como mostraram Skocpol e Clemens. Histórica e empiricamente, as capacidades variam; já analiticamente a capacidade estatal pode e deve ser tratada como um modulador da institucionalização.

Considerar as capacidades estatais como variável fundamental dos processos sociopolíticos que pretendemos explicar pode soar uma afirmação limitada se retirada dum registro radicalmente relacional de cognição. As propostas de diferenciação analítica feitas por pesquisadores conterrâneos são bem-vindas nesse sentido porquanto inspiradoras e interlocutoras prementes de nosso raciocínio. No entanto, outras definições de state capacity, especialmente anglo-saxãs, reproduzem um tipo de raciocínio estatista que criticamos: a capacidade estatal, dizem Lindvall e Teorell (2017, p. 10), "reflete a medida em que o aparelho de Estado controla os resultados que tenta alcançar"; em chave análoga, B. Geddes (1994, p. 14) a considera como "capacidade de implementar políticas iniciadas pelo Estado”. Ora, tal como os resultados de uma política pública específica não são perseguidos e almejados apenas por atores estatais (sendo vantajosos para alguns atores sociais e desvantajosos para outros, visados e contestados por uns e por outros), também a gênese dos meios de implementação de tal ou qual política não está sobretudo, nem exclusivamente, dentro das instituições. Desde a concepção duma política pública, da sua formulação às suas execução e avaliação, o complexo dos instrumentos e modos pelos quais o Estado faz o que faz e como o faz está, antes, nas conexões de atores do Estado com atores de fora dele, mas em constante relação com ele, nomeadamente, nas interações com organizações da sociedade civil e movimentos sociais, enfim, nas interações socioestatais. Ou, como diz Pereira (2014) 
inspirada em E. Marques, esse complexo de formas de atuação e intervenção estatal se enraíza concretamente em "redes transversais" ao Estado, isto é, nas redes que aproximam ou afastam atores não estatais de atores estatais. Algo que o próprio Marques (2006) chama com argúcia de tecido do Estado e fábrica relacional do Estado.

A nosso ver, portanto, a noção de capacidades estatais merece entrar conceitualmente para o panteão dos fatores que pesam nas equações, cálculos e interações que animam movimentos sociais, seus resultados institucionais e suas análises. Sua apreensão relacional permite dizer que tende a operar em duplo nível: a capacidade estatal tanto molda as chances e estratégias de acesso e sucesso de interesses e demandas das OSCs e dos MSs, como é moldada e incrementada pela interação desses últimos atores com instituições e atores do Estado. Embora sua função concretamente desempenhada quanto às demandas civis não possa ser predita, as capacidades são parte estruturante das lógicas de institucionalização e por elas estruturadas. Incorporar as capacidades em nossos esquemas explicativos exige, em um nível, o escrutínio das capacidades acumuladas nos e pelos arranjos governamentais e institucionais de distintos naipes - ministérios, gabinetes, corpos magistrados, meios de coerção, secretarias, câmaras, assembleias, etc. -, na medida mesma em que tais capacidades não apenas pesam sobre o destino institucional das demandas de MSs e OSCs, como também moldam estas últimas. Na conta das capacidades acumuladas poderia entrar, por exemplo, a diferenciação analítica oferecida por Pires e Gomide (2016), qual seja, capacidade político-relacional. Apenas para dar um exemplo: laços - seja com representantes eleitos ou nomeados em um órgão estatal específico, com atores partidários ou com especialistas de subcampo de política pública -, poderiam ser tomados como índice de capacidade político-relacional. Tais laços constituem índice adequado, pois refletem alianças ou portas para arranjos organizacionais que 
podem facilitar ou dificultar as interações com atores civis, e tendem a aumentar ou bloquear suas chances de acesso ao Estado e à cristalização de suas demandas e interesses.

Noutro nível, por fim, importa entender se, como e em que medida as interações socioestatais, pela via das categorias de "descrição" do mundo e tecnologias produzidas por MSs e OSCs, incrementam a capacidade instalada. Quer dizer, importa entender também em que medida, por via de seus discursos e saberes produzidos fora e dentro de suas relações com o Estado, atores não estatais interpelam os dispositivos oficiais de intervenção, classificação e ordenamento do território e da população. Trata-se, aqui, de chegar ao outro lado das equações socioestatais colocando em perspectiva a relação entre instrumentação e interação. É na instrumentação, ou seja, nos meios de concepção e execução das políticas "pretendidas" - no termo de McAdam, Tarrow e Tilly (2001) - que os atores não estatais podem ver seus interesses e categorias em jogo, pois a instrumentação é uma forma naturalizada em que opera a seletividade politicamente construída das instituições. Uma apreensão relacional dos instrumentos de políticas públicas requer a objetivação de sua gênese sociopolítica, especialmente considerando que os instrumentos, quando endógenos ao processo analisado, constituem encaixes. Para tal tarefa faz-se necessário escrutinar quais atores e condições entram em jogo, e quais demandas, interações e padrões de interação são erguidos, na incorporação e cristalização institucional de categorias e formas de intervenção que burocratas e agências governamentais, por meio e depois de interações continuadas, passam a utilizar e ver como "seus", como recursos da implementação de "suas" políticas pretendidas ou, como também pode ocorrer, como de políticas "compartilhadas" com partes da sociedade civil. Jamais lineares e desafeitos a etapismos, o chamado ciclo das políticas e, em particular, os processos de implementação tendem a desnortear a maior parte dos envolvidos: militantes não cansam de apontar os limites 
de tal ou qual política pública, enquanto burocratas elogiam a "participação" e analistas normativos endossam o coro militante. A nosso ver, a entrada da análise da gênese sociopolítica dos instrumentos de políticas públicas, e sua eventual conceituação como encaixes, como parte da agenda da institucionalização de demandas dos MSs e das OSCs, é passo necessário não só à compreensão do aumento das chances de acesso ao Estado ou da sua eventual diminuição, mas também para entender as capacidades de ação do próprio Estado.

\section{Dos movimentos, políticas e processos de interação contem- plados no livro}

Entender a institucionalização de demandas e recursos de atuação dos movimentos sociais no Estado é operação analítica nada trivial, conforme mostrado mediante o diálogo crítico com a literatura disponível. Contudo, a institucionalização das agendas de reivindicações dos movimentos sociais é fenômeno dos mais notáveis do Brasil pós-transição e não apenas demanda arcabouços analíticos propícios para orientar sua compreensão cabal, mas esforços coletivos de pesquisa capazes tanto de avançar diagnósticos empíricos sobre processos de institucionalização que carecem de conhecimento sistemático quanto de moldar as distinções analíticas aqui propostas às exigências da pesquisa, contribuindo para tornar mais denso o esforço de construção de teoria. Focando o período de pós-transição democrática, os capítulos do livro apresentados a seguir abordam uma diversidade de movimentos sociais e organizações de sociedade civil no Brasil e América Latina, retratados em diferentes contextos regionais e em três níveis federativos. Não obstante essa heterogeneidade, os textos analisam sistematicamente as interações dos MSs e das OSCs com o Estado, descortinando as suas instituições em algumas políticas setoriais, bem como mostrando suas transformações. 
O leitor poderá acompanhar os processos de institucionalização de médio alcance nas interações socioestatais envolvendo o movimento negro e o movimento municipalista de saúde, ambos no nível federal e nas últimas quatro décadas, o movimento popular urbano no estado do Espírito Santo, o movimento da criança e do adolescente na política socioeducativa em São Paulo, as OSCs atuantes na política migratória no estado e cidade de São Paulo, o movimento feminista negro e as OSCs vinculadas aos Wajãpi e suas reivindicações de políticas específicas para a saúde e, especificamente, para a epidemia de HIV/Aids, o movimento feminista e sua atuação nas políticas para as mulheres no século XXI no nível nacional. Por fim, o feminismo e a incorporação da ideia de "gênero" nas políticas públicas são retratados no caso paraguaio - caso com implicações analíticas potentes para entender o processo de construção das capacidades de ação do Estado. Embora esta última análise desvie a atenção para outro caso nacional, sua inserção se justifica tanto pela riqueza da reconstrução do processo de institucionalização da agenda de gênero em contexto político-cultural especialmente adverso, como por seu potencial para pensar em perspectiva comparada os avanços e limites dos feminismos latino-americanos e das institucionalizações da noção de "gênero".

O livro é composto por duas partes que organizam o alcance empírico das nossas pesquisas. $\mathrm{Na}$ primeira, intitulada "Movimentos e políticas sociais no Brasil pós-transição", encontram-se capítulos que empregam o arsenal analítico para analisar as interações socioestatais em algumas das políticas sociais, tais como saúde, política migratória, políticas urbanas e política socioeducativa. Na segunda parte, denominada "Movimentos, raça, gênero e políticas públicas" examinam-se movimentos e políticas sociais, mas com o foco específico nos movimentos negro e feminista; as questões de raça e de gênero são aí dimensões estruturadoras de políticas públicas. 
As partes do livro podem ser exploradas separadamente ou de modo integrado, pois ambas se complementam nas contribuições para o argumento geral acerca da abordagem de encaixes institucionais e domínios de agência. A primeira parte oferece panorama de como a abordagem pode ser útil à análise de processos de institucionalização e de interação socioestatal voltados à influência na agenda política e à incidência na política pública social. Considerando diferentes movimentos, políticas sociais setoriais e níveis de governo, os capítulos dessa parte analisam em profundidade por que e como movimentos sociais constroem historicamente encaixes institucionais e domínios de agências em processos de interação socioestatal voltados à institucionalização de demandas. Ao fazê-lo, reconstroem empiricamente seu caráter processual, dinâmico, relacional, contingente e histórico. Por seu turno, a segunda parte do livro aplica a abordagem de domínios de agência a políticas públicas a partir da interseccionalidade de gênero e raça. Esse diferencial enriquece as explicações seja da construção histórica de encaixes seja das configurações dos domínios de agência, seja ainda dos resultados da institucionalização nos atores e na política, pois demandas de raça e gênero tensionam noções universalistas presentes na edificação de parte das políticas setoriais de caráter social.

Abrindo a primeira parte do livro, o capítulo de autoria de Monika Dowbor parte de questão desafiante para os movimentos sociais. As reivindicações e os projetos de movimentos sociais, mesmo quando transformados em políticas públicas, nunca estão totalmente seguros contra as mudanças colocadas pelo jogo eleitoral democrático, isto é, pela alternância no poder. A pergunta a ser respondida é, então, como os movimentos sociais se protegem contra as incertezas dos resultados eleitorais? O caso analisado é o Movimento Municipalista de Saúde (1975-2010) e a hipótese oferecida como resposta é: para fugir dessas incertezas (normais em cenários de revezamento poliárquico) os movimentos sociais bus- 
cam acessos institucionalizados ao Estado e constroem novas instituições de modo a garantir maior permanência e estabilidade nos processos decisórios. $\mathrm{Ou}$, em nossos termos, buscam criar os encaixes e configuração de encaixes. Durante a transição democrática, o movimento municipalista constituiu uma associação de representação em nível federativo para poder reivindicar acesso à instância de planejamento no nível nacional. Após a promulgação da Constituição garantiu sua presença no novo Conselho Nacional da Saúde e, em seguida, propôs a criação de novas instituições, a saber, as Comissões Bipartite e Tripartite voltadas exclusivamente para a implementação da municipalização de serviços de saúde, a principal pauta do movimento. Em 2011, os atores do movimento elevaram o grau de sua influência ao inscrever sua institucionalização na Lei Orgânica de Saúde: garantiram à sua organização o estatuto de utilidade pública e de entidade representativa dos entes municipais e tornaram as Comissões Bipartite e Tripartite foros de negociação e pactuação entre gestores quanto aos aspectos operacionais do Sistema Único de Saúde. Os efeitos dessa institucionalização para o movimento social apontam para a transformação desse tipo de ação coletiva em outro tipo de ação, mas não para a desmobilização tout court.

O capítulo de Patrícia Tavares de Freitas foca a imigração boliviana e oferece diagnóstico instigante das transformações ocorridas na governança da política migratória no estado e cidade de São Paulo à luz da recomposição da imigração, da emergência de novos atores coletivos e da disputa partidária entre os principais contendentes da pós-transição em São Paulo, a saber, o Partido da Social Democracia Brasileira (PSDB) e o Partido dos Trabalhadores (PT). O campo da política migratória herdado da ditadura obedecia à lógica da segurança nacional e não dizia respeito ao principal contingente da imigração, oriundo do Nordeste. A nova imigração internacional, no caso, a imigração boliviana, acabou por reconfigurar um campo em que autoridades migratórias 
e de políticas sociais, bem como atores sociais das esferas civil e religiosa, tradicionalmente vinculados à assistência da população nordestina, foram interpelados pelas demandas desse novo ator urbano: o novo imigrante. A contribuição do capítulo ao livro é reconstruir de modo pioneiro, mediante a análise de três ciclos de interações socioestatais, a emergência de um domínio de agência de configuração dual de caráter societal-partidário, em que a institucionalização das demandas e os encaixes produzidos orbitam em torno de dois polos que ordenam, diferenciam e alinham ao PSDB e ao PT concepções diferentes das políticas, distintos órgãos da administração pública estadual e municipal, OSCs e entidades religiosas, associações de imigrantes e diversos lugares de circulação dos imigrantes na cidade.

Euzeneia Carlos, em seu capítulo, analisa o processo histórico de construção de encaixes institucionais e domínio de agência pelo movimento popular urbano, no Espírito Santo, um caso emblemático do processo de institucionalização de demandas e ações no Brasil pós-transição. Por meio de análise histórica longitudinal do movimento social, ao longo de três décadas (1980-2010), a autora reconstrói os processos de interação socioestatal a partir de fatores endógenos, donde derivam os encaixes com vistas a influenciar a agenda pública. $\mathrm{O}$ capítulo contribui duplamente com a proposta analítica do livro. Primeiro, ao identificar dois mecanismos na formação de encaixes e domínio de agência que tensionam a ideia de autonomia dos movimentos como ausência de relação com as instituições, quais sejam: (a) a relação com "incubadoras institucionais" na fundação do movimento e sua função no aprendizado e capacidades do ator, e (b) as alianças do movimento com coalizões partidárias nas eleições municipais e o papel dessas na permeabilidade do Estado. Segundo, ao analisar o perfil configuracional do domínio de agência forjado pelo movimento popular, composto além dos encaixes por capacidades organizacionais e interações socioestatais. O capítulo demonstra que organizações reli- 
giosas e partidos políticos de esquerda atuaram como incubadoras para o movimento contencioso, cujas relações pregressas geraram aprendizados e habilidades no ator para criar encaixes no Estado. Argumenta que um conjunto de encaixes, capacidades organizacionais e interações cooperativas configuram o domínio de agência do movimento popular, que prolonga no tempo sua influência política dada a exclusividade de acesso ao Estado e a legitimidade de agir em políticas específicas.

Enfatizando o processo de constituição mútua entre sociedade civil e Estado, o capítulo de Maria do Carmo Albuquerque analisa os resultados do movimento da criança e do adolescente na política socioeducativa. Por meio do exame de ciclos de mobilização do movimento, a autora inquire sobre sua incidência nas mudanças institucionais voltadas ao "paradigma garantista" na elaboração e implementação da política socioeducativa, no município de São Paulo. O capítulo oferece importante contribuição ao livro ao analisar as "coalizões de defesa" do paradigma garantista e seu sistema de crenças compartilhadas entre atores da sociedade civil e da sociedade política, especialmente seu papel na formação de encaixes institucionais com capacidade de incidência na política socioeducativa

$\mathrm{Na}$ segunda parte do livro, Flavia Rios analisa o processo de institucionalização do movimento negro brasileiro que, nas quatro últimas décadas, assume um duplo sentido: seja a institucionalização no movimento social mediante transformações em sua estrutura organizacional, seja a institucionalização na esfera do Estado por meio da construção de encaixes institucionais e de seus resultados em termos de incorporação da agenda societal. Seu capítulo oferece contribuição singular ao livro ao identificar nesse processo de institucionalização os encaixes institucionais que lograram resultados à inclusão da igualdade racial na agenda política. A autora sustenta que a dinâmica de interação do ativismo negro com as esferas executiva e burocrática do Estado, mediada 
por encaixes institucionais, assume relevo na explicação da institucionalização da agenda da igualdade racial no Brasil. Concernente à abordagem do livro, o capítulo aponta os encaixes enquanto um tipo de solidificação institucional que amplia a capacidade de influência dos atores, o qual requer certo padrão de complexificação organizacional do ator e de permeabilidade do Estado.

Em "Feminismos, movimentos de mulheres e as políticas de saúde para as mulheres", Layla Carvalho oferece uma rica análise de três articuladores civis em suas relações com a Política Nacional de Atenção Integral à Saúde da Mulher e o Programa Rede Cegonha. No caso específico, são analisadas as interações da Rede Feminista de Saúde, da Articulação de Mulheres Negras Brasileiras e da Rede pela Humanização do Parto e Nascimento com aquelas duas políticas do Ministério da Saúde. Vistos por lentes relacionais, os padrões de interação, mais ou menos próximos, mais ou menos cooperativos, de cada uma dessas redes vis-á-vis as políticas de saúde tendem a variar conforme os encaixes institucionais forjados com base na capacidade de ação e interpelação daquelas redes. Mais ainda: a variabilidade aí observada por Carvalho, especialmente no jogo de aproximações e distanciamentos entre atrizes civis e estatais, lança luz clarividente sobre a complexidade das dinâmicas e lógicas socioestatais. $\mathrm{O}$ leque de disputas e alianças arquitetadas ao redor de encaixes nas políticas públicas e seus instrumentos desautoriza qualquer simplificação teórica, demandando plasticidade e alcance analíticos adequados aos limites institucionais e aos liames sociopolíticos nos quais são forjadas percepções nativas (civis e estatais) tanto do que determinada política pública é, como daquilo que ela pode ou deveria ser.

Amiúde, a institucionalização de demandas de OSCs e MSs em uma determinada área de políticas é descrita em registro positivo pela literatura devido a seus efeitos de inclusão. Padrões de inclusão universalistas, como aqueles construídos no setor saúde pelo movimento pela reforma sanitária, todavia, podem obs- 
tar demandas de inclusão formuladas por grupos historicamente marginalizados. O capítulo de Vera Schattan Coelho e Adrian Gurza Lavalle se debruça sobre o movimento negro, com especial atenção para o movimento feminista negro, e sobre o trabalho de OSCs vinculadas aos Wajãpi, examinando, precisamente, a vocalização de suas demandas em relação ao sistema de saúde e à difícil recepção e absorção das mesmas por autoridades e profissionais de saúde habituados à linguagem técnica, a evidências estatísticas e princípios de atenção de índole universalista. Tais dificuldades acentuaram-se quando as demandas dos movimentos negro e indígena reivindicaram políticas específicas para a epidemia de HIV/ Aids. Mais: os próprios atores sociais tiveram que desenvolver repertórios discursivos para exigir políticas específicas em termos assimiláveis para os gestores da política setorial. A contribuição do capítulo ao livro é mostrar que tanto a formulação como a recepção de demandas são capacidades e, enquanto tais, não surgem espontaneamente, nem emergem de modo imediato da vontade dos atores, mas são produzidas ou, melhor, politicamente construídas ao longo do tempo por processos de interação socioestatal de resultados variáveis quanto aos níveis de institucionalização. No caso do movimento negro, esses processos levaram à edificação de um domínio de agência chamado de campo da saúde da população negra e à definição de políticas específicas para lidar com o HIV/Aids; já no caso do movimento indígena, sedimentara-se um subsistema de saúde de alcance mais modesto e pouco progresso houve no desenvolvimento de políticas de HIV/Aids capazes de funcionar porque consoantes à visão de mundo indígena.

Fechando o volume, José Szwako e Renato Perissinotto propõem um diálogo com a chamada "virada ideacional" ocorrida na literatura sobre políticas públicas como uma alternativa teórico-analítica adequada para aqueles que, como nós, querem deslindar variáveis e dimensões implicadas nas dinâmicas de institucionalização de demandas de movimentos sociais. 
Este capítulo reconstrói, primeiramente, a trajetória intelectual da ideia de 'gênero' forjada por redes, organizações e militantes do feminismo paraguaio, para em seguida observar como essa ideia foi incorporada e institucionalizada em duas políticas, quais sejam, a política de saúde sexual e reprodutiva, bem como a política de combate à violência contra a mulher. De olho nas interações socioestatais implicadas nos casos de institucionalização do componente de 'gênero', os autores sugerem a noção de capacidade cognitiva como uma dimensão interna às capacidades estatais heuristicamente fértil para a compreensão das formas pelas quais os movimentos sociais podem ter seus projetos e ideais transformados em instituições.

\section{REFERÊNCIAS}

ABERS, Rebecca; KECK, Margaret. Practical Authority: Agency and Institutional Change in Brazilian Water Politics. Oxford: Oxford University Press, 2013.

ABERS, Rebecca; OLIVEIRA, Marilia S.; PEREIRA, Ana. K. Inclusive Development and the Asymmetric State: Big Projects and Local Communities in the Brazilian Amazon. The Journal of Development Studies, 2017, v. 53, n. 6, pp. 857-872.

ABERS, Rebecca; SERAFIM, Liza; TATAGIBA, Luciana. Repertórios de interação Estado-sociedade em um Estado heterogêneo: a experiência na era Lula. Dados, 2014, v. 57, n. 2, pp. 325-357. Disponível em: <http://dx.doi. org/10.1590/0011-5258201411>.

ABERS, Rebecca; VON BÜLOW, Marisa. Movimentos sociais na teoria e na prática: como estudar o ativismo através da fronteira entre Estado e sociedade? Sociologias, 2011, n. 28, pp. 52-84. Disponível em: <http://dx.doi.org/10.1590/ S1517-45222011000300004>.

ALMEIDA, Débora R. Representação além das eleições: repensando as fronteiras entre Estado e sociedade. Jundiaí: Paco Editorial, 2015. 
ALONSO, Angela; COSTA, Valeriano; MACIEL, Débora. Identidade e estratégia na formação do movimento ambientalista brasileiro. Novos Estudos Cebrap, 2007, v. 79, pp. 151-167.

AMENTA, Edwin et al. Challengers and States: Toward a Political Sociology of Social Movements. Sociological Views on Political Participation, 2002, v. 10, pp.47-83.

AMENTA, Edwin et al. Age for Leisure? Political Mediation and the Impact of the Pension Movement on US Old Age Policy. American Sociological Review, 2005, v. 70, pp.516-538.

AMENTA, Edwin et al. The Political Consequences of Social Movements. Annual Review of Sociology, 2010, v. 36, pp. 287-307.

ARDITI, Benjamin. El devenir-otro de la política: un archipiélago post-liberal. In: Arditi, Benjamin (Ed.) ¿Democracia post-liberal? El espacio político de las asociaciones. México: Anthropos/UNAM, 2005, pp. 219-248.

BANASZAK, Lee A. Inside and Outside the State: Movement Insider Status, Tactics, and Public Policy Achievements. In: Meyer, David et al. (Ed.) Routing the Opposition: Social Movements, Public Policy, and Democracy. Minneapolis: University of Minnesota Press, 2005, pp. 149-176.

BICHIR, Renata; BRETTAS, Gabriela; CANATO, Pamela. Multi-level Governance in Federal Contexts: the Social Assistance Policy in the City of São Paulo. Brazilian Political Science Review, 2017, v. 11, n. 2, e0003. Epub July 27.

BOSCHI, Renato. Corporativismo societal, a democratização do Estado e as bases social-democratas do capitalismo brasileiro. Insight Inteligência, 2010, v. 48, pp. 1-20.

BROWNE, William P. Organized Interests and their Issue Niches: A Search for Pluralism in a Policy Domain. The Journal of Politics, 1990, v. 52, n. 2.

CARLOS, Euzeneia. Movimentos sociais e instituições participativas: efeitos organizacionais, relacionais e discursivos. Tese (Doutorado em Ciência Política) - Universidade de São Paulo, São Paulo, 2012.

CARLOS, Euzeneia. Movimentos sociais e instituições participativas: efeitos do engajamento institucional no contexto pós-transição. Belo Horizonte: Fino Traço, 2015. 
CARLOS, Euzeneia; DOWBOR, Monika; ALBUQUERQUE, Maria do C. Movimentos sociais e seus efeitos nas políticas públicas: balanço do debate e proposições analíticas. Civitas, 2017, v. 17, n. 2, pp. 360-378.

CHAMBRÉ, Susan; FATT, Naomi. Beyond the Liability of Newness: Nonprofit Organizations in an Emerging Policy Domain. Nonprofit and Voluntary Sector Quarterly, 2002, v. 31.

CHARTOCK, Sarah. Corporatism with Adjectives? Conceptualizing Civil Society Incorporation and Indigenous Participation in Latin America, Latin American Politics and Society, 2013, v. 55, n. 2, pp. 52-76.

CINGOLANI, Luciana. The State of State Capacity: A review of Concepts, Evidence and Measures. UNU-Merit Working Paper Series on Institutions and Economic Growth, 2013. IPD WP13.

CLEMENS, Elizabeth. Organizational Repertoires and Institutional Change: Women's Groups and the Transformation of US Politics, 1890-1920. American Journal of Sociology, 1993, v. 98, n. 4.

CLEMENS, Elizabeth. The People's Lobby. Organizational Innovation and the Rise of Interest Group Politics in the United States, 1890-1925. Chicago: Chicago University Press, 1997.

CLEMENS, Elizabeth. Two Kinds of Stuff: The Current Encounter of Social Movements and Organizations. In: Davis, Gerald et al. (Ed.) Social Movements and Organization Theory. Cambridge: Cambridge University Press, 2005, pp.351-365.

COLlIER, Ruth; HANDLIN, Samuel (Ed.) Reorganizing Popular Politics: Participation and the New Interest Regime in Latin America. University Park, PA: Pennsylvania State University Press, 2009.

DAGNINO, Evelina. Civil Society in Latin America. In: Edwards, Michael (Ed.) The Oxford Handbook of Civil Society. Oxford: Oxford University Press, 2011.

DAHL, Robert. Who Governs?: Democracy and Power in an American City. New Haven: Yale University Press, 1961.

DAHL, Robert. Um prefácio à teoria democrática. Rio de Janeiro: Jorge Zahar, 1989. 
DAHL, Robert. Los dilemas del pluralismo democrático. Autonomía versus control. México: Alianza Editorial/Conaculta, 1991.

DAHL, Robert. Poliarquia: participação e oposição. São Paulo: EdUSP, 1997.

DIANI, Mario. Networks and social movements: a research programme. In: Diani, Mario; McAdam, Doug (Eds) Social Movements and networks. Relational approaches to collective action. Oxford University Press, 2003, pp. 298-319.

DOWBOR, Monika. A arte da institucionalização: estratégias de mobilização dos sanitaristas (1974-2006). Tese (Doutorado em Ciência Política) Universidade de São Paulo, São Paulo, 2012. Disponível em: <http://dx.doi. org/10.11606/T.8.2012.tde-06032013-111003>.

EVANS, Peter. Embedded Autonomy: States and Industrial Transformation. Princeton, NJ: Princeton University Press, 1995.

GEDDES, Barbara. Politician's Dilemma: Building State Capacity in Latin America. Berkeley: University of California Press, 1994.

GOLDSTONE, Jack. Bridging Institucionalized and Noninstitucionalized Politics. In: States, Parties, and Social Movements. Cambridge: Cambridge University Press, 2003.

GOODWIN, Jeff. Revolutions and Revolutionary Movements. In: Janoski, Thomas et al. (Ed.). The Handbook of Political Sociology: States, Civil Societies, and Globalization. Cambridge: Cambridge University Press, 2003.

GURZA LAVALLE, Adrian. Crítica ao modelo da nova sociedade civil. Lua Nova, 1999, v. 47, pp.121-135.

GURZA LAVAlle, Adrian; ACHARYA, Arnab; HOUTZAGER, Peter. Beyond comparative anecdotalism: lessons on civil society and participation from São Paulo, Brazil. World Development, 2005, v. 33, n. 6, pp. 951-964.

GURZA LAVALLE, Adrian; HOUTZAGER, Peter; CASTELLO, Graziela. Representação política e organizações civis: novas instâncias de mediação e os desafios da legitimidade. Revista Brasileira de Ciências Sociais, 2006a, v. 21, n. 60, pp.43-66.

GURZA LAVALLE, Adrian; HOUTZAGER, Peter; CASTELLO, Graziela. Democracia, pluralização da representação e sociedade civil. Lua Nova, 2006b, v. 67, pp. $49-103$. 
GURZA LAVALLE, Adrian; HOUTZAGER, Peter; CASTELLO, Graziela. A construção política das sociedades civis. In: Gurza Lavalle, Adrian (Ed.). $O$ horizonte da politica: questões emergentes e agendas de pesquisa. São Paulo: EdUnesp/Cebrap/CEM, 2012, pp. 185-259.

GURZA LAVALLE, Adrian; ISUNZA, Ernesto. A trama da crítica democrática: da participação à representação e à accountability. Lua Nova, 2011, v. 84, pp. 95-140.

GURZA LAVALLE, Adrian; SZWAKO, José. Sociedade civil, Estado e autonomia: argumentos, contra-argumentos e avanços no debate. Opinião Pública, 2015, v. 21, n. 1, pp. 157-187.

GUTIERRES, Kellen A. Projetos politicos, trajetórias e estratégias: a politica de assistência social entre o partido e o Estado. Tese (Doutorado em Ciências Sociais) - Universidade Estadual de Campinas, Campinas, 2015.

HANAGAN, Michael. Social Movements, Incorporation, Disengagement, and Opportunities - a Long View. In: Giugni, Marco; McAdam, Doug; Tilly, Charles (Ed.) From Contention to Democracy. Lanham, MA: Rowman and Littlefield, 1998.

HOUTZAGER, Peter. Os últimos cidadãos: conflito e modernização no Brasil rural (1964-1995). São Paulo: Globo, 2004.

HOUTZAGER, Peter; GURZA LAVALlE, Adrian; ACHARYA, Arnab. Atores da sociedade civil e atores políticos: participação nas novas políticas democráticas em São Paulo. In: Avritzer, Leonardo (Org.). A participação em São Paulo. São Paulo: EdUnesp, 2004.

HOUTZAGER, Peter; KURTZ, Marcus. The Institutional Roots of Popular Mobilization: Transformation and Rural Politics in Brazil and Chile, 1960-95. Comparative Studies in Society and History, 2000, v. 42, n. 2, pp. 394-424.

KINGDON, John. Agendas, Alternatives, and Public Policies. New York: Harper Collins, 1995.

KJAER, Anne Mette et al. Conceptualizing State Capacity. Democracy, the State, and Administrative Reforms. Demstar Research Report, n. 6, University of Aarhus, 2002.

KNOKE, David. Networks of Elite Structure and Decision Making. Sociological Methods and Research, 1993, v. 22, n. 1. 
KNOKE, David. Comparing Policy Networks: Labor Politics in the US, Germany, and Japan. Cambridge: Cambridge University Press, 1996.

KRIESI, Hans P. La estructura organizacional de los nuevos movimientos sociales en su contexto político. In: McAdam, Doug; McCarthy, John; Zald, Mayer (Ed.). Movimientos sociales: perspectivas comparadas. Madrid: Istmo, 1999, pp. 221-261.

LASCOUMES, Pierre; LE GALÈS, Patrick. Introduction: Understanding Public Policy through its Instruments. Governance: An International Journal of Policy, Administration, and Institutions, 2007, v. 20, n. 1, pp. 1-21.

LINDVALL, Johannes; TEORELL, Jan. State Capacity as Power: A Conceptual Framework. 2017. Disponível em: <https://projects.iq.harvard.edu/files/ pegroup/files/lindvallteorell2017_updated.pdf $>$.

LOWI, Theodore. Four Systems of Policy, Politics, and Choice. Public Administration Review, 1972, v. 32, n. 4, pp. 298-310.

MAHONEY, James. Nominal, Ordinal, and Narrative Appraisal in Macrocausal Analysis. The American Journal of Sociology, 1999, v. 104, n. 4, pp. 1154-1196.

MAHONEY, James. Path Dependence in Historical Sociology. Theory and Society, 2000, v. 29, n. 4, pp. 507-548.

MANLEY, John. Neo-pluralism: A class analysis of pluralism I and pluralism II. American Political Science Review, 1983, v. 77, n. 2.

MANN, Michael. The Autonomous Power of the State: Its Origins, Mechanisms and Results. Archives Européenne de Sociologie, 1984, v. 25, pp. 185-213.

MANN, Michael. The Sources of Social Power: The Rise of Classes and NationStates, 1760-1914. v. 2. New York: Cambridge University Press, 1993.

MANN, Michael. Infrastructural Power Revisited. Studies in Comparative International Development, 2008, v. 43, pp. 355-365, Doi:10.1007/s12116008-9027-7.

MARCH, James; OLSEN, Johan. The New Institutionalism: Organizational Factors in Political Life. American Political Science Review, 1984, v. 78, pp. 734-759. 
MARQUES, Eduardo C. Notas críticas a literatura sobre Estado, políticas estatais e atores políticos. BIB: Revista Brasileira de Informação Bibliográfica em Ciências Sociais, 1997, v. 43.

MARQUES, Eduardo C. Redes sociais e poder no Estado brasileiro: aprendizados a partir de políticas urbanas. Revista Brasileira de Ciências Sociais, 2006, v. 21, n. 60, pp. 15-41.

MCADAM, Doug; SCOTT, R. Organizations and Movements. In: Davis, Gerald F. et al. (Ed.). Social Movements and Organization Theory. Cambridge: Cambridge University Press, 2005.

MCADAM, Doug; TARROW, Sidney; TILLY, Charles. Dynamics of Contention. Cambridge: Cambridge University Press, 2001.

MCCARTHY, John; ZALD, Mayer. The Trends of Social Movements in America: Professionalization and Resource Mobilization. Morristown, NJ: General Learning Press, 1973.

MCNULTY, Stephanie. Participatory Democracy? Exploring Peru's Effort to Engage Civil Society in Local Governance. Latin America Politics and Society, 2013, v. 55, n. 3, pp. 69-92.

MEYER, David S.; TARROW, Sidney (Ed.). The Social Movement Society: Contentions Politics for a New Century. Lanham, MA: Rowman and Littlefield, 1998.

NETTL, J. P. The State as a Conceptual Variable. World Politics, 1968, v. 20 , n. 4, pp. 559-592.

OFFE, Claus. Capitalismo desorganizado. São Paulo: Brasiliense, 1998.

PEREIRA, Ana K. A construção de capacidade estatal por redes transversais: $o$ caso de Belo Monte. Tese (Doutorado em Ciência Política) - Universidade de Brasília, Brasília, 2014.

PIRES, Roberto; GOMIDE, Alexandre. Governança e capacidades estatais: uma análise comparativa de programas federais. Revista Sociologia e Politica, 2016, v. 24, n. 58, pp. 121-143.

PIVEN, Frances F.; CLOWARD, Richard. Poor People's Movements: Why They Succeed, How They Fail. New York: Vintage Books, 1979. 
SABATIER, Paul. The Need for Better Theories. In: Sabatier, Paul (Ed.). Theories of Policies Process. Boulder, CO: Westview Press, 2007, pp. 3-20.

SABATIER, Paul; WEIBLE, Christopher. The Advocacy Coalition Framework: Innovations and Clarifications. In: Sabatier, Paul (Ed.). Theories of Policies Process. Boulder, CO: Westview Press, 2007, pp. 189-222.

SALISBURY, Robert; HEINZ, John; LAUMANN, Edward; NELSON, Robert. Who Works with Whom? Interest Group Alliances and Opposition. The American Political Science Review, 1987, v. 81, n. 4.

SCHLOSBERG, David Resurrecting the Pluralist Universe. Research Quarterly, 1998, v. 51, n. 3, pp. 583-561.

SCHMITTER, Philipe. Still the Century of Corporatism? Review of Politics, 1974, n. 36, pp. 85-131.

SCHMITTER, Philipe. The Consolidation of Democracy and Representation of Social Groups, American Behavioral Scientist, 1992, v. 35, n. 4-5, pp. $422-449$.

SCHMITTER, Philipe. Some Propositions about Civil Society and the Consolidation of Democracy. Wien: Institut für Höhere Studien, 1993.

SCHMITTER, Philipe. Un posible esbozo de una democracia 'post-liberal'. In: Arditi, Benjamin (Ed.). ¿Democracia post-liberal? El espacio politico de las asociaciones. México: Anthropos/UNAM, 2005, pp. 249-263.

SILVA, Marcelo K.; OLIVEIRA, Gerson. A face oculta(da) dos movimentos sociais: trânsito institucional e intersecção Estado-Movimento: uma análise do Movimento de Economia Solidária no Rio Grande do Sul. Sociologias, 2011, ano 13, n. 28, pp. 86-124.

SKOCPOL, Theda. States and Social Revolutions: A Comparative Analysis of France, Russia, and China. Cambridge, UK: Cambridge University Press, 1979.

SKOCPOL, Theda. Bringing the State Back In: Strategies of Analysis in Current Research. In: Evans, Peter; Rueschemeyer, Dietrich; Skocpol, Theda (Ed.). Bringing the State Back In. Cambridge, UK: Cambridge University Press, 1985.

SKOCPOL, Theda. Protecting Soldiers and Mothers: The Political Origins of Social Policy in the United States. Cambridge, MA: Harvard University Press, 1992. 
SKOCPOL, Theda. Why I Am an Historical Institutionalist. Polity, 1995, v. 28, n. 1, pp. 103-106.

SKOCPOL, Theda. Diminished Democracy. From Membership to Management in American Civic Life. Norman, OK: University of Oklahoma Press, 2003.

SKOCPOL, Theda. Bringing the State Back In: Retrospect and Prospect. The 2007 Johan Skytte Prize Lecture. Scandinavian Political Studies, 2008, v. 31, n. 2, pp. 109-124.

SKOCPOL, Theda; CROWLEY, J. E. The Rush to Organize: Explaining Associational Formation in the United States, 1860s-1920s. American Journal of Political Science, 2001, v. 45, n. 4, pp. 813-829.

SKOWRONEK, Stephen. Building a New American State: The Expansion of National Administrative Capacities, 1877-1920. Cambridge, UK: Cambridge University Press, 1982.

SZWAKO, José. 'Del otro lado de la vereda': luta feminista e construção democrática no Paraguai pós-ditatorial. Tese (Doutorado em Ciências Sociais) - Universidade Estadual de Campinas, Campinas, 2012.

SZWAKO, José. Incorporação estatal e reprodução institucional: ou como observar os efeitos institucionais da ação coletiva. In: Congresso Internacional da Latin American Studies Association (LASA), 31., 2013, Washington, DC. 2013.

TARROW, Sidney. El poder en movimiento: los movimientos sociales, la acción colectiva y la politica. Madri: Alianza, 1997.

TATAGIBA, Luciana; BLIKSTAD, Karin. Como se fosse uma eleição para vereador: dinâmicas participativas e disputas partidárias na cidade de São Paulo. Lua Nova, 2011, n. 84, pp. 175-217.

TILLY, Charles. Reflections on the History of European State-Making. In: Tilly, Charles (Ed.). The Formation of National States in Western Europe. Cambridge, MA: Harvard University Press, 1975, pp. 3-83.

TILLY, Charles. Coerção, capital e estados europeus. São Paulo: EdUSP, 1996.

TILLY, Charles. Mechanisms in Political Processes. Annual Review of Political Science, 2001, v. 4, pp. 21-41. 
TILLY, Charles. The Politics of Collective Violence. Cambridge, UK: Cambridge University Press, 2003.

TILLY, Charles; TARROW, Sidney (2007), Contentious Politics. Boulder, CO: Paradigm Publishers, 2007.

TRUMAN, David. The Governamental Process: Political Interest and Public Opinion. Westport, CT: Greenwood Press, 1951.

VITE, Francisco. Offe, Schmitter y la institucionalización de un segundo circuito de la política. In: Arditi, Benjamín (Ed.). ¿Democracia post-liberal? El espacio político de las asociaciones. México: Anthropos/UNAM, 2005, pp. 145-172.

ZAREMBERG, Gisela; GURZA LAVALLE, Adrian; GUARNEROS-MESA, Valeria. Beyond Elections: Representation Circuits and Political Intermediation. In: Zaremberg, Gisela et al. (Ed.). Intermediation and Representation in Latin America: Actors and Roles Beyond Elections. London: Palgrave Macmillan, 2017, pp. 1-30. 
PRIMEIRA PARTE

Movimentos e políticas sociais

no Brasil pós-transição 



\author{
Capítulo 1 \\ ESCAPANDO DAS INCERTEZAS DO JOGO \\ ELEITORAL: A CONSTRUÇÃO DE ENCAIXES \\ E DOMínIO DE AGÊNCIA DO MOVIMENTO \\ Municipalista de Saúde ${ }^{1}$
}

Monika Dowbor

\title{
1. Introdução
}

Embora, enquanto pesquisadores, procuremos analisar os movimentos sociais em suas relações com o Estado entendido como um conjunto de instituições e burocracias (Tatagiba, 2010; Silva e Oliveira, 2011; Abers e von Bulow, 2011; Carlos, 2015), os atores coletivos interagem muito frequentemente, conflituando ou cooperando, com os governos que resultam das eleições e têm validade marcada por um mandato. Nesse lapso de tempo eleitoral democrático, ainda que herdem as instituições dos seus antecessores, os novos detentores de poder e seus executores podem introduzir mudanças nas políticas públicas (Mahoney e Thelen, 2010). Podem descontinuá-las, podem imprimir outro estilo na implementação ou promover novos programas. Essa impermanência do poder não é desconhecida pelos movimentos. ${ }^{2}$ Ainda que constrangido pelo legado institucional, um partido no exercício de

1 Este texto aproveita trechos da minha tese de doutorado (Dowbor, 2012), ainda que sob outro foco analítico.

2 Sigo neste texto a seguinte definição de movimentos sociais "uma rede de interações informais entre uma pluralidade de indivíduos, grupos e/ou organizações, engajados em um conflito político ou cultural, com base em identidades compartilhadas" (Diani, 1992, p. 1). 
mandato pode levar as reivindicações de movimentos adiante ou, bem ao contrário, fazê-las regredir ou negá-las. Essas oportunidades e ameaças políticas são produzidas independentemente de ação do movimento (McAdam, 2006) e, nesse sentido, a atuação do movimento seria resposta às disputas e aos resultados do sistema político-eleitoral que estão além da capacidade de interferência direta do movimento (McAdam e Tarrow, 2011). Certos graus de incerteza - as tais contingências - fazem parte dos horizontes da ação de movimentos sociais.

Esse não é o infortúnio desse tipo de ação coletiva. Muitos movimentos não querem estar nas instituições e preferem sua posição de outsiders por uma série de razões. Porém há outros que podem querer se precaver contra as contingências do jogo eleitoral e o fazem, atuando, sobretudo, por meio das instituições. Essas táticas foram identificadas em diversas pesquisas nas duas últimas décadas e incorporadas ao repertório de ação de movimentos sociais, até então predominantemente focado em confronto extrainstitucional (McAdam e Tarrow, 2011; Dowbor, 2012; Carlos, 2012; Abers, Serafim e Tatagiba, 2014). Mostrou-se que os atores de movimentos não se restringem às ruas, interpretam as regras, conhecem o funcionamento das instituições do Estado e utilizam-nas a seu favor, prorrogando sua interferência nos processos decisórios por meio da participação em instituições participativas, da ocupação de cargos em governos etc. E que com toda essa atuação via instituições não deixam de ser movimentos. Se a proposta analítica deste livro permite avançar na compreensão desses processos de institucionalização, o presente capítulo visa capturar analiticamente os momentos nos quais os movimentos buscam escapar às contingências do jogo eleitoral, tornando seu acesso aos processos decisórios no Estado mais permanente.

Isto é, procuram se encaixar nos pontos de acesso abertos pelo Estado ou construir novos pontos de influência. Para poder observar analiticamente esses processos, as categorias de encaixe e de configurações de encaixes, enquanto domínio de agência, 
oferecem a lente necessária (Skocpol 1992). Permitem enxergar analiticamente esses acessos, seu grau de influência nos processos decisórios (menor no caso de encaixes, maior no caso de domínio de agência) e sua duração no tempo.

O encaixe implica certa permeabilidade do Estado a interesses societais na medida em que pressupõe a existência de pontos de acesso e de influência, historicamente mutáveis, permitidos pelas instituições políticas de uma nação, abertos a alguns atores e negados a outros (Skocpol, 1992). O encaixe ocorre quando um grupo politicamente ativo, orientado por objetivos e dotado de capacidades consegue acessar um desses pontos de influência. Um cargo comissionado, por exemplo, pode ser considerado um ponto de acesso, aberto temporariamente, isto é, enquanto dura a coalizão formulada a partir do resultado das eleições. Ao ocupar esse cargo, ou, na nossa nomenclatura, ao construir um encaixe entre o movimento e o Estado, aquele passa a ter certa influência em algum processo decisório.

Obviamente, os pontos de acesso e, por conseguinte, os encaixes, se diferenciam entre si em termos de poder de influência que oferecem e de tempo de sua abertura a um dado ator. Pode se pressupor que os movimentos procurarão os pontos de maior influência, mas como esses são os mais disputados, a estratégia pode passar por arquitetar encaixes em diferentes pontos de acesso às instituições. A essas configurações de encaixes aos quais chegam os movimentos nas suas interações com o Estado denominamos, neste livro, de domínios de agência. Estes ocorrem quando o movimento alcança, conquista ou constrói a capacidade de agir em determinado âmbito de políticas públicas sob responsabilidade direta ou indireta do Estado (Gurza Lavalle, Houtzager e Castello, 2012). Ter o domínio de agência significa que a ação do ator que o possui é favorecida em relação à de outros atores. Isto é, que ele é reconhecido como ator legítimo em uma dada política pública; que seus problemas e pautas constituem a matéria de relevância; 
que existe suporte organizacional e financeiro para sua atuação e que seu acesso ao Estado é privilegiado em comparação com outros atores que disputam um dado campo.

Do ponto de vista analítico, os conceitos de encaixe e de domínio de agência prolongam nossa capacidade de observar a atuação de movimentos sociais em interação com o Estado. De um lado, permitem resistir à aplicação precipitada das sequências analíticas de mobilização - institucionalização - desmobilização ou de autonomia - institucionalização - cooptação, ao inserir um instrumental analítico capaz de perceber as engrenagens dessa institucionalização e as lentas transformações do e no movimento. A desmobilização continua sendo uma possibilidade analítica acrescida pela capacidade de observar a geração de outras formas de ação coletiva para além de movimento social. Compreender a continuidade da ação coletiva apesar das diferenças nos seus tipos é uma vantagem que se abre com o uso desses conceitos. Do outro lado, permitem compreender melhor graus de (im)permeabilidade do Estado (Marques, 2006) e distinguir as mudanças no próprio Estado na medida em que os movimentos sociais podem construir novas instituições (novos pontos de acesso, portanto) ou introduzem mudanças incrementais nas já existentes.

Como distinguir encaixe de repertório de ação de movimentos sociais? A pergunta se coloca na medida em que existe certa justaposição entre as instâncias empíricas do repertório de interação e as do encaixe. A ocupação de cargos em governos é um exemplo disso. A primeira distinção é que os encaixes implicam sempre o acesso às instituições, enquanto o repertório de interação inclui as formas extrainstitucionais como protestos. A segunda diferença então consistirá na forma de análise que cada conceito permite. O conceito de repertório é voltado para catalogar as formas de ação de movimentos sociais, dando ênfase ao seu caráter histórico e sem se preocupar com seu grau de influência nos processos decisórios, o que constitui o cerne da definição do encaixe. $\mathrm{O}$ repertório se 
volta para responder perguntas sobre a diversidade de ação de um movimento ou a comparação entre os movimentos, ou ainda sobre a legitimidade de certas performances em detrimento de outras. A principal pergunta que pode ser respondida por meio do conceito de encaixe, por sua vez, é quanta influência é alcançada à medida que ele ocorre.

O caso empírico aqui relatado à luz dessas categorias pertence à trajetória do Movimento Sanitário (chamado também de Movimento pela Reforma Sanitária) que começou suas primeiras mobilizações no final dos anos 1970 (Escorel, 1998) e está atuante até hoje engajado sempre na luta pelo sistema público, universal, gratuito e integral de saúde (Dowbor, 2012). É um movimento composto por profissionais de saúde, professores, estudantes, organizações diversas, entre as quais as mais longevas são o Centro Brasileiro de Estudos de Saúde (Cebes) e a Associação Brasileira de Pós-Graduação em Saúde Coletiva (Abrasco). Em suas diferentes vertentes e formatos organizacionais, o movimento esteve engajado em diversas companhas entre 1979 e 2012, entre as quais a mobilização na Constituinte (1986-1988) com a aprovação do Sistema Único de Saúde na Carta Magna, na defesa da Lei Orgânica de Saúde (1991-1992) e campanha pelo financiamento (2004-2012). O Movimento pela Reforma Sanitária lançou mão em suas mobilizações de um conjunto de ações via instituições para influenciar os processos decisórios na luta pelo sistema universal de saúde. A atenção deste capítulo vai recair sobre uma vertente do movimento que se autodenominou de municipalista e que na sua luta pela saúde pública focou a necessidade da municipalização dos serviços públicos de saúde, praticamente inexistentes nos anos 1970. A sua trajetória desde aquela década até os dias de hoje é marcada pelos sucessivos esforços em garantir a influência nos processes decisórios: encaixando-se nos pontos de acesso já existentes nas instituições; criando novos pontos de acesso ao Estado e, por fim, gerando uma configuração de encaixes que outorgou uma capacidade especial 
de influência na política pública de municipalização de saúde pública no Brasil.

O Movimento Municipalista será capturado em três quadros de modo a evidenciar esses processos de mobilização e institucionalização concomitantes. A seleção dos quadros foi analítica, o que já assinala ao leitor de que não encontrará nas linhas abaixo o retrato completo desse movimento, que pode ser lido alhures. ${ }^{3}$ No primeiro, serão reconstruídos os primórdios do movimento em suas primeiras mobilizações e formas organizacionais, chamando atenção para o primeiro tipo de encaixe arquitetado no Estado, quando ativistas ocuparam cargos no nível municipal. No segundo, vamos observar os esforços do movimento municipalista em criar encaixe no nível federal ao mesmo tempo em que continuam se mobilizando na luta pela constituição e implementação do Sistema Único de Saúde. No terceiro quadro veremos de que maneira esse ator busca escapar deliberadamente às contingências eleitorais ao construir novos pontos de acesso que tornariam não só mais forte a sua influência nos processos decisórios, mas também independente do resultado do jogo eleitoral.

A pesquisa de caráter qualitativo que embasou a seguinte descrição se apoiou em três fontes de evidências: jornais e publicações do Movimento editadas em momentos históricos do interesse analítico; nas entrevistas com os militantes, realizadas pela autora ou por terceiros bem como nos estudos já realizados que abundam na área de saúde pública no Brasil.

\section{A mútua constituição entre movimento social e Estado: primeiras mobilizações e primeiros encaixes do Movimento Municipalista}

O Movimento Municipalista de saúde começa a se organizar e mobilizar a partir de pontos de acesso ao Estado abertos nos

3 Cf. Conasems $(2003,2007)$. 
anos 1970 a atores societais: trata-se de cargos de nomeação nos governos municipais disponíveis após as eleições disputadas entre dois partidos permitidos pelo regime militar. Alguns ativistas ocupam esses postos relacionados com o setor de saúde e enquanto implementam, na contramão do sistema em vigência, os serviços públicos de saúde, organizam-se e mobilizam como atores coletivos em torno dessa causa.

Os cargos foram assumidos na vitória eleitoral do partido de oposição autorizado pelo regime militar, o Movimento Democrático Brasileiro (MDB), em 1976. Os três secretários identificados com o Movimento, nos municípios de Londrina, Niterói e Campinas (Conasems, 2007), tinham em comum a origem universitária em cursos voltados para a saúde pública (de medicina preventiva, cursos de saúde pública ou saúde comunitária) dos quais se originaram os quadros do Movimento, e a atuação nos trabalhos em comunidade. A ocupação de cargos constituía na época uma tática deliberada do Movimento, usada principalmente pelos ativistas ligados ao Partido Comunista Brasileiro, que optou pela via de reformas por dentro do Estado como forma de atuação.

Uma das expressões da mobilização do movimento foi a realização dos Encontros do Setor Municipal de Saúde, entre 1978 e 1980. A organização desses encontros sob a fachada burocrática em função da repressão do regime, bem como a paulatina montagem de organizações que agregavam ativistas engajados na municipalização da saúde caracterizam o nascedouro do movimento. A ideia da realização de tais eventos municipais teria nascido nas reuniões clandestinas (reuniões chamadas de Projeto Andrômeda) dos quais participavam os ativistas mais engajados (Almeida apud Goulart, 1996). O que revela o protagonismo do movimento era o fato de serem realizados justamente onde os militantes estavam ocupando cargos dirigentes do setor municipal de saúde. 
Com base no acerto entre os secretários, cada um dos municípios abrigaria, sucessivamente, os três primeiros encontros (Goulart, 1996, p. 38). O primeiro encontro foi realizado, pois, em Campinas, em 1978; o segundo, em 1979, em Niterói; e, em 1981, o encontro programado para ser realizado em Londrina foi transferido, porém, para Belo Horizonte, porque o sanitarista havia sido afastado do cargo. Esses encontros estavam "para além da gestão pública”, como disse um dos militantes (Santos, 20082009). A sua fachada burocrática e estatal escondia os eventos que mobilizavam e agregavam comunidades atendidas pelos novos serviços municipais, profissionais reformistas, grupos e ativistas de diferentes vertentes do Movimento. Eram politizados, pois neles se discutiam a democratização e o projeto do sistema público, universal, gratuito de saúde, descentralizado e controlado pela população (Carvalho, entrevista, 2012).

No período em foco, nos anos 1970, ainda tratava-se de um projeto, porque na época o tal sistema não existia. Os trabalhadores formais e, portanto, contribuintes do sistema previdenciário eram atendidos junto com seus dependentes por um sistema da assistência médica da previdência social, sob o comando do Instituto Nacional de Assistência Médica da Previdência Social (Inamps). Aos demais que correspondiam, em 1977, a um pouco mais da metade da população do país (Possas, 1980), restavam as organizações filantrópicas como as santas casas e os rarefeitos equipamentos públicos geridos principalmente pela secretarias estaduais. Os municípios, que não eram entes autônomos da Federação naquele tempo, na sua grande maioria não detinham instâncias responsáveis pela saúde.

Assim, em 1973, 73,4\% dos municípios não possuíam maternidades, $57 \%$ não tinham hospitais e $90 \%$ não dispunham de prontos-socorros (Carvalho, 2011, p. 62). Na maior parte dos municípios, sequer havia uma secretaria de saúde propriamente dita, 
e os poucos serviços eram geridos em outras secretarias ou em espaços que agregavam diversos serviços sociais (Conasems, 2007, p. 61). Em Londrina, quando o ativista Marcio de Almeida assumiu o cargo, a secretaria não dispunha de nenhum médico e nenhum posto de saúde funcionando regularmente:

A Secretaria funcionava na época para tomar conta de parques infantis, pois existiam consultórios médicos instalados só em uma das duas creches comunitárias para atender as crianças e o Pronto-Socorro Municipal era conveniado com o Hospital Universitário para o qual a Prefeitura repassava os recursos da saúde (Almeida, entrevista, apud Conasems, 2007, p. 75).

A Secretaria de Niterói, outra ocupada por um militante, era conhecida como "secretaria de morte", pois dispunha apenas de um serviço funerário e um posto de saúde, cedido, todavia, à Secretaria Estadual de Saúde em comodato. O que esses municípios tinham em comum, antes que os ativistas assumissem os cargos de comando setorial, era quase completa falta de serviços municipais de saúde.

A construção inicial das capacidades estatais de produção de serviços de saúde no nível municipal se deveu ao trabalho dos militantes do movimento. Nas eleições de 1982 - portanto, ainda sob o regime militar, mas no quadro do pluripartidarismo introduzido pelos militares com o objetivo de fragmentar a oposição até então reunida no $\mathrm{MDB}$-, os municipalistas assumiram cargos em mais algumas cidades como Piracicaba, Bauru, São José dos Campos, Santos, Diadema, Santo André, Campinas, Piracicaba, Itu, Uberlândia etc. E em todos esses municípios instalavam novos postos de atendimento, principalmente nas áreas mais pobres das cidades, expandiam especialidades médicas e implementavam novos programas (Capistrano Filho e Pimenta, 1988). 
O que era restrito à presença dos ativistas ganhou ampliação a partir de 1983, com a implementação do Programa das Ações Integradas (AIS), desenvolvido também pelos ativistas do Movimento infiltrados na agência federal responsável pelo sistema de saúde voltado aos trabalhadores formais, o Inamps, detentor da parte leonina de recursos setoriais e com forte infiltração dos interesses da medicina privada (Falleti, 2010). Por meio desse programa nacional, os recursos federais passavam a fluir aos municípios e estados para a implementação dos serviços públicos.

Assim, os municípios que não necessariamente contavam com a presença de ativistas passavam a implementar o serviços e nesse processo a enfrentar dificuldades para a implementação, tais como a elaboração de um Plano Diretor necessário para assinar o convênio das AIS e a própria implementação de serviços, que ainda precisava ser "inventada" (Cosem-SP, 2008, p. 11). Sob a égide de um projeto maior, o de constituição de um sistema público e universal de saúde, os ativistas do Movimento passaram a reunir esses gestores.

As primeiras reunióes dos secretários e dirigentes municipais de saúde no estado de São Paulo, por exemplo, foram incentivadas pelo ativista Nelson Rodrigues dos Santos, que, desde os anos 1970, fomentava a vertente municipalista do Movimento Sanitário. Foi como secretário de saúde em Campinas que ele promoveu as atividades no nível estadual:

Liguei para os secretários municipais e começamos a nos organizar. Pegamos 17 cidades médias do estado de São Paulo e criamos um colegiado de secretários municipais de saúde. Esse colegiado começou a se reunir frequentemente, e elaboramos um projeto de municipalização. Todas as cidades médias, com seus deputados, prefeitos e a população foram pressionar o governo Montoro para municipalizar (Santos, 2008-2009, p. 651). 
Flavio Goulart, secretário de saúde de Uberlândia, no estado de Minas Gerais, sanitarista e sócio-fundador de duas organizações do Movimento pela Reforma Sanitária, do Centro Brasileiro de Estudos de Saúde (Cebes) e da Associação Brasileira de PósGraduação em Saúde Coletiva (Abrasco), foi um dos convidados da primeira reunião de São Paulo e, motivado pela iniciativa, reuniu alguns municípios vizinhos para um encontro semelhante em Minas. O Encontro dos Secretários de Minas Gerais ocorreu em 1984, em Araxá, ao qual se seguiram outros eventos nesse estado (Goulart, entrevista, 2012).

Na $8^{a}$ Conferência Nacional de Saúde, em 1986, maior mobilização do Movimento Sanitário até então que reuniu em Brasília mais de quatro mil pessoas, a vertente municipalista já apareceu, mas ainda sem projeção nacional. A comissão organizadora do evento, coordenada por um carismático ativista Sérgio Arouca, designou para os municipalistas apenas 12 vagas. No entanto, após a pressão e a insistência que Nelson Rodrigues dos Santos e Flávio Goulart fizeram junto à comissão, as vagas cresceram para mais de oitenta (Santos, entrevista, 2005). As atividades dos secretários e dirigentes municipais não constavam da programação oficial do evento, e sua reunião, sob a liderança de Nelson Rodrigues dos Santos (Goulart, entrevista, 2012), foi improvisada nas escadarias do local da Conferência. Lá se discutiu acerca da necessidade de fomentar as associações estaduais, bem como foi esboçada a possibilidade da fundação de uma entidade nacional.

No primeiro quadro observamos a emergência e organização da vertente municipalista do Movimento Sanitário, processo marcado do ponto de vista de interações socioestatais pela tática de ocupação de cargos em governos de oposição ao regime militar. Estes cargos constituem pontos de acesso ao Estado abertos ao Movimento em função das eleições e que permitiam a quem os ocupasse certo grau de influência no processo decisório. O encaixe se deu, portanto, entre militantes portadores de uma nova proposta 
de saúde e esses pontos de acesso. Nessa interação mutuamente constitutiva, por um lado, eram criadas as instituições setoriais de saúde e providos serviços municipais de saúde, e por outro, construía-se a rede informal entre indivíduos, grupos e organizações engajadas numa luta comum pela municipalização. A atuação de militantes no poder público forneceu oportunidades e recursos para a constituição do movimento.

\section{Ampliando a mobilização e grau de influência: a constituição do Conselho Nacional de Secretários Municipais de Saúde}

A partir de 1987, o Movimento Municipalista amplia sua busca pela influência, buscando encaixes nas instituições no nível federal e se engaja nas principais mobilizações do Movimento Sanitário. O primeiro passo foi dado com a fundação da organização nacional. A forma organizacional assumida outorgava para si o papel de representação dos gestores do setor municipal de saúde diante do executivo federal e com base nisso foi possível reivindicar seu encaixe num dos importantes espaços de decisão política na época, na Comissão Interministerial de Planejamento (Ciplan).

O V Encontro do Setor Municipal de Saúde e IV Encontro dos Secretários Municipais de Saúde, realizados em março de 1987, em Londrina, reuniram cerca de mil pessoas num clima de intensos debates em torno da Constituinte. Os participantes desses eventos deliberaram a favor da constituição da entidade nacional dos secretários municipais de saúde e elegeram uma Comissão Provisória, composta por 14 membros de 12 estados, encarregada de organizá-la. Entre eles estavam vários ativistas do Movimento pela Reforma Sanitária tais como: Aparecida Linhares de Pimenta, Flávio Andrade Goulart, Júlio S. Muller Neto, Ricardo Nogueira, entre outros. A Comissão elaborou um documento intitulado "Proposta para a criação de um organismo nacional de secretários municipais de saúde", submetido à Organização Pan-Americana 
de Saúde (OPAS) e ao Ministério de Saúde, que o aprovaram. Numa reunião abrigada pela OPAS, em 10 de julho de 1987, na presença do secretário-geral do Ministério da Saúde (MS), do representante da OPAS, do secretário nacional de articulação com os estados e municípios, o Conselho Nacional de Secretários Municipais de Saúde (Conasems) foi declarado constituído, como uma associação civil sem fins lucrativos (Goulart, 1996, p. 45). No mesmo dia da reunião na OPAS, o ministro de Saúde recebeu a diretoria da nova organização, reconhecendo a entidade. Os ativistas do movimento acabavam de criar um formato organizacional que lhe facultava a representação do setor municipal de saúde, alinhado com o projeto da Reforma Sanitária, frente às autoridades federais. Mas a forma organizacional e reconhecimento das autoridades por si só não garantiam ao Conasems nenhum ponto de acesso nas instituições setoriais.

Os passos imediatos da diretoria e a comissão executiva do recém-fundado Conasems foram nesse sentido. No dia seguinte à constituição, a diretoria enviou a correspondência às outras autoridades federais e estaduais, comunicando a constituição do Conselho e reivindicando a representação do Conasems na Comissão Interministerial de Planejamento (Ciplan), órgão responsável pelo planejamento geral e pela programação das ações de saúde entre duas agências responsáveis pelo setor nacionalmente, o Ministério da Saúde e o Ministério da Previdência e Assistência Social. Sua presença no Ciplan foi confirmada, três meses depois, pela portaria interministerial n. 21, em 22 de outubro de 1987 (Goulart, 1996, pp. 45-46). O Conasems acabou de arquitetar seu encaixe no Estado.

Paralelamente, ocorrem a expansão e a formalização de sua estrutura organizacional de modo a viabilizar e garantir a representação. Os recursos do Ministério da Saúde, de algumas secretarias estaduais de saúde (RS, GO, MS, MG e RJ) e do convênio com a OPAS viabilizam as reuniões regulares da diretoria, não raramente 
realizadas no Congresso por causa do trâmite da lei que regulamentaria os preceitos constitucionais do novo sistema de saúde, tornando o Conasems o interlocutor quase obrigatório para os representantes do governo e os deputados (Medeiros, entrevista, 2012). O Conselho de Representantes, constituído por um representante para cada estado, foi estabelecido desde a fundação, ainda que apenas cinco associações estaduais estivessem constituídas. ${ }^{4} \mathrm{O}$ reconhecimento pelo Ministério teve a contrapartida financeira que resultou na liberação de recursos para as viagens continentais no esforço de montagem da estrutura federativa da organização. Mais seis associações foram constituídas por meio desse esforço entre os anos de 1989 e 1990 (Cosems-SP, 2008, p. 5), conformando 12 associações. Até 1994, 21 estados já contavam com as associações de secretários municipais instaladas.

A montagem das organizações estaduais e seu funcionamento evidenciam a protagonismo e a estratégia dos ativistas. As reuniões nos estados eram organizadas normalmente pelo secretário de saúde da capital, que convidava os secretários de outros municípios, entre os quais raramente se encontrava um militante da saúde pública, conforme evidencia o trecho da entrevista de Flávio Goulart, vice-presidente do Conasems na época (1988-1989):

secretário dos primórdios [do início do Conasems], era um médico, aliás raramente não era um médico, e como médico era um cara carregado de interesses. Era dono de hospital, ou sócio do hospital ou amigo dos donos do hospital. O que não impediu que tivesse gente com ideias boas, que queria fazer o sistema público avançar. Mas o nível de contradição era bem maior [do que hoje]. Tinha muitos secretários médicos defendendo os direitos dos médicos (Goulart, entrevista, 2012).

4 Essas associações foram criadas nos seguintes estados: em Pernambuco, Mato Grosso e Rio Grande do Sul, em 1986; no Pará e Paraná, em 1987 e em Paraíba e São Paulo, em 1988 (Cosems-SP, 2008, p. 5). 
Não é de se surpreender, portanto, que as associações estaduais tiveram, naquela época, um funcionamento mais fraco em comparação à sua filial nacional (Medeiros, entrevista, 2012). Para os ativistas do movimento tratava-se de constituir a representação formal que lhes permitisse falar em nome desse conjunto heterogêneo de ocupantes de cargos de secretárias municipais de saúde como defensores da Reforma Sanitária. O contraexemplo, o de uma associação estadual ativa, foi o caso da Associação dos Secretários Municipais de Saúde (Asems) de São Paulo "Dr. Sebastião Moraes", ilumina a dinâmica do funcionamento inicial: o engajamento dos sanitaristas. Entre os quadros dirigentes da Asems de São Paulo estavam vários dos militantes do movimento, entre os quais: Aparecida Linhares Pimenta, David Capistrano Filho, Fernando Galvanese, Gastão Wagner, Gilson Carvalho, José Ênio Servilha Duarte. Fundada em 1988, a Associação "[n]os primeiros anos só existia graças ao trabalho militante de um grupo muito reduzido dos secretários municipais que acreditavam na proposta de municipalização" (Linhares apud Cosems-SP, 2008, p. 12). Da mesma maneira como ocorria no nível nacional, a associação organizava os encontros estaduais nas cidades em que as secretarias estavam ocupadas pelos militantes, como exemplificam as cidades paulistas: São Bernardo do Campo, Bauru, Santos, Piracicaba e Campinas. Os encontros contavam com centenas de participantes, inclusive com a presença dos secretários e diretores de saúde e constituíam-se como palcos de debate, troca de informações e experiências (Cosems-SP, 2008, p. 13). Um dos principais temas dos encontros naqueles primeiros anos era a apresentação e a divulgação de informações sobre a municipalização, que para muitos constituía ainda uma "caixa-preta", enquanto para os sanitaristas tratava-se de uma realidade em curso havia mais de dez anos.

A municipalização gerava muito polêmica, como expressa o presidente do Cosem-SP: 
Muitos secretários estavam mais preocupados com a substituição de cargos a tarefas [...] Houve muita polêmica em relação aos sindicatos de médicos, de trabalhadores e associações, porque a municipalização foi afobada, neste aspecto... Os profissionais foram municipalizados sem treinamento, sem unificação de salários e, no começo, foi tudo bastante tumultuado (Gastão apud Cosems-SP, 2008, p. 15).

Na gestão do sanitarista Gilson Carvalho (1991-1992), as reuniões eram organizadas inclusive por macrorregiões para chegar mais próximos aos municípios e secretários:

Tínhamos que mobilizar os secretários municipais de Saúde do Estado para que aderissem ao SUS e para que fossem capazes de assumir seus papéis, na construção do SUS. Aquele foi um momento importante que exigiu muito esforço dos dirigentes [do Cosems-SP]. (Carvalho apud Cosems-SP, 2008, p. 24).

$\mathrm{Na}$ sua gestão, Gilson Carvalho editava semanalmente o boletim do Cosems-SP, denominado SOS Saúde. Esse informativo era encaminhado via fax para os secretários municipais engajados, os quais, por suas vezes, reproduziam-no para os municípios de suas regiões, constituindo uma rede de informações. Eram divulgados também os documentos técnicos para politizar os secretários municipais, informações administrativas, de financiamento, gestão e gerência de saúde, contabilidade entre outros.

A formalização organizacional no nível nacional e o encaixe no Estado por meio da participação no Ciplan não impediram a mobilização da vertente contra as ameaças ao recém-instituído SUS. O trâmite da Lei Orgânica de Saúde (LOS), regulamentadora dos preceitos constitucionais do novo sistema de saúde no Brasil, colocou o Movimento pela Reforma Sanitária novamente no Congresso. O Poder Executivo teve um prazo de seis meses, a 
partir da promulgação da Constituinte, para mandar ao Congresso o projeto da LOS. No entanto, não o fez, pressionado por diversos grupos com interesses privados (Weyland, 1995). Um mês após o prazo estipulado, o movimento organizou seu VI Simpósio sobre a Política Nacional de Saúde, em maio de 1989, que encheu os corredores do Congresso com centenas de pessoas, mostrando a força numérica do movimento (Santos apud Brasil/MS/Segep, 2006, p. 132). O relatório do Simpósio continha os artigos da LOS, que haviam sido elaborados pelo Núcleo de Estudos de Saúde Pública da Universidade de Brasília, dirigido pelo ativista Eleutério Rodrigues Neto (Barros, entrevista, 2009).

O Conasems se integrou junto com outros atores à mobilização do movimento para pressionar a favor da aprovação da lei. Seus integrantes acompanharam o processo da tramitação do projeto da lei dentro do Congresso até a sua aprovação, promovendo as reuniões de caráter mobilizatório no Congresso (Medeiros, entrevista, 2012) e recorrendo à tática das reuniões com as lideranças no Congresso e pressão junto aos parlamentares (Carvalho, entrevista, 2012). Eduardo Jorge, sanitarista que se elegeu deputado federal pelo voto do Movimento Popular de Saúde que ele próprio ajudou a organizar nos anos 1970, lança uma explicação do funcionamento da pressão da "base eleitoral" junto aos deputados em comparação à tática dos protestos:

Os deputados que eram contra eram 'buscados', para que a Plenária pudesse, ao mesmo tempo, adicionar um elemento de pressão efetiva, para o deputado saber que na base dele tinha gente articulada, gente preparada, gente com a argumentação capaz de criticá-lo. O deputado não tem medo de manifestação genérica, se a base de lá de Pernambuco, do Paraíba, do Amapá, não é muito afetada. Ele é imune, resistente à pressão desse tipo, salvo a movimentos muito grandes como o Diretas Já, o impeachment, que vira uma coisa em que ninguém está a salvo da pressão. [...] 
Mas, quando o deputado federal, por exemplo, lá do Ceará, recebia a visita do deputado estadual, do vereador, dos secretários municipais do interior do Ceará, ele prestava atenção na coisa, porque sabia que isso tinha repercussão na sua cidade, na sua base. Então esse elemento qualitativo do movimento foi importante porque serviu para diminuir as resistências, amenizar a oposição que a gente tinha no setor (Jorge Sobrinho apud Brasil/MS/ Segep, 2006, p.135; destaques nossos).

Outros atores do setor também estavam exercendo pressão sobre o Congresso. O setor privado fazia o lobby, e a burocracia do Inamps, refratária ao processo da descentralização que colocava em xeque a sua atuação, elaborou o seu próprio projeto de lei, impedindo a descentralização (Weyland, 1995, p. 1708). Cada artigo foi objeto de disputa acirrada e exigia a atenção e a presença contínua do movimento (Silveira Neto, entrevista, 2005). A Lei 80.80 , correspondente ao projeto do movimento, foi aprovada pelo Congresso, mas, submetida à aprovação do presidente Collor, sofreu uma série de vetos.

Dos vetos do presidente Fernando Collor à Lei Orgânica da Saúde, dois são os mais lembrados: o veto às Conferências Nacionais e aos Conselhos e o veto à transferência direta, regular e automática dos recursos aos estados e munícipios sem a necessidade de celebrar convênios. Nas palavras de um dos militantes do movimento, com os vetos, "a LOS nascia descabeçada”, na medida em que se retiravam dela duas das três diretrizes constitucionais, quais sejam, a participação da comunidade e a descentralização ${ }^{5}$ (Brasil, 1988, art. 198), guias do projeto do Movimento pela Reforma Sanitária. Fernando Collor tornava evidente a sua posição política em relação à participação da sociedade civil organizada

5 O terceiro, embora não nessa ordem, era o "atendimento integral, com prioridade para as atividades preventivas, sem prejuízo dos serviços assistenciais” (Brasil, 1988, art.198). 
nas políticas públicas, ao impedir a constituição das instituições participativas. Ao anular as transferências diretas, centralizava o poder no nível federal, mantendo o controle sobre os recursos e impedindo a autonomia dos municípios no setor.

Os vetos de Collor não significavam a impossibilidade do diálogo com o poder Executivo. O movimento, cujas diversas organizações estavam reunidas na época em torno da Plenária Nacional de Saúde, recorreu à tática de negociações junto ao então ministro da Saúde, Alceni Guerra, médico e funcionário do Inamps sem vínculos com o movimento. Conseguiu, por exemplo, uma audiência com o ministro, durante a qual explicitou sua capacidade de mobilizar e articular, tendo como resultado o consenso obtido no Congresso em torno da LOS, e solicitava ao ministro o comprometimento de não alterar nada que estava dentro da lei no momento da aprovação pelo presidente (Drummond, entrevista, apud Brasil/MS/Segep, 2006, p. 132). Apesar da promessa, o então presidente do Conasems, Eri Medeiros, lembra que o ministro convocou uma reunião com os atores do Movimento pela Reforma Sanitária, informando-lhes acerca dos vetos do presidente, antes que a notícia se tornasse pública.

Os atores se colocaram em posição de uma possível mobilização. $\mathrm{O}$ Conasems reuniu suas associações estaduais, que decidiram lançar uma mobilização para derrubar os vetos, anunciada no bimensal jornal do Conasems, o Presença Conasems, editado em cem mil exemplares, publicado em setembro de 1990. No editorial, o repertório de ação estava posto: "Na crise, mobilização e negociação". Os secretários ligados à causa da Reforma Sanitária deslocavam-se para Brasília, faziam reuniões internas com vistas à articulação, pressionavam o Ministério da Saúde e as lideranças parlamentares. Eram muitos, representavam uma diversidade de munícipios e, entre esses, também os de grande porte, o que lhes garantia força política. Eram pluripartidários, o que lhes permitia, com efeito, acionar uma diversidade de partidos. 
Independentemente do partido de filiação e do tamanho do município, os secretários ligados ao Conasems estavam mobilizados: "A gente chegava a passar quinze dias em Brasília. Meu município que era mais rico me dava a diária e no meu quatro de hotel dormiam quatro ou cinco secretários que vinham dos municípios sem recursos" (Carvalho, entrevista, 2012).

O Congresso estava pronto para derrubar os vetos do presidente, mas o canal de negociação estabelecido com o ministro da Saúde deu origem a outra solução, que evitou a derrota de Collor no Congresso - ponto defendido por seu ministro nas negociações com os atores do movimento. A solução passou pela elaboração de uma nova lei que contemplasse dois princípios indispensáveis ao movimento e vetados por Collor. Sua confecção ficaria por conta dos atores do movimento, que receberiam, para tanto, um recurso mediante o convênio que o Ministério firmou com o Conasems. Esse encontro aconteceu no feriado do dia 15 de novembro de 1990, reunindo as principais organizações do Movimento pela Reforma Sanitária como o Conasems, o Centro Brasileiro de Estudos de Saúde (Cebes), a Associação Brasileira de Pós-Graduação de Saúde Coletiva (Abrasco) e vários ativistas do movimento (Brasil/MS/Segep, 2006, p. 134). O projeto de lei seguiu ao Ministério da Saúde para que o Poder Executivo pudesse apresentá-lo ao Congresso.

No início de dezembro de 1990, Alceni Guerra mandou um emissário de Brasília a Fortaleza, onde estavam reunidos os participantes do VI Encontro Nacional dos Secretários de Saúde ali realizado, no período de 9 a 12 de dezembro de 1990. O emissário do Planalto entregava ao coletivo a cópia do ofício assinado pelo presidente Collor, por meio do qual ele encaminhava ao Congresso a proposta da lei elaborada pelo movimento no feriado da República (Carvalho, entrevista, 2012; Medeiros, entrevista, 2012). A negociação no Congresso foi rápida. A Lei Orgânica de Saúde n.8.142, que revertia os dois vetos do presidente Collor à LOS 80.80, foi 
aprovada pelo Congresso em 28 de dezembro de 1990, sem a votação no Plenário, por acordo entre as lideranças partidárias.

Em suma, a vertente municipalista optou por erguer e formalizar uma organização nacional de representação de modo a poder montar seu encaixe em uma instância decisória permeável aos atores de fora da administração pública federal. Este encaixe tornava o acesso ao Estado em parte independente das eleições. Concomitantemente à participação do Ciplan, foram organizadas mobilização e pressão do Conasems junto a outros atores do Movimento pela Reforma Sanitária no processo decisório que afetava o projeto do Movimento. Os processos de institucionalização e mobilização corriam em paralelo.

\section{Construindo seus próprios pontos de acesso ao Estado: em busca da permanência nos processos decisórios}

No cambiante contexto das instituições no setor de saúde com a instalação do novo Sistema Único de Saúde (SUS), caducavam alguns espaços de negociação, enquanto outros eram instituídos. A instância de negociação intragovernamental, a Ciplan, da qual o Conasems fazia parte, deixava de existir, enquanto o Conselho Nacional de Saúde (CNS), antes meramente consultivo, ganhava o poder deliberativo e uma composição mais heterogênea e diversificada em relação ao seu antecedente. Era um momento no qual os pontos de acesso no Estado estavam mudando, e atores organizados como o Conasems podiam interferir nesse processo. Aproveitando o momento de mudanças no desenho institucional, os ativistas arquitetaram dois novos pontos de acesso que tornaram sua presença mais contínua ao Estado no nível federal: garantiram o lugar fixo para o Conasems no Conselho Nacional de Saúde e criaram uma nova instituição capaz de interferir no processo de decisão sobre a municipalização. 
O Conasems, junto com o Conselho Nacional de Secretários Estaduais de Saúde (Conass), (este presidido entre os anos de 1989 e 1990 pelo municipalista Nelson Rodrigues dos Santos), obteve êxito na aprovação de um artigo na Lei Orgânica de Saúde, o qual estabelecia a representação nominal de suas entidades na composição do Conselho Nacional de Saúde, o que configurava o encaixe, tendo em vista a representação nominal. Depois dos vetos do presidente, o projeto de lei que repunha dois dos artigos vetados, elaborado, como vimos, pelo Movimento, recolocava também a representação das duas entidades no Conselho, do qual fariam parte também, discriminados genericamente, representantes do governo, prestadores de serviço, profissionais de saúde e usuários. Ainda que precisasse da homologação pelo ministro da Saúde para tornar as decisões efetivas, o novo Conselho possuía o poder de deliberação. Foi a partir dessa atribuição que os ativistas garantiram a presença do Conasems no Conselho, configurando um encaixe independentemente das eleições para essa instância.

$\mathrm{Na}$ primeira reunião do Conselho Nacional de Saúde, o então presidente do Conasems apresentou um ponto de pauta: a discussão sobre a criação de uma comissão intragovernamental que colocasse juntos os três níveis federativos para debater e tomar decisões relativas à gestão descentralizada do SUS. Fariam parte dela os representantes do MS cujo perfil dependeria do ocupante do cargo de maior poder no Ministério, ou seja, de caráter contigencial, e de representantes de duas associações, o Conass e o Conasems, que não dependiam do jogo eleitoral, na medida em que essas associações elegiam seus representantes internamente.

A proposta levada pelo presidente do Conasems havia sido elaborada por iniciativa dos sanitaristas Nelson Rodrigues dos Santos e Gilson Carvalho - ambos militantes da vertente municipalista - com a ajuda de dois engajados juristas, Guido Carvalho e Lenir Santos. A recomendação do CNS legitimaria o espaço que visava a institucionalizar a influência do Conasems e do Conass no 
processo decisório do nível federal e torná-la imune às mudanças ministeriais a cada eleição.

O CNS em sua Resolução n.2, de 26 de março de 1991, recomendava ao Ministro da Saúde a criação de:

uma Comissão Especial visando discutir e elaborar propostas para a implantação e operacionalização do SUS constituída pelas três instâncias gestoras públicas, União pelo Ministério da Saúde, Secretarias Estaduais de Saúde pelo Conselho Nacional de Secretários Estaduais de Saúde (Conass) e Secretarias Municipais de Saúde pelo Conselho Nacional de Secretários Municipais de Saúde com a incumbência de desenvolver esta relação entre as três esferas de governo, com o compromisso que esta Comissão apresente seus resultados ao CNS.

A Resolução do CNS seria homologada pelo ministro da Saúde, em julho de 1991, pela portaria n.1.180, mas a Comissão ficou inativa até o momento em que o representante do Conasems, o sanitarista Gilson Carvalho, assumiu o cargo de secretário do SUS, no Ministério da Saúde, já no governo de Itamar Franco (1992-1994). Seu desenho, denominação e função serão definidos pela Norma Operacional Básica 1993, um instrumento legislativo do Ministério de Saúde. A comissão foi batizada de Comissão Intergestores Tripartite (CIT) e teve os seus equivalentes estaduais, as Comissões Intergestores Bipartite (CIB), e todas elas constituirão, junto com o CNS, "foros de negociação e deliberação" do gerenciamento do processo de descentralização do SUS (NOB, 1993). ${ }^{6}$

6 Sua relevância nos estados dependerá dos Conselhos Estaduais de Secretários Municipais de Saúde e de a sua pressão junto às Secretarias Nacionais de Saúde para convocá-las e, no nível federal, do perfil do ministro de Saúde (Arretche, 2005). 
A capacidade de influência no processo da descentralização por meio desse ponto de acesso ao processo decisório, como o era a CIT, variará de acordo com o ocupante do Ministério da Saúde e não poderia prevenir a centralização do poder decisório pelo Ministério durante o governo de FHC (Arretche, 2005). A CIT precisava de um maior grau de institucionalização e foi com essa compreensão que os municipalistas empreenderam uma ação para inscrever a CIT e as CIBs na Lei Orgânica de Saúde. Com isso deixava de ser fruto de uma portaria ministerial que podia ser desativada ou revogada a qualquer momento.

Em 25 de agosto de 2011, a Lei Orgânica de Saúde, a histórica Lei 80.80 , sofria dois acréscimos no seu artigo 14, que elevavam o grau de institucionalização do Conasems e de sua configuração de encaixes. O primeiro acréscimo admitia o Conasems como a entidade representativa dos entes municipais em matérias referentes à saúde e declarava-o de utilidade pública e de relevante função social, na forma de regulamento (art.14-B), garantindo os recursos do Fundo Nacional de Saúde para o custeio das suas despesas e autorizando a celebração dos convênios. Os Cosems - as associações estaduais de secretários - foram reconhecidos como entes representantes dos municípios, desde que vinculados institucionalmente ao Conasems. O segundo reconhecia a CIT e a CIB como foros de negociação e pactuação entre gestores quanto aos aspectos operacionais do Sistema Único de Saúde (art. 14-A). Essa configuração de encaixes outorgava ao Conasems alta capacidade de agir nos processos decisórios que diziam respeito à matéria de descentralização e municipalização, caracterizando o domínio de sua agência com relação a esses temas.

Em resumo, nesse terceiro quadro, observado no nível federal, o movimento municipalista buscou uma configuração de encaixes que lhe permitiria o acesso privilegiado aos processos decisórios. Este é o caso da cadeira cativa no Conselho Nacional de Saúde que independe das eleições para esse órgão, bem como 
as novas instituições - a CIT e as CIBs - onde o Conasems teve a presença garantida e que foram elevadas ao estatuto do espaço de negociação por excelência e por obrigação legal da implementação do SUS. Embora os representantes de governo variem nelas de acordo com as eleições, os cargos ocupados pelo Conasems não dependem das eleições e da composição da coalizão presidencial. A atribuição de utilidade pública e o status de representante do setor municipal de saúde garantem interlocução privilegiada e permanente com níveis estaduais e federal de governo. A inclusão desses elementos na Lei Orgânica assegura maior grau de institucionalização e, portanto, de estabilidade. As incertezas decorrentes dos resultados do jogo eleitoral no que se refere ao acesso a processos decisórios foram minimizadas.

\section{Conclusão}

Ainda que não necessariamente revolucionários, os objetivos e as reivindicações de movimentos sociais carregam o questionamento do status quo que raramente depende de uma tomada de decisão. Seus projetos, mesmo quando finalmente transformados em leis e políticas públicas, nunca estão totalmente seguros contra as mudanças que o jogo eleitoral democrático proporciona. Os movimentos têm à sua disposição o repertório confrontacional bem como aquelas ações que se dão nas e por meio das instituições. A escolha vai depender da legitimidade que essas táticas possuem para os ativistas e suas organizações bem como dos recursos ao seu dispor. As ações via instituições significam certa compreensão do sistema político e, além disso, podem desencadear processos de institucionalização que garantam influência prolongada nos processos decisórios por meio de encaixes dos atores nos pontos de acesso abertos pelo Estado e por que não deixem sua atuação independente do processo eleitoral. 
Como os movimentos se protegem contra as incertezas que habitam os processos políticos? Em primeiro lugar, o caso empírico apresentado mostra que os atores enxergam a impermanência do e no poder e reagem contra ela. Fazem-no buscando se encaixar nos pontos de acesso aos processos decisórios que tornam sua influência mais permanente e estável. Os sanitaristas constituíram a associação nacional dos secretários para poder reivindicar o encaixe na instância de planejamento do nível federal. Alguns pontos de acesso já existem no Estado e neles os encaixes precisam ser arquitetados; mas é também possível construí-los. $\mathrm{O}$ exemplo da CIT e das CIBs evidencia a engenharia institucional e estratégica dos ativistas do movimento. Ao criar uma nova instituição à qual têm acesso garantido por lei e ao adquirir para sua organização o estatuto de utilidade pública, os atores do movimento se protegem ao menos parcialmente das incertezas do jogo eleitoral. Ainda que se possa discutir o grau de influência dessas novas instituições, elas permanecem no tempo como parte do Estado. Se esse processo de institucionalização significou o fim do movimento enquanto um tipo de dessa ação coletiva, ao mesmo tempo não extinguiu a ação coletiva em si. Transformou-a nessa forma híbrida, meio Estado meio sociedade civil.

\section{REFERÊNCIAS}

ABERS, Rebecca; SERAFIM, Liza; TATAGIBA, Luciana. Repertórios de interação Estado-sociedade em um Estado heterogêneo: a experiência na era Lula. Dados, 2014, v. 57, n. 2, pp. 325-357. Disponível em: <http://dx.doi. org/10.1590/0011-5258201411>.

ABERS, Rebecca; VON BÜLOW, Marisa. Movimentos sociais na teoria e na prática: como estudar o ativismo através da fronteira entre Estado e sociedade? Sociologias, 2011, n. 28, pp. 52-84. Disponível em: <http://dx.doi. org/10.1590/S1517-45222011000300004>. 
ARRETCHE, Marta. A política da política de saúde no Brasil. In: Lima, Nísia Trindade et al. (Ed.) Saúde e democracia: história e perspectivas do SUS. Rio de Janeiro: Ed. Fiocruz, 2005, pp. 285-306.

BRASIL. Constituição da República Federativa do Brasil. Brasília: Senado Federal, 1988.

BRASIL/MS/SEGEP. Ministério da Saúde. Secretaria de Gestão Estratégica e Participativa. A construção do SUS. Histórias da Reforma Sanitária e do Processo Participativo. Brasília: Ed. do Ministério da Saúde, 2005.

CAPISTRANO FILHO, David; PIMENTA, Aparecida L. Saúde para todos: um desafio ao municipio. São Paulo: Hucitec, 1988.

CARLOS, Euzeneia. (2015), Movimentos sociais e instituições participativas: efeitos do engajamento institucional nos padrões de ação coletiva. Revista Brasileira de Ciências Sociais, 2015, v. 30, n. 88, pp. 83-99. Disponível em: < http// dx.doi.org/10.17666/308883-98/2015>.

CONASEMS. Conselho Nacional de Secretarias Municipais de Saúde. Movimento sanitário brasileiro na década de 1970: a participação das universidades e dos municípios. Brasília: Conasems, 2007.

CONASEMS. Conselho Nacional de Secretarias Municipais de Saúde. Conasems: 15 anos! 2003. Disponível em: <http://bvsms.saude.gov.br/bvs/publicacoes/historia_conasems.pdf >. Acesso em: 17 set. 2012.

COSEMS-SP. Conselho de Secretários Municipais de Saúde do Estado de São Paulo. SUS e Cosems-SP: da Constituinte 88 ao Pacto pela Saúde, 20 anos. São Paulo: Cosems-SP, 2008.

DIANI, Mario. Introduction: Social Movements, Contentious Actions, and Social Networks: 'From Metaphor to Substance'? In: Diani, Mario; McAdam, Doug (Ed.). Social Movements and Networks: Relational Approaches to Collective Action. Oxford: Oxford University Press, 2003, pp. 1-18.

DOWBOR, Monika. A arte da institucionalização: estratégias de mobilização dos sanitaristas (1974-2006). Tese (Doutorado em Ciência Política) - Universidade de São Paulo, São Paulo, 2012. Disponível em: <http://dx.doi.org/10.11606/T.8.2012.tde-06032013-111003>.

ESCOREL, Sarah. Reviravolta na saúde: origem e articulação do movimento sanitário. Rio de Janeiro: Ed. Fiocruz, 1998. 
ESCOREL, Sarah; BLOCH, Renata A. As Conferências Nacionais de Saúde na construção do SUS. In: Lima, Nisia Trindade et al. (Ed.). Saúde e democracia: história e perspectivas do SUS. Rio de Janeiro: Ed. Fiocruz, 2005, pp. 83-119.

FALLETI, Tulia. Inflitring the State: The Evolution of Health Care Reforms in Brazil, 1964-1988. In: Mahoney, James; Thelen, Kathleen. Explaining Institutional Change: Ambiguity, Agency and Power. New York: Cambridge University Press, 2010.

GAMSON, William. The Strategy of Social Protest. Belmont, CA: Wadsworth, 1990.

GIUGNI, Mario. Was it Worth the Effort? The Outcomes and Consequences of Social Movements. Annual Review of Sociology, 1998. v.24, pp. 371-393.

GIUGNI, Mario. Political, Biographical, and Cultural Consequences of Social Movements. Sociology Compass, 2008, v. 2-5, pp. 1582-1600. Disponível em: <http://dx.doi.org/10.1111/j.1751-9020.2008.00152>.

GIUGNI, Marco; YAMASAKI, Sakura. The Policy Impact of Social Movements: A Replication Through Qualitative Comparative Analysis. Mobilization, 2009, v. 14, n. 4, pp. 467-484. Disponível em: <http://mobilizationjournal.org/doi/abs/10.17813/maiq.14.4.m2w21h55x5562r57>. Acesso em: 10 abr. 2016.

GOULART, Flávio A. Municipalização: Veredas: caminhos do movimento municipalista de saúde no Brasil. Rio de Janeiro, Abrasco/Conasems, 1996.

MAHONEY, James; THELEN, Kathleen. A Theory of Gradual Institutional Change. In: Mahoney, James; Thelen, Kathleen (Ed.). Explaining Institutional Change: Ambiguity, Agency, and Power. New York: Cambridge University Press, 2010.

MARQUES, Eduardo. Redes sociais e poder no Estado brasileiro: aprendizados a partir de políticas urbanas. Revista Brasileira de Ciências Sociais, 2006, v. 21, n. 60, pp. 15-41. Disponível em: <http://dx.doi.org/10.1590/S010269092006000100002>.

MCADAM, Doug. Conceptual Origins, Current Problems, Future Directions. In: McAdam, Doug; McCarthy, John; Zald, Mayer (Ed.), Comparative Perspectives on Social Movements. Political Opportunities, Mobilizing Structure, and Cultural Framings. Cambridge: Cambridge University Press, 2006. 
MCADAM, Doug; TARROW, Sidney. Movimentos sociais e eleições: por uma compreensão mais ampla do contexto político da contestação. Sociologias, 2011, v. 13, n. 28, pp. 18-51.

MEYER, David; TARROW, Sidney. A Movement Society: Contentious Politics for a New Century. In: Tarrow, Sidney; Meyer, David (Ed.). The Social Movement Society: Contentious Politics for a New Century. Lanham, MA: Rowman and Littlefield, 1998.

POSSAS, Cristina de A. Saúde, medicina e trabalho no Brasil: uma antropofagia do capitalismo selvagem. Dissertação (Mestrado em Antropologia Social) - Universidade Estadual de Campinas, Campinas, 1980.

SANTOS, Nelson R. dos. Entrevista com Nelson Rodrigues dos Santos. Revista Trabalho, Educação e Saúde, 2008-2009, v. 3, n. 3, pp. 645-658.

SILVA, Marcelo K.; OLIVEIRA, Gerson. A face oculta(da) dos movimentos sociais: trânsito institucional e intersecção Estado-Movimento: uma análise do Movimento de Economia Solidária no Rio Grande do Sul. Sociologias, 2011, ano 13, n. 28, pp. 86-124.

SILVEIRA NETO, Crescêncio A. Crescêncio Silveira Neto: depoimento [24 fev. 2005]. Entrevistador: Luiz Carlos Fadel de Vasconcelos. In: Brasil. Ministério da Saúde. Secretaria de Gestão Estratégica e Participativa. A construção do SUS: história da Reforma Sanitária e do Processo Participativo. Brasília: Ministério da Saúde, 2006, p. 11.

TATAGIBA, Luciana. Desafios da relação entre movimentos sociais e instituições políticas. O caso do movimento de moradia da cidade de São Paulo: primeiras reflexões. Colombia Internacional, 2010, v. 71, pp. 63-83.

TILLY, Charles. Social Movements, 1768-2004. Boulder, CO: Paradigm Publisher, 2004.

WEYLAND, Kurt. Social Movements and the State: The Politics of Health Reform in Brazil. World Development, 1995, v. 23, n. 10, pp. 1699-1712. Disponível em: <www.utexas.edu/cola/files/275345>. Acesso em: 15 ago. 2012.

\section{ENTREVISTAS}

BARROS, Elisabeth. Elisabeth Barros, sanitarista: depoimento [3 dez. 2009]. Entrevistadora: Monika Dowbor. Entrevista concedida para pesquisa de doutorado da entrevistadora. 
CARVALHO, Gilson. Gilson Carvalho: depoimento [15 maio 2012]. Entrevistadora: Monika Dowbor. Entrevista concedida por Skype, para pesquisa de doutorado da entrevistadora.

GOULART, Flavio. Flavio Goulart, sanitarista: depoimento [8 maio 2012]. Entrevistadora: Monika Dowbor. Entrevista concedida por Skype, para pesquisa de doutorado da entrevistadora.

MEDEIROS, José Eri Osório de. José Eri Osório de Medeiros, sanitarista: depoimento [24 maio 2012]. Entrevistadora: Monika Dowbor. Entrevista concedida por Skype, para pesquisa de doutorado da entrevistadora. 


\section{Capítulo 2}

\section{A ENTRADA DOS NOVOS IMIGRANTES NA POlítica local de SÃo PAUlo: DOMÍNio DE AGÊNCIA E DISPUTA PARTIDÁRIA ${ }^{1}$}

Patrícia Tavares de Freitas ${ }^{2}$

'A situação é de medo, principalmente, entre os paraguaios e os bolivianos', afirma o padre da Pastoral do Migrante [...]. 'É compreensível', pondera o padre Geremia, 'A polícia os pisa e os despachantes os logram. Não têm motivos para depositar confiança nas instituições'. O pouco contato mantido com os bolivianos dá-se no centro de acolhimento da organização, a

1 Neste artigo serão expostos alguns dos resultados de pesquisa desenvolvida entre 2014 e 2016, no âmbito do programa de pós-doutorado do Centro de Estudos da Metrópole (CEM), com financiamento da Fundação de Amparo à Pesquisa do Estado de São Paulo (Fapesp), sob orientação do professor Dr. Adrian Gurza Lavalle, do Departamento de Ciência Política da Universidade de São Paulo (DCP/USP). A pesquisa empírica baseia-se em observação participante e 33 entrevistas em profundidade com representantes da sociedade civil e dos governos municipal e estadual envolvidos com a defesa de direitos, recepção e integração dos novos imigrantes na cidade de São Paulo. Trata-se de pesquisa que dá continuidade a uma trajetória de estudos sobre as novas migrações internacionais (em especial, a migração boliviana vinculada ao trabalho na indústria de confecção da cidade). Nesse sentido, paralelamente à elaboração de dissertação de mestrado (Freitas, 2009) e tese de doutorado (Freitas, 2014c), publiquei os seguintes artigos sobre a temática: Freitas, 2014a, 2014b, 2013a, 2013b, 2011, 2012 e 2010. Este artigo, ao mesmo tempo, inaugura nova agenda de pesquisa a partir dos diálogos e debates com os pesquisadores do Núcleo de Democracia e Ação Coletiva (NDAC), do Centro Brasileiro de Análise e Planejamento (Cebrap). Ver os artigos Freitas, 2016a e 2016b.

2 A autora agradece financiamento da Fundação de Amparo à Pesquisa do Estado de São Paulo (Fapesp), por meio de bolsa de pós-doutorado, realizado no CEM, processo no 2014/11649-0. As opiniões, hipóteses e conclusões expressas aqui são de responsabilidade da autora e não refletem necessariamente a visão da Fapesp. 
que recorrem diariamente cerca de dez imigrantes hispano-americanos recém-chegados, atraídos por um albergue com capacidade para 200 pessoas e pela esperança de alguma orientação (Folha de S. Paulo, 23 jul. 1989, "São Paulo é terra boa para quase $400 \mathrm{mil}$ ").

Imigrantes da Bolívia e de outros países vizinhos, como o Peru e o Paraguai, estão na mira dos candidatos em São Paulo e já influenciam no debate eleitoral da cidade. Dois dos principais candidatos a prefeito, Celso Russomano (PRB) e Fernando Haddad (PT) tiveram encontros com imigrantes e pelo menos dois candidatos a vereador querem se eleger tendo como base os latinos. [...] As principais bandeiras da comunidade são o combate ao preconceito e ao trabalho degradante, a garantia de um local para realizar as suas festas e a criação de uma secretaria específica para eles (Folha de S. Paulo, 27 ago. 2012, "Votos dos imigrantes sul-americanos são disputados em São Paulo”).

\section{Introdução}

Embora as duas notícias digam respeito à inserção latino-americana, na cidade de São Paulo, entre a primeira e a segunda, além da diferença dos tempos, por volta de duas décadas, destaca-se a diferença na abordagem e localização desses imigrantes no espaço social da cidade: de imigrantes isolados, afastados das instituições estatais, coagidos pela polícia e tutelados/amparados por uma entidade assistencial católica a atores políticos relevantes nas eleições municipais, com uma pauta de reivindicações disputada nos diálogos com os candidatos à prefeitura e à Câmara Municipal, 
com ressonância nos discursos de, pelo menos, seis candidatos a vereador, de partidos diferentes, nas eleições de $2012 .^{3}$

Com a vitória de Fernando Haddad, do Partido dos Trabalhadores (PT), nessas eleições, uma parte importante das reivindicações foi atendida pelo governo municipal, com o estabelecimento de: (i) uma estrutura institucional, no âmbito da Secretaria Municipal de Direitos Humanos e Cidadania, denominada de Coordenação de Políticas para Imigrantes (CPMig); (ii) cadeiras extraordinárias nos conselhos participativos das subprefeituras e, (iii) um abrigo e um centro de atendimento e encaminhamento profissional para essa população, o Centro de Referência e Acolhida do Imigrante (CRAI).

Alguns anos antes, em 2006, o então governador José Serra, do PSDB (Partido da Social Democracia Brasileira), havia instituído o Conselho Estadual para os Refugiados (CER), nas estruturas da Secretaria da Justiça e Defesa da Cidadania (SJDC), do governo estadual de São Paulo. Dois anos depois, foi estabelecido, na mesma secretaria, o Núcleo de Enfrentamento ao Tráfico de Pessoas $(\mathrm{NETP})^{4}$ e um comitê consultivo de apoio. ${ }^{5}$ Esse comitê foi substituído, em 2011, durante a gestão de Geraldo Alckmin, do PSDB, pela Comissão Estadual para a Erradicação do Trabalho Escravo (Coetrae). ${ }^{6}$ E, posteriormente, em 2015, foi inaugurado o Centro

3 Abel Fernandes, do PRB, Felipe Prado do PSC, Paulo Illes e Juliana Cardoso, do PT, Juscelino Gadelha, do PSB e Nilda Neves, do PCdoB, conforme apurou o site Bolivia Cultural, que acompanhou as eleições municipais da perspectiva do debate sobre a integração dos novos migrantes internacionais, em especial, da comunidade boliviana.

4 Instituído para a implementação do recém-aprovado Programa Estadual de Prevenção e Enfrentamento ao Tráfico de Pessoas (Pepetp).

5 Comitê Interinstitucional de Prevenção e Enfrentamento ao Tráfico de Pessoas (Cipetp).

6 Na prática, a questão dos novos imigrantes e refugiados, do trabalho escravo e do tráfico de pessoas passou a ser abordada conjuntamente, no interior da SJDC, a partir do Núcleo de Enfrentamento ao Tráfico de Pessoas (NEPT), a estrutura executiva. Nesse sentido, muitas vezes, por exemplo, as reuniões do CER e da 
de Integração da Cidadania do Imigrante, o CIC Imigrante, na SJDC, em parceria com a empresa Inditex. ${ }^{7}$

As estruturas institucionais indicadas acima conformam, no período atual, parte central do campo de interlocução sócio-estatal em torno dos imigrantes em situações de vulnerabilidade que começaram a chegar à cidade de São Paulo a partir dos anos $1980 .^{8}$

De maneira geral, trata-se de estruturas caracterizadas por mediarem (de maneiras diversas) as interaçôes sócio-estatais para além da esfera parlamentar (Isunza e Gurza Lavalle, 2013). Inserindo, sob múltiplos matizes e por meio de diferentes atores sociais e estatais, os novos imigrantes vulneráveis no cenário político local.

Tendo em vista fornecer um quadro compreensivo dos processos subjacentes à formação dessa diversidade de canais de interação sócio-estatal e de sua inserção no cenário político local da cidade de São Paulo, mobilizaremos, neste artigo, a perspectiva e os instrumentos analíticos propostos no debate brasileiro contemporâneo sobre os movimentos sociais, sociedade civil e participação,

Coetrae (comitês consultivos com representantes institucionais e da sociedade civil) - ambas sob responsabilidade executiva do NEPT - eram unificadas.

7 A empresa faz parte do grupo Zara e havia assinado um Termo de Ajuste de Conduta (TAC), devido a denúncias de trabalho escravo nas oficinas de costura subcontratadas pelo grupo. Essa parceria com a SJDC foi feita posteriormente como parte de uma ação global da empresa contra o trabalho escravo devido a denúncias realizadas em outras partes do mundo.

8 A literatura brasileira passou a denominar, em consonância com o debate internacional, as migrações pós anos 1980, como as "novas migrações internacionais" ou, ainda, os "novos fluxos migratórios". Embora o país (e, em especial, o estado de São Paulo) tenha sido importante receptor das migrações de massa europeias para o continente americano entre o final do século XIX e começo do século XX, essa tendência passou a ser revertida a partir dos anos 1930. Durante algumas décadas, entre os anos 1960 e 1980, o país foi considerado de população fechada (sem fluxos internacionais de entrada e saída relevantes). Sendo o contexto atual das migrações novo sob diversos aspectos, inclusive em relação às origens das populações recepcionadas (Assis, Sasaki, 2001; Baeninger, 2005; Patarra, 2005). No caso da cidade de São Paulo, a CPMig estima uma população de cerca de 370 mil novos imigrantes (Stefens e Martins, 2016, p. 275). 
no pós redemocratização (Dowbor, 2012; Carlos, 2012; Gurza Lavalle et al., 2012; Gurza Lavalle e Szwako, 2015; Houtzager, 2005; Isunza e Gurza Lavalle, 2013). Abordaremos os processos empíricos indicados acima a partir, especificamente, do debate sobre a formação de domínios de agência que articulam atores sociais e campos de políticas específicos (ver o capítulo de Gurza Lavalle, Carlos, Dowbor e Szwako, neste livro).

Em diálogo com o neo-institucionalismo histórico e com a macro-sociologia histórica comparada, inscrita no polity approach (Skocpol, 1992), ${ }^{9}$ a proposta analítica dos domínios de agência busca abarcar processos históricos de institucionalização, de médio alcance, de instâncias de atuação de atores sociais, que acabam por ampliar suas "capacidades de escolha, barganha e acordo diante do poder público e de outros atores organizados relevantes" (Gurza Lavalle et al., 2012, p. 187).

Conforme Gurza Lavalle, Carlos, Dowbor e Szwako, neste livro, os domínios de agência são constituídos por encaixes institucionais diversos, formados por meio de processos "de conflito, aprendizagem e cooperação" entre atores sociais e estatais. A cada encaixe logrado, abrem-se, de maneira seletiva para determinados segmentos da sociedade civil organizada, com poder e abrangência variados, canais de acesso ao Estado que, ao mesmo tempo, constituem novas capacidades estatais, mas também novos repertórios para os próprios atores sociais - perfazendo processos de mútua constituição sócio-estatal.

9 "The polity approach focuses on how societal and state actors are constituted, how they develop a differential capacity to act and form alliances, and how they cooperate and compete across the public-private divide to produce purposeful change. The capacity and nature of both State and societal actors are understood as the outcome of a two-way exchange that is shaped in substantial ways by the institutional terrain in which it takes place. The ability of political actors to produce a politic of inclusion is in large measure contingent to their ability to engineer fit with political institutions that grant some actors greater leverage in the policy process than others" (Houtzager, 2005, pp. 10-11). 
$\mathrm{Na}$ proposta analítica dos domínios de agência, esses diversos encaixes não devem ser considerados isoladamente, mas tendo em vista suas articulações historicamente arquitetadas com outros encaixes e atores. Essas articulações compõem configurações caracterizadas por qualidades de latitude e altitude. Enquanto a latitude nos remete à variação empírica dos encaixes e às articulações deles entre si (variação horizontal), a altitude nos remete às articulações dos encaixes com os demais atores e estruturas que compõem a hierarquia política da cidade e entre níveis de governo (variação vertical).

A estrutura analítica decorrente dessa perspectiva, proposta nesta pesquisa, é processual. Ou seja, considera que a explicação encontra-se na análise dos processos de desenvolvimento dos fenômenos em foco. Nesse sentido, propomos partir da identificação dos ciclos de interação sócio-estatal considerados relevantes para a formação do domínio de agência e dos encaixes institucionais principais, bem como da evolução dos atores sociais por entre os diversos encaixes, de 1980 a 2012, na cidade de São Paulo.

Neste capítulo, serão abordados três ciclos de interação sócio-estatal: pelo direito à educação dos imigrantes irregulares em oposição às determinaçóes do Estatuto do Estrangeiro, entre o final dos anos 1980 e a década de 1990. E, a partir dos anos 2000: os ciclos de interação sócio-estatal pela integração dos imigrantes no sistema básico de saúde e pelo direito à realização de atividades econômicas, culturais e políticas no espaço urbano.

O acompanhamento da evolução desses ciclos de interações sócio-estatais nos permite vislumbrar um processo de multiplicação e diferenciação dos atores sociais e a formação de um domínio de agência marcado por uma polarização interna que se cristaliza, no momento desta análise, em duas configurações com perfis distintos: 
1. um perfil estabelecido com base em uma articulação de encaixes concentrados, principalmente, nas estruturas executivas do governo estadual e em estreita ligação com políticos e gestores do PSDB. Da perspectiva da sociedade civil, esses encaixes são protagonizados por duas organizações católicas, a Pastoral do Migrante e o CAMI, por um lado, e pela Associação Gastronômica, Cultural e Folclórica Boliviana Padre Bento - Feira Kantuta, ${ }^{10}$ por outro; e

2. um perfil estabelecido a partir de uma articulação de encaixes concentrados, principalmente, nas estruturas executivas do governo municipal e em estreita ligação com políticos e gestores do PT. Da perspectiva da sociedade civil, esses encaixes são protagonizados por uma organização civil, o CDHIC (Centro de Direitos Humanos e Cidadania dos Imigrantes) e pela Associação dos Feirantes da Rua Coimbra. ${ }^{11}$

Este capítulo está dividido em três seções, ademais desta introdução. Na primeira seção, abordamos os momentos iniciais de constituição dos imigrantes como sujeitos sociais no espaço político da cidade, no pós-redemocratização, com base na consideração da formação do principal ator católico desse domínio de agência, a Pastoral do Migrante, e de sua atuação, durante os anos 1990, pelo direito à educação dos filhos de imigrantes indocumentados. Nesse momento, se constituem os primeiros encaixes institucionais na Secretaria de Justiça e Defesa da Cidadania (SJDC), do governo do estado de São Paulo, durante a gestão de Mario Covas, do PSDB.

10 Essa associação será denominada, neste artigo, de Associação Kantuta.

${ }^{11}$ Essa associação será denominada, neste artigo, de Associação Coimbra. 
$\mathrm{Na}$ segunda seção, acerca dos ciclos de interação sócio-estatal em curso durante a primeira década dos anos 2000, abordamos, por um lado, os processos de aproximação do governo municipal, durante a gestão de Marta Suplicy, do PT, dos imigrantes, em meio à adoção de novos instrumentos de gestão e de organização territorial da prefeitura, que possibilitaram o estabelecimento dos primeiros encaixes em algumas subprefeituras e na secretaria de saúde do município. E, por outro lado, a emergência de associações dos próprios imigrantes, a partir de embates, no espaço urbano, pela realização de atividades econômicas, culturais e políticas, que passaram a se fixar (por meio de articulações de encaixes específicas) em dois espaços da cidade - na praça Kantuta e na rua Coimbra.

$\mathrm{Na}$ terceira seção, retomaremos a caracterização dos dois perfis que compóem o domínio de agência em foco neste artigo, buscando indicar, com maior acuidade, a partir da narrativa desenvolvida nas seções anteriores, suas articulações horizontais e verticais.

\section{Novos atores no espaço sócio-político da cidade: os imigrantes de baixos recursos no pós redemocratização}

Todos os domingos, a Praça Padre Bento, em frente à imponente Igreja Santo Antônio do Pari, em São Paulo, se transforma no cenário de uma insólita atividade, uma evocação moderna dos mercados de escravos que funcionaram na cidade dos baróes do café até o século passado. Dezenas de imigrantes sul-americanos oferecem-se como força-de-trabalho para os coreanos que mantém oficinas de costura na cidade. As condições de trabalho pouco variam: jornada de 16 horas diárias e um cativeiro que só para da tarde de sábado à noite de domingo ( $O$ Globo, 13 dez. 1992). 
No período democrático contemporâneo, a questão dos novos imigrantes de baixos recursos adquire destaque na imprensa local, a partir, principalmente, de meados dos anos 1980, graças ao problema social do trabalho escravo dos latino-americanos em oficinas de costura espalhadas pela cidade. Multiplicam-se denúncias como a reproduzida acima, nas quais se indica a existência de circuitos de subcontratação de imigrantes, marcados por condições precárias de instalação nas oficinas de costura (nas quais os imigrantes moram e trabalham) e intensos regimes de trabalho (Azevedo, 2005; Buechler, 2004; Freire, 2008; Freitas, 2011; Côrtes, 2013). ${ }^{12}$

Nesse momento, destaca-se, como principal e quase exclusivo ator social envolvido no acolhimento e na politização da presença dos novos imigrantes na cidade, uma congregação católica scalabriniana que estabelece, nos anos 1970, a Pastoral do Migrante. Além da Pastoral do Migrante, a missão scalabriniana fundou a Casa do Migrante e o Centro de Estudos Migratórios. E, no mesmo período, seus padres fizeram parte da constituição do Serviço Pastoral do Migrante (SPM), vinculado à CNBB. Por atuarem em conjunto e possuírem a mesma localização, nos eventos considerados, essas instituições serão abordadas, ao longo deste artigo, na maioria dos casos, como apenas Pastoral ou Pastoral do Migrante.

O estabelecimento da Pastoral do Migrante - a princípio, voltada para o acolhimento e atuação política junto aos migrantes

12 Em relação às condições de instalação, denuncia-se o fato de a maioria das oficinas de costura não respeitar os padrões de higiene e de segurança mínimos definidos pelas legislações locais, estabelecendo-se em lugares pouco iluminados e pouco ventilados, onde, além de costurar, os imigrantes devem dormir e realizar suas refeições. E, em relação aos regimes de trabalho, denunciam-se as jornadas diárias de 15 horas ou mais, para o recebimento de remunerações inferiores às praticadas no mercado e, muitas vezes, pagas em espécie e não em dinheiro, ademais de situações de confinamento para o trabalho forçado e a presença de crianças e jovens submetidos a essas circunstâncias precárias e de intensa exploração laboral. 
internos e refugiados políticos latino-americanos e, posteriormente, a partir de meados dos anos 1980, para os novos imigrantes de baixos recursos e novos grupos de refugiados políticos e ambientais - ocorre em um momento marcado pelo recrudescimento do período militar no Brasil e pelo estabelecimento de uma orientação progressista na igreja católica. Durante o papado de João Paulo VI, o Concílio Ecumênico da Igreja Católica Vaticano II, proferido no Natal de 1961, marca o início dessa nova orientação. ${ }^{13} \mathrm{Na}$ Igreja latino-americana, a internalização das orientações do Concílio ocorreu durante a Segunda e a Terceira Conferências Gerais do Episcopado Latino-Americano - em Medelín, em 1968, e, em Puebla, em 1979, respectivamente (Iffly, 2010).

$\mathrm{Na}$ cidade de São Paulo, a aproximação com os migrantes internos e com os refugiados políticos latino-americanos ocorre graças ao envolvimento dos missionários na luta política pelo fim do regime militar e pela transformação das condições de vida das populações vulneráveis. Visando a colocar em prática a "opção pelos pobres", defendida pelo arcebispo dom Paulo Evaristo Arns, à época também à frente da Comissão Justiça e Paz (CJP), ${ }^{14}$ os missionários daquela organização pastoral se inseriram nas Comunidades Eclesiais de Base, no MOV (Movimento das Organizações Voluntárias pela Promoção do Favelado)

13 O Concílio Vaticano II, conforme explicita o padre Alfredo J. Gonçalves, em um documento do arquivo do padre Mario Geremias, disponível no CEM (Centro de Estudos Migratórios), denominado "Desafios da V Conferência Episcopal Latino-Americana", destaca-se pela "tentativa de diálogo com os problemas e desafios do mundo moderno".

14 A Comissão de Justiça e Paz de São Paulo foi criada em 1972, a princípio como parte da Igreja e subordinada ao organismo romano criado pelo papa Paulo VI. Após tornar-se uma organização civil, com maior autonomia, conforme desejava dom Paulo Evaristo Arns, passa a desempenhar um novo papel, com a realização das "primeiras tentativas de ações reivindicatórias na metrópole", em 1977. Destacando-se, desde os golpes na Argentina e no Chile, sua colaboração junto ao Alto Comissariado das Nações Unidas para Refugiados (Acnur), conforme analisa Iffly (2010, p. 97-100). 
e no movimento sindical. ${ }^{15}$ Esse envolvimento também aproximou os missionários de políticos e ativistas pelos direitos humanos que, posteriormente, fundariam os dois principais partidos do país do período democrático, o PT e o PSDB.

No início dos anos 1980, o Estatuto do Estrangeiro foi aprovado por decurso de prazo no Congresso Nacional. Em linhas gerais, esse Estatuto, baseado na doutrina de segurança nacional e na proteção do trabalhador nacional, passou a limitar os direitos sociais, políticos e civis dos novos imigrantes, por meio de uma gestão realizada pela Polícia Federal (PF) e pelo Conselho Nacional de Imigração (CNIg), vinculado ao Ministério do Trabalho.

Diante da restrição de direitos que, naquele momento, atingia indistintamente refugiados políticos e imigrantes econômicos, ${ }^{16}$ começaram a ser realizadas articulações entre a CJP e a Pastoral do Migrante em oposição a essa nova legislação nacional. Paralelamente, a colaboração da CJP junto à Agência da ONU para Refugiados, Acnur, acabou transformando a cidade em um pouso relativamente seguro para os refugiados políticos latino-americanos rumo, principalmente, a países da Europa e Estados Unidos. Circunstância que ensejou uma parceria ainda mais estreita com a Pastoral do Migrante, que auxiliou no acolhimento e no acompanhamento daqueles refugiados em São Paulo.

Após a abertura democrática, os atores e estruturas da Pastoral do Migrante passaram a se voltar ao acolhimento de outro grupo de imigrantes vulneráveis que chegava à cidade no período e se confundia, nos momentos iniciais, com os refugiados políticos que permaneceram no país: os imigrantes econômicos latino-americanos.

15 Uma expressão dessa aproximação, conforme indica Gonçalves (2005, p. 21), é a curiosidade de que o Estatuto de Fundação da CUT foi rodado no seminário daquela organização católica.

16 O Estatuto do Refugiado seria aprovado somente durante os anos 1990. 
Diante da manutenção do Estatuto do Estrangeiro e da atuação ostensiva da Polícia Federal (PF) em sua aplicação, a despeito da mudança constitucional, o trabalho com os latino-americanos (imigrantes econômicos e refugiados políticos de baixos recursos) realizado pela Pastoral incluía, de maneira central, em seus momentos iniciais, apoio jurídico e defesa dos imigrantes junto à $\mathrm{PF} .{ }^{17}$

Essa atuação da Pastoral desempenhava um papel-chave de mediação na relação entre os novos imigrantes e os atores estatais diretamente envolvidos em sua gestão. Perfazendo a principal voz dos novos imigrantes no cenário político da cidade, marcada pelo prestígio conquistado pelos padres católicos durante a ditadura militar, conforme podemos vislumbrar no depoimento abaixo:

Para os imigrantes, os padres são um respaldo. Eles têm espaço e têm poder. Na própria Polícia Federal, naquela época, nos anos [19]80 a coisa estava brava, por qualquer coisa você ia preso. E o padre Mário gritando e xingando os policiais lá. Chegava uma hora que o padre chegava e a polícia não se levantava para não o atender. Porque o padre tinha uma resposta para tudo, 'manjava' muito da parte jurídica, da parte legal. Então era difícil que o policial pudesse discutir com ele. Por isso que o imigrante se apoia em um padre. Porque eles têm um lugar e são bem vistos (Depoimento de imigrante apud Bomfim, 2010, s.p.).

Concomitantemente, durante os anos 1990, a Pastoral desenvolveu, junto aos latino-americanos, um trabalho de assistência social e integração sociocultural na cidade. Esse trabalho incluía visitas domiciliares e a abertura da igreja às celebrações comunitárias

${ }_{17}$ Defesa baseada nos direitos fundamentais (direito à vida, à liberdade, à igualdade, à segurança e à propriedade) e no princípio da dignidade da pessoa humana, garantidos para brasileiros e estrangeiros em território nacional pela Constituição de 1988. 
dos locais de origem, que anteriormente ocorriam no espaço privado da moradia desses imigrantes. ${ }^{18}$

Em meio ao início desse processo de construção identitária e política do novo grupo populacional na cidade, mediado pela Pastoral do Migrante, por um lado, e dos debates em torno do Estatuto da Criança e do Adolescente a ser aprovado no final dos anos $1990,{ }^{19}$ por outro, a Secretaria de Educação do Estado de São Paulo publica a resolução n. 9, em janeiro de 1990 (SE-09/90), impedindo que as escolas da rede estadual aceitassem matrículas de imigrantes indocumentados, devido à "responsabilidade funcional diante do Estatuto do Estrangeiro" e "a fim de evitar problemas à rede escolar estadual e aos próprios alunos".

Para resolver o problema das crianças que passaram a ter suas matrículas negadas pela rede estadual de ensino, a primeira reação da Pastoral do Migrante, após tentativas, sem sucesso, de diálogo com representantes da própria Secretaria de Educação, foi a realização de uma grande mobilização, em parceria com a CJP. Foram contatados escolas, delegacias, polícia federal, centros de defesa de direitos humanos, coordenadorias de ensino, grupos profissionais e paroquiais, consulados etc. (Bonassi, 2000, p. 176).

A falta de efetividade dessas ações iniciais e o recrudescimento da aplicação da lei que, em 1993, culminou na total impossibilidade de realizar matrículas de crianças e adolescentes sem documentos, impeliram os representantes da Pastoral do Migrante a apelar para uma estratégia própria do repertório mobilizado du-

\footnotetext{
18 "Do ponto de vista social, cultural e religioso, tem um processo também eu diria de exposição de mostrar a cultura deles. [...] Eu cheguei em São Paulo e eles faziam ainda a festa em pequenos grupos nas casas deles ou alugavam um local em que faziam a festa deles. [...] A partir dos anos 90, em 94 e 95, foi a primeira festa lá no espaço da Pastoral. [...]. Então, esse é um dado interessante, a festa sai do privado e vai para o público. Público, entre aspas, porque é o público ali da Pastoral, o espaço da Pastoral. Um público controlado, que é o espaço da Pastoral" (Silva, entrevista, 2015).

19 Promulgado em harmonia com a nova Constituição, como uma espécie de marco regulatório dos direitos humanos das crianças e adolescentes.
} 
rante o período militar diante de violações de direitos: a realização de um pedido de mediação à CJP, por meio da intervenção direta de dom Paulo Evaristo Arns. ${ }^{20}$ A partir dessa intervenção de dom Paulo, foi conseguida uma audiência com o então secretário de Educação que, diante da impossibilidade de alterar uma resolução enviada de Brasília, solicitou a elaboração de um dossiê com informações de, pelo menos, cinquenta famílias que tivessem sido impedidas de matricular seus filhos, a ser encaminhado ao ministro da Justiça (Bonassi, 2000, p. 179).

Em fevereiro de 1994, o "Dossiê Escola" foi apresentado ao Ministério Público que, diante de uma resolução estadual baseada em lei federal (o Estatuto do Estrangeiro), decidiu não a revogar até que a lei federal fosse modificada (Waldman, 2012, 2014). ${ }^{21}$

Apesar de todos os esforços, a resolução foi revogada somente em 1995, quando o advogado responsável pela causa dos imigrantes na CJP é convidado a assumir Secretaria de Justiça. O convite realizado pelo então governador Mário Covas (sucessor de Fleury), do PSDB, ocorre no bojo de um processo mais amplo tanto no nível estadual, quanto no nível federal, de adoção e internalização dos regimes internacionais de direitos humanos. Naquele momento, a Secretaria de Justiça, que deveria ser o lócus desse processo, passa a se chamar Secretaria da Justiça e Defesa da Cidadania (SJDC) e seu funcionamento passa a ser regido pelo primeiro Programa Estadual de Direitos Humanos (PEDH). ${ }^{22}$

20 De acordo com Iffly (2010, pp. 97-100), antes da criação da Comissão de Justiça e Paz que passou a fazer essa intermediação, dom Paulo Evaristo Arns "recebia, muitas vezes, das famílias dos prisioneiros ou desaparecidos, a solicitação de que escrevesse cartas intercedendo por eles".

21 Note-se que o governador à época, Luiz Antônio Fleury Filho, havia trabalhado no Ministério Público, assumindo liderança, antes de se tornar governador.

22 Esse plano foi formulado pelo Núcleo de Estudos da Violência (NEV) a partir das resoluções do I Fórum Estadual de Minorias (no qual participaram representantes de 167 entidades) e de Seminários Regionais (em que participaram representantes de 294 entidades governamentais e da sociedade civil) (Vieira, 1999, pp. 132135). 
Após a aprovação do PEDH, em 1998, foram sendo estabelecidos, progressivamente, na SJDC, as coordenações, programas e conselhos referentes à defesa dos direitos humanos no governo estadual.

Recém-empossado como Secretário de Justiça, Belisário dos Santos estabeleceu uma nova resolução, baseada na Constituição de 1988, que revogava a anterior e garantia o direito à educação a todas as crianças residentes no Estado, independentemente de sua condição jurídica.

De acordo com Waldman (2014, p. 4), na mobilização social que culminou na mudança da resolução estadual, verificou-se escassa "utilização do poder judiciário como lócus para a luta pelo reconhecimento do direito à educação e a mobilização intensa nos níveis legislativo e executivo". Acrescentaríamos, ainda, nessa caracterização das estratégias da ação coletiva, a centralidade da intervenção de dom Paulo Evaristo Arns e dos advogados da CJP.

A importância desses últimos não se deve apenas ao fato de terem participado de maneira central das ações da Pastoral do Migrante, desde o início de suas atividades, aliando-se, posteriormente, no início dos anos 1990, em suas ações diretas de intervenção para a modificação da resolução estadual, mas também por terem estabelecido uma ponte institucional, por meio de um ponto de acesso privilegiado na SJDC. ${ }^{23}$ Esse ponto de acesso (a entrada de Belisário dos Santos na SJDC) produz uma vinculação entre o governo do PSDB, a causa dos imigrantes e a causa da promoção dos direitos humanos das minorias, nas estruturas executivas do governo do estado de São Paulo.

De maneira geral, o ponto de acesso é transitório, posto que se sustenta na figura de uma pessoa com acesso privilegiado às estruturas estatais. Cessando o acesso privilegiado no momento em

${ }^{23}$ Nesse artigo, o ponto de acesso refere-se a um tipo de encaixe institucional no qual uma pessoa do movimento ou próxima a ele passa a fazer parte permanentemente ou provisoriamente de alguma estrutura político-institucional do Estado (Skocpol, 1992). 
que a pessoa deixa de ocupar o cargo referido. Entretanto, ademais de informações privilegiadas e visibilidade, o ponto de acesso pode possibilitar o estabelecimento de novos encaixes mais permanentes, a depender, entre outras coisas, do posto ocupado e do tipo de relação/vínculo entre o ocupante e os grupos e organizações civis a ele vinculados.

No caso em foco, embora Belizário não fosse membro de nenhuma organização pró-imigrantes e refugiados, mas apenas simpatizante da causa enquanto ativista do movimento em prol dos direitos humanos, o ponto de acesso aberto com a sua entrada na SJDC não se esgota em si mesmo. Três anos depois, em 1998, no primeiro $\mathrm{PEDH}$, o compromisso com os imigrantes e refugiados é expresso no item 9, "estrangeiros, refugiados e migrantes brasileiros", composto por oito subitens, incluindo-se, no 9.5, a necessidade de garantir a implementação da resolução estadual elaborada por Belizário. $^{24}$

Não obstante, note-se que as redes e conexões tecidas, desde o período da ditadura, entre alguns dos futuros fundadores do PSDB e a causa dos imigrantes e refugiados vão além do governo estadual. Já no primeiro Programa Nacional de Direitos Humanos (PNDH), de 1996, durante o governo do presidente Fernando Henrique Cardoso, do PSDB, inclui-se um capítulo intitulado "estrangeiros, refugiados e migrantes brasileiros", com objetivos de curto, médio e longo prazo. Dessa gama de objetivos, destaca-se o objetivo de curto prazo de "propor projeto de lei estabelecendo o estatuto dos refugiados", realizado, um ano depois, por meio da lei brasileira n.9474, sancionada em 1997 - reconhecida internacionalmente graças aos seus avanços em relação à proteção dos direitos humanos dos refugiados políticos (Haydu, 2011; Barreto, 2010). ${ }^{25}$

${ }^{24}$ Ver:http://www.pge.sp.gov.br/centrodeestudos/bibliotecavirtual/dh/volume\%20 i/pndhlei42209.htm.

25 Redigida a partir de uma parceria entre representantes da recém-criada Secretaria Nacional de Direitos Humanos, da Acnur (Alto Comissariado das Nações 
No governo estadual, o compromisso com os imigrantes e refugiados assumido no primeiro PEDH adquire maior institucionalidade apenas dez anos depois, no final de 2007, por meio do estabelecimento do Conselho Estadual para os Refugiados (CER), pelo então governador José Serra, do PSDB, na SJDC ${ }^{26}$ O CER foi a primeira instituição local, de caráter deliberativo, voltada para a promoção de políticas para refugiados no país. Entretanto, apesar do pioneirismo - constituindo-se no primeiro conselho estadual voltado para o tema - o CER parece não ter realizado muitas reuniões, nem ter tomado decisões relevantes em seus primeiros anos de funcionamento. ${ }^{27}$

$\mathrm{Na}$ próxima seção, exploraremos os momentos iniciais de aproximação do governo municipal da questão dos novos imigrantes, durante os anos 2000, bem como as clivagens que delinearam a formação de dois perfis no interior do domínio de agência.

\section{Primeiras aproximações entre os imigrantes, o sistema políti- co e os gestores e técnicos estatais}

Para a história do domínio de agência que estamos descrevendo, os anos 2000 são um importante divisor de águas. Da perspectiva do governo local, a implementação de instrumentos de descentralização da gestão e de incremento da participação social, com o início do governo de Marta Suplicy, do PT, dá início a abertura de novos canais de diálogo e aproximação entre os técnicos

Unidas) e da sociedade civil, essa lei define mecanismos para a implementação da Convenção das Nações Unidas sobre o Estatuto dos Refugiados, assinada nos anos 1950.

26 O CER foi estabelecido por meio do Decreto n. 52349, de 12 de novembro de 2007.

27 Não foi encontrada nenhuma ata de reunião do CER e as referências na internet ao conselho fazem menção apenas à sua criação. Nas entrevistas realizadas até o momento, as poucas pessoas que o mencionaram disseram que se tratava de uma estrutura institucional pouco relevante. 
e gestores locais e os novos imigrantes vulneráveis na cidade. Da perspectiva da sociedade civil, trata-se de um momento marcado por cisões no interior da Pastoral do Migrante, pelo advento de novas organizações em prol dos imigrantes e dos próprios imigrantes e pela multiplicação das ligações (diretas e indiretas) entre a causa dos imigrantes vulneráveis e atores de outros campos (políticos dos dois principais partidos em disputa no país, de sindicatos, de organizações patronais, de organizações de responsabilidade social etc). Tornando mais complexo e diverso o domínio de agência em formação na cidade.

Para a compreensão desses novos desdobramentos do campo de atuação dos atores sociais em defesa dos direitos dos imigrantes, apresentaremos, em seguida, dois ciclos de interação sócio-estatal que consideramos centrais nesse sentido: (i) o primeiro, em torno da garantia do direito à saúde dos novos imigrantes e, (ii) o segundo, em torno da garantia do direito à utilização do espaço urbano pelos novos imigrantes.

\subsection{Entre novos e velhos atores na garantia do direito à saúde dos imigrantes latino-americanos}

No início dos anos 2000, o governo municipal da cidade de São Paulo passou por uma série de transformações que resultaram em uma maior aproximação entre técnicos e gestores locais e os novos imigrantes na cidade. Nesse sentido, destaca-se a municipalização do atendimento básico em saúde e sua implementação por meio de coordenadorias de saúde localizadas nas recém-estabelecidas subprefeituras.

Como parte de um projeto mais amplo de aproximação das estruturas da administração municipal da população e de ampliação do atendimento aos grupos populacionais mais vulneráveis da cidade, o governo Marta Suplicy iniciou a municipalização da saúde básica. Nesse processo, destaca-se a parceria entre a Secretaria 
de Saúde e a Secretaria de Assistência Social para a implementação do Programa de Saúde da Família (PSF), nas subprefeituras com índices elevados de exclusão social. ${ }^{28}$

O modelo de atenção primária em saúde implementado por meio do PSF generaliza uma estrutura de atendimento baseada em visitas domiciliares que vinha sendo praticada em algumas unidades de saúde na cidade, como o Centro de Saúde Escola da Barra Funda, da Fundação Santa Casa (CSEBF), fundado em 1964. Conforme argumenta o médico sanitarista da Santa Casa, Nivaldo Carneiro Junior, desde os anos 1990 o trabalho de visitas domiciliares realizado pelos médicos do CSEBF, junto aos domicílios mais vulneráveis da Barra Funda, já permitia detectar mudanças socioespaciais importantes, naquela região, bem como a presença, cada vez mais numerosa, de dois grupos populacionais até então pouco presentes no cotidiano daqueles médicos: a população em situação de rua e a comunidade boliviana. Conforme recorda o sanitarista:

A minha primeira aproximação com essa questão [dos imigrantes] foi a partir de minha experiência no CSEBF, e isso se deu em torno de 1990 [...]. Nessa época, estávamos percebendo que, naquela região, havia um novo movimento urbano, de mudança: com avenidas com mais circulação de veículos, grandes empresas se estabelecendo, ou seja, uma região que estava se transformando. [...] E, na década de 1990, começava a aparecer outras populações de forma muito mais marcante: a população de rua e a comunidade boliviana (Carneiro, entrevista, 2015).

28 "E sabe qual foi a primeira ação que eles fizeram? Eles pegaram o mapa da exclusão da Aldaíza Sposati, que foi feito em 2000. E esse mapa, na verdade, foi a base e o ponto de partida para traçar na cabeça do cachorro onde é que eles iriam colocar as equipes de saúde da família" (Silveira, entrevista, 2015). Atualmente, o PSF chama-se Estratégia Saúde da Família. 
Da perspectiva do trabalho nas subprefeituras recém-inauguradas, em especial naquelas marcadas por altos índices de exclusão social, foram estabelecidas coordenadorias das secretarias como parte da rede de proteção social, possibilitando a realização de um trabalho integrado no interior daquelas novas unidades territoriais. ${ }^{29}$ Em subprefeituras como, por exemplo, as do Brás, da Mooca e da Sé, a implementação desse novo modelo administrativo, concomitante ao estabelecimento das equipes do PSF e ao início de suas visitas domiciliares, passou a trazer à tona para os técnicos e gestores locais a presença, no espaço urbano, dos novos imigrantes latino-americanos, em especial aqueles envolvidos no trabalho em oficinas de costura clandestinas.

Paralelamente a essa aproximação indireta entre os técnicos e coordenadores de algumas subprefeituras e a população imigrante, a primeira iniciativa da cúpula do executivo local voltada diretamente para a questão dos novos imigrantes e para as consequências de sua presença no espaço urbano ocorreu por meio de reuniões convocadas pelo secretário do Trabalho à época, Marcio Pochmann. Tratava-se, para o secretário, de encontrar uma solução negociada para o problema da multiplicação de oficinas de costura clandestinas com força de trabalho imigrante - responsáveis por gerar importantes distorções no mercado de trabalho local, bem como processos e acusações de dumping social no interior do setor confecções.

Para essas reuniões foram convidados representantes da área de saúde das subprefeituras com grande número de imigrantes, da Pastoral do Migrante, do governo do estado e do governo federal.

29 "No governo da Marta Suplicy houve uma grande descentralização de poder e autonomia [...] A gente tinha o mesmo desenho geográfico para a saúde, educação, assistência social, esporte - toda a rede de proteção social e mais a subprefeitura detinham o mesmo território para podermos fazer, de fato, uma gestão focada naquele território, otimizando recurso e fazendo uma política fortalecida e de fácil acesso ao cidadão comum" (Gaeta, entrevista, 2015). 
O convite aos coordenadores de saúde devia-se ao importante arsenal de informaçóes que começava a ser produzido a partir da adoção do PSF e que possibilitaria, da perspectiva do secretário do Trabalho, entre outras coisas, localizar as oficinas de costura clandestina e os imigrantes sem documentos.

No entanto, para os representantes da Pastoral do Migrante, o convite do secretário do Trabalho constituía um ensejo para uma discussão sobre a ampliação do escopo da lei para o enfretamento do trabalho escravo rural que estava prestes a ser aprovada, visando à inclusão da dimensão urbana. Paralelamente, a Pastoral do Migrante buscava formas de transformar a fiscalização e a responsabilização por trabalho escravo em meio de garantia dos direitos humanos dos imigrantes em situações de vulnerabilidade e não em justificativa para a violação de seus direitos. Porém, a impossibilidade de avançar nesse sentido no diálogo com o secretário, mais preocupado com o mercado de trabalho local e com o trabalhador nacional, acabou levando ao esvaziamento daquele espaço de debate aberto pelo executivo local.

Embora as conversas com o secretário do Trabalho não tenham resultado em nenhuma ação concreta, o encontro entre os técnicos e coordenadores de saúde das subprefeituras e os representantes da Pastoral do Migrante deu início a parcerias para a promoção do direito à saúde dos novos imigrantes, especialmente, daqueles submetidos a condiçóes insalubres de moradia e de trabalho nas oficinas de costura.

Naquele momento, os técnicos de saúde das subprefeituras com imigrantes latino-americanos (em especial, bolivianos) estavam às voltas com o primeiro importante surto de tuberculose nas oficinas de costura em que esses imigrantes moravam e trabalhavam. E um dos entraves à continuidade do tratamento dessa população com tuberculose era a exigência do número do CPF (documento inacessível aos imigrantes indocumentados) para a expedição do cartão SUS. Conforme avalia a coordenadora de 
saúde da subprefeitura da Mooca da época, a suspensão dessa exigência era uma agenda que contemplava outros grupos populacionais igualmente desprovidos de CPF, como a população em situação de rua e a indígena:

Em toda reunião na prefeitura, nós falávamos de imigrantes. Agora as pessoas também sabiam que existiam os imigrantes. E tinha um problema muito grave naquela época. Eles pediam o CPF para fazer o cartão SUS. Só que, naquela época, era muito difícil imigrantes tirarem o CPF. E, ao mesmo tempo, estavam tendo problemas com as comunidades indígenas e a população em situação de rua que também não tinham $\mathrm{CPF}$. Então, havia uma agenda forçando essa mudança e nisso um promotor federal fez um documento dizendo que era inconstitucional pedir CPF para o SUS e que a questão do imposto de renda não tinha nada a ver com a saúde. $\mathrm{E}$ aí nós conseguimos. Não foi uma luta isolada e nem articulada porque foram coisas que emergiram ao mesmo tempo (Gaeta, entrevista, 2015).

As parcerias e redes estabelecidas durante as tentativas de suspensão da exigência do CPF para a emissão do cartão SUS, acabaram fomentando o estabelecimento da Rede Somos Hermanos, protagonizada por uma articulação entre técnicos e gestores da subprefeitura da Mooca e de algumas secretarias municipais, por um lado, e representantes da Pastoral do Migrante, por outro.

A Rede Somos Hermanos foi concebida como um projeto de ação que propunha usar a saúde como porta de entrada para aproximar esses imigrantes e sensibilizar os funcionários públicos que trabalham diretamente com essa população, dando visibilidade às suas especificidades culturais e ao seu idioma. As atividades junto aos imigrantes eram realizadas em seus locais de encontro e contavam sempre com uma parte religiosa e uma parte com a equipe de saúde da subprefeitura, que levava materiais da saúde, 
em espanhol, fazia feiras da saúde, discutia filmes com os imigrantes etc. Junto aos funcionários, foram realizados cursos de espanhol e de cultura latino-americana, ministrados pela Presença América Latina (PAL) fundada em 2003. ${ }^{30}$

Tratava-se de um projeto realizado no improviso, quase sem financiamento, com a utilização de estruturas institucionais pré-existentes. Adquirindo destaque a "ação em rede", como categoria organizacional nativa, na qual os indivíduos vão agindo individualmente na construção de pontes entre esses lugares de circulação.

Então, o desenho da micropolítica foi esse. Começamos a trabalhar tanto a comunidade como os trabalhadores. E aí começamos sempre de uma forma participativa, fazendo uma reunião de avaliação e vendo como estava melhorando esse acesso. [...] A gente não precisava de dinheiro para fazer esse projeto, porque sempre tem um pouquinho sobrando em todo lugar. [...]. Era muito rápido, nós escrevíamos em 10 minutos, sentávamos lá com o Juan Plaza, ele traduzia para o espanhol, jogávamos no folder, mandávamos imprimir em parceria com o Cefor [Centro Formador de Pessoal para Saúde]. Eles rodavam um monte de folders e nós distribuíamos em todas as atividades que a gente fazia. Não tinha barreira burocrática. Como eu sempre participava de outras esferas políticas, eu sempre levava essa agenda (Gaeta, entrevista, 2015).

O projeto Rede Somos Hermanos possuía várias semelhanças com outro projeto em andamento na área da saúde, o projeto

30 A PAL foi fundada por latino-americanos já estabelecidos na cidade, como empresários, profissionais liberais etc., a partir de articulações realizadas na Assembleia Legislativa de São Paulo e na Câmara Municipal. Trata-se de uma ONG voltada para a valorização cultural, identitária e política dos imigrantes latino-americanos na cidade. 
A gente na Rua, voltado para outro grupo vulnerável e cada vez mais visível, no período, a população em situação de rua. ${ }^{31} \mathrm{Tal}$ como aquele, tratava-se de um projeto de intervenção que visava dar visibilidade a essa população e acesso aos serviços de atenção básica em saúde por meio, principalmente, da sensibilização dos técnicos diretamente envolvidos no seu atendimento.

Ambas as populações em foco nesses projetos possuíam, em comum, uma vulnerabilidade marcada pela intensa mobilidade (não possuem uma residência fixa) e extrema segregação (social, linguística, simbólica etc.) em relação à população local. Circunstância diferente daquela vivida pelos habitantes dos bairros populares em foco na implementação do PSF.

Diante dessas especificidades, no bojo do processo de municipalização da atenção básica em saúde, as organizações civis que passaram a atuar junto a essas populações começaram a reivindicar a contratação de representantes desses grupos para a composição das equipes de saúde da família.

Para o então secretário adjunto da saúde, o médico sanitarista Marco Akerman, teria sido, inclusive, devido às reivindicações da população em situação de rua que se inventou a estrutura que, posteriormente, seria apropriada para o trabalho junto aos novos imigrantes econômicos latino-americanos. Para o secretário adjunto, ademais, a população de rua era mais visível e mais numerosa para a Secretaria de Assistência Social.

É muito interessante porque o agente comunitário de saúde para ser contratado tinha de morar onde ele trabalhava e a ideia era contratar agentes comunitários de saúde moradores de rua, mas eles moram onde? Então, foi a primeira discussão interessante porque o Ministério [da Saúde] não queria contratar [...] E

31 O projeto A gente na Rua foi estabelecido a partir de uma parceria entre a Secretaria de Saúde e o Centro Municipal Nossa Senhora do Bom Parto. 
negociação vai, negociação vem, a gente abriu um concurso para contratar agentes comunitários de saúde moradores em situação de rua. Eram 10 mil nessa época, 157 vieram fazer o concurso e contratamos dez. Contratamos porque eles tinham identidade e eram pessoas em situação de rua, se eles fossem contratados e começassem a morar em casa, aí eles perderiam a identidade. Então, a ideia é o seguinte: eles eram agentes comunitários de rua e o objetivo deles era fazer a conexão entre o morador de rua e a unidade de saúde. Esse foi o jeito que o Ministério [da Saúde] encontrou e eles não estavam vinculados a nenhum território, mas estavam vinculados à unidade básica de saúde do território. Então, começou o projeto A gente na Rua. Eu acho que daí para contratar bolivianos e outros imigrantes foi um pulo. Nós já tínhamos vivido essa experiência e por que não fazer com os imigrantes também? (Akerman, entrevista, 2015).

No caso dos imigrantes latino-americanos, o projeto Rede Somos Hermanos logrou, além da contratação de agentes comunitários imigrantes - por meio de um processo seletivo que ocorreu na sede da Pastoral do Migrante ${ }^{32}$ - a possiblidade do acompanhamento dos agentes de pastoral daquela organização, nas visitas do PSF. Esses agentes divulgavam o trabalho de assistência e acolhida da Pastoral, bem como davam informações referentes à documentação e outras necessidades dos imigrantes em sua vida cotidiana na cidade.

32 "La comunidad latina está muy contenta por la contratación de los agentes comunitarios de salud. A fines del 2004, el Centro Pastoral de los Inmigrantes (CPM) y la Secretaria Municipal de São Paulo, junto con Unifesp (Universidad Federal de São Paulo) hicieron una selección de Agentes Comunitarios mediante pruebas en las cuales ochenta candidatos, disputaran seis puestos. Este logro fue posible gracias al esfuerzo de la Pastoral y de la Secretaria Municipal de Salud" (Somos Hermanos: Boletín de la Parroquia Latino-Americana, n. 8, 2004). De maneira similar ao concurso que havia sido feito para a contratação da população em situação de rua. 
Dessa forma, ao longo do ciclo de interação sócio-estatal em torno da formação da Rede Somos Hermanos, destaca-se, além da formação da própria rede, o estabelecimento de três encaixes paralelos: (i) mudança na regra para a obtenção do cartão SUS; (ii) contratação de agentes comunitários imigrantes para a composição das equipes do PSF e, (iii) abertura das equipes do PSF ao acompanhamento de voluntários da Pastoral do Migrante.

Embora reflitam, em inúmeros sentidos, a atuação de gestores e técnicos locais em parceria com os representantes da Pastoral do Migrante, esses encaixes não constituem exatamente uma invenção genuína e exclusiva desse novo ator político. Conforme vimos, ao longo da descrição acima, no caso do encaixe "i", os imigrantes eram apenas um dos grupos em disputa pelo fim da exigência do CPF, tendo uma participação coadjuvante em sua conquista. No caso dos encaixes "ii" e "iii", a adaptação do PSF aos novos excluídos da cidade (população em situação de rua e novos imigrantes de baixos recursos) ocorreu, inicialmente, devido à pressão do movimento da população em situação de rua. ${ }^{33}$ Dessa forma, os encaixes dos imigrantes seriam, nesse caso, adaptações posteriores de encaixes logrados em vista das especificidades da população em situação de rua.

Os mecanismos que permitiram a mudança institucional, expressa nos encaixes, no bojo do processo de formação da Rede Somos Hermanos, fomentaram a constituição de novos atores e redes sociais, bem como o acúmulo de novos conhecimentos e formas de atuação. Processos cujas reverberações vão além do próprio Somos Hermanos que não resistiu muito mais ao término da administração municipal de Marta Suplicy.

Para a Pastoral do Migrante, o principal articulador da Rede, o acompanhamento das equipes do PSF e o contato com

33 Esse movimento, naquele momento, havia logrado um encaixe anterior diretamente junto à Secretaria de Saúde. 
políticos locais e gestores e técnicos municipais permitiu que a organização adquirisse uma expertise que a legitimaria, nos anos posteriores, como a principal interlocutora dos atores estatais e econômicos que começaram a se engajar no combate ao trabalho escravo de imigrantes nas oficinas de costura, bem como ao tráfico internacional de pessoas no interior das estruturas estabelecidas, a partir de 2009, na SJDC, do governo estadual, nas gestões Serra e Alckmin, do PSDB.

A posição privilegiada da Pastoral resultou em acesso igualmente privilegiado a recursos provenientes de convênios (articulados pelo Núcleo de Enfrentamento ao Tráfico de Pessoas, em parceria com o Ministério Público do Trabalho e a Secretaria Regional do Trabalho) com organizações da área da responsabilidade social vinculadas às grandes empresas varejistas do setor do vestuário, que passaram a ser responsabilizadas por trabalho escravo e tráfico de pessoas.

Nesse sentido, o primeiro importante convênio celebrado pela Pastoral foi com o Instituto C\&A, em 2005. ${ }^{34}$ Momento em que foi estabelecida uma ONG no interior da estrutura institucional da missão scalabriniana, o Centro de Apoio ao Migrante (CAMI), tendo como um dos objetivos iniciais dar celeridade e apoio burocrático aos novos projetos e convênios que começaram a ser realizados pela Pastoral.

Embora a atuação na Rede Somos Hermanos tenha sido importante para que a Pastoral estabelecesse, nos anos posteriores, uma fonte de recursos privilegiada, o término da rede também marca o fim de uma atuação exclusiva daquela organização católica.

34 A parceria com o Instituto C\&A previa, por um lado, recursos para o fortalecimento institucional da organização católica e, por outro, projetos de apoio e de provisão de serviços aos imigrantes inseridos no setor de confecções. Após alguns anos, essa parceria acabou culminando na mudança da estrutura burocrática e institucional da própria Pastoral que passou a se chamar Missão Paz (Bomfim, 2010). 
Além da PAL, que se formaliza durante o momento de idealização da Rede, o próprio CAMI dá início a articulações de novas fontes de financiamento de projetos com imigrantes latino-americanos na cidade (principalmente, junto a organizações europeias e do sistema ONU, voltadas para a promoção dos direitos humanos e de cidadania dessas populações).

Divergências de caráter pessoal e político entre os fundadores do CAMI e a direção da Pastoral do Migrante acabaram precipitando uma cisão que, embora não tenha levado ao final de nenhuma das duas organizações, deu origem a uma terceira organização, em 2009, o Centro de Direitos Humanos e Cidadania do Imigrante (CDHIC). O CDHIC, fundado pelos mesmos fundadores do CAMI, herdou deste último os projetos e fontes de financiamento internacionais. Nessa nova configuração, enquanto o CAMI seguiu alinhado à Pastoral do Migrante, atuando, principalmente, como ONG responsável pela gestão de recursos de projetos de responsabilidade social, o CDHIC passou a articular um campo de oposição à atuação da Pastoral, em que a dimensão política da presença dos novos imigrantes (direito ao voto, participação social, autorrepresentação etc.) passou a contrastar com a atuação provedora e religiosa da organização católica. ${ }^{35}$

Paralelamente, desenvolvia-se, na cidade, outra disputa, em torno do comércio ambulante dos novos imigrantes, aos finais de semana, na praça Padre Bento, no bairro do Pari. Aqueles conflitos trouxeram à tona, na cena política, associações dos próprios imigrantes que, conforme veremos, foram evoluindo, ao longo do tempo, em alianças e embates junto aos dois polos do domínio de agência em formação; polos protagonizados pela Pastoral e pelo CDHIC.

35 Ressalve-se que, a despeito das caracterizações mais contrastantes, próprias aos embates políticos, a Pastoral do Migrante, atualmente Missão Paz, possui uma atuação central no debate sobre a mudança da legislação nacional e outras pautas relativas às formas de integração dessas novas populações no país. 


\subsection{Das disputas comerciais e espaciais à disputa politica}

Onze horas da manhã de domingo e eles já começam a montar suas barracas ao redor da Praça Padre Bento, no centro do Bairro do Pari, região central de São Paulo. [...] Os bolivianos, com ou sem documento legal, estão chegando para o seu sagrado encontro dominical. São seis, sete, oito mil pessoas que passam por lá até o fim da festa, lá pelas 21 horas, segundo cálculos do sargento Félix da Polícia Militar, 'Aqui é La Paz', ele diz [...]. Os bolivianos adoram cerveja, não por acaso, a praça foi rodeada de bares para a imensa comunidade boliviana que vive em São Paulo e lá se apinha não só para matar a saudade de sua terra com seus conterrâneos, como para procurar emprego, trocar informações sobre documentos, arranjar um lugar para morar, receber orientação dos migrantes veteranos, ganhar algum dinheiro na barraca [...]. A feira ainda não regularizada pela prefeitura funciona ao redor da Praça [...]." (Folha de S. Paulo, Caderno Cotidiano, 15 jul. 2001. "SP vira embaixada da Bolívia”, por Célia Chaim).

Eu falei 'Olha, nós não precisamos da Igreja, nós não precisamos de intermediários, de alguém que fale por nós. Nós podemos falar de nós mesmos. Não precisamos mais que alguém queira nos liderar, achando que estão nos representando'. Em qualquer instância, esfera da política brasileira, eles aparecem como representantes da comunidade imigrantes, eu nunca nomeei eles. Nunca tive nenhum contato com eles (Vasquez, entrevista, 2015). 
O bairro do Pari caracteriza-se por ser um importante local de acolhimento de imigrantes de diversas nacionalidades que se dirigiram para a cidade desde fins do século XIX. Nesse bairro, a praça Padre Bento desempenha a função de local de sociabilidade dessas comunidades de imigrantes aos finais de semana, produzindo um ambiente marcado pela diversidade de línguas e de produtos e serviços comercializados.

Conforme podemos entrever no primeiro dos trechos citados acima, a despeito do cosmopolitismo inerente à história do bairro, durante os anos 2000 essa praça e esse bairro foram palco de disputas territoriais entre os moradores locais das antigas comunidades de imigrantes, os comerciantes nacionais e os novos imigrantes latino-americanos (especialmente bolivianos). Para os antigos moradores, essas novas populações passam a ser identificadas com bebida em excesso, apinhamento, ilegalidade e subcontratação. Essas tensões resultaram em um abaixo-assinado, realizado pelo Conselho Comunitário de Segurança, que recebeu a adesão de 2.500 pessoas, determinando a retirada dos comerciantes bolivianos da praça, no final de 2001.

$\mathrm{Na}$ prática, essas disputas desencadearam a formação de novas organizações de imigrantes e de novas articulações com as estruturas participativas do município (como, por exemplo, os conselhos) e com representantes do sistema político local, em meio a embates, muitas vezes violentos, no cenário urbano, como o narrado por uma das lideranças bolivianas, emergentes neste contexto.

Na Praça Padre Bento. Um dia, ele [o vereador Adilson Amadeu] chegou pra mim e falou: 'Juan, você não pode ficar mais aqui, você tem que tirar tuas vendedoras daqui'. Eu falei: 'tudo bem, eu vou ter que buscar outro lugar onde vou poder levar.' E ele: 'Não, você tira este domingo. Não quero mais'. Entonce, ele era uma pessoa civil, era um deputado, um 
vereador, ele tinha poder e arranjamos uma briga campal, na Igreja mesmo. [...] porque eu não era uma persona documentada. [...]. Tinha uma reunião de conselho, até hoje eu assisto às reuniões de conselho, tinha uns 3 bolivianos, mais ou menos, e a turma dos brasileiros, instituiciones, era a ARPA, ${ }^{36}$ uma instituição também do Brás, Pari, Canindé e eu encarei ele né. E ele me deu um tapa na cara, o Adilson. E aí eu parti pra cima também, eu não consegui dar nada nele porque tinha um brasileiro lá que nos separou, mas a briga entre bolivianos e brasileiros foi tremenda (Merluvia, entrevista, 2006).

Diante do aumento da presença de imigrantes latino-americanos na cena política local e de suas articulações com vereadores favoráveis às suas demandas, por um lado, e com a rede de contatos da Pastoral do Migrante, por outro, foi lograda a transferência dos comerciantes bolivianos para uma praça no mesmo bairro, no Pari, que passou a funcionar aos domingos, a praça Kantuta. ${ }^{37}$ Além da feira gastronômica, a praça se tornou um espaço multisserviços voltado, especialmente, para os costureiros latino-americanos e um palco de manifestações culturais e comemorações religiosas da comunidade latina na cidade.

Embora tenha sido conquistada em 2002, a regulamentação da praça ocorreu apenas em 2004, tendo permanecido sem infraestrutura básica em seus primeiros anos de funcionamento (Silva, 2005, p. 40). Esse encaixe inicial e a necessidade de consolidá-lo acabaram levando à formação da Associação Kantuta que passou a reivindicar, em parceria com a Pastoral, junto ao poder público, a regulamentação da praça e uma infraestrutura básica para a realização das atividades comerciais, culturais e religiosas.

36 Associação Pela Revitalização do Bairro do Pari.

37 Nome de uma flor que cresce no altiplano andino e que possui as cores da bandeira da Bolívia: verde, amarelo e vermelho. 
As íntimas conexões entre o comércio de alimentos e serviços para a comunidade latina (em especial, a boliviana) e a atividade da costura podem ser vislumbradas na fundação de outra associação, em 2004, pelos mesmos líderes/fundadores da Associação Kantuta, voltada justamente para a promoção dos interesses dos donos de oficinas de costura bolivianos, a Associação Social e Cultural Bolívia Brasil (Bolbra). ${ }^{38}$

De maneira concomitante, desenvolvia-se um silencioso e significativo processo de ocupação residencial e comercial de bolivianos e de suas oficinas de costura na rua Coimbra, no mesmo bairro, e em suas imediações. Aos finais de semana, essa rua passou a abrigar uma feira ilegal voltada para os costureiros e oficinistas latino-americanos. Apesar de não estabelecerem uma organização formal, os vendedores foram se multiplicando, ao longo dos anos, chegando a somar 350 feirantes imigrantes.

Embora, inicialmente, os feirantes se submetessem a algumas regras e taxas estabelecidas por uma organização informal dos comerciantes fixos da rua (a princípio, diretamente vinculada à Bolbra e, por conseguinte, à Pastoral), com o tempo, os feirantes começaram a se opor aos comerciantes. A principal discordância entre os comerciantes e os feirantes deve-se à tentativa dos primeiros de diminuir o comércio ambulante na rua Coimbra e, em especial, em frente aos seus próprios estabelecimentos.

Em meio aos conflitos entre os comerciantes e os feirantes, estabelece-se, na rua Coimbra, um novo empresário boliviano, ex-oficinista, com o primeiro empreendimento comercial voltado para o abastecimento das oficinas de costura bolivianas e para a promoção de suas atividades (incluindo-se o oferecimento de serviços de

38 De acordo com um de seus fundadores, Marcos Canaviri, a Bolbra "nasceu devido a essa necessidade de podermos liderar os nossos patrícios no setor de confecção e poder conversar com os coreanos [...]" (http://textileindustry.ning.com/forum/ topics/a-bol-via-aqui) 
regularização migratória aos donos e costureiros das oficinas). ${ }^{39}$ Com o aumento de sua influência e popularidade, graças ao êxito nos negócios, o empresário decide se estabelecer na cena política a partir de uma articulação com os feirantes da rua Coimbra. Essa articulação política originou, em 2008, a Associação Coimbra, que passou a se opor aos comerciantes fixos da rua (associados à Pastoral e à Bolbra).

Diante desse novo diagrama de relações, inicia-se uma aproximação entre a Associação Coimbra e o CDHIC. Parceria que adquire maior relevância política durante as eleições de 2012, para prefeito e vereadores, da cidade de São Paulo. O empresário boliviano, presidente da Associação Coimbra, doou recursos financeiros para a campanha à vereador do fundador do CDHIC, do PT, em troca de apoio político para a conquista da legalização da feira de comerciantes ambulantes da rua Coimbra.

Adicionalmente, foi negociado o apoio daqueles imigrantes ao candidato à prefeitura pelo PT, Fernando Haddad. Nessas negociações, além da legalização da feira da Coimbra, foi proposto: (i) o estabelecimento de uma estrutura (coordenação) de apoio e promoção de direitos aos novos imigrantes, no interior da Secretaria de Direitos Humanos e, (ii) cadeiras extraordinárias para representantes de imigrantes para os conselhos participativos das subprefeituras caracterizadas pela alta incidência de populações imigrantes.

39 Em suas próprias palavras: "Na loja, nós criamos um conceito diferente, não era uma loja típica. Em qualquer loja que você vai, você compra o produto e a relação acaba aí. Eu percebi que meus clientes eram empreendedores, donos de oficina. Não eram os costureiros. E, no bate papo, percebi que os oficinistas passavam muitas dificuldades, principalmente, em relação à documentação. E nós pensamos em uma firma em que o nosso objetivo não é vender fios e linhas, nosso lema é apoiar o desenvolvimento da sua oficina. Por isso, falo em apoio e capacitação, pois é uma estratégia de negócio: se os meus clientes crescerem mais, eu ganho. Esse foi o raciocínio para ajudá-los" (Trecho de entrevista com Vasquez, presidente da Associação Coimbra). 
Foi todo um trabalho político da Associação. Eu levei eles para reuniões, marchas, um trabalho político, foi assim que nós aprendemos a trabalhar com o lado político [...] quando fazemos reunião, o boliviano é um pouco difícil de ir, muito pouco boliviano novo, são os mesmos de sempre, você já percebeu, né? Mas nós conseguimos levar novas pessoas. Aqui, eu tenho, na Associação, uma liderança muito forte, se falar "temos que ir lá", a gente vai. Tínhamos uma reunião com o Haddad na época da campanha ainda, falei "pessoal, temos que encher o salão onde vai lá o Haddad, não podemos chegar com o salão vazio, que impressão vai ter? (Vasquez, entrevista, 2015).

E esses imigrantes conseguiram, de fato, encher o salão e conquistaram o compromisso do candidato, formalizado em seu Plano de Metas, com as três principais reivindicações. Compromisso que foi implementado nos primeiros anos de sua gestão, tal como vimos na abertura deste artigo. Embora o processo político tenha sido liderado por uma parceria entre a Associação Coimbra e o CDHIC, a proposta de uma estrutura institucional permanente para os imigrantes e de alguma forma de participação nos conselhos locais são reivindicações que extrapolam o âmbito de atuação daquelas organizações, estando presentes, de maneiras diversas, nos discursos dos outros atores sociais que foram, ao longo do tempo, conformando o domínio de agência em foco - como, por exemplo, a própria Pastoral.

De todo modo, no momento em que a direção da CPMig é atribuída ao fundador e principal liderança do CDHIC - frustrando a expectativa da Pastoral de assumir a direção daquela estrutura institucional - começa a se delinear, com mais clareza, um campo de oposições que repõe, em outros níveis da hierarquia política local, uma cisão iniciada no interior da própria Pastoral. $\mathrm{Na}$ próxima seção, propomos uma análise inicial das dimensões, horizontal e vertical, dos dois perfis que passam a compor esse domínio de agência dos novos imigrantes na cidade. 


\section{Entre assistência e política no novo domínio de agência na cidade}

A partir dos processos de interação sócio-estatal considerados nas seções anteriores, foi possível constatar que os encaixes logrados em torno dos interesses dos novos imigrantes vulneráveis, na cidade de São Paulo, caracterizam-se pela fluidez e pela dispersão por entre setores e estruturas burocráticas diversas, em torno da gestão dos "problemas sociais" advindos da presença das novas populações. Tais como problemas referentes a regularização migratória, saúde pública, vulnerabilidade social, trabalho escravo, tráfico de pessoas e regulamentação de atividades econômicas, culturais e/ou políticas no espaço urbano.

No interior daqueles encaixes, os novos imigrantes adquirem nomeações diversas, podendo, inclusive, fazer parte de mais de uma das categorias - tais como "refugiado político", "escravo", "vítima de tráfico de pessoas"; "latino-americano", "refugiado humanitário". Essas nomeações correspondem a legislações ou mesmo estruturas institucionais específicas. ${ }^{40}$

A despeito das fragmentações dos encaixes e das nomeações dos sujeitos aos quais se referem, quando partimos da perspectiva dos atores sociais diretamente envolvidos em sua institucionalização (as organizações e associações em prol dos imigrantes), ao longo do tempo, nos deparamos com um campo de disputa que, embora seja complexo, possui limites e especificidades passíveis de uma abordagem analítica.

Em torno de toda a variedade de encaixes institucionais logrados é possível detectar uma gama de atores permanentes que circulam por entre esses encaixes e outras estruturas sociais que foram se constituindo ao longo dos diversos ciclos de interação sócio-estatal.

40 Os refugiados, por exemplo, são regidos pelo Estatuto do Refugiado, os latinoamericanos pelo Acordo de Residência do Mercosul e assim por diante. 
No período democrático, conforme buscamos argumentar, novos atores sociais foram estabelecidos e os antigos atores evoluíram em suas posições à medida que foram se institucionalizando - transformando estratégias e formas de atuação, bem como estabelecendo articulações e antagonismos entre si e com os demais atores da cena política-institucional.

A análise desses desdobramentos nos permitiu a identificação de dois perfis no interior do novo domínio de agência em formação na cidade, cujos delineamentos gerais podem ser vislumbrados na fala abaixo:

Entre parênteses, vou ter que contar umas coisas aí. Na comunidade, existe uma luta de grupos de interesse. Por um lado, está a Igreja católica, liderada pela Pastoral e pelo CAMI, aquele grupo que sempre, historicamente, falaram em nome dos bolivianos [...]. Esse é um grupo, eles sempre dominaram a comunidade. Eles se acham representantes da comunidade. Eles acham que podem decidir tudo pela comunidade, é a velha guarda. [...] E eles tem que ter um lugar onde, uma instituição, um grupo de pessoas para influenciar diretamente e eles pegaram a Kantuta. A Feira Kantuta é um centro de ação deles. Enquanto o Paulo Illes [fundador do CDHIC] apoiou a mim na Coimbra. Então, Coimbra e Kantuta viraram briga de duas lideranças na comunidade (Vasquez, entrevista, 2015).

A assertiva acima, proferida por um dos protagonistas de uma cisão interna à comunidade boliviana, revela, de maneira bastante direta - mesmo que enviesada pelos interesses daquele que a profere - o jogo de oposiçóes que começa a se delinear entre a "velha" e a "nova" guarda e que articula, em torno dos dois perfis, atores e estruturas institucionais pertencentes aos vários níveis da hierarquia política local. 
Nesse sentido, no âmbito das disputas comerciais e territoriais urbanas entre os próprios imigrantes (no caso descrito, da comunidade boliviana), em um dos níveis mais baixos de hierarquia política dos atores, a velha guarda se refere à Associação Kantuta, em parceria com a Bolbra e os comerciantes permanentes da rua Coimbra; enquanto a nova guarda se refere à Associação Coimbra, em torno da qual começam a se organizar os imigrantes que realizam o comércio ambulante naquela rua. ${ }^{41}$

Esse jogo de oposições entre organizações dos próprios imigrantes no nível das disputas comerciais e territoriais urbanas é transposto, em outros termos, em um nível intermediário da hierarquia política dos atores. Nível no qual a velha guarda é representada pela Pastoral do Migrante em parceria com o CAMI que se opõe à nova guarda representada pelo CDHIC. ${ }^{42}$

Consideramos que são esses os principais atores responsáveis pela constituição do domínio de agência em foco (Pastoral e CAMI versus $\mathrm{CDHIC)}$. No nível intermediário da hierarquia política dos atores sociais, as disputas no interior da sociedade civil relacionam-se mais diretamente às estruturas político-institucionais do estado (nos níveis municipal e estadual). E os atores sociais envolvidos são os principais responsáveis pela realização das articulações entre os níveis inferiores e superiores da hierarquia política. Nesse sentido, em relação às suas articulações com os níveis inferiores, teríamos, por um lado, a Pastoral e o Cami articulados à Bolbra e à Associação Kantuta, bem como a outras pequenas associações, em sua maioria, de caráter assistencial não apenas de bolivianos, mas de outros grupos que compõem as migrações mais

41 Nas descrições foram indicadas apenas as organizações e/ou associações principais, não excluindo-se a existência de outras estruturas menores que, de maneiras diversas, passaram a apoiar a ação das primeiras.

42 Nesse nível também foram consideradas apenas as organizações principais não se excetuando a existência de outras organizações e/ou associações que também lograram o estabelecimento de encaixes no novo domínio de agência. 
recentes para a cidade (com destaque para as associações haitianas). E, por outro lado, o CDHIC articulado à Associação Coimbra e a outras pequenas associações de imigrantes de outros grupos (com destaque para as associações de sírios e senegaleses), muitas vezes vinculados a movimentos sociais dos países de origem, bem como a organizações de outros atores dos movimentos sociais mais tradicionais na cidade.

Em relação ao nível mais elevado da hierarquia política observada, o político partidário, encontramos que a luta contra a ditadura no país, em especial, seus desdobramentos no âmbito da CJP, em São Paulo, que representava uma articulação entre ativistas de direitos humanos e os segmentos progressistas da Igreja católica, conformam o contexto comum de aproximação entre organizações civis em prol dos imigrantes e lideranças políticas que, no regime democrático, vão fundar os dois principais partidos de oposição do país: o PT e o PSDB. Nesse sentido, a própria Pastoral do Migrante, a mais antiga e mais estruturada organização civil do domínio, foi fomentada por dom Paulo Evaristo Arns, em diálogo com os representantes da missão scalabriniana, durante a ditadura, em vista da parceria da CJP com a Acnur para a provisão de acolhimento aos refugiados latino-americanos.

Durante os anos 2000, antigas lideranças da Pastoral constituíram duas novas organizações que passaram a se opor no interior do domínio de agência, o CDHIC e o CAMI (este último seguindo em parceria com a Pastoral). Oposição transposta, em outros termos, para o nível superior da hierarquia política observada a partir das articulações entre, por um lado, a Pastoral e o Cami a políticos e técnicos do PSDB e, por outro lado, o CDHIC a políticos e técnicos do PT. Circunstâncias que se refletem nas configurações horizontais de encaixes dos dois perfis configuracionais: os encaixes associados à Pastoral e ao CAMI passaram a se concentrar, em grande medida, nas estruturas executivas do governo estadual (logrados durante gestões do PSDB) e os encaixes associa- 
dos ao CDHIC, nas estruturas executivas do governo municipal (logrados durante gestões do PT).

Essas articulações com os níveis superiores de hierarquia política dos atores também se refletem nas fontes de financiamento das três organizações protagonistas do domínio de agência. Nesse sentido, a Pastoral e o Cami se engajaram, no período observado, em projetos e convênios com organizações de responsabilidade social, direta ou indiretamente vinculadas a empresas do setor de confecções. Trata-se do principal setor responsabilizado por trabalho escravo imigrante, muitas vezes associado ao crime de tráfico de pessoas, na cidade de São Paulo. Os encaixes logrados pelas duas organizações, nas estruturas executivas dos governos estaduais liderados pelo PSDB também dizem respeito a essa temática e, de diversas maneiras, acabam reconhecendo àquelas organizações uma certa expertise na área que possibilita a obtenção daquele tipo de financiamento.

Por sua vez, o CDHIC passou a se engajar em projetos e convênios com ONGs europeias e Organizações Internacionais voltadas para a defesa dos direitos humanos e para a promoção de práticas de cidadania e de participação social. Essas fontes de financiamento também passaram a ser mobilizadas pelos representantes de outros movimentos sociais urbanos, mais tradicionais e igualmente próximos ao $\mathrm{PT}$, durante o período democrático contemporâneo.

Finalmente, os perfis constitutivos do domínio de agência analisado, emergentes das articulações verticais e horizontais, tecidas pelas organizações civis nas interações sócio-estatais consideradas, conformam ideais diferenciados de participação política e integração dos novos imigrantes: no caso do perfil nucleado pela Pastoral e pelo Cami, adquirem destaque pautas relacionadas ao combate ao trabalho escravo e ao tráfico de pessoas, bem como uma atuação voltada para o acolhimento dos imigrantes e provisão de serviços por meio de convênios com as organizações de responsabilidade social. E, no caso do perfil nucleado pelo CDHIC, 
adquirem destaque pautas relacionadas à participação e representação política dos imigrantes e acesso a direitos, bem como a realização de atividades de formação e de reivindicação política.

Atualmente, o cenário político partidário e institucional brasileiro passa por importantes mudanças tanto nacionalmente, quanto regionalmente, em especial após o impedimento da então presidente Dilma Rousseff, do PT, em 2016. E essas mudanças no nível superior da hierarquia política, embora ainda bastante imprevisíveis quanto ao seu alcance e consequências, certamente terão impactos nas dinâmicas e correlações de força das organizações civis que compõem o domínio de agência analisado.

A partir da perspectiva analítica desenvolvida neste capítulo, podemos entrever, por exemplo, rearranjos nas fontes de financiamento das organizações, nos formatos dos encaixes horizontais, nos temas e abordagens propostas e nas próprias articulaçóes das organizações do domínio tanto em relação aos níveis inferiores quanto aos níveis superiores da hierarquia política dos atores sociais - com a morte de algumas das organizações, emergência de outras e mudanças nas parcerias e nos arranjos com os atores do sistema político-partidário regional. Impactos que se referem às determinantes institucionais da ação coletiva e que, no contexto atual, podem significar tanto mudanças mais radicais em relação aos padrões que vêm se constituindo desde os anos 1980, com o estabelecimento de um novo perfil configuracional no interior do domínio de agência, quanto apenas pequenos rearranjos no interior das trajetórias dos perfis analisados.

\section{REFERÊNCIAS}

ADORNO, Sérgio. História e desventura: o $3^{\circ}$ Programa Nacional de Direitos Humanos. Novos Estudos Cebrap, 2010, n. 86, pp. 5-20.

ASSIS, Gláucia de Oliveira; SASAKI, Elisa Massae. Novos imigrantes do e para o Brasil: um balanço da produção bibliográfica. In: Castro, Mary Garcia (Ed.). 
Migraçôes internacionais: contribuições para politicas. Brasília: CNPD, 2001, pp. 615-639.

AZEVEDO, Flávio Antônio Gomes. A presença de trabalho forçado na cidade de São Paulo: Brasil/Bolivia. Dissertação (Mestrado em Economia) - Universidade de São Paulo, São Paulo, 2005.

BAENINGER, Rosana. São Paulo e suas migrações no final do século 20. São Paulo em Perspectiva, 2005, v. 3, n. 19, pp. 84-93.

BUECHLER, Simone. Sweating it in the Brazilian Garment Industry: Korean and Bolivian Immigrants and Global Economic Forces in São Paulo. Latin American Perspectives, 2004, v. 31, n. 3, pp. 99-119.

CARLOS, Euzeneia. Movimentos sociais e instituições participativas: efeitos organizacionais, relacionais e discursivos. Tese (Doutorado em Ciência Política) - Universidade de São Paulo, São Paulo, 2012.

CÔRTES, Thiago Rangel. Os imigrantes da costura em São Paulo: retalhos de trabalho, cidade e Estado. Dissertação (Mestrado em Sociologia) - Universidade de São Paulo, São Paulo, 2013.

DOWBOR, Monika. A arte da institucionalização: estratégias de mobilização dos sanitaristas (1974-2006). Tese (Doutorado em Ciência Política) Universidade de São Paulo, São Paulo, 2012. Disponível em: <http://dx.doi. org/10.11606/T.8.2012.tde-06032013-111003>.

FREIRE, Carlos. Trabalho informal e redes de subcontratação: dinâmicas urbanas da indústria de confeç̧ões em São Paulo. Dissertação (Mestrado em Sociologia) Universidade de São Paulo, São Paulo, 2008.

FREITAS, Patrícia Tavares. Imigração boliviana para São Paulo e setor de confecção: em busca de um paradigma analítico alternativo. Informe Gepec, 2011, v.15, pp. 222-240. Disponível em: <http://saber.unioeste.br/index.php/ gepec/article/view/6280/4790>.

FREITAS, Patrícia Tavares. Entreprise ethnique, territorialités et filière migratoire: les migrants boliviens dans l'industrie du vêtement à São Paulo. e-Migrinter, 2012, v. 8, pp. 109-111. Disponível em: <https://journals. openedition.org/e-migrinter/611>.

FREITAS, Patrícia Tavares. Trajetórias laborais/residenciais dos locais de origem e projeto migratório: a migração boliviana para o setor de confecção 
da cidade de São Paulo. In: Baeninger, Rosana; Dedecca, Claudio Salvadori (Org.). Processos migratórios no estado de São Paulo: estudos temáticos. Campinas: Núcleo de Estudos de População (NEPO)/Unicamp, 2013a, pp. 523-550. Disponível em: <http://www.nepo.unicamp.br/publicacoes/livros/colecaosp/ VOLUME_10.pdf $>$.

FREITAS, Patrícia Tavares. Bolivianos(as) por entre oficinas de costura na cidade de São Paulo: novos aspectos da dinâmica migratória no século 21 . In: Baeninger, Rosana (Ed.). Migração internacional. Campinas: NEPO/ Unicamp, 2013b, pp. 77-102. Disponível em: <http://www.nepo.unicamp.br/ publicacoes/livros/colecaosp/VOLUME_09.pdf > .

FREITAS, Patrícia Tavares. Família e inserção laboral de jovens migrantes na indústria de confecção. Revista Interdisciplinar de Mobilidade Humana (Remhu), 2014, n. 42, pp. 231-246.

FREITAS, Patrícia Tavares. Migrações internacionais e cidadania local: um estudo sobre a formação de um novo domínio de agência na cidade de São Paulo. In: Baeninger, Rosana et al. (Ed.). Imigração haitiana no Brasil. Jundiaí: Paco Editorial, 2016, pp. 427-450.

GURZA LAVALLE, Adrian; HOUTZAGER, Peter; CASTELLO, Graziela. A construção política das sociedades civis. In: Gurza Lavalle, Adrian (Ed.). $O$ horizonte da politica: questôes emergentes e agendas de pesquisa. São Paulo: EdUnesp/Cebrap/CEM, 2012, pp. 185-259.

GURZA LAVALLE, Adrian; INSUNZA, Ernesto. Precisiones conceptuales para el debate contemporáneo sobre la innovación democrática: participación, controles sociales y representación. In: Gurza Lavalle, Adrian; Insunza, Ernesto (Ed.). La innovación democrática en América Latina: tramas y nudos de la representación, la participación y el control social. Mexico: Ciesas, 2010, pp. 1780 .

GURZA LAVALLE, Adrian; SZWAKO, José. Sociedade civil, Estado e autonomia. Opinião Pública, 2015, v. 21, n. 1, pp. 157-187.

HOUTZAGER, Peter. From polycentrism to the polity. In: Houtzager, Peter; Moore, Mick (Ed.), Changing Paths: International Development and the New Politics of Inclusion. Ann Arbor, MI: University of Michigan Press, 2005, pp. $1-31$.

INSUNZA, Ernesto; GURZA LAVALLE, Adrian. Develando cauces recurrentes: los controles democráticos no electorales como prácticas de 
resignificación en la construcción democrática. In: Insunza, Ernesto (Ed.). Controles democráticos no electorales y régimen de rendición de cuentas en búsqueda de respuestas comparativas: México, Colombia, Brasil, China y Sudáfrica. México: Ciesas, 2013, pp. 9-62.

PATARRA, Neide Lópes. Migrações internacionais do e para o Brasil contemporâneo: volumes, fluxos, significados e políticas. São Paulo em Perspectiva, 2005, v. 19, n. 3, pp 23-33.

PISCITELLI, Adriana. Entre as 'máfias' e a 'ajuda': a construção do conhecimento sobre tráfico de pessoas. Cadernos Pagu, 2008, n. 31, pp. 29-63.

PISCITELLI, Adriana; VASCONCELOS, Marcia. Apresentação. Cadernos Pagu, 2008, n. 31, pp. 9-28. (Dossiê Gênero no Tráfico de Pessoas)

SKOCPOL, Theda. Introduction: Understanding the Origins of Modern Social Provision in the United States. In: Skocpol, Theda. Protecting Soldiers and Mothers: The Political Origins of Social Policy in the United States. Cambridge, MA: Harvard University Press, 1992, pp. 1-62.

STEFFENS, Isadora; Martins, Jameson. 'Falta um Jorge': a saúde na política municipal para migrantes de São Paulo. Lua Nova, 2016, n. 98, pp. 275-299. Disponível em: <http://dx.doi.org/10.1590/0102-6445275-299/98>.

\section{DOCUMENTOS E FONTES}

BARRETO, Luiz Paulo Telles Ferreira (Ed.). Refúgio no Brasil: a proteção brasileira aos refugiados e seu impacto nas Américas. Brasília: Acnur/Ministério da Justiça, 2010.

BIGNAMI, Renato. Trabalho escravo contemporâneo: o sweating system no contexto brasileiro como expressão do trabalho forçado urbano. 2011. Disponível em: <http://reporterbrasil.org.br/2011/12/sweating-system-trabalho-escravocontemporaneo-no-setor-textil/>. Acesso em: 29 abr. 2018.

BOMFIM, Leila Aparecida. Sistematização da Memória da Pastoral dos Imigrantes da Missão Scalabriniana Nossa Senhora da Paz. Documento do Centro de Estudos Migratórios, Missão Paz, São Paulo, 2010. 
BONASSI, Margherita. Canta, América sem fronteiras: imigrantes latinoamericanos no Brasil. São Paulo: Loyola, 2000.

DORNELAS, Sidnei Marco. Para sair do confinamento: a experiência das visitas às oficinas de costura de imigrantes bolivianos no quadro do Projeto Somos Hermanos. Travessia: Revista do Migrante, 2009, n. 63, pp. 20-25.

GONÇALVES, Alfredo, padre; CUTTI, Dirceu. Seminário João XXIII e Centro de Estudos Migratórios: memória de um passado recente. Travessia: Revista do Migrante, 2005, n. 52, pp. 17-24.

IFFLY, Catherine. Transformar a metrópole: Igreja católica, territórios e mobilizações sociais em São Paulo, 1970-2000. São Paulo: EdUnesp, 2010.

SILVA, Sidney. 'A praça é nossa': faces do preconceito em um bairro paulistano. Travessia: Revista do Migrante, 2005, n. 51, pp.39-44.

WALDMAN, Tatiana Chang. $O$ acesso à educação escolar de imigrantes em São Paulo: a trajetória de um direito. Dissertação (Mestrado em Direito) Universidade de São Paulo, São Paulo, 2012.

WALDMAN, Tatiana Chang. Migrações internacionais, movimentos sociais e acesso à justiça no Estado de São Paulo: a luta pela efetivação do direito à educação escolar. In: Encontro da Associação Nacional de Direitos Humanos, Pesquisa e Pós-Graduação (Andhep), 8., 2014, São Paulo.

\section{LISTA DE ENTREVISTADAS E ENTREVISTADOS}

AKERMAN, Marco. Marco Akerman, sanitarista: entrevista [19 maio 2015]. Entrevistadora: Patrícia Tavares de Freitas. Entrevista concedida para pesquisa de pós-doutorado da entrevistadora.

CARNEIRO, Nivaldo. Nivaldo Carneiro, sanitarista [24 març.2015]. Entrevistadora: Patrícia Tavares de Freitas. Entrevista concedida para pesquisa de pós-doutorado da entrevistadora.

GAETA, Rosana. Rosana Gaeta, técnica de saúde [12 março 2015]. Entrevistadora: Patrícia Tavares de Freitas. Entrevista concedida para pesquisa de pós-doutorado da entrevistadora. 
MERLUVIA, Jorge. Jorge Merluvia, fundador da Associação Kantuta [18 abri. 2006]. Entrevistadores: Patrícia Tavares de Freitas, Carlos Freire e Robert Cabannes. Entrevista concedida para o projeto "Mobilidades ocupacionais e reconfigurações societárias na cidade de São Paulo", coordenado por Vera Telles.

SILVA, Sidney. Sidney Silva, ex-padre da Pastoral do Migrante [15 março 2015]. Entrevistadora: Patrícia Tavares de Freitas. Entrevista concedida para pesquisa de pós-doutorado da entrevistadora.

SILVEIRA, Cassio. Cassio da Silveira, sanitarista [5 fev. 2015]. Entrevistadora: Patrícia Tavares de Freitas. Entrevista concedida para pesquisa de pós-doutorado da entrevistadora.

VASQUEZ, Luiz. Luiz Vasquez, presidente da Associação dos Feirantes da rua Coimbra [18 fev. 2015]. Entrevistadora: Patrícia Tavares de Freitas. Entrevista concedida para pesquisa de pós-doutorado da entrevistadora. 



\author{
Capítulo 3 \\ A CONSTRUÇÃO DE ENCAIXES \\ INSTITUCIONAIS E DOMÍNIO DE AGÊNCIA \\ NO MOVIMENTO POPULAR URBANO: \\ MECANISMOS E CONFIGURAÇÕES
}

Euzeneia Carlos

\title{
Introdução
}

No contexto de transformações nas relações entre o Estado e a sociedade civil no Brasil pós-transição, a explicação dos processos de institucionalização requer a consideração do caráter mutuamente constituído das inter-relações entre essas esferas. Ao contrário das perspectivas estritamente centradas no Estado ou na sociedade civil como esferas dicotômicas e autônomas, o enfoque dinâmico dessas dimensões como campos em interação, cujas fronteiras são fluidas e imprecisas, permite apreender suas configurações como produto de um processo interativo e contingente de mútua constituição (Skocpol, 1992).

Neste capítulo, o pressuposto de mútua constituição entre Estado e sociedade civil e a sua articulação às teorias dos movimentos sociais realça os atores institucionais e os sociais como politicamente relevantes e mutuamente imbricados na conformação da ação coletiva e das interações socioestatais. Essa vinculação analítica é fundamental à compreensão das interconectividades entre atores coletivos e instituições, especialmente no contexto de institucionalização dos canais de mediação pós-Constituição 
Federal de 1988. Ao enfocar a relação entre atores estatais e societários, esta abordagem ascendeu o papel crítico que o Estado e as instituições políticas desempenham na configuração da sociedade civil, possibilitando oportunidades para grupos ou movimentos arquitetar o "encaixe institucional" (engineering fit), ao mesmo tempo em que as restringe a outros, enquanto pontos de acesso às instituições e de influência política no processo de decisão (Skocpol, 1992, p. 54). Contudo, o reconhecimento amplo do postulado de mútua constituição do Estado e sociedade civil exige que a ênfase na centralidade da configuração institucional dos governos e dos sistemas de partidos, como condicionante crucial da ação de atores políticos e sociais, seja complementada pela noção de que "o condicionamento, além de recíproco, é de índole iterativa e molda tanto as capacidades dos atores societários quanto as das instituições políticas" (Gurza Lavalle, Houtzager e Castello, 2011; Gurza Lavalle, Carlos, Dowbor e Szwako, 2017 e neste livro). Conferindo o mesmo status ontológico às duas dimensões, não somente o Estado condiciona as capacidades dos atores societários, mas igualmente os últimos são construtores do primeiro.

Os encaixes $(f i t)$ conferem aos atores sociais acesso mais permanente às instituições, ampliando sua capacidade de influência (Carlos, Dowbor e Albuquerque, 2017). Conforme argumentado no capítulo de abertura deste livro, os encaixes são definidos relacionalmente como processos intermediários de solidificação institucional derivados de interações socioestatais, que atribuem alguma agência com certa duração aos atores sociais envolvidos na institucionalização de demandas e ações. Nesse processo de institucionalização de médio alcance, as modalidades de encaixes institucionais podem constituir "domínios de agência", quando a legitimidade e agência dos atores sociais são reconhecidos pelo Estado em um âmbito específico de política. Enquanto produto de processos históricos de conflito, aprendizagem e cooperação, os domínios de agência possuem perfis configuracionais, sendo compostos por encaixes, ca- 
pacidades de ação e de organização e por capacidades estatais (Gurza Lavalle, Carlos, Dowbor e Szwako, 2017 e neste livro).

Essa abordagem de domínios de agência, que descansa sob o pressuposto de mútua constituição entre instituições políticas e atores sociais, orienta a explicação de processos de institucionalização oriundos dessa codeterminação e de construção de encaixes institucionais no Estado. Contudo, o enfoque remete a produção de domínios de agência para processos endógenos à dinâmica de interação socioestatal correspondente, donde resulta a construção das instituições e das capacidades dos atores. Este capítulo busca iluminar elementos dessa endogenia, explorando os mecanismos de construção de encaixes institucionais e domínios de agência, e identificando seu perfil configuracional a partir de estudo de caso emblemático do processo de institucionalização no Brasil pós-transição.

A contribuição deste capítulo consiste assim em analisar o processo histórico de construção de encaixes institucionais e domínios de agência, em face de dinâmicas de institucionalização e de interação socioestatal, com base na trajetória de uma organização do movimento popular urbano no Espírito Santo, denominada Fams (Federação das Associações de Moradores da Serra). A Fams representa um caso emblemático do processo de institucionalização que também ocorreu em outros movimentos e organizações, no contexto brasileiro posterior à redemocratização. Seus encaixes institucionais se tipificam em acessos, órgãos, regras, cargos e instrumentos de participação na gestão pública municipal, abarcando desde o orçamento participativo, os conselhos e conferências de políticas públicas, o plano plurianual e plano diretor urbano, até a criação de órgãos em secretarias, a ocupação de cargos comissionados e o gerenciamento de programas e convênios governamentais. Importa indagar como o movimento social emergente no período de transição do regime autoritário, ao longo de três décadas, constrói encaixes, na mediação da relação sociedade-Estado, que con- 
ferem acesso mais permanente às instituições e alongam no tempo sua capacidade de influência?

Considerando que os encaixes institucionais derivam ou são construídos por processos históricos de interação socioestatal, este capítulo explora dois mecanismos de sua formação. $\mathrm{O}$ primeiro, relativo à gênese relacional do movimento social, consiste na relação com instituições na fundação do ator (Igreja católica e partidos políticos de esquerda) e a função dessas como "incubadoras institucionais" (Houtzager, 2004). Nesse caso, a interação com grupos religiosos e instituições partidárias na fundação da organização do movimento, ou seja, sua rede de relações pregressa com incubadoras, além de influir positivamente na construção de encaixes, conduz ao aprendizado institucional necessário à interação com instituições no contexto democrático. $\mathrm{O}$ segundo mecanismo se refere à permeabilidade do Estado (Marques, 2006) e sua mediação por coalizões partidárias e eleitorais. Esse acentua a interdependência entre movimentos sociais, partidos políticos e eleições na construção de encaixes institucionais (Skocpol, 1992). ${ }^{1}$ Assim sendo, "a capacidade de criar domínios de agência varia no tempo tanto pelo peso do passado quanto pela sensibilidade das instituições à transformação em momentos críticos (Gurza Lavalle, Houtzager e Castello, 2011, p. 51). Adicionalmente, este capítulo busca identificar o perfil configuracional do domínio de agência resultante do processo estudado, considerando três componentes - encaixes, capacidades organizacionais e interações socioestatais.

$\mathrm{O}$ argumento geral possui dois componentes. Primeiro: na construção histórica de encaixes e domínios de agência operam dois mecanismos que tencionam a ideia de autonomia dos movimentos sociais como ausência de relação com instituições, (i) as

1 Esta abordagem enfoca a relação dos movimentos sociais com as instituições na explicação das interações socioestatais e da institucionalização, ainda que o comportamento dos movimentos seja também moldado pela sua dinâmica interna e por fatores culturais. 
incubadoras institucionais na rede de relações pregressa do movimento e o aprendizado decorrente e, (ii) as coalizões partidárias-eleitorais e seu papel na permeabilidade do Estado. Segundo: os padrões organizacionais do ator social e de interação com o Estado se associam à construção de encaixes que, por sua vez, constituem o perfil configuracional do domínio de agência. Tecidos sob encaixes no Estado, capacidades organizacionais e padrões de cooperação com as instituições, os domínios de agência prolongam no tempo a influência dos atores sociais, dada a exclusividade de acesso ao Estado e a legitimidade de agir em políticas específicas.

Em termos metodológicos, o estudo em profundidade da trajetória da Fams se baseia em análise histórica longitudinal dessa organização do movimento popular urbano, ao longo de um continuum temporal de três décadas (1980-2010), com ênfase no seu padrão organizacional e de interação com o Estado com vistas a influenciar o processo político. $\mathrm{O}$ modelo analítico buscou explorar os mecanismos intervenientes na construção de encaixes e domínios de agência desde a fundação do ator no contexto de redemocratização, caracterizando o perfil configuracional deste no período pós-transição, decorrente do processo histórico de interação e de institucionalização. A investigação densa da Fams foi favorecida por perspectiva multi-method, que conduziu a combinação entre instrumentos do método qualitativo e quantitativo, a saber: (1) pesquisa documental formada por 138 arquivos selecionados no acervo da organização do movimento popular; (2) entrevista em profundidade com quatro atores-chave da Fams; e (3) survey de questionário semiestruturado aplicado a 28 ativistas da Fams, selecionados por meio de amostra não aleatória que considerou a posição de centralidade do ator no movimento. Os dados provenientes desses diferentes instrumentos metodológicos foram agrupados em torno de temas a fim de verificar a triangulação das 
evidências e promover a validação dos resultados a partir de linhas convergentes de investigação. ${ }^{2}$

O capítulo segue estruturado em três partes. Após esta introdução, a primeira seção discute a relação entre movimentos sociais e instituições nas teorias dos movimentos sociais, com destaque às contribuições da literatura que atenta para as interações socioestatais no contexto de institucionalização. A segunda analisa o processo histórico de construção de encaixes e domínio de agência pela Fams e seus mecanismos, como as relações com incubadoras institucionais e seus aprendizados, e as alianças partidárias e eleitorais no contexto de permeabilidade estatal. Finalmente, a terceira seção analisa as configurações do domínio de agência da Fams no pós-transição, caracterizada pela institucionalização de encaixes no Estado, por mudanças nas capacidades organizacionais do ator e no seu padrão de interação socioestatal voltado à influência na política pública.

\section{Abordagens sobre a relação entre movimentos sociais e insti- tuições políticas}

A análise das interações entre os movimentos sociais e as instituições políticas permanece subdesenvolvida nas Teorias de Movimentos Sociais (TMS), pois carece de instrumentos conceituais e metodológicos adequados para explicar essas relações em

2 Para maiores informações sobre o desenho de pesquisa, o perfil dos entrevistados, a estrutura do survey e a listagem completa dos documentos examinados da Fams, vide Apêndice Metodológico e Referências Documentais no livro Movimentos sociais e instituições participativas: efeitos do engajamento institucional no contexto pós-transição (Carlos, 2015b), também presente na tese de doutorado da autora (Carlos, 2012). Cabe destacar que o estudo mencionado analisa comparativamente, além da Fams, outras três organizações de movimentos sociais, a saber, o Centro de Defesa dos Direitos Humanos da Serra (CDDH), o Conselho Popular de Vitória (CPV) e a Associação Capixaba de Proteção ao Meio Ambiente (Acapema), localizados na região metropolitana do Espírito Santo. 
sua complexidade e multidimensionalidade. ${ }^{3}$ Por sua vez, as abordagens que buscam explicar o comportamento e a trajetória dos movimentos sociais a partir de sua relação com as instituições e elites políticas podem oferecer uma contribuição nesse sentido. Após longo hiato, trazer as instituições políticas de volta à análise das interaçóes sociais consiste em relevante complemento às teorias tradicionais de movimentos sociais.

A incorporação sistemática do Estado e das instituições, dos partidos políticos inclusive, nos quadros analíticos de movimentos sociais implica no reconhecimento da interdependência e mútua constituição entre Estado e sociedade civil. Desse modo se distancia das TMS que supõem uma separação rígida entre esses e a política institucionalizada e analisam a ação coletiva a partir de modelos dicotômicos: protesto-institucionalização, outsider-insider, conflito-cooperação, autonomia-cooptação. A Teoria do Processo Político desenvolveu as teses mais influentes acerca da "institucionalização do movimento", concebida como a sua integração às estruturas do Estado, a mudança no repertório de confronto e a busca de benefícios concretos por meio da negociação e acordo (Tarrow, 1997; McAdam, Tarrow e Tilly, 2001). A institucionalização do movimento produziria efeitos de complexificação em sua estrutura organizacional, expressos pela rotinização, burocratização, profissionalização e desmobilização da ação coletiva (Meyer e Tarrow, 1998; Kriesi, 1999; Piven e Cloword, 1979; McCarthy e Zald, 1973). Porém, o modelo dicotômico e conflitivo que abarca essas TMS, além de descuidar da diferenciação nos padrões organizacionais, obstou a compreensão das interconectividades entre movimentos e instituições e da heterogeneidade dos efeitos da institucionalização sobre os atores e as políticas. Conforme argumentam Abers e von Bülow (2011), a separação analítica rígida entre

3 Para uma discussão ampliada das teorias dos movimentos sociais e de suas limitações à explicação das relações desses com o Estado, vide: Carlos (2015c). 
sociedade e Estado restringe a compreensão dos movimentos em processos de interação com atores institucionais, pois inibe esses teóricos de explorar a diversidade de conexões entre movimentos sociais e o sistema político, mantendo invisíveis certos tipos de relações entre atores coletivos e o Estado.

Ao contrário desses, os estudos acerca da interpenetração entre movimentos e instituições acentuam que a estrutura das instituições e a dos movimentos sociais são mutuamente influenciadas, e que muitos movimentos interagem, constituem relações e formam alianças com agências do Estado, partidos políticos e grupos religiosos (Goldstone, 2003; Giugni e Passy, 1998; Hanagan, 1998; Mische, 2008). Embora alguns movimentos se identifiquem como revolucionários claramente outsiders e como opositores às instituições estabelecidas, muitos outros mantêm relações ativas com atores políticos e institucionais, em diferentes contextos históricos e em processos dinâmicos de mútua constituição.

O reconhecimento das interações entre os atores societários e as estruturas diversas é imprescindível à adequada compreensão da complexidade e diversidade dos movimentos, defende Mische (2008). Nesse sentido, as possibilidades de relações dos movimentos com o Estado não são reduzidas às interações de poder conflituosas, mas abarcam as conexões cooperativas ou colaborativas entre os atores em torno da produção de políticas públicas ou de alianças com partidos políticos (Goldstone, 2003; Giugni e Passy, 1998; Hanagan, 1998). Ainda que a visão de movimentos sociais como uma forma específica de contentious politics não deva ser abandonada, é preciso admitir que movimentos sociais se engajam em um conjunto de atividades que não necessariamente implica em relação de conflito com os detentores de poder. Em sociedades complexas, movimentos também cooperam com o Estado, especialmente na solução de problemas públicos, na elaboração e na implementação de políticas. Os movimentos sociais assim “intervém nos processos políticos de duas formas: desafiando as 
políticas ou propostas existentes e colaborando na elaboração e implementação de políticas governamentais" (Giugni e Passy, 1998, p. 82).

Em consonância com esse enfoque, os estudos brasileiros recentes têm contribuído para a compreensão das interações entre movimentos sociais e instituições. Esses demonstram que, no contexto pós-transição de institucionalização dos canais de mediação, os movimentos sociais combinam uma diversidade de padrões de interação com o Estado em termos de cooperação, conflito e autonomia que prescindem da desmobilização (Carlos, 2017; 2015a; 2015b; 2012), incluindo táticas institucionalizadas como a ocupação de cargos públicos (Dowbor, 2012). Em complemento, Silva e Oliveira (2011) demonstram que padróes complexos de relações entre sociedade civil e Estado, mediadas por partidos políticos de esquerda, constituem um "trânsito institucional" que favorece a institucionalização de demandas do movimento. Ao contrário das interpretações de negação e externalidade em face da institucionalidade política, predominantes no contexto de redemocratização do país, esses autores constatam um padrão de intersecção entre movimentos e Estado impulsionado pelo trânsito de militantes para agências governamentais (Silva e Oliveira, 2011).

Em seu estudo, Abers, Serafim e Tatagiba (2014) demonstram que a variedade de formas de relação dos movimentos sociais com o Estado compreende "repertórios de interação", nos quais incluem-se um conjunto de rotinas - protesto, participação institucional, política de proximidade e ocupação de cargos públicos. Conforme explicam as autoras, os repertórios de interação "permitem uma combinação criativa de tradições históricas de interação Estado-sociedade em modos que promoveram novas formas de negociação e diálogo" (Abers, Serafim e Tatagiba, 2014, p. 346). A compreensão da multiplicidade de modalidades de relação do movimento social com o Estado constitui relevante contribuição à literatura. Dentre outras, isto indica que nas interações com o 
Estado o movimento pode combinar o engajamento em instituições participativas com uma diversidade de repertórios de atuação, na finalidade de direcionar as suas demandas ao Estado e influir na agenda política. Explicar as diversas modalidades de interdependência nas interações socioestatais e avaliar as suas consequências para os atores e as políticas, constitui importante desafio para a agenda de pesquisa que busca incorporar o Estado e as instituições nos quadros analíticos dos movimentos sociais (Gurza Lavalle e Szwako, 2015). ${ }^{4}$

Neste propósito, o conceito de incubadores institucionais (Houtzager, 2004) assume relevo na explicação das relações entre movimentos sociais e instituições políticas. "Incubadores institucionais são atores da elite que estimulam e apoiam a formação de grupos e vão além do papel tradicional dos aliados dos movimentos" (p. 166). Isso significa que as elites e instituições políticas podem assumir o papel de incubador institucional para o movimento social contencioso, influenciando a formação de atores, em particular de grupos pobres sem recursos e politicamente marginalizados, porque incidem na superação dos obstáculos da ação coletiva. Diferente dos aliados que se restringem ao apoio aos movimentos existentes, os incubadores buscam criar e organizar novos movimentos, reconstruindo clivagens políticas e reorientando a contestação política. Ao fazê-lo, as instituições incubadoras atraem participantes para seus campos ideológico e organizacional e redefinem as bases de agrupamentos existentes. De modo intencional e crucial os incubadores contribuem para as redes sociais locais, os recursos organizacionais e as estruturas ideológicas necessárias para mitigar os obstáculos da ação coletiva, impactando de modo substantivo a formação organizacional e identitária dos atores so-

4 Para uma análise dos efeitos das interações entre movimentos sociais e Estado sobre os padrões de ação coletiva, vide Carlos (2012, 2015b, 2017). Os impactos dessas relações socioestatais sobre o Estado foram examinadas por Abers e Keck (2013), e sobre a política pública de habitação por Tatagiba e Teixeira (2016). 
ciais (Houtzager, 2004). No estudo do movimento sindical rural o autor demonstra que setores progressistas da Igreja católica, a CUT e o PT assumiram o papel de incubadoras institucionais para o "novo sindicalismo", com impacto significativo sobre suas identidades coletivas e organização no contexto de fundação. Em última instância, realça o papel do Estado e das instituições políticas na formação da ação coletiva e na construção de redes associativas nos setores marginalizados, influindo tanto sobre as trajetórias quanto as identidades dos movimentos, com implicações sobre a nossa compreensão das relações entre Estado e sociedade.

À medida que agentes estatais e organizações da sociedade política desempenham papel fundamental na formação de atores coletivos e da vida associativa, em diversos contextos, sua incorporação aos quadros analíticos dos movimentos sociais contribuirá para a compreensão das relações desses com o Estado e as instituições, e dos processos de institucionalização voltados à influência política.

\section{A construção histórica de encaixes institucionais e domínio de agência}

O processo histórico de construção de encaixes institucionais e domínio de agência pela Federação das Associações de Moradores da Serra (Fams) remete aos anos 1980 e 1990 e marca seu desfecho nos 2000. Neste decurso operam dois mecanismos: (i) as relações pregressas do movimento contencioso com incubadoras institucionais e o aprendizado resultante; (ii) as alianças com partidos políticos e coalizões eleitorais, e seu papel na permeabilidade do Estado às demandas dos atores coletivos. Recuperar esses dois mecanismos do processo constitutivo de encaixes e domínios de agência é o intuito desta seção. 
3.1 Gênese relacional, incubadoras institucionais e aprendizado na Fams

A gênese relacional do movimento popular da Serra consiste na sua rede de relações pregressa com setores religiosos progressistas e instituiçõoes partidárias de esquerda, composta ainda por outros movimentos sociais e organizações civis. Com efeito, a Igreja católica e o Partido dos Trabalhadores restaram influentes na formação organizacional e identitária do movimento popular porque assumiram o papel de incubadoras institucionais. Nesta seção busca-se argumentar que a relação com incubadoras institucionais na formação do movimento, mediada pela multifiliação de ativistas, gerou aprendizados que favorecem sua propensão a interagir com o Estado e a construir encaixes no contexto pós-transição.

A Fams surgiu em 1980 a partir do trabalho de organização popular das Comunidades Eclesiais de Base (CEBs) e das Pastoral Operária e Pastoral Juventude para o Meio Popular da Igreja católica, do grupo de mulheres atualmente Associação de Mulheres Unidas da Serra (Amus) e das comissões temáticas de moradores, de saúde e de educação. Autodenominada "movimento popular", a Fams congregou uma rede de movimento social composta por múltiplas organizações e atores em interação, sendo essas, associações de moradores, grupo de mulheres, grupo de operários, grupo de jovens e outras entidades do município com objetivos semelhantes. A motivação para a fundação dessa organização federativa teve um duplo caráter, o organizacional (unificar, articular e fortalecer os segmentos comunitários) e o reivindicatório (melhorias sociais e urbanas) orientado para o Estado. Atualmente, possui

5 Também chamados "movimentos populares urbanos", que incluem os movimentos de bairros, vilas e favelas, organizados por entidades (associação de moradores, movimentos comunitários, conselhos populares) ou por lutas específicas, a nível regional ou nacional, transporte, solo urbano, moradia etc. (Gohn, 1988). 
uma estrutura federativa com 125 associações de moradores e suas principais realizações correspondem a setores das políticas sociais, nas áreas de saúde, infraestrutura urbana, transporte coletivo, educação, moradia e meio ambiente.

$\mathrm{Na}$ visão dos ativistas, a formação de um movimento federativo, em nível municipal, que agregasse e articulasse as associações de bairros dispersas, fragmentadas e enfraquecidas constituía estratégia eficiente para o reconhecimento de sua legitimidade enquanto canal de mediação da relação entre o Estado e a sociedade civil. Por conseguinte, as reivindicações por saneamento, transporte, educação, calçamento, saúde e meio ambiente seriam alcançadas por intermédio da organização popular e da defesa dos direitos sociais; ao contrário das práticas políticas então vigentes que vinculavam a aplicação de recursos públicos à intermediação de grupos conservadores. Para os ativistas, não bastava criar uma organização comum aos movimentos, unificadora das bandeiras de lutas e avessa a relações políticas de favor e troca. Era necessário estruturar as associações existentes e criar outras novas, construí-las formalmente, propor formas organizacionais que favorecessem a participação no processo decisório, o debate dos temas, problemas e soluções, o posicionamento diante de interesses e ideias contrárias e o exercício da liderança com representatividade. Enfim, era necessário um longo e sistemático trabalho de educação política voltada à prática democrática, de politização e de conscientização da importância da organização popular e da elaboração da noção de "direitos a ter direitos". ${ }^{6}$

Ativistas, movimentos sociais, segmentos religiosos e partidos políticos de esquerda atuaram nesse trabalho de organização e politização do movimento popular da Serra. Especialmente a relação com a Igreja católica e o Partido dos Trabalhadores (PT), além

6 O potencial dos movimentos sociais, das décadas de 1970 e 1980, na renovação dos padrões socioculturais, se expressou sobretudo na questão dos "direitos a ter direitos" (Telles, 1994) e de uma "nova cidadania” (Dagnino, 1994). 
de integrantes do movimento estudantil, do movimento sanitarista, do movimento de direitos humanos, do movimento operário e do Partido Comunista Brasileiro (PCB). Essas diferentes expressões políticas atuaram na formação da Fams, manifestando consensos, dissensos e tensões que deram a dinâmica do movimento e influenciaram a sua gênese relacional, organizacional e identitária.

A Igreja católica, por meio das CEBs e dos programas pastorais, contribuiu decisivamente para a formação do movimento popular na Serra e influenciou sua condução por intermédio de ativistas multifiliados que participavam, ao mesmo tempo, de comunidades eclesiais de base, de movimentos de bairro, de partidos políticos de esquerda, de movimentos de oposição sindical além de outras entidades sociais. É mister ressaltar o caráter informal, descentralizado e não institucionalizado dessas relações, em grande medida, articuladas por "ativistas multifiliados" que se engajam e entrecruzam movimentos e instituições (Mische, 2003). ${ }^{7}$

No setor progressista, a Igreja católica assumiu o papel de incubadora institucional para o movimento popular urbano. Sua contribuição se estende desde a organização dos primeiros grupos de trabalho na periferia da cidade até a criação da Federação das Associações de Moradores da Serra e muitos ativistas a reconhecem como o berço fundacional do movimento popular. $\mathrm{Na}$ concepção dos agentes das CEBs a construção de uma nova sociedade na qual as mazelas sociais fossem sanadas passava pela organização popular e pela autonomia dos movimentos na relação com os poderes constituídos. No processo formativo de educação popular que empreenderam para as lideranças comunitárias os temas da democracia de base, da capacidade política das classes populares e da sua autonomia do Estado assumiram enfoque principal. Essa estrutura ideológica que a Igreja forneceu foi fundamental para seu

7 No contexto de transição democrática, a relação de movimentos sociais com setores da Igreja católica e com o Partido dos Trabalhadores foi identificada por estudiosos. Vide, respectivamente, Doimo (1995) e Sader (1988). 
papel de incubadora institucional do movimento popular urbano porque traduziu novo conteúdo em identidades preexistentes. Por seu turno, a formação de líderes comunitários que coordenavam uma variedade de atividades religiosas e sociais foi crucial para superar o obstáculo de recrutar e formar ativistas do movimento. Além de fornecerem experiência e infraestrutura organizacional, capacitação de lideranças e arcabouço ideológico-identitário, as CEBs e pastorais da Igreja contribuíram para expansão das redes sociais locais por meio da conexão entre as comunidades e dos laços entre as lideranças e suas bases.

A Igreja católica agregou ao programa de educação popular das CEBs alguns militantes de partidos e tendências políticas de esquerda que agiam clandestinamente. Com a emergência da Fams, esses ativistas - caracterizados pela multifiliação ao movimento popular, ao Partido dos Trabalhadores ${ }^{8}$ e ao Movimento pela Emancipação do Proletariado $(\mathrm{MEP})^{9}$ - acompanharam e assessoraram o movimento sistematicamente, imprimindo suas referências identitárias e ideológicas nesse espaço, ora em combinação, ora em conflito com os discursos da organização religiosa. Serpa (1990) denominou os agentes pastorais e os grupos políticos de esquerda que atuavam conjuntamente no assessoramento do movimento popular da Serra de "assessores pedagógicos", dado o trabalho de educação popular que realizavam na organização societária.

Discursivamente, esses assessores convergiam quanto à orientação do movimento, particularmente no ideal de "autonomia" das instituições políticas e do Estado e da organização democrática e de base. No entanto, as diferenças entre Igreja e partido político eram substantivas e alimentaram questões polêmicas - ser

8 O Diretório Municipal do PT, na Serra, foi criado em 1980.

9 O MEP foi uma tendência política de esquerda voltada à revolução socialista no país. Após a criação do PT, o MEP manteve-se na organização partidária como corrente política. 
ou não ligado à tendência política, imprimir ou não as orientações definidas por essas tendências nos movimentos - que estiveram na base das divergências desse grupo de assessores. Para os membros das CEBs, a aproximação entre o movimento popular e o ativismo partidário era indesejável, pois contrariava o ideal de autonomia das instituições políticas, ao passo que, para os partidários de esquerda, a Igreja não tinha uma proposta clara para os movimentos de modo que as comunidades eclesiais de base constituíam espaço inviável para o confronto político (Serpa, 1990). Por volta de 1980, os assessores vinculados ao PT e ao MEP iniciaram uma atuação independente das CEBs e criaram a Equipe de Apoio aos Movimentos Populares da Serra e Carapina. ${ }^{10}$ Numa certa simbiose entre o movimento social e o partido político, a Equipe de Apoio foi estruturada em torno do compromisso com o movimento de bairro, o movimento operário e a organização do PT na Serra.

As implicações da relação do movimento popular com a Igreja era tema debatido no Diretório do PT da Serra e na Equipe de Apoio ao movimento. Esse grupo reconhecia a importância do trabalho realizado pela Igreja no município e a percebia como aliada no duro contexto de transição para a democracia, entre outras razões, pelo despertar da liderança comunitária para o compromisso político, pelos treinamentos e capacitações organizados, pelo apoio às reuniões, seminários e publicações do movimento. Por outro lado, o grupo avaliou que a Igreja não era mais a única força política que atuava nos movimentos e a substituição do referencial cristão pela consciência de classe operária era fundamental à qualificação do movimento social, baseado em discussões acerca

\footnotetext{
${ }^{10}$ A Equipe de Apoio aos Movimentos Populares da Serra e Carapina foi formada por professores e estudantes da Universidade Federal do Espírito Santo (departamentos de Serviço Social e de Filosofia), que atuavam como ativistas multifiliados a movimentos sociais, partidos políticos e grupos de esquerda, no final da década de 1970 e anos 1980.
} 
das limitações da instituição eclesial e do referencial cristão para a luta política almejada.

A gênese organizacional e identitária da Fams assim foi constituída na interação com estas duas instituições incubadoras, a Igreja católica e o PT, os quais, apesar das diferenças, convergiam nos princípios de democracia de base e de "autonomia" das instituições políticas e do Estado. Na visão dos atores, aplicar o princípio da "democracia de base" evitava a centralização das atividades e do processo decisório, a personificação das conquistas alcançadas na figura do líder comunitário e o engessamento do movimento. Garantir a sua independência do sistema político significava romper com as relações patrimoniais e com o clientelismo que marcaram a relação das organizações sociais com partidos políticos e com os governos, evitar o uso de relaçóes pessoais como via de acesso aos bens públicos e se proteger das tentativas de cooptação. Esses princípios foram processados e reelaborados pelos ativistas em referências identitárias, discursivas e organizacionais, cujos aprendizados nortearam a ação do movimento popular ao longo do tempo.

$\mathrm{Na}$ relação com os partidos políticos e o Estado a "autonomia" constituiu o princípio discursivo de significativa difusão entre os movimentos sociais das décadas de 1970 e 1980, acompanhado da ideia de oposição e enfrentamento dos poderes constituídos. Naturalmente, as práticas políticas do movimento nem sempre convergiram para esse discurso de autonomia e oposição, o qual foi reelaborado em diferentes conjunturas políticas. A relação do movimento popular com os partidos políticos é marcada por tensões e ambiguidades. Por um lado, o movimento realizava críticas às instituições políticas conservadoras, ao interesse político-eleitoral dessas instituições e à manipulação e cooptação. Por outro lado, o movimento desenvolveu uma aproximação com os partidos políticos e tendências políticas de esquerda, mediada pela 
afinidade entre seus projetos políticos. ${ }^{11}$ Desses últimos, absorveu-se o projeto político de transformação da sociedade, o discurso de que a questão política reflete a luta de classes e o discurso de oposição às instituições e ao Estado como forma de constituição da sociedade autônoma. Os membros do movimento, ao mesmo tempo em que cultivavam uma relação desejável com esses atores políticos, recusavam relacionar-se formalmente com a instituição da qual esses atores eram representantes, a fim de evitar a marca do partidarismo no movimento.

Essa relação ambígua entre o movimento e os partidos políticos se ancorava em discursos de "pureza" e "pluralismo" do primeiro frente ao segundo. $\mathrm{O}$ movimento se autoproclamava apartidário, baseado na defesa da sua não instrumentalização (ou aparelhamento) pelos partidos políticos e na sua autonomeação como representante dos interesses populares, sem qualquer sectarismo ou discriminação de credo religioso, ideologia ou filiação partidária (Fams, 1986, doc. 24).

O movimento precisava apresentar uma face neutra diante da administração pública, a fim de colocar-se como representante de um grupo abrangente da sociedade, sendo, nesse sentido, mais amplo que um partido. ${ }^{12}$ Como afirmam os ativistas: "a Fams e o movimento popular não têm donos, nem partido político; é movimento do povo, cuja preocupação é o interesse e as necessidades do mesmo" (Fams, 1983, doc. 9). Isso também significa, para os ativistas, uma tentativa de delimitar os espaços de atuação e garantir o direito de organização popular fora das instituições políticas, o que implica a recusa da mediação dos canais tradicionais na relação

11 Para a noção de projeto político, vide Dagnino (2002). A autora ressalta a importância da afinidade ou coincidência entre os diferentes projetos políticos $\mathrm{da}$ sociedade civil e da sociedade política, incluso o Estado.

12 Como explica Cardoso (1988, s/p): “Todas as associações sabem que devem manter uma aparência e um discurso apolítico, mesmo quando sua prática as desmente. Não podem tomar partido porque representam a todos". 
com o Estado e a busca de uma relação direta e sem intermediação entre o movimento e o Estado. Manter o discurso de apartidarismo foi também necessário para evitar divisões internas prejudiciais ao movimento, o que é comum quando se vincula a uma sigla partidária. No discurso do movimento, "o partido cria divisões e o movimento precisa construir o consenso, a unidade, a identidade comunitária"', condição essa necessária ao fortalecimento dos grupos organizados que o compõem.

A autonomia dos partidos políticos e o apartidarismo é uma postura política expressa em nível discursivo e referente à relação de independência do movimento do sistema partidário. No nível das práticas, porém, a relação com os partidos é identificada em duas modalidades. Em primeiro lugar, a relação se manifesta no plano ideológico na medida em que crenças, ideias e ideologias são comuns a ambas as organizações e lhes conferem uma afinidade de sentido. Essa conexão ideológica entre movimento e partido é intermediada pela multifiliação de ativistas que atuam concomitantemente nesses espaços, os quais ativam um processo de influência mútua de seus discursos e práticas. Em segundo lugar, a relação do movimento com partidos políticos se estabelece no nível pragmático por meio da construção de apoios ou alianças políticas, especialmente em dois contextos. No pleito eleitoral para cargos no executivo e legislativo, quando o movimento estabelece apoio político-eleitoral a partidos considerados aliados das causas populares, por exemplo, ao PT, PCB e segmentos do PMDB no início da década de 1980. E na eleição da nova diretoria do movimento, ocasião em que as disputas e alianças para a formação das chapas sofrem a interferência de partidos políticos representados no movimento por ativistas multifiliados. Nesse último aspecto, a relevância da Fams como movimento representativo dos interesses de amplos grupos da sociedade transformou-a em arena de disputas por influência política de partidos de diferentes conotações ideológicas. 
Essa relação do movimento popular com partidos políticos, ora mediada por afinidade ideológica, ora por interesse em aliança política, ou por ambas, significa que o padrão de recusa e oposição à institucionalidade política não é generalizado e nem indiscriminado. Ao contrário, o padrão é seletivo e intermediado pela avaliação do potencial da coalizão com os atores políticos com vistas a influenciarem a agenda pública. $\mathrm{O}$ movimento, assim, convive com o desafio cotidiano de apresentar uma face independente diante do Estado e de construir apoios e alianças político-partidárias para consolidação dos seus projetos. Em sua gênese, o padrão de interação seletivo com essas incubadoras institucionais não reduziu o potencial de contestação do movimento, nem significou a eliminação do conflito diante de segmentos conservadores do Estado.

Em suma, a Igreja católica e o partido político de esquerda foram incubadoras institucionais na emergência do movimento popular urbano, são parte da gênese relacional do movimento e influíram decisivamente na sua formação organizacional e identitária. O papel das incubadoras institucionais na formação do movimento social contencioso contradiz as visões simplistas de autonomia como ausência de relação com as instituições, assumindo a acepção um significado mais relacional e contingente. Particularmente as CEBs e o PT agiram intencionalmente na criação e consolidação do movimento, oferecendo suporte técnico e político à organização dos atores e promovendo debates e reflexões de impacto sobre as identidades. Por meio de dinâmicas educativas e da participação de ativistas multifiliados, as concepções e discursos enunciados e defendidos pelas incubadoras foram absorvidos e reelaborados em novos aprendizados pelo movimento, não sem divergências e tensões.

Esta seção buscou demonstrar que, sob condições de afinidade política, identitária ou ideológica, as instituições assumem o 
papel de incubadoras para o movimento social contencioso com escassez de recursos e politicamente marginalizado das decisões políticas (Houtzager, 2004). Esse processo formativo conduz ao estabelecimento de relações entre movimentos e instituições que os conectam numa estrutura relacional de atores e organizações que vão além do papel tradicional de aliados dos movimentos. À medida que criam e organizam novos movimentos, as incubadoras institucionais reconstroem clivagens políticas e reorientam a contestação política. A despeito da literatura comumente conceber as interações entre movimentos e instituições políticas como aliados e antagonistas, de modo dual, as incubadoras apontam uma configuração particular de relações entre movimentos e instituições, mutuamente constitutiva, pois mais que aliados formam identitária e organizacionalmente os movimentos contenciosos.

Argumenta-se que a relação pregressa com as incubadoras institucionais na fundação do movimento, intermediada por ativistas multifiliados, constitui um dos mecanismos do processo histórico de construção de encaixes e domínios de agência. Assim sendo, a interação do movimento social com instituições no contexto de fundação, como partidos políticos de esquerda e organizações religiosas, gerou aprendizado institucional e capacidades para construir encaixes na burocracia governamental, uma vez que o impacto significativo das incubadoras sobre as identidades e forma organizacional dos atores coletivos produziu aprendizados que favorecem sua predisposição para interações socioestatais, com vistas a influenciar o processo político. Por fim, o aprendizado decorrente da relação pregressa com as incubadoras favoreceu o reconhecimento pela Fams da legitimidade dos atores institucionais como interlocutores válidos. 


\subsection{Coalizão partidária e eleitoral e permeabilidade do} Estado

A relação do movimento social com incubadoras institucionais na sua fundação produz aprendizados que favorecem a construção de encaixes institucionais, conforme argumentado. Nessa dinâmica, o segundo mecanismo de construção de encaixes no Estado consiste nas coalizões partidárias-eleitorais e seu papel na permeabilidade estatal. Este vincula-se à relação histórica do movimento popular com os partidos políticos de esquerda e a permeabilidade governamental à proposta de participação social, os quais remetem à similaridade entre os diferentes projetos políticos que subjazem às relações entre a sociedade civil e o Estado. Resgatar o papel das alianças partidárias e eleitorais e da permeabilidade estatal na construção de encaixes institucionais é o intuito desta seção.

Esse elemento acentua o papel das alianças partidárias nas eleições para a construção de encaixes institucionais, conclamando a interdependência entre movimentos, partidos e eleições (Sckopol, 1992). Na Serra, o movimento popular constituiu vínculos orgânicos e ideológicos com partidos políticos de esquerda, particularmente o PT, em um processo de simbiose e constituição mútua conduzido por ativistas multifiliados ao movimento e ao partido, que foi influente na gênese de ambos. As relações de cunho ideológico e identitário entre o movimento e o partido conduziram ao apoio político da Fams às candidaturas do PT, nos pleitos eleitorais de 1982, 1988, 1992 e 1996, para o executivo local. Esses candidatos eram ativistas multifiliados ao partido e a Fams que atuaram ativamente na fundação do movimento e ocuparam posições de centralidade na sua direção. ${ }^{13}$

13 São eles: nas eleições de 1982, Salatiel Quiquita de Oliveira, nas eleições de 1988, Pedro Bussinger e de 1992, Brice Bragato. Essa última foi eleita vereadora no município da Serra nas eleições de 1988; dois anos depois eleita deputada 
Nos três primeiros processos eleitorais do período de transição democrática, o PT perdeu as eleições para políticos tradicionais do município que se revezavam no poder - José Maria Feu Rosa (Arena/PDS depois PMDB) e João Baptista da Motta (PMDB depois PSDB). No pleito de 1996, o PT perdeu as eleições para o candidato do PDT Sérgio Vidigal, apoiado por coligação partidária que reuniu antigos aliados do Partido dos Trabalhadores, como o PPS (outrora PCB) ${ }^{14}$ e o PSB. Nas competições eleitorais seguintes o PT deixou de apresentar candidatura própria e passou, juntamente com o PSB, a formar coalizão partidária com o PDT. O movimento popular, por sua vez, estendeu o apoio político-partidário e eleitoral ao PT à aliança então firmada com a coligação PDT-PT-PSB. Essa estratégia de composição eleitoral potencializou a construção de encaixes no governo municipal, porque incidiu na permeabilidade do Estado ao movimento e às suas demandas. ${ }^{15}$

Assim, as coalizões partidárias nas eleições municipais, associadas à permeabilidade estatal à proposta do movimento de implementar arranjos participativos na gestão pública municipal, se destacam como mecanismo para a construção de encaixes institucionais. De acordo com Marques (1999), "a permeabilidade é pro-

estadual e reeleita para os mandatos 1994-1998 e 2002-2006, pelo PT; em 2010, concorreu ao governo do estado pelo Partido Socialismo e Liberdade (PSOL).

14 O PT e o antigo PCB vivenciaram momentos de apoio mútuo no período de transição do regime autoritário, embora disputassem a hegemonia política e ideológica no interior da Fams. Em geral, ambos os partidos convergiam nos ideais de transformação da sociedade e de unificação das bandeiras de luta em nível municipal, mas polarizavam o debate no interior da Federação e produziam ora situações de consenso ora de conflito e disputa, sobretudo quanto a concepção de relação do movimento com o Estado.

15 Adicionalmente, são evidências da aliança entre o movimento e os partidos da base de sustentação do governo Vidigal: (i) a composição da chapa do executivo, no cargo de vice-prefeito, por ativistas multifiliados ao movimento popular e ao PSB, sendo Valter de Paula (2000 a 2008) e Madalena Santana Gomes (2009 a 2012); (ii) a coordenação de campanhas eleitorais de candidatos da base partidária aliada, por militantes da diretoria executiva da Fams. 
duzida a partir de uma teia de relações e cumplicidades construída ao longo da vida dos indivíduos, incorporando diferentes tipos de elos que se espalham por todas as dimensões do social" (p. 49). ${ }^{16}$ $\mathrm{Na}$ Fams, a construção de pontos de acesso à esfera governamental é tributária da luta histórica empreendida pelos atores sociais na implementação do Orçamento Participativo, a partir da ascensão de grupo político no poder local, conforme veremos.

Nada fortuita, a proposição de gestão participativa de políticas públicas ocupa papel singular na Fams desde sua fundação. Uma luta histórica pela construção de encaixes no Estado foi conduzida, com vistas à influência na agenda pública. Nesse movimento, o processo de construção de encaixes iniciou-se frente à perspectiva de um "novo estilo de gestão pública" do governo João Baptista da Motta, em dois mandatos políticos, na gestão 19831988, pelo PMDB, e no mandato 1993-1996, pelo PSDB. Ainda que essas experiências tenham sido efêmeras e pouco se convertido em resultados concretos, elas demonstram a predisposição da Fams em construir encaixes institucionais, em contextos de potencial permeabilidade das instituiçóes governamentais e de promessa do governo de reconhecimento da sua legitimidade como representante de grupos amplos da sociedade civil.

Resta mencionar que, neste contexto de transição do regime civil-militar, a propensão da Fams a participar da primeira gestão Motta valeu-se de sua heterogeneidade interna, da existência de conflitos e disputas ideológicas na organização do movimento e da influência dos militantes do PCB em sua direção. ${ }^{17}$ Essas divergên-

16 O autor enfatiza o caráter não intencional da permeabilidade do Estado como efeito construído "ao longo das trajetórias dos indivíduos e das organizações e marcado por intensa dependência da trajetória", ainda que admita que "seja possível delimitar regióes específicas das redes produzidas de forma intencional e orientada a lesar o Estado" (Marques, 2006, p. 33).

17 O PT da Serra participou das eleições de 1982 lançando candidatura própria para o executivo municipal, estadual e cargos no legislativo. Já o PCB apoiou o candidato do PMDB João Baptista da Motta. Vale lembrar certa afinidade 
cias entre os ativistas multifiliados ao movimento e aos partidos políticos PT e PCB quanto à relação com o Estado foram, momentaneamente, suprimidas, em virtude das expectativas diante do novo governo.

Na sua primeira gestão (1983-1988), Motta foi eleito com o discurso de participação popular na gestão pública, o que convergia com o ideal do movimento de controle social das políticas públicas e do orçamento municipal. A crença nesse processo conduziu a eleição da chamada "chapa do consenso" para a coordenação geral da Fams (1983-1985), e monopolizou os seus trabalhos em torno da discussão, crítica e proposição ao programa de governo do prefeito Motta. A ideia predominante era que as propostas para a municipalidade deveriam emergir da sociedade civil mediante um processo orgânico e autônomo de tomada de decisões em assembleias ampliadas e em seminários, capaz de conferir legitimidade às proposições encaminhadas ao poder público.

Os movimentos populares, articulados pela Fams, discutiram e elaboraram propostas de políticas públicas setoriais (transporte coletivo, saúde, educação, cultura e turismo) e de canais de participação social na gestão pública (Fams, 1983, doc. 9). Muito se debateu sobre a criação do conselho comunitário que estabeleceria a mediação entre as organizações societárias e o Estado, além do conselho de saúde, de educação e de transporte. Os ativistas expressavam constantemente o desconhecimento da maneira como se concretizaria a cogestão entre agentes estatais e segmentos da sociedade civil e, nesse aspecto, era tema recorrente nas discussões a desconfiança e o receio de a proximidade com o governo provocar o atrelamento do movimento e a perda de autonomia. No documento intitulado "Propostas da Fams para o Prefeito Motta", recomendam:

do PCB com a ala do PMDB que acolheu seus militantes quando atuavam na clandestinidade. 
O conselho municipal [comunitário] deverá ser formado por legítimos representantes dos bairros e escolhidos pela associação, que dentro do bairro deverá ser autônoma e por isto mesmo terá que sempre reunir com outros movimentos do mesmo bairro na tentativa de se tirar reivindicações consensuais que serão apresentadas ao conselho. Este deverá ainda ter espaço para participação de representantes de movimentos que sejam de nível municipal como: grupo de operários da Serra, por exemplo. Outro fator importante é que este conselho deverá ter autonomia, sendo, portanto, desatrelado da prefeitura. Nos bairros onde não existirem associações, estas deverão ser criadas com incentivo do conselho e da prefeitura e enquanto não se criarem tais associações, os representantes do conselho nestes bairros sairiam das comunidades de base local ou de outra legítima entidade representativa dos moradores (Fams, 1983, doc. 9).

Entretanto, essa relação de proximidade com o governo Motta foi transitória, pois o movimento recuou já no terceiro ano de sua administração, em 1985, quando avaliou que o governo não estava efetivamente interessado em promover uma política de participação popular. ${ }^{18}$ Isso porque esse governo não priorizou a área social, não implementou projetos e propostas advindas dos debates populares, e nem reconheceu a legitimidade do movimento de bairro, ao contrário, estava "atuando até no sentido de desmobilizar os movimentos combativos, atraindo lideranças ou apoiando grupos nos bairros com o único objetivo de criar uma base de sustentação à sua política” (Fams, 1986, doc. 24). Essa avaliação negativa do comprometimento do governo produziu reposicionamentos no interior do movimento e reelaboração discursiva, a

18 Segundo Serpa (1990), já em 1984 muitas lideranças dos bairros vão se definindo pelo PT e retomando antigas reivindicações. O prefeito Motta reage, com cooptação e incentivando o paralelismo. O PCB deixa o governo e passa a denunciar sua política. 
qual visava reeditar os princípios orientadores da ação coletiva de sua época fundacional, como o ideário de autonomia do sistema político e de organização democrática das bases, naturalmente, não desprovidos de reconfigurações e adaptações ao contexto de redemocratização.

No que diz respeito a segunda gestão Motta (1993 a 1996) foi estabelecida nova dinâmica de interação entre a Fams e o governo com vistas a construção de encaixes institucionais, diante de nova promessa velada de "gestão participativa". Para o movimento popular, a conjuntura posterior a Constituição Federal de 1988 exigia ações mais democráticas e participativas da administração pública e, por isso, concentrou o seu plano de lutas na implementação do Orçamento Participativo (OP). Em 1993, a Fams coordenou a mobilização dos moradores para levantamento de prioridades nos bairros e editou a primeira versão do orçamento participativo da Serra a partir de metodologia elaborada pela própria Federação em articulação com outras entidades societárias e alguns técnicos governamentais. No mesmo ano, a câmara municipal aprovou a Lei de Diretrizes Orçamentárias que garantiu a participação do movimento popular na discussão do orçamento municipal. Em 1994, o movimento aprovou na câmara de vereadores e o prefeito sancionou o principal instrumento de sustentação legal do OP, denominado Assembleia Municipal do Orçamento (AMO), pela Lei n.1788/94. A mobilização dos moradores, eleição de delegados, escolha das prioridades e deliberação acerca da proposta orçamentária ocorreram nos anos seguintes desse governo pela instituição dessa Assembleia Municipal do Orçamento. ${ }^{19}$

19 Os esforços da Fams para implantação do orçamento participativo não se restringiram a essa gestão, mas remontam à primeira administração de Motta, em 1987, quando o movimento apresentou à câmara municipal um pré-projeto de lei que garantia a discussão popular no orçamento municipal; e ao governo que se seguiu, de José Maria Feu Rosa (1989-1992), em 1991, quando realizou a discussão do orçamento com mais de trinta associações de moradores, à revelia desse executivo local. Ver Carlos (2015). 
A execução dos investimentos orçamentários, contudo, foi sucessivamente ignorada pelo executivo local, que tendeu a não reconhecer aquele processo participativo e a deslegitimar as deliberações societárias. A despeito da organização popular e da coordenação das entidades da sociedade civil pela Fams, o descomprometimento do governo com o orçamento participativo frustrou maiores êxitos e resultados dessa ação, resguardado o aprendizado político e pedagógico oriundo da participação em si. A ausência de coincidência e compatibilidade entre os projetos políticos da sociedade civil e do Estado e, por conseguinte, de permeabilidade estatal, incidiram negativamente sobre a construção de encaixes com possibilidade efetiva de influir nas políticas públicas. ${ }^{20}$

Embora imerso em iniciativas malogradas, esse processo histórico de construção de encaixes institucionais habilitou os atores societários a arquitetar pontos de acesso e de influência política no Estado, em contexto de permeabilidade governamental mediado por composição partidário-eleitoral, conforme veremos na seção seguinte. Isso se concretizou a partir das eleições municipais de 1996, com a aliança da Fams à coligação partidária PDT-PTPSB, acentuando a interdependência entre movimento, partidos e eleições na construção de encaixes. ${ }^{21}$ Importa destacar o significado simbólico dessa conjuntura para os ativistas da Fams, qual seja, o "de finalização de uma era de autoritarismo, corrupção e clientelismo nos rumos da vida política local" e o limiar da fase "de instituição e avanço da democracia participativa e popular na gestão pública da Serra” (Fams, 2009, p. 7, doc. 135). Para o movimento, essa mudança representou a absorção de reivindicações históricas na agenda política, especialmente quanto à gestão par-

20 Por outro lado, as promessas estatais não cumpridas podem incentivar a ação coletiva aos moldes de oportunidades não-intencionais criadas pelo Estado (Houtzager, 2004, p. 28).

21 A coalizão partidária PDT-PT-PSB seguiu, na Serra, por quatro mandatos consecutivos (1997 a 2012). 
ticipativa na administração pública. Conforme assinalam, o orçamento participativo é uma conquista do movimento popular que foi precedida de lutas, avanços e recuos na negociação com a esfera governamental.

\section{Encaixes institucionais e domínio de agência: perfil configu- racional no contexto pós-transição}

O aprendizado institucional oriundo da construção histórica de encaixes via democracia participativa, particularmente a proposição embrionária de conselhos comunitários de políticas públicas e os primeiros experimentos de $\mathrm{OP}$, qualificam os atores societários a arquitetar pontos de acesso no Estado com capacidade de influência no processo político, alcançando a autorização governamental e a legitimidade na representação de segmentos da sociedade civil.

No Brasil pós-transição é notório um processo de engajamento institucional de movimentos sociais e atores da sociedade civil na formulação e implementação de políticas públicas. Subjazem a esse fenômeno a multiplicação de instituições participativas nos três níveis de governo, bem como a gestão de convênios e programas governamentais por organizações da sociedade civil. Esse engajamento societário em instituições participativas e agências governamentais remete à habilidade e à predisposição dos atores a arquitetar seu encaixe institucional, no contexto político de oportunidades e constrangimentos, isto é, concerne à permeabilidade do Estado e aos projetos políticos dos governos, às alianças e clivagens partidárias, às relações entre o Executivo e o Legislativo.

A construção de encaixes institucionais pelos atores coletivos compreende um processo histórico, conforme visto. Na Fams consubstanciou-se por meio da institucionalização de arranjos participativos de intermediação da relação entre sociedade civil e Estado, a partir de meados da década de 1990. Os encaixes 
construídos pelo movimento popular e autorizados pelo poder público correspondem à implementação de instrumentos de participação no nível municipal, tendo como principal interlocutor o Executivo e, em menor proporção, o Legislativo e setores privados. $\mathrm{O}$ conjunto de encaixes institucionais forjados no Executivo municipal abarca o orçamento participativo, os conselhos municipais de políticas públicas, as conferências setoriais, o plano plurianual e o plano diretor urbano participativo, o gerenciamento de programas de participação social e de convênios governamentais e a ocupação de cargos comissionados nos órgãos de execução dos mecanismos de participação. O Quadro 1 descreve essa configuração de encaixes na Fams.

A capacidade de influência política dos encaixes foi potencializada pelo estabelecimento de convênios, contratos e termos de parceria com órgãos do governo e empresas privadas, que viabilizaram a infraestrutura, a contratação de serviços técnicos especializados e o desenvolvimento das atividades do movimento. Os convênios foram destinados a cursos de capacitação de lideranças populares, ao aluguel da sede da organização do movimento e a projetos culturais, ao passo que os termos de parceria sustentaram projetos de comunicação social, projetos educacionais e a participação em congressos de outras entidades. Entre esses contratos, destaca-se o repasse de recursos do governo municipal para a Fams coordenar os programas de participação popular na gestão pública, como a instalação anual da Assembleia Municipal do Orçamento (AMO) que regula o OP e as discussóes do Plano Plurianual (PPA) e do Plano Diretor Urbano participativo (PDU). (Quadro 1). 


\section{Quadro 1: Encaixes institucionais da Fams no governo municipal (1997 a 2010)}

\begin{tabular}{|c|c|c|}
\hline Tipos de encaixes & Descrição & Período \\
\hline Orçamento participativo & $\begin{array}{l}\text { Participação e representação como de- } \\
\text { legados nas assembleias do OP }\end{array}$ & 1997 a 2010 \\
\hline Conselhos gestores & $\begin{array}{l}\text { Representação como conselheiros nos } \\
\text { seguintes conselhos gestores de polí- } \\
\text { ticas públicas: Conselho Municipal } \\
\text { de Educação, Conselho Municipal } \\
\text { de Meio Ambiente, Conselho } \\
\text { Municipal de Política Urbana ou do } \\
\text { Plano Diretor Urbano, Conselho } \\
\text { Municipal de Habitação, Conselho } \\
\text { Municipal de Turismo, Conselho } \\
\text { Municipal Interativo de Segurança } \\
\text { ou de Segurança Urbana, Conselho } \\
\text { Municipal de Assistência Social, } \\
\text { Conselho Municipal de Cultura, } \\
\text { Conselho Municipal da Mulher, } \\
\text { Conselho Municipal do Idoso, } \\
\text { Conselho Municipal dos Direitos da } \\
\text { Pessoa com Deficiência, Conselho } \\
\text { Municipal da Juventude, Conselho } \\
\text { da Cidade, Conselho Municipal } \\
\text { Antidrogas, Conselho Municipal de } \\
\text { Segurança Alimentar e Nutricional }\end{array}$ & 1997 a 2010 \\
\hline Conferências setoriais & $\begin{array}{l}\text { Participação e representação como } \\
\text { delegados nas conferências de políticas } \\
\text { públicas }\end{array}$ & 1997 a 2010 \\
\hline
\end{tabular}




\begin{tabular}{|c|l|c|}
\hline Convênios com Executivo & $\begin{array}{l}\text { Coordenação da AMO (Assembleia } \\
\text { Municipal do Orçamento) que estru- } \\
\text { tura as discussões e deliberações do } \\
\text { orçamento participativo nos bairros e } \\
\text { regiões da cidade }\end{array}$ & 2011 a 2010 \\
\cline { 2 - 4 } & $\begin{array}{l}\text { Coordenação da participação po- } \\
\text { pular no Plano Diretor Municipal } \\
\text { Participativo (PDMP), por meio da } \\
\text { instalação de instâncias de discussão } \\
\text { com a população das regiões da cidade }\end{array}$ & 2008 \\
\hline & $\begin{array}{l}\text { Realização do I Festival Popular de } \\
\text { Cultura da Serra "Lei Chico Prego" }\end{array}$ & 2007 \\
\hline Convênio com Legislativo & $\begin{array}{l}\text { Realização de curso de capacitação } \\
\text { de lideranças populares "Projeto } \\
\text { Formando Líderes" }\end{array}$ & 2005 a 2007 \\
\hline Earantia de infraestrutura física para o \\
funcionamento da Federação
\end{tabular}

Fonte: Pesquisa Movimentos sociais e instituições participativas (2012).

O engajamento do movimento popular nos encaixes construídos assumiu centralidade em suas atividades, com efeitos sobre seu padrão organizacional. É neste contexto que ocorre, na Fams, um processo de complexificação organizacional caracterizado por especialização funcional, profissionalização, financiamento público e privado e formalização das estratégias de ação (Carlos, 2015b, 2012). Do ponto de vista do funcionamento da Fams, a complexificação organizacional tanto é indício do investimento dessa nos encaixes quanto corresponde a condições sob as quais os encaixes operam, dado que se converte em competências ou capacidades sociais. Sua especialização funcional consiste na maior especificação 
dos órgãos, mediante a criação de novos organismos e de mais precisão nas atribuições dos mesmos. A especialização das funções visa ajustar sua estrutura funcional às múltiplas possibilidades de participação e representação na elaboração e implementação de políticas públicas, ampliando sua atuação em setores que favorecem maior conhecimento sobre o funcionamento da máquina pública e o modus operandi do Estado. Esse amoldamento da estrutura funcional do movimento à funcionalidade do Estado conduz os atores coletivos à discussão de políticas públicas de modo mais enfático, algo notadamente caro tratando-se de associações tradicionalmente afeitas a reivindicações pontuais e concretas.

A profissionalização é caracterizada pela integração de profissionais temporários (remunerados ou voluntários) no interior da organização do movimento, voltados ao suporte técnico ou jurídico nas áreas de secretaria, comunicação, contabilidade e advocacia. Nesse processo de complexificação organizacional, o financiamento das atividades foi incrementado por recursos dos setores público e privado, mediante convênios e termos de parceria, conforme destacado. Essa diversificação das fontes de autossustentação financeira da Fams possui consequências para a sua estrutura funcional, na medida em que, demandando maior aquisição de conhecimentos técnicos especializados, aumenta a necessidade de assessoria de profissionais e de especialização temática.

Acompanha essa configuração na Fams o acréscimo de novos objetivos e as mudanças nas estratégias de ação. As transformações nos objetivos significaram a incorporação de novas finalidades ao objetivo fundacional, como a elaboração e gestão de políticas públicas, a implementação de programas e projetos governamentais e o estabelecimento de convênios, colaborações e parcerias com órgãos públicos, setores privados ou da sociedade civil. Ao passo que as mudanças nos repertórios correspondem à "formalização das estratégias de ação", caracterizada pela preponderância de repertórios formais, rotinizados e previsíveis em prejuízo dos protestos 
públicos. Na Fams, esse padrão organizacional complexo e formalizado é combinado a uma dinâmica de mobilização, dado pelo incremento no associativismo civil e pela pluralização das esferas de participação. Nesses termos, a complexificação organizacional não corresponde à burocratização e à desmobilização do movimento, na medida em que o formato inovador das IPs gera incentivos à expansão do associativismo e à emergência de novas formas de mobilização das coletividades (Carlos, 2015b, 2012). ${ }^{22}$

O processo de transformação no padrão organizacional do movimento, de diversificação e modernização funcional, compreende diferentes estratégias, habilidades e competências dos atores societários para ampliar sua influência na agenda pública por meio da construção de domínios de agência. Gurza Lavalle e Bueno (2011) identificaram na ecologia organizacional da sociedade civil, em São Paulo e na Cidade do México, um padrão similar de distintas competências dos atores da sociedade civil para influenciar as políticas públicas que nomeiam de "diferenciação funcional" - uma estratégia de fortalecimento institucional de êxito no universo das organizações sociais.

Essas mudanças organizacionais na ação coletiva são extensivas às transformações na relação sociedade-Estado, conformando novos padrões de interação socioestatal (Carlos, 2015b, 2017, 2012). Na Fams, o estabelecimento de nova concepção de relação com o Estado ocorreu em prejuízo das categorias de antagonismo e oposição, outrora preponderantes, e da ascensão das de cooperação, parceria, proximidade e diálogo. Nesse caso, o padrão de interação cooperativo tornou-se emergente, caracterizado pelo estabelecimento de relações de colaboração na elaboração de políticas públicas e na implementação de programas do governo. Com

22 Para maiores informações sobre os efeitos do engajamento institucional em instituições participativas e agências governamentais sobre o padrão organizacional da Fams, vide: Carlos (2015b, 2012), Capítulos 3, 5 e 8. Para uma síntese dessa discussão, vide: Carlos (2015a). 
efeito, os encaixes institucionais e as interações socioestatais se constituem mutuamente, associando dada configuração de acessos ao Estado a determinado padrão de relação.

Cabe assinalar que a cooperação compreende "a relação entre duas partes baseada na concordância quanto aos fins de uma dada ação, que envolve uma colaboração ativa com o objetivo de atingir cada finalidade" (Giugni e Passy, 1998, p. 84). A cooperação é definida a partir do nível pragmático da concordância, isto é, quando a relação de colaboração se converte em ações concretas, podendo ser de três formas: consulta, quando os atores não institucionais colaboram com informações relevantes à tomada de decisões; integração, quando os atores agem na implementação de decisões mediante a atuação em comitês, grupos de trabalho ou agências governamentais; e delegação, quando o Estado transfere a responsabilidade para o movimento no nível operacional. Desse modo, a cooperação se estabelece no plano da solução de problemas sociais e da contribuição com o Estado na elaboração, implementação ou execução de políticas públicas, em que movimentos sociais colaboram com o seu conhecimento e informação sobre uma política pública. No entanto, é preciso advertir que nas relações de cooperação (i) a concordância quanto aos fins da ação raramente é completa, dada a assimetria de poder e de interesses entre os atores societários e os estatais; (ii) a cooperação com o Estado não é extensiva ao nível do consenso quanto às políticas governamentais; (iii) os movimentos são ambivalentes e utilizam uma estratégia de combinação de conflito e cooperação (Giugni e Passy, 1998).

Neste contexto de construção de encaixes no Estado o movimento deixou de ser caracterizado como ator e âmbito para a confrontação política e passou a se perceber como instância para o diálogo e a colaboração com aqueles com os quais se pode alcançar resultados para suas ações, ainda que a cooperação não signifique a eliminação do conflito. Para o movimento popular, a construção de 
relações de cooperação com o Estado favorece o resultado de suas ações porque com acesso aos órgãos públicos e a espaços institucionais os atores societários alcançam o reconhecimento da sua legitimidade. Em outros termos, relações de proximidade e cooperação com os governos são relevantes ao atendimento das reivindicações do movimento, ao estabelecimento do diálogo e da proposição, à representação e à participação nas instituições participativas, à discussão, à fiscalização, ao acompanhamento de políticas públicas e à gestão de programas e convênios governamentais. Em suma, as interações colaborativas têm como consequências o atendimento a demandas históricas do movimento e a sua influência política na agenda pública.

Em face do conjunto de encaixes construídos, das capacidades organizacionais e das interações socioestatais cooperativas, a percepção do movimento de influência na agenda pública remete ao seu domínio de agência. As capacidades de agência do ator consistem seja na legitimidade de agir, na autorização e no reconhecimento pelo Estado, seja na institucionalização de demandas históricas, especialmente de canais participativos de mediação da relação com a esfera estatal e o acesso aos órgãos públicos. Particularmente, os encaixes institucionais conferem à Fams a influência política e o domínio de agência para coordenar processos de democracia participativa (conduzir a instalação anual do OP por meio da AMO, dirigir o órgão municipal NAOP, implementar instrumentos de participação no PPA e no PDU), sendo reconhecida sua expertise nesse campo e conferida a autorização do governo para agir em seu nome. A articulação entre os encaixes produz o domínio de agência que qualifica as capacidades de ação da Fams, concernente ao desenho e implementação de instituições participativas em prol de políticas urbanas e sociais, cujas expertises e papéis específicos são reconhecidos. À configuração desse domínio de agência soma-se, além dos encaixes institucionais, o padrão de complexificação organizacional e o padrão de interação coope- 
rativo. Encaixes, capacidades organizacionais e cooperação assim se coadunam na construção de domínios de agência.

Do ponto de vista das consequências mais gerais desse processo de institucionalização para o movimento, por outro lado, os ativistas reconhecem os riscos à sua autonomia: risco de dependência e submissão, de atrelamento e cooptação; de perda da autonomia e de distanciamento da base social; de impedimento de ações contrárias e críticas ao governo; de vinculação da imagem do movimento com a do governo; e da perda da capacidade de discussão e proposição. Isso porque o exacerbamento da cooperação e de vínculos institucionais com o Estado pode reduzir sua potencial capacidade de pressão e influência, favorecendo a dependência dos atores coletivos.

Na Fams, a relação de colaboração com o governo nos encaixes arquitetados tem obstado um posicionamento crítico e independente dos atores coletivos, ainda que os ativistas associem esse padrão ao êxito nos resultados das suas ações e ao acesso à esfera política. Com efeito, dependência, submissão e atrelamento são as categorias que traduzem ali uma autonomia frágil, configurando, assim, um padrão de interação cooperativo e dependente. Vale ressaltar que dependência é aqui entendida como a dificuldade de sustentar posições de modo independente dos interesses estatais e da agenda política governamental, mas não se confunde com cooptação, isto é, com a mudança de objetivos dos ativistas.

A heterogeneidade da Fams, revelada nas percepções de "ganhos" e "perdas" das interações cooperativas via encaixes institucionais e domínio de agência, desnuda um movimento potencialmente em conflito e sujeito a reposicionamentos frente à institucionalidade política. Contudo, as disparidades internas têm sido contidas pela regra de composição de chapas introduzida na última década, ${ }^{23}$ a qual estabelece a proporcionalidade na

23 A composição de chapa foi instituída pelo Estatuto Social da Fams de 2003 (Art. 79). 
distribuição de cargos da diretoria segundo o número de votos obtidos no congresso pelas chapas concorrentes, o que tende a suprimir a oposição e a fortalecer a política de alianças internas mediadas, em geral, por acordos com partidos políticos da base aliada do governo. Em decorrência da relevância política que assume um movimento social, a não formação de alianças pode gerar facciosismo entre os grupos participantes, o acirramento de disputas e o enfraquecimento da unidade necessária à implementação do programa de lutas gerais. Por outro lado, a formação de aliança puramente instrumental, ou seja, descolada de afinidades ideológicas, pode acarretar a descaracterização do movimento e abrandar os vínculos entre as lideranças e suas bases.

\section{Conclusão}

Nos processos de institucionalização no Brasil pós-transição assume proeminência a construção histórica de encaixes institucionais e domínios de agência. $\mathrm{Na}$ abordagem deste estudo, a ênfase nos processos temporais e no caráter mutuamente constitutivo das relações entre Estado e sociedade atenta para as configurações dessas esferas como condicionantes da construção de acessos institucionais e de influência política.

Nesse bojo, este capítulo buscou demonstrar que os encaixes institucionais no Estado são historicamente construídos mediante processos de interação com instituições na fundação do movimento e de aprendizado institucional, bem como de permeabilidade do Estado aos atores societários e às suas demandas. Esses remetem aos mecanismos de construção de encaixes e domínio de agência. Por um lado, a gênese relacional do movimento, expressa nas relações pregressas com incubadoras institucionais, em particular segmentos da Igreja católica e partidos políticos de esquerda, sobretudo o PT, afetam positivamente a capacidade dos atores sociais a arquitetar encaixes no Estado, mediante processos reificados de interação 
em torno da produção de políticas. A relação com instituições na fundação do movimento favorece o aprendizado institucional e o reconhecimento dos atores estatais como interlocutores válidos, na medida em que funcionam como incubadoras institucionais. As conexões do movimento social com partidos políticos e grupos religiosos na sua fundação são intermediadas pela multifiliação dos ativistas que se engajam e entrecruzam entre movimentos e instituições. Por outro lado, a permeabilidade do Estado ao setor de política demandado pelo movimento amplia as possibilidades de encaixe e interferência nas decisões políticas. Conforme evidenciado, a porosidade estatal é potencializada quando a relação entre atores institucionais e societários é mediada por coalizões partidárias e eleitorais, conclamando a interdependência entre movimentos, partidos e eleições na construção de encaixes no Estado.

Os encaixes forjados pela Fams são extensivos às transformações organizacionais e na relação sociedade-Estado, com destaque aos processos de complexificação e modernização organizacional do movimento, por um lado, e a emergência do padrão de interação socioestatal cooperativo, por outro. Estas novas formas organizacionais, repertórios, estratégias e identidades dos atores societários compreendem habilidades e competências de fortalecimento institucional com vistas à influência na agenda pública. Particularmente, o padrão de interação cooperativo estabeleceu nova linguagem de relação com o Estado voltada à elaboração e implementação de políticas públicas. Nesse aspecto, encaixes e interações socioestatais se constituem mutuamente com vistas à influência no processo decisório, podendo se converter em domínio de agência.

Especialmente, os encaixes institucionais e domínio de agência da Fams consistem na sua capacidade de interferência em processos de participação da sociedade civil na definição de políticas públicas, em diversos setores, seja no orçamento municipal seja nas políticas sociais e urbanas. A influência desse ator é percebida 
mediante o atendimento de suas demandas históricas a exemplo da institucionalização de canais de participação e, por intermédio desses, de suas demandas em termos de políticas sociais e de infraestrutura urbana, mas também do acesso aos órgãos governamentais por meio da ocupação de cargos públicos e da implementação de programas do governo.

Por fim, resta mencionar que a influência política e domínio de agência da Fams veio acompanhada de fragilização da sua autonomia na relação com o Estado. $\mathrm{O}$ movimento popular da Serra parece diante de um cenário de trade-off quando é preciso para obter influência política, fragilizar a autonomia. A institucionalização dos encaixes construídos pela Fams ao longo do tempo conduziu o movimento à interferência na agenda pública e nas políticas governamentais, não obstante às custas de maior independência na definição dos procedimentos e objetivos da ação. Especificamente nesse caso, uma dimensão parece operar em detrimento da outra, afinal, "a relação entre movimentos sociais e sistema político é permeada por uma tensão intrínseca entre os princípios da autonomia e a da eficácia política" (Tatagiba, 2010, p.67). Averiguar sob quais condições a influência e a autonomia podem ser combinadas no domínio de agência é questão para estudos futuros desta agenda de pesquisa.

\section{REFERÊNCIAS}

ABERS, Rebecca; KECK, Margaret. Practical Authority: Agency and Institutional Change in Brazilian Water Politics. Oxford: Oxford University Press, 2013.

ABERS, Rebecca; VON BÜLOW, Marisa. Movimentos sociais na teoria e na prática: como estudar o ativismo através da fronteira entre Estado e sociedade? Sociologias, 2011, n. 28, pp. 52-84. 
ABERS, Rebecca; SERAFIM, Liza; TATAGIBA, Luciana. Repertórios de interação Estado-sociedade em um Estado heterogêneo: a experiência na era Lula. Dados, 2014, v. 57, n. 2, pp. 325-357. Disponível em: <http://dx.doi. org/10.1590/0011-5258201411>.

CARDOSO, Ruth. Os movimentos populares no contexto da consolidação da democracia. In: O'Donnel, Guillermo; Reis, Fabio W. (Ed.) A democracia no Brasil: dilemas eperspectivas. São Paulo: Vértice, 1988.

CARLOS, Euzeneia. Movimentos sociais e instituições participativas: efeitos organizacionais, relacionais e discursivos. Tese (Doutorado em Ciência Política) Universidade de São Paulo, São Paulo, 2012.

CARLOS, Euzeneia. Controle social e politica redistributiva no orçamento participativo. 2. ed. Vitória: EdUfes, 2015.

CARLOS, Euzeneia. Movimentos sociais e instituições participativas: efeitos do engajamento institucional nos padrões de ação coletiva. Revista Brasileira de Ciências Sociais, 2015a, v. 30, n. 88, pp. 83-99.

CARLOS, Euzeneia. Movimentos sociais e instituições participativas: efeitos do engajamento institucional no contexto pós-transição. Belo Horizonte: Fino Traço, 2015 b.

CARLOS, Euzeneia. Movimentos sociais e sistema político nas teorias dos movimentos sociais. Interseçôes, Rio de Janeiro, 2015c, v. 17, n. 1, pp. 54-78.

CARLOS, Euzeneia. Cooperação e conflito na relação movimentos sociais e Estado. Politica e Sociedade, 2017, v. 16, n. 35, pp. 321-350.

CARLOS, Euzeneia; DOWBOR, Monika; ALBUQUERQUE, Maria do Carmo. Movimentos sociais e seus efeitos nas políticas públicas: balanço do debate e proposições analíticas. Civitas, 2017, v. 17, n. 2, pp. 360-378.

DAGNINO, Evelina. Os movimentos sociais e a emergência de uma nova noção de cidadania. In: Dagnino, Evelina. Anos 90: política e sociedade no Brasil. São Paulo: Brasiliense, 1994, pp. 103-115.

DAGNINO, Evelina (Ed.). Sociedade civil e espaços públicos no Brasil. São Paulo: Paz e Terra, 2002.

DOIMO, Ana M. A vez e a voz do popular: movimentos sociais e participação politica no Brasilpós-70. Rio de Janeiro: Relume-Dumaré/Anpocs, 1995. 
DOWBOR, Monika. A arte da institucionalização: estratégias de mobilização dos sanitaristas (1974-2006). Tese (Doutorado em Ciência Política) Universidade de São Paulo, São Paulo, 2012. Disponível em: <http://dx.doi. org/10.11606/T.8.2012.tde-06032013-111003>.

GIUGNI, Marco; PASSY, Florence. Contentious politics in complex societies: new social movements between conflict and cooperation. In: Giugni, Marco; McAdam, Doug; Tilly, Charles (Ed.). From Contention to Democracy. Lanham, MA: Rowman and Littlefield, 1998.

GOHN, Maria da Glória. Luta pela moradia popular em São Paulo: movimentos de moradia, 1975/85. São Paulo: Anpocs/Vértice, 1988, pp. 311-333. (Ciências Sociais Hoje)

GOLDSTONE, Jack. Bridging institucionalized and noninstitucionalized politics. In: Goldstone, Jack E. (Ed.) States, Parties, and Social Movements. Cambridge: Cambridge University Press, 2003.

GURZA LAVALLE, Adrian; BUENO, Natalia. Waves of Change Within Civil Society in Latin America: Mexico City and São Paulo. Politics and Society, 2011, v. 39, n. 3, pp. 415-450.

GURZA LAVALLE, Adrian; CARLOS, Euzeneia; DOWBOR, Monika; SZWAKO, José (2017), Movimentos sociais, institucionalização e dominios de agência. São Paulo: Centro de Estudos da Metrópole (CEM), 2017, n. 19, pp. 3-40. (Série Textos para Discussão CEM) Disponível em: <http://web.fflch. usp.br/centrodametropole/upload/aaa/2123-wp19.2017.vfmesmo.pdf>.

GURZA LAVALLE, Adrian; HOUTZAGER, Peter; CASTELLO, Graziela. La construcción política de las sociedades civiles. In: Gurza Lavalle, Adrian (Ed.). El horizonte de la política: Brasily la agenda contemporánea de investigación en el debate internacional. México: Ciesas, 2011.

GURZA LAVALLE, Adrian; SZWAKO, José. Sociedade civil, Estado e autonomia: argumentos, contra-argumentos e avanços no debate. Opinião Pública, 2015 , v. 21, n. 1, pp. 157-187.

HANAGAN, Michael. Social Movements, Incorporation, Disengagement, and Opportunities: A Long View. In: Giugni, Marco; McAdam, Doug; Tilly, Charles (Ed.). From Contention to Democracy. Lanham, MA: Rowman and Littlefield, 1998. 
HOUTZAGER, Peter. Os últimos cidadãos: conflito e modernização no Brasil rural. São Paulo: Globo, 2004.

KRIESI, Hans P. La estructura organizacional de los nuevos movimientos sociales en su contexto político. In: McAdam, Doug; McCarthy, John; Zald, Mayer (Ed.). Movimientos sociales: perspectivas comparadas. Madrid: Istmo, 1999, pp. 221-261.

MARQUES, Eduardo C. Redes sociais e instituições na construção do Estado e da sua permeabilidade. Revista Brasileira de Ciências Sociais, 1999, v. 14, n. 41, pp. 45-67.

MARQUES, Eduardo C. Redes sociais e poder no Estado brasileiro: aprendizados a partir de políticas urbanas. Revista Brasileira de Ciências Sociais, 2006, v. 21, n. 60, pp.15-41.

MCADAM, Doug; TARROW, Sidney; TILLY, Charles. Dynamics of Contention. Cambridge: Cambridge University Press, 2001.

MCCARTHY, John; ZALD, Mayer. The Trends of Social Movements in America: Professionalization and Resource Mobilization. Morristown, NJ: General Learning Press, 1973.

MEYER, David S.; TARROW, Sidney (Ed.). The Social Movement Society: Contentions Politics for a New Century. Lanham, MA: Rowman and Littlefield, 1998.

MISCHE, Ann. Cross-talk in Movements: Reconceiving the Culture-Network Link. In: Diani, Mario; McAdam, Doug (Ed.). Social Movements and Networks: Relational Approaches to Collective Action. Oxford: Oxford University Press, 2003, pp. 258-280.

MISCHE, Ann. Partisan Publics: Communication and Contention Across Brazilian Youth Activist Networks. Princeton, NJ: Princeton University Press, 2008.

PIVEN, Frances F.; CLOWARD, Richard. Poor People's Movements: Why They Succeed, How They Fail. New York: Vintage Books, 1979.

SADER, Eder. Quando novos personagens entram em cena: experiências, falas e lutas dos trabalhadores da Grande São Paulo (1970-80). São Paulo: Paz e Terra, 1980. 
SERPA, Ana Maria Petronetto. 2uando o povo institui seus espaços politicos e os transforma em espaços pedagógicos: um estudo da dimensão educativa dos movimentos populares da Serra. Dissertação (Mestrado em Educação) Universidade Federal do Espírito Santo, Vitória, 1990.

SILVA, Marcelo K.; OLIVEIRA, Gerson. A face oculta(da) dos movimentos sociais: trânsito institucional e intersecção Estado-Movimento: uma análise do Movimento de Economia Solidária no Rio Grande do Sul. Sociologias, 2011, ano 13, n. 28, pp. 86-124.

SKOCPOL, Theda. Protecting Soldiers and Mothers: The Political Origins of Social Policy in the United States. Cambridge, MA: Harvard University Press, 1992.

TARROW, Sidney. El poder en movimiento: los movimientos sociales, la acción colectiva y la política. Madri: Alianza, 1997.

TATAGIBA, Luciana. Desafios da relação entre movimentos sociais e instituições políticas: o caso do movimento de moradia da cidade de São Paulo: primeiras reflexões. Colombia Internacional, 2010, v. 71, pp. 63-83.

TATAGIBA, Luciana; TEIXEIRA, Ana C. Efeitos combinados dos movimentos de moradia sobre os programas habitacionais autogestionários. Revista de Sociologia e Politica, 2016, v. 24, n. 58, pp. 85-102.

TELLES, Vera da S. Sociedade civil e a construção de espaços públicos. In: Dagnino, Evelina (Ed.). Anos 90: política e sociedade no Brasil. São Paulo: Brasiliense, 1994, pp. 91-102.

\section{Documentos Citados}

FAMS. Federação das Associações de Moradores da Serra, ES. Reunião de delegados, da Federação das Associações de Moradores do Município da Serra, 17 jun. 1981, doc. 7, 1981.

FAMS. Federação das Associações de Moradores da Serra, ES. Livro de atas, de reuniões do período 14 mar. 1982 a 06 dez. 1983, doc. 9, 1983.

FAMS. Federação das Associações de Moradores da Serra, ES. I Congresso dos Movimentos Populares da Serra, Teses apresentadas, doc. 24, 1986. 
FAMS. Federação das Associações de Moradores da Serra, ES. Estatuto social, doc. 4, 2003.

FAMS. Federação das Associações de Moradores da Serra, ES. Jornal da FAMS, Ano IV, n. 22, p. 7, doc. 135, 2009. 



\author{
Capítulo 4 \\ ANALISANDO IMPACTOS DO MOVIMENTO \\ SOCIAL NA CONSTRUÇÃO DA POLÍTICA \\ SOCIOEDUCATIVA: COALIZÕES \\ DE DEFESA E ENCAIXES
}

Maria do Carmo Albuquerque

\title{
1. Introdução
}

Após serem louvados como novos atores que protagonizaram a cena política latino-americana nas transições pós-ditaduras, entre as décadas de 1970 e 1990, os movimentos sociais foram criticados por suas relações com o Estado e partidos políticos, apontadas como causas de perda de vigor na sua ação, de acomodação e cooptação (Silva e Oliveira, 2011). Foi difícil analisar essas relações a partir de uma perspectiva centrada na sociedade civil, que tinha seu foco principal em valorizar o caráter extrainstitucional e disruptivo dos movimentos, capazes de escapar dos formatos burocratizados dos atores que tinham lugar definido e institucionalizado em disputas na esfera política, como partidos e sindicatos.

No entanto, no processo de construção democrática que se seguiu, especialmente no Brasil (Abers e von Bülow, 2011; Albuquerque, 2015) os movimentos assumiram um papel destacado na conquista de novas políticas públicas de garantia de direitos. É o que vemos a partir do processo Constituinte, com a reivindicação, elaboração e implementação de novas políticas de direitos nas áreas da saúde (definidas pelo SUS), de direitos da criança e 
adolescente (ECA), assistência social (SUAS), moradia popular (Estatuto das Cidades), segurança alimentar, meio ambiente, entre outras (Albuquerque, 2006).

Nesses processos participativos os movimentos desenvolveram novas formas de organização e de ação que muitas vezes foram consideradas como "desvios", com base nas expectativas teóricas anteriores. A relação institucionalizada com o Estado foi vista como causa de burocratização da ação dos movimentos, de afastamento de seus objetivos radicalmente transformadores, de sua cooptação aos objetivos e formas de ação limitados pelas normativas estatais e aos diversos interesses presentes na sociedade política.

Tornou-se então necessário entender qual o papel dos movimentos sociais quando participam da política institucionalizada. Para tal, uma parcela significativa da literatura atual vem-se perguntando se "os movimentos importam", quando e como; buscando analisar seus resultados, impactos, efeitos ou efetividade na incidência sobre as políticas públicas pelas quais vêm lutando. ${ }^{1}$

No Brasil, essa nova literatura enfatiza "uma abordagem relacional no estudo dos movimentos sociais" e, ao invés de pensar a interação com a política institucional como um "desvio", defeito ou ameaça à autenticidade do movimento, passa a ver essa interação como constitutiva de sua ação (Silva e Oliveira, 2011, p. 88). Essa perspectiva considera a relação entre movimento e Estado como de mútua constituição (Dagnino, 2011, p. 124). Para tal articula teorias que, por um lado, focam o movimento como um ator envolvido em um processo político, que interage e desafia continuamente a sociedade política - Estado e partidos - e, por outro, analisa os processos

\footnotetext{
Esta perspectiva vem sendo recentemente explorada por autores brasileiros como Abers, Serafim e Tatagiba (2014), Abers e von Bülow (2011), Carlos (2012), Sherrer-Warren e Lüchmann (2011), Dowbor (2012), Silva (2011), Carlos, Dowbor e Albuquerque, (2016), entre outros, que explicitam a importância do estudo sobre a interação sócio-estatal dos movimentos sociais. $\mathrm{O}$ presente volume apresenta explicitamente esta questão na Introdução e nos seus diversos capítulos.
} 
de construção das políticas públicas, as teorias da mudança institucional, especialmente na vertente neo-institucionalista, por sua ênfase na mútua influência entre as instituições políticas e a diversidade de atores socioeconômicos que incidem nas políticas.

Referência destacada na investigação sobre se e quando os movimentos importam é Edwin Amenta (2006 e 2010) que investiga "as consequências políticas dos movimentos sociais", especialmente aqueles que são orientados para políticas públicas ou para conquistas no Estado, questionando as perspectivas que destacam apenas condições econômicas e "burocratas clarividentes" como os principais determinantes das políticas públicas.

No campo empírico analisamos neste capítulo as consequências políticas do movimento pelos direitos da criança e adolescente (movimento DCA), constituído no Brasil desde as lutas no processo Constituinte, voltado para a afirmação do paradigma garantista dos direitos da infância, focalizando aqui a sua incidência na construção e implementação da política socioeducativa, aquela que é voltada ao adolescente em conflito com a lei, ${ }^{2}$ no período pós-transição democrática. $^{3}$

Esse movimento social lutou pelo fim do chamado paradigma menorista, caracterizado pela discriminação aos menores ditos em situação irregular - situação de abandono, carência, marginalidade ou delinquência, e pela efetivação do paradigma garantista, também

2 Dentro da política de direitos da criança e adolescente, definida principalmente pelos artigos 227 e 228 da Constituição Federal e pelo ECA (Estatuto da Criança e Adolescente), a política socioeducativa é a que trata do atendimento e dos direitos do adolescente em conflito com a lei, definida pela Lei n.12.594, de 2012 (Lei do Sinase - Sistema Nacional de Atendimento Socioeducativo). Essa política trata das medidas judiciais impostas ao adolescente infrator, que podem ser privativas de liberdade, ou aplicadas em meio aberto. $\mathrm{O}$ artigo parte das dimensões nacional e estadual dessa política, mas se detém no seu âmbito municipal.

3 Esta análise está sendo aprofundada pela pesquisa "Efetividade dos movimentos sociais nas políticas públicas em perspectiva comparada”, realizada com auxílio do CNPq e da Fundação de Amparo à Pesquisa e Inovação do Espírito Santo (Fapes). A pesquisa tem uma primeira publicação (Carlos, Dowbor e Albuquerque, 2017). 
conhecido como Doutrina da Proteção Integral da criança e do adolescente, consolidada na Convenção da ONU pelos Direitos da Infância (CDI), em 1989.

Uma intensa interação entre esse movimento e o Estado produziu inovações institucionais que traduzem o novo paradigma na Constituição de 1988 e no ECA - Estatuto da Criança e do Adolescente (Albuquerque, 2014; 2015), constituindo um novo paradigma na política pública de direitos para a criança e o adolescente (política DCA).

Essas inovações, no entanto, tardaram muito e ainda tardam a ser incorporadas à política que trata dos direitos do adolescente em conflito com a lei, a chamada política socioeducativa. Só em 2006 surge a primeira normativa garantista sobre esta política - o Sistema Nacional de Atendimento Socioeducativo (Sinase), tornado lei em 2012, e que nos últimos anos vem se traduzindo em Planos Decenais de atendimento socioeducativo nos três níveis da federação. Analisamos aqui três ciclos de mobilização e de incidência do movimento nas mudanças institucionais que apontam uma nova perspectiva - garantista - na política socioeducativa.

Para tal examinamos a pertinência do uso de algumas categorias analíticas para a compreensão da ação do movimento no contexto de construção democrática pós-transição. Analisamos especialmente a formação de coalizões de defesa do paradigma garantista envolvendo esses atores e a construção de encaixes socioestatais entre eles. ${ }^{4}$

\section{Um instrumental analítico para pensar a incidência nas políticas públicas}

O período pós-transição no Brasil traz uma inflexão na ação dos movimentos sociais que se engajam em lutas pela conquista e

4 Não chegamos a tratar da formação de configurações de encaixes socioestatais e de domínios de agência como grande parte da perspectiva focada neste livro. 
garantia de direitos, por meio de novas políticas públicas de garantia desses direitos, por meio de intensa interação socioestatal.

Anteriormente saudados por sua capacidade disruptiva e de confronto, por sua espontaneidade e autonomia, definidas por uma suposta recusa do Estado e da institucionalidade, os novos movimentos sociais geraram uma certa expectativa de que participariam de "um verdadeiro cerco ao Estado" a partir de uma sociedade generalizadamente organizada que dispensaria "a mediação dos políticos" (Garcia, 1992). Houve profunda decepção de estudiosos quando essa mediação não foi dispensada, mas os movimentos participaram do jogo democrático, progressivamente restabelecido, por meio dos partidos políticos e da "interação com o sistema político administrativo” (Somarriba, 1996, p. 58). A perplexidade com a participação dos movimentos na esfera político-institucional levou a literatura dos anos 1990, de forma bastante ampla, a um balanço crítico sobre autonomia em registro negativo, como apontam Silva (2011) e Gurza Lavalle e Szwako (2015, p. 157), autores que enfatizam os ganhos analíticos de uma perspectiva "centrada nas interações socioestatais e de uma compreensão relacional de autonomia tanto no plano da prática dos atores quanto no plano da teoria".

Ao invés de ver movimentos despreparados para ultrapassar a lógica de relações horizontais e que seriam tragados pela lógica assimétrica da política institucional, tornou-se então preciso vê-los enfrentando estes dilemas, e buscar entender como o fazem, como se envolvem em processos políticos menos horizontais e mais contraditórios. Foi nessa perspectiva que buscamos a literatura que avalia a incidência política dos movimentos, seus resultados nas mudanças em políticas públicas.

Contribuindo para entender os fatores que possibilitam a interação com o mundo da política, Amenta et al. (2010, p. 141) analisam as "condições em que os movimentos são importantes" na incidência política. Esses e outros autores formulam modelos 
de análise dos efeitos políticos do movimento (Carlos, Dowbor e Albuquerque, 2016; Tatagiba e Teixeira, 2016), destacando fatores ligados aos próprios movimentos e dimensões ligadas ao Estado e outros atores político-estatais com os quais interage o movimento. Para tal se destaca a literatura neoinstitucionalista, especialmente em seu registro histórico.

As perspectivas neo-institucionalistas analisam o papel das instituições e as vêm como atores estatais, que interagem com atores econômicos e societais na origem e formulação das políticas públicas. ${ }^{5}$ Para entender a incidência dos movimentos sociais nas políticas públicas o neo-institucionalismo histórico é particularmente fecundo, na medida em que coloca a ênfase nos processos, analisando a "sequência de trajetos e decisões que, no longo prazo, circunscrevem as possibilidades e rumos de desenvolvimento institucional" (Szwako, 2013, p. 6). As instituições não são apenas arena, contexto ou cenário dessas mudanças, mas reguladoras dos conflitos e disputas políticas que oferecem constrangimentos à ação dos atores nelas envolvidos. Enfatiza assim os processos de construção das preferências e interesses dos atores, sua identidade, posições e consciência políticas:

Nessa chave trata-se de entender a 'construção política de interesses' [...], isto é entender em que medida e de que forma arranjos institucionais influenciam a construção dos interesses, ideias, posições, identidades e mesmo a consciência dos atores [...] na constituição de suas preferências (Szwako, 2013, p. 7).

Além da redescoberta de que "as instituições importam", vemos assim que as ideias também importam na mudança institucional (Tomazini e Lukic, 2013). É um conjunto de ideias e crenças

5 A escolha do neo-institucionalismo face às abordagens do pluralismo, corporativismo e neocorporativismo é amplamente analisada no capítulo introdutório do presente volume. 
denominado paradigma garantista o que organiza e constrói politicamente os interesses, posições e ações do movimento DCA, que emerge nas lutas pela Constituição de 1988 e pelo ECA, em 1990.

Crenças em comum são importantes, conforme Sabatier e Weible (2007), para a formação de coalizões que articulam atores distintos em torno de propostas para uma dada política. Os autores distinguem, entre os tipos de crenças que dão origem a coalizões, aquelas mais centrais e profundas, ligadas a princípios gerais (crenças core) e, num segundo nível, as crenças ligadas a uma política setorial, "que projetam uma imagem de como o subsistema de política deveria ser" e que fornecem “a visão que orienta o comportamento estratégico da coalizão, e ajudam a unir aliados e dividir adversários" (Sabatier e Weible, 2007, p. 195). Para além de compartilhar crenças, esses autores apontam que, para a formação das coalizões, é preciso que os atores comecem a coordenar suas estratégias de ação, a trabalhar juntos para atingir objetivos semelhantes. Esta noção de coalizão de atores que atuam conjuntamente na defesa política de um ideário guarda semelhança com a ideia de compartilhamento de "projeto político" desenvolvida por Dagnino (2002; 2004, p. 144) para apontar o compartilhamento de crenças e posições políticas entre atores da sociedade civil e política que "orientam a ação política" dos diferentes sujeitos.

O conceito de coalizão é mais restrito do que o conceito formulado por Dagnino, visto que este se refere a um "conjuntos de crenças, interesses, concepções de mundo, representações do que deve ser a vida em sociedade, que orientam a ação política dos diferentes sujeitos" (2004, p. 144). Sabatier e Weible, embora também se refiram a crenças mais "centrais e profundas", enfocam aquelas ligadas ao formato de uma política pública setorial e ainda os comportamentos concretos de aliados e adversários que organizam suas estratégias em torno a lutas concretas. Embora mais restrito, é um conceito que pode ser operacionalizado de forma bastante útil, no caso das lutas por transformações institucionais que estamos analisando. 
No caso das políticas de direitos da criança e adolescente, veremos que um conjunto de atores, tanto societais quanto estatais, ainda que não coesos em torno de um amplo projeto político, compartilha crenças que orientam seu comportamento e suas estratégias políticas, constituindo alianças ou coalizões em torno do chamado paradigma garantista. Essas coalizões favorecem a construção de encaixes, potencializando novos pontos de acesso das demandas civis ao Estado.

A noção de encaixe entre Estado e sociedade é desenvolvida por Skocpol em suas obras de 1985 a 1995. A autora analisa o lugar de construção de significados, o locus da construção e tomada de consciência dos objetivos políticos dos atores sociais e destaca como tais os "pontos de encaixe" entre Estado e sociedade:

Os significados da vida pública e as formas através das quais os grupos coletivos tornam-se conscientes dos objetivos políticos e trabalham para atingi-los surgem não da sociedade por si só, mas nos pontos de encaixe entre Estado e sociedade (Skocpol, 1985, p. 26). ${ }^{6}$

Este locus de construção de significados políticos é ainda um encaixe entre "objetivos e capacidades" de grupos ativos e "pontos de acesso e influência" que são "permitidos pelas instituições políticas" nos processos de construção de políticas sociais.

Quando caracteriza sua "abordagem da polis" (polity approach), Skocpol (1992, p. 41; 1995, p. 105) se refere ao processo de:

[...] encaixe $[f i t]$ - ou a falta dele - entre os objetivos e capacidades de diversos grupos politicamente ativos e os historicamente mutáveis pontos de acesso e de influência permitidos pelas instituições políticas de uma nação.

\footnotetext{
6 As traduções são da autora do artigo.
} 
Nos processos de encaixe estão, por um lado, os atores sociais, com seus objetivos e capacidades, e, por outro, os pontos de acesso a instituições, permitidos por elas e historicamente mutáveis. Conforme observa Houtzager (2004, p. 32) por meio desses processos de encaixe "as instituições dão a alguns atores e alianças maior acesso e influência sobre centros públicos de tomada de decisões" e as características das instituições influenciam nas variadas possibilidades de "quais atores vão aproveitar o encaixe ou conseguir arquitetá-lo". Houtzager também assinala que a habilidade de atores estatais e societários de produzirem políticas inclusivas depende de sua capacidade de construir processos de encaixe e que essas novas capacidades de ação se formam "a partir de reiterados ciclos de interação" (2004, p. 32).

Neste trabalho escolhemos especialmente estas duas categorias - as coalizóes de defesa e os encaixes socioestatais - como instrumental analítico para avaliar a incidência do movimento na política pública, visando perscrutar as formas como um conjunto de atores sociais e estatais se vincula em alianças ou coalizões, que favorecem processos de encaixes socioestatais e assim consegue levar aos centros decisórios certos objetivos e demandas vinculadas ao paradigma garantista. Esse instrumental será utilizado para analisar os processos de incorporação de demandas civis na política socioeducativa, os processos por meio dos quais um conjunto de instituições estatais construídas a partir do paradigma menorista - legislações, políticas, estruturas de governo, instituições de execução das políticas, como a Febem/SP, os seus "Postos LA", sofre algumas mudanças, construindo-se novas instituições que incorporaram, em alguma medida, o paradigma garantista, com distintas demandas provenientes das lutas do movimento DCA.

\section{O caso empírico e a metodologia}

O movimento social pelos direitos da criança e adolescente, aqui chamado movimento DCA, em seus primeiros ciclos de 
mobilização, lutou pela incorporação do paradigma garantista na Constituição Federal e no ECA. Ele é um movimento heterogêneo, que se compõe de uma diversidade de organizações, que se articulam em fóruns, nos âmbitos nacional, estadual, municipal e, em São Paulo, regional. Em acordo com a concepção de Diani (1992, p. 1), é um conjunto heterogêneo integrado por diferentes organizações, grupos e indivíduos ativistas que, no entanto, têm identidades coletivas compartilhadas.

Procuramos mostrar como este movimento DCA atua, em São Paulo, na luta pelos direitos da criança e adolescente e produz efeitos na construção de políticas que visam garantir esses direitos, especialmente as voltadas aos adolescentes em conflito com a lei, as políticas socioeducativas.

Para isso examinamos três ciclos de mobilização do movimento DCA: (1) período das grandes rebeliões que levaram ao fim da Febem/SP e à criação do Sinase; (2) processo de municipalização da política socioeducativa em meio aberto em São Paulo; (3) elaboração do Plano Municipal Socioeducativo de São Paulo.

Esses foram três momentos em que o Estado absorveu, em alguma medida, o paradigma garantista, incorporando, em distintos graus, as demandas civis apresentadas pelo movimento. $\mathrm{O}$ primeiro deles ocorreu no âmbito estadual, mas teve impacto em mudanças no nível nacional e também na política municipal, que foi alvo das mobilizações do segundo e terceiro ciclos.

O procedimento metodológico ${ }^{7}$ adotado em cada um dos três ciclos de mobilização foi distinto: o primeiro foi estudado com base em pesquisa bibliográfica e documental, ${ }^{8}$ o segundo foi

7 O capítulo é fruto de pesquisa docente realizada entre 2010 e 2015. Durante a pesquisa a autora foi pesquisadora e docente do Mestrado Profissional Adolescente em Conflito com a Lei, da Unian, São Paulo, e a pesquisa fez parte de suas atividades contratuais.

8 Entre os documentos se destacam a Ata da CPI Febem (1998); Coletânea de Resoluções do Conselho Estadual de São Paulo - Condeca (1994-2002); Resoluções Condeca (28 jun; 28 out e 8 nov. 1999); notícias de jornal sobre 
estudado por meio de entrevistas em profundidade. ${ }^{9}$ No terceiro ciclo o principal instrumento de pesquisa foi a observação sistemática de reuniões de uma das organizações do movimento, a Articulação, com registro em diário de campo. ${ }^{10}$ Houve ainda um trabalho de assessoria feito pela autora a uma pesquisa realizada por um grupo de trabalho (GT) constituído na Articulação sobre a política municipal socioeducativa que resultou na publicação Albuquerque et al. (2014).

Em cada um dos ciclos de mobilização veremos como a formação de coalizões favoreceu processos de encaixe entre o movimento e o Estado, potencializando e alavancando a sua ação, e gerando efeitos de maior alcance. Essas categorias serão utilizadas para uma melhor compreensão da ação do movimento, buscando caracterizar seus efeitos e sua efetividade em alcançar seus objetivos de mudança institucional na política socioeducativa. Consideramos que o objetivo central do movimento nesses ciclos de mobilização foi conseguir que o paradigma garantista penetrasse nas políticas socioeducativas, fosse absorvido nas decisões e ações do Estado, modificando determinados aspectos das políticas socioeducativas nessa perspectiva.

os confrontos com a Febem (2003), Ata e Resolução do Fórum Estadual sobre o confronto com a Febem; Relatórios do TCU 2003, 2005, 2009, Acórdão 304/2004 (TCU), Relatório Ilanud 2007, ofícios da "Articulação" à prefeitura de São Paulo e ao poder Judiciário: DEIJ - Departamento de Execuções da Infância e Juventude de São Paulo.

9 Foram realizadas, em 2012, oito entrevistas, com sete pessoas que foram ativistas do movimento DCA em distintos momentos. Uma entrevista foi realizada com a Coordenadora de Proteção Social Especial da SMADS - Secretaria Municipal de Desenvolvimento e Assistência Social de São Paulo.

10 A "Articulação das Entidades que executam Medidas Socioeducativas em Meio Aberto em São Paulo" formou-se no ano 2000, ainda quando estas entidades eram conveniadas com a Febem e foi protagonista do processo de municipalização das medidas. Entre os anos 2012 e 2015, foi realizado acompanhamento sistemático das reuniões mensais da Articulação e ainda observadas e registradas em 2014 uma reunião com a Defensoria Pública, duas reuniões do Grupo de Trabalho (GT) do Plano Municipal. 


\section{O ciclo de rebelióes que levou ao "fim" da Febem/SP e ao Sinase}

Apesar da profunda mudança institucional que significou a aprovação do ECA, as políticas voltadas ao adolescente em conflito com a lei tardaram muito a mudar. ${ }^{11}$ As Febems, instituições menoristas da antiga Política Nacional de Bem-estar do Menor (PNBem) continuaram a funcionar com seus mesmos estatutos e mesmas burocracias que perpetuavam velhas metodologias de reeducação, privilegiando medidas privativas de liberdade. ${ }^{12}$

No Brasil, apesar do contexto internacional de fortalecimento do paradigma garantista, ${ }^{13}$ o contraste entre as normativas garantistas ditadas pelo ECA e a realidade menorista do funcionamento das instituições da justiça juvenil, especialmente a Febem/ SP explodiu, nos anos 1990 e 2000, em rebelióes e mortes. Essa explosão foi o momento de início de uma forte mobilização do movimento, que culminou com o "fim" da Febem/SP, ou melhor, com sua transformação em Fundação CASA, em 2006 e também, no plano nacional, com a aprovação pelo Conanda (Conselho Nacional dos Direitos da Criança e Adolescente), na mesma data, da primeira normativa sobre uma política pública garantista para o adolescente em conflito com a lei - o Sistema Nacional de Atendimento Socioeducativo - Sinase (Brasil, 2006). Esse ciclo de

11 Diversas análises enfatizam essa mudança tardia como os relatórios do Tribunal de Contas da União (TCU) (Brasil, 2005), e do Instituto Latino-Americano das Nações Unidas para Prevenção do Delito e Tratamento do Delinquente (Ilanud, 2007).

12 São as medidas socioeducativas de internação e semiliberdade.

13 O paradigma garantista penetra na regulação estatal brasileira na Constituição de 1988 e no ECA, em 1990. Internacionalmente ele se faz presente nas declarações da ONU em Beijing, 1985, nas Regras Mínimas das Nações Unidas para a Ảdministração da Justiça da Infância e da Juventude e em Riad, 1990, nas Diretrizes das Nações Unidas para a Prevenção da Delinqüência Juvenil, bem como, no mesmo ano, na Convenção Internacional sobre os Direitos da Infância (1989). 
mobilização, que ocorreu no estado de São Paulo e também em âmbito nacional, caracterizou as lutas sociais pelo fim da Febem e pela criação do Sinase.

Durante esse ciclo de mobilização ampliaram-se as coalizões que o movimento constituiu com atores sociais e políticos em vista de alcançar seus objetivos, provocando uma reconfiguração de seus repertórios organizacional e de interação socioestatal, e possibilitando alguns processos de encaixe mais profundo entre movimento e Estado, que conseguiram alavancar algumas mudanças relevantes.

Conforme a documentação estudada (ver nota 9) nota-se a ampliação de uma coalizão de defesa do paradigma garantista, contrária ao modelo e práticas da Febem/SP, com o surgimento e/ ou ativação de atores sociais e político-estatais. Além do protagonismo dos próprios adolescentes rebelados, entre os atores do movimento se destacam a Pastoral do Menor, os fóruns Municipal, Estadual e Nacional DCA, a Associação de Mães e Amigos da Criança e do Adolescente em Risco (AMAR), os Centros de Defesa da Criança do Adolescente (Cedecas), o Sindicato dos Trabalhadores em Entidades de Assistência ao Menor e à Família do Estado (Sitraemfa) e outras ONGs como Conectas Direitos Humanos, a Fundação Projeto Travessia e a Comissão Teotônio Vilela de Direitos Humanos. Destaca-se também a OAB (Ordem dos Advogados do Brasil, com sua Comissão de Direitos Humanos e subcomissão de Direitos da Criança e Adolescente), outras associações profissionais como os Conselhos de Psicologia (CRP) e de Assistência Social (CRESS), bem como ONGs internacionais como a Anistia Internacional. Entre esses atores estão os que integram o movimento propriamente dito, aqueles atores que se reuniram mais continuamente nos fóruns, e aqueles que se agregaram à coalizão nos momentos de pico das lutas.

Além de seu setor societal a coalizão envolveu também atores político-estatais nacionais e internacionais, de naturezas 
distintas, como a Comissão e a Corte Interamericana de Direitos Humanos (CIDH) da OEA, bem como setores do Estado, incluindo setores do poder legislativo federal e estadual, como a Comissão de Direitos Humanos da Alesp (Assemblia Legislativa de São Paulo), mobilizada para a investigação das denúncias, por meio da realização, na Alesp, de uma Comissão Parlamentar de Inquérito - a CPI da Febem, realizada entre 1997 e 1999 (Palheta, 2010, pp. 78, 161; Albuquerque, 2012). Envolveu setores do poder Judiciário, como o DEIJ (Departamento de Execuções da Vara de Infância e Juventude) da capital, bem como o Ministério Público (promotoria) do estado de São Paulo, ${ }^{14}$ e alguns segmentos do executivo, como funcionários da Febem e eventualmente alguns representantes de prefeituras municipais. Alcançou ainda os Conselhos Nacional e Estadual de Defesa dos Direitos da Criança e Adolescente - Conanda e Condeca, o Condepe - Conselho Estadual de Defesa dos Direitos da Pessoa Humana, Conselhos Tutelares e Associações de Conselheiros.

Embora com matizes políticas distintas, essas organizações atuaram conjuntamente ao longo do ciclo, compartilhando as crenças que caracterizam o paradigma garantista, bem como o objetivo de implantação das diretrizes do ECA no sistema socioeducativo e determinadas estratégias de modificação no funcionamento da Febem e do sistema da justiça juvenil como um todo. Entre as ações que realizaram conjuntamente, embora não todas o tempo todo, realizaram visitas às unidades conflagradas da Febem, para inspeção e apuração de denúncias, promoveram investigações, divulgaram relatórios, ${ }^{15}$ apresentaram denúncias por meio

14 Foram muito ativos, na coalizão, o DEIJ - Departamento de Execuções da Infância e Juventude (do Poder Judiciário) e o Ministério Público (Promotoria da Infância e Juventude). O Tribunal de Justiça do Estado de São Paulo foi ativo entre os opositores da coalizão. Ver Vicentin (2005, pp. 295, 309).

15 A Anistia Internacional realizou investigação que resultou, no ano 2000, no relatório "Desperdício de vidas" e a Corte de Interamericana de Direitos Humanos da OEA, em 2005, determinou providências específicas para 
da mídia, promoveram a mobilização nacional e internacional de atores societais e estatais. A coalizão utilizou repertórios institucionais típicos dos poderes Judiciário e Legislativo, como a CPI, o processo administrativo, a ação civil pública, o exame de corpo de delito, as liminares, os requerimentos ao Executivo, bem como repertórios extrainstitucionais como manifestações, seminários de denúncia, avaliação e elaboração de propostas, denúncias à mídia e aos órgãos da Justiça, visitas de inspeção às Unidades da Febem onde houve maus tratos, torturas e mortes. Embora se possa identificar uma atuação articulada entre os atores que lutaram contra a Febem e seu paradigma, e pela implantação do paradigma garantista na política socioeducativa, isso não significa homogeneidade na sua ação e declarações.

Observou-se também a constituição de uma coalizão contrária a essa envolvendo setores dos poderes legislativo, na Alesp, no executivo, especialmente o governo do estado e a direção da Febem, no Judiciário, contando com o Tribunal de Justiça do Estado e, inclusive setores do Sindicato, Sitraemfa.

As duas coalizões se articularam e se confrontaram desde os primórdios da mobilização. Desde 1992, até abril de 2001, bem antes da conclusão desse ciclo, podemos observar na cronologia apresentada em Vicentim (2005, pp. 295-307) a articulação de atores sociais, com representantes do Legislativo, ${ }^{16}$ do Ministério Público (Promotoria de Justiça da Infância e Juventude) e o DEIJ. Nota-se uma ação articulada entre o MP e o DEIJ, que reiteradamente sofre reação do Executivo estadual e do Tribunal de Justiça, que contestam juridicamente essas ações. Pode-se contar nesse período de rebeliões, pelo menos nove ciclos de avanços e retrocessos em que a Promotoria acolhe denúncias, realiza visitas aos estabe-

proteger adolescentes em estabelecimentos estatais de internação (Palheta, 2010, pp. 78, 161).

16 Deputados federais realizaram visitas às unidades da Febem, bem como a Comissão de Direitos Humanos da Alesp, a qual realizou ainda a CPI da Febem. 
lecimentos conflagrados acompanhada de organizações sociais, de deputados e de autoridades internacionais, move ações civis públicas e processos administrativos que exigem mudanças na Febem. A seguir os juízes do DEIJ acolhem esses processos e concedem liminares que os mandam cumprir. Por seu turno o Executivo recorre desses mandados e o Tribunal de Justiça cassa as liminares e suspende os efeitos das decisões judiciais anteriores.

Vemos assim a formação de encaixes entre o movimento social e setores do Legislativo e do Sistema de Justiça, que potencializam o alcance dos objetivos do movimento. A formação dos encaixes é mediada pelo conjunto de crenças que conforma o paradigma garantista, sendo, porém, confrontados com outra coalizão de atores sócio-estatais que não compartilha esses valores e crenças centrados fundamentalmente nos direitos dos adolescentes em conflito com a lei.

As mobilizações nacionais e internacionais provocaram também a constituição de vários Grupos de Trabalho interinstitucionais, visando elaborar propostas de reordenamento da Febem. Estes GTs raramente conseguiram envolver atores para além da sociedade civil e representantes dos Conselhos (especialmente Conanda, Condeca, Condepe e Conselhos Tutelares), além de representantes legislativos, funcionários da Febem, alguns outros representantes dos poderes Executivo e Judiciário do estado de São Paulo. Esses GTs, segundo Palheta (2010), apresentaram, ao governador e à Secretaria de Justiça, projeto para a redefinição da instituição. ${ }^{17}$ Formaram-se assim, no contexto dessa crise, alguns GTs que se apresentam como processos de encaixe entre Estado

17 Conforme Palheta (2010, p. 161), um desses GTs, em 1999 o Grupo de Trabalho para o Reordenamento da Febem elaborou um projeto entregue ao governador e à Secretaria de Justiça. O GT era integrado por diversos movimentos sociais, o Sindicato, Sitraemfa, a Subcomissão de Defesa dos Direitos da Criança e do Adolescente da OAB - Seção São Paulo, o Fórum Estadual de Defesa dos Direitos de Crianças e Adolescentes e outras organizações sociais. 
e movimento, embora bastante limitados na sua representação estatal.

Os GTs se tornam pontos de acesso do movimento ao Estado, embora mais pontuais, específicos e informais, alguns deles constituídos dentro de pontos de acesso mais duradouros e institucionalizados, como os Conselhos Nacional (Conanda) e Estadual (Condeca), onde representantes sociais e estatais estabelecem estratégias conjuntas que se expressam em suas recomendações e deliberações. ${ }^{18}$

$\mathrm{O}$ repertório de confronto do movimento contribuiu para o processo de construção dos encaixes, quando a pressão exercida pelas denúncias veiculadas pela mídia alcança a dimensão internacional. Por outro lado, algumas instituições estatais como o MP e o DEIJ abriram pontos de acesso possibilitando um diálogo mais intenso com segmentos do movimento social, já articulado em ampla coalizão.

A constituição da coalizão de defesa do paradigma garantista - o compartilhamento de crenças e estratégias de política pública que caracterizam esse paradigma também se destaca como essencial ao processo de formação dos encaixes. Sem esse compartilhamento de crenças e propostas os Conselhos poderiam imobilizar-se em uma atuação dissonante, visto que integrados por representantes de posições políticas opostas. Sem uma predominância da coalizão garantista eles não produziriam deliberações de condenação das políticas menoristas e de defesa de instituições e metodologias garantistas. $\mathrm{O}$ papel relevante da coalizão também se nota na constituição e atuação dos GTs, que, embora permeadas de rachas com setores do governo estadual, mantém na arena de debate os atores que defendiam princípios e estratégias garantistas.

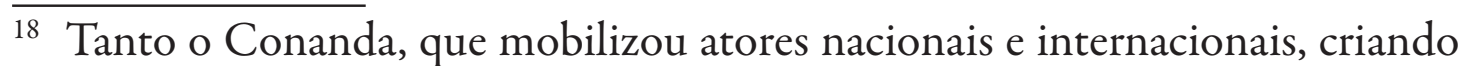
um dos GTs, como o Condeca foram fortemente ativos nesse período. O Condeca, por meio de sua Deliberação 15, proibiu, em 1999, a internação de adolescentes em uma das Unidades da Febem mais denunciadas. 
Esse ciclo chega, no final de 2006, ao fim da Febem, ou melhor, sua transformação em Fundação CASA, um pouco mais moldada pelo paradigma garantista. O sucesso decorrente desses processos de encaixe é, porém, cercado das limitações que se vão revelando na persistência do velho paradigma menorista no funcionamento da nova instituição. O movimento segue adiante redefinindo objetivos, estratégias e alianças.

Como decorrência desse momento de grandes crises no estado de São Paulo, a coalizão garantista ampliou seus objetivos, articulando-se pela construção das bases nacionais para uma política socioeducativa garantista - o Sistema Nacional de Atendimento Socioeducativo (Sinase). Na coalizão nacional se mantiveram as organizações da sociedade civil que já estavam articuladas, como a Pastoral do Menor, a ABMP (Associação Brasileira de Magistrados, Promotores de Justiça e Defensores da Infância e da Juventude), a Anced (Associação Nacional dos Cedecas) e outras organizações, entre as quais as integrantes do Conanda e outras, antigas participantes das lutas pelo paradigma garantista. Entre os atores estatais se destaca o protagonismo do Conanda, do Fórum Nacional de Organizações Governamentais de Atendimento à Criança e ao Adolescente (Fonacriad) e da Subsecretaria de Promoção dos Direitos da Criança e do Adolescente (SPDCA) da Secretaria Nacional de Direitos Humanos da Presidência da República (SDH/PR) e do Unicef (Fundo das Nações Unidas para a Infância). Agregaram-se atores presentes nas diversas regióes do país como juízes, promotores de justiça, conselheiros de direitos, técnicos e gestores de entidades executoras de atendimento socioeducativo.

Durante vários anos a coalizão realizou ações conjuntas, especialmente debates sobre as diretrizes para a política socioeducativa: 
Durante o ano de 2002 o Conanda e a Secretaria Especial dos Direitos Humanos (SEDH/SPDCA), em parceria com a Associação Brasileira de Magistrados e Promotores da Infância e Juventude (ABMP) e o Fórum Nacional de Organizações Governamentais de Atendimento à Criança e ao Adolescente (Fonacriad), realizaram encontros estaduais, cinco encontros regionais e um encontro nacional com juízes, promotores de justiça, conselheiros de direitos, técnicos e gestores de entidades e/ou programas de atendimento socioeducativo (BrasilConanda, 2006, p. 15).

A coalizão contou também com aliados atuantes nos órgãos de controle público estatal e de pesquisa que analisaram e denunciaram as péssimas condições das instituições privativas de liberdade: a "fragilidade do sistema de aplicação de medidas socioeducativas não privativas de liberdade, a baixa municipalização do sistema e a falta de unidades descentralizadas nos estados". ${ }^{19}$ Entre esses órgãos se destaca o IPEA (Instituto de Pesquisa Econômica Aplicada) e o TCU (Tribunal de Contas da União), que produziu relatórios nacionais de monitoramento das políticas para o Adolescente em Conflito com a Lei em 2003, 2005 e 2009 e o Acórdão 304, de 2004, que impôs metas de descentralização para essa política, entre outras adequações (Albuquerque, 2013). Novamente aqui se destaca que atuar articuladamente em uma coalizão tem um alcance político mais restrito que compartilhar um projeto político. Setores de órgãos públicos como o TCU e o IPEA atuaram, como revelam seus relatórios, na defesa de princípios do paradigma garantista, o que não significa a adesão de todo

\footnotetext{
19 Ver "Mapeamento da situação das unidades de execução de Medida Socioeducativa de Privação de Liberdade ao Adolescente em Conflito com a Lei” produzido em 2002 pelo IPEA e SNPDCA da Secretaria Especial dos Direitos Humanos, citado por Pastoral do Menor (2010, p. 26).
} 
o órgão à coalizão e nem mesmo uma atuação ativista em todo o funcionamento da coalizão.

Esse processo, com debates envolvendo atores sociais e estatais em todo o país, resultou na legislação recente que cria (Brasil, 2006) e regulamenta o Sinase, recentemente normatizado (Brasil, 2012; 2013). O próprio documento base reconhece essa ampla participação de atores quando pontua que o Sinase é construído como:

[...] fruto de uma construção coletiva que envolveu nos últimos anos diversas áreas de governo, representantes de entidades e especialistas na área, além de uma série de debates protagonizados por operadores do Sistema de Garantia de Direitos em encontros regionais que cobriram todo o País (Brasil, 2006, p. 13).

Os debates promovidos pela coalizão nacional, protagonizada pela ABMP, Unicef, Fonacriad e SPDCA revelam processos de encaixe socioestatal onde "diversos grupos politicamente ativos" com seus "objetivos e capacidades" puderam ter acesso potencializado às instituições governamentais. A Resolução do Conanda, de 2006, que cria o Sinase, é o resultado desse processo participativo. Os atores político-estatais, ou mesmo societais, porventura contrários ao paradigma garantista, não prevaleceram quando da sua promulgação.

Também nessa fase do ciclo, o sucesso desse processo foi limitado, persistindo no país a centralização e as práticas menoristas. Em 2007, o Ilanud (Instituto Latino-Americano das Nações Unidas para Prevenção do Delito e Tratamento do Delinquente) publicou o relatório de um mapeamento nacional no qual aponta esses limites. $\mathrm{O}$ relatório considera que, após quase duas décadas de promulgação do ECA, o estágio da municipalização era ainda “embrionário" (Ilanud, 2007, p. 15). 
A análise desse ciclo de mobilização mostra que as mudanças na política socioeducativa, aqui retratada pela situação da Febem/SP e pela construção do Sinase foram extremamente lentas sem afastar-se do paradigma menorista tanto na atuação dos burocratas do poder executivo estaduais (dirigentes e funcionários da Febem) e demais executivos que não priorizaram a descentralização, a municipalização e as medidas socioeducativas não privativas de liberdade. É notória a falta de capacidade estatal para a implementação do novo paradigma.

Por outro lado, a constituição e ampliação de uma coalizão de defesa do paradigma garantista, com seus reflexos agregadores na ação concertada em processos de encaixe sócio-estatal, foram essenciais para impulsionar rompimentos com o velho paradigma e para o processo que veio a construir parâmetros garantistas para a política socioeducativa, a partir do Sinase.

\section{A municipalização da política socioeducativa em meio aber- to}

O segundo ciclo de mobilização se refere ao movimento DCA no município e sua atuação nas medidas em meio aberto que, segundo o ECA e Sinase, são de responsabilidade municipal. ${ }^{20}$ Essa nova responsabilidade provocou reestruturações na política de assistência social no município e também no movimento DCA, onde surge um novo ator, ligado a essa política.

A municipalização da política socioeducativa em meio aberto também se segue às profundas crises nas instituições de privação de liberdade acima relatadas. Já a partir do ano 2000, no gover-

20 Esta seção foi elaborada com base em entrevistas em profundidade com atores societais e estatais envolvidos diretamente na municipalização, conforme citado anteriormente. 
no Lula, o governo federal institui programas ${ }^{21}$ com o objetivo de "ampliar e aperfeiçoar os serviços voltados para o cumprimento de medidas socioeducativas não privativas de liberdade" (Brasil, 2005).

Esse ciclo de mobilização do movimento foi precedido de experiências inovadoras desenvolvidas por uma de suas organizações - a Pastoral do Menor da Igreja católica, com projetos de Liberdade Assistida Comunitária (LAC). ${ }^{22}$ Essas experiências envolveram diversas organizações do movimento, como alguns Cedecas e a Pastoral, com as medidas em meio aberto, desenvolvendo uma importante expertise para a sua execução.

A partir dessas experiências surgiu em São Paulo, no ano 2000, uma articulação entre as organizações (ONGs) conveniadas com a Febem para a execução da Medida de LA. Esta "Articulação" (Articulação das Entidades que executam as Medidas Socioeducativas em Meio Aberto - Articulação MSE/ MA), um novo ator no movimento DCA, se tornou decisiva para deflagrar o processo de municipalização, tomando a iniciativa de provocar o debate sobre a municipalização, e ampliando uma coalizão em torno a esse objetivo.

Para tal, se formou em 2002, já no governo de Marta Suplicy, do Partido dos Trabalhadores (PT) uma Comissão Interinstitucional, incluindo secretarias do governo estadual e municipal, a Febem, o Unicef, os Conselhos Municipais de Assistência Social (Comas) e de Direitos da Criança e Adolescente

${ }^{21}$ O programa "Reinserção Social do Adolescente em Conflito com a Lei" consta do Plano Plurianual federal - PPA 2000/2003 e no PPA de 2004 a 2008 passa a se denominar "Atendimento Socioeducativo do Adolescente em Conflito com a Lei” (Brasil, 2005).

22 A Pastoral do Menor realizou Projetos de LAC em vinte estados do Brasil, entre 2002 e 2007. No estado de São Paulo a experiência já era desenvolvida desde os anos 1970, articulada com a Febem, que executava medidas de liberdade assistida por meio dos chamados "postos de LA" da Febem (Pastoral do Menor, 2010), que funcionavam nas diversas regiões do estado, na região metropolitana de São Paulo e na capital (Casa, 2010, pp. 13-125). 
(CMDCA), uma Comissão de Conselhos Tutelares, representantes do Ministério Público e a comissão de ONGs. O representante das ONGs, um dos fundadores da Articulação, passa a integrar a SAS (Secretaria Municipal de Assistência Social) e a coordenar $o$ processo de municipalização. ${ }^{23}$ Firma-se, então, um Termo de Compromisso e Cooperação Técnica entre a SAS e a Febem no qual o Município se propõe a implantar um novo modelo de Política de Proteção Social à Criança e Adolescente (Projeto Piloto). A implantação do Projeto Piloto recebe recursos financeiros do governo federal, já no governo Lula, também do Partido dos Trabalhadores.

Percebe-se dessa forma a construção de um processo de encaixe socioestatal, facilitado pelo trânsito de um ativista do movimento para o poder público, e pelo compartilhamento de crenças e propostas estratégicas entre eles. A Comissão Interinstitucional é um ponto de acesso ao Estado. Nela estão envolvidos setores do Estado e do movimento afinados com o paradigma (crenças core) e com os modelos de política garantistas (crenças específicas do setor da política pública), entre os quais setores do governo municipal. Dessa forma constituem uma coalizão que se une em torno das crenças e estratégias garantistas que se expressam na sua "Proposta de municipalização de medidas socioeducativas", apresentada em 2003, em audiência pública (São Paulo, 2004). No entanto, também participam desse trabalho atores que se opõem à coalizão, setores estatais que não compartilhavam essas crenças e estratégias de política pública, no governo estadual do PSDB (Partido da Social Democracia Brasileira) e na Febem, fundação estadual. É preciso, porém, destacar que o corte partidário não coincide com o conjunto de crenças que configura o paradigma garantista. Não há adesão homogênea a esse paradigma entre os atores estatais dos

23 As informações deste tópico foram obtidas em entrevista com esse ativista, que transitou, na ocasião, para o poder público, integrando o Executivo municipal. 
governos petistas e nem uma ausência total de adesão a ele entre os atores ligados ao governo do PSDB. Haja vista a participação de funcionários e da Associação de Funcionários da Febem (Afufe) na defesa de estratégias de mudança coerentes com o paradigma garantista.

O processo de encaixe desenvolve-se também na criação e implantação do Projeto Piloto, aprovado em 2004, para três distritos (São Paulo, 2004; Albuquerque, Oliveira e Botelho, 2013). Esse Projeto Piloto, desenhado pela coalizão de atores integrante da Comissão, recolhe a expertise e as tecnologias sociais acumuladas pelas ONGs que integravam a Articulação e absorvidas por sua vez da atuação da Pastoral do Menor, com a LAC, e de outras organizações que historicamente trabalharam no atendimento a crianças e adolescentes marcados pela exclusão social. Esse processo de encaixe entre o movimento e o executivo municipal é mediado também pelo ideário de um partido (PT) que defende a ampliação de direitos sociais e mantém laços fortes com o movimento, desde as lutas pela Constituinte.

Com a mudança de governo municipal - do PT para o PSDB - o encaixe sofre uma descontinuidade com a reestruturação da Secretaria de Assistência, que passa a se denominar SMADS, e com o abandono de muitos dos traços garantistas do modelo desenhado no Projeto Piloto (Oliveira, 2012, p. 22). Convênios se rompem e organizações do movimento se retiram em 2006. O inovador Projeto Piloto então se desfigura e acaba permanecendo uma política terceirizada, permeada de conflitos com as organizações sociais (ONGs) executoras.

Nota-se outra vez que a formação de uma coalizão favorece a constituição de encaixes socioestatais. No processo de municipalização da política em meio aberto, a coalizão garantista defendeu o direito de o adolescente permanecer em seu município, permitindo a convivência familiar e comunitária, uma crença específica dessa política, que integra o paradigma garantista. Conforme ensi- 
naram Sabatier e Weible (2007, p. 195) a coalizão integrou atores sociais e estatais que compartilharam essas crenças constitutivas da "visão que orienta o comportamento estratégico da coalizão", e que "ajudam a unir aliados e dividir adversários", e optaram pela estratégia de desenhar e implementar o Projeto Piloto, projetando "uma imagem de como o subsistema de política deveria ser".

A ação estratégica da coalizão ocorre no momento do encaixe socioestatal, especialmente na construção do Projeto Piloto em 2004, destacando-se o trânsito (Silva, 2011) de um ativista para o governo municipal. Esse trânsito entre movimento e Estado favoreceu a criação do "encaixe" socioestatal que envolveu a Articulação MSE/MA e outras organizações do movimento, com setores de governo federal e municipal integrantes de uma coalizão garantista. Esse "encaixe" favoreceu a incorporação pelo Estado de expertise e tecnologias sociais de ação junto às famílias e comunidade advindas da Pastoral do Menor, com a LAC. Ampliam-se assim, a partir do "encaixe", as limitadas capacidades estatais para a implantação da perspectiva garantista na Política Socioeducativa em Meio Aberto.

\section{A elaboração do Plano Decenal Socioeducativo no mu- nicípio de São Paulo}

O terceiro ciclo também se refere ao âmbito municipal, e conta com o protagonismo da Articulação MSE/MA, que cresceu nos anos em que a pesquisa foi realizada (2010 a 2015). Essa organização vive na interface entre duas identidades: uma organização de entidades executoras de convênios, mas que mantém, ao mesmo tempo, uma atividade voluntária e militante pela adequação das MSE/MA ao ECA, típica de uma organização do movimento social. Suas reuniões mensais contaram com uma participação continuada de cerca de trinta Serviços MSE/MA, cerca de metade do total. 
O reconhecimento desta Articulação pelo Estado, e os encaixes construídos na sua interação revelam nesse ciclo duas situações políticas distintas.

Nos anos em que o governo municipal esteve a cargo de partidos mais distantes do movimento DCA e de seu ideário garantista (prefeitos Serra e Kassab, do PSDB) foram bastante repetidas pelos participantes, nas reuniões observadas, as afirmações de que a prefeitura, a SMADS e os CREAS não "reconheciam" nem "valorizavam" a Articulação. Nesse período, no entanto, houve um importante reconhecimento dessa organização por setores do Sistema de Justiça ${ }^{24}$ (especialmente o Ministério Público e Defensoria Pública) que muitas vezes se apoiaram na relação com as organizações conveniadas (por meio dos seus relatórios) para exigir da prefeitura uma operacionalização adequada das normativas garantistas. A Articulação, por seu lado, se reuniu com juízes, promotores e defensores públicos para melhor encaminhar aspectos da atuação de ambas as partes, para avaliar e reivindicar melhorias na política municipal. Pode-se ver assim a formação de uma coalizão que busca implementar as diretrizes garantistas do ECA e do Sinase nos Serviços de Medida, e na política municipal socioeducativa.

Juízes, promotores e defensores públicos abrem pontos de acesso para o movimento levar ao Estado seus "objetivos e capacidades" de forma a melhor desenhar os instrumentos necessários à implementação da nova política, tais como o perfil de atuação dos juízes nas audiências, e o valor das verbas destinadas pelo Executivo às diversas atividades socioeducativas. Esses atores do

${ }^{24}$ O Sistema de Justiça é constituído pelo Judiciário, com seus juízes, o Ministério Público (procuradores do Estado e promotores de Justiça) e a Defensoria Pública, além das polícias. $\mathrm{Na}$ área da Infância existem as varas de apuração de infrações e de execução de medidas judiciais (neste caso o DEIJ). O MP atua na defesa de direitos como o direito à educação e à saúde, bem como o cumprimento do ECA, do Sinase, dos Planos e demais legislações em seu todo. Os defensores públicos devem atuar na defesa durante a apuração de responsabilidades. 
Sistema de Justiça buscam assim transferir ao executivo - SMADS e CREAS, agências estatais com pouca expertise no atendimento socioeducativo, uma certa "capacidade estatal" para a execução da política socioeducativa em meio aberto, capacidade que hoje ainda só os Serviços MSE/MA, operados por ONGs possuem, pois as capacidades para a execução das medidas em meio aberto ainda não foram assimiladas pelo Estado. Na pesquisa realizada pela Articulação em 2014, relatos dos técnicos dessas ONGs apontaram "o despreparo" de profissionais, visto que a "SMADS e os CREAS não conseguem supervisionar adequadamente os Serviços MSE/MA, pois lhes falta conhecimento da realidade dos adolescentes e dos Serviços" (Albuquerque et al., 2015, p. 64).

Nota-se uma relação em triângulo - atores estatais do Sistema de Justiça, comprometidos com as crenças do paradigma garantista, articularam-se com a organização do movimento social para pressionar outro ator estatal (a prefeitura) menos comprometido com esse paradigma e com menor capacidade de implementar a política do que o ator social.

Percebe-se assim a formação de alguns breves e efêmeros encaixes informais entre a Articulação e alguns órgãos do Sistema de Justiça. Por outro lado, não há encaixe com o Executivo.

A Articulação MSE/MA mostrou-se portadora dos objetivos e capacidades do movimento, pela atuação de especialistas orgânicos ao movimento: os técnicos dos Serviços de MSE, psicólogos, assistentes sociais e advogados. Muitos desses profissionais, presentes ao longo da história do movimento DCA, consolidaram sua atuação movimentista em um espaço organizativo, onde podem expressar e construir suas ideias, crenças e identidades, ainda que nem sempre compartilhadas pelos dirigentes das ONGs que gerem os Serviços e nem por grande parcela dos integrantes do Estado.

A coalizão que liga setores do Sistema de Justiça e a Articulação se forma na defesa do ideário do paradigma garantista 
e nem sempre coincide com o ideário de partidos políticos, pois atores estatais atuantes no Sistema de Justiça em geral não apresentam alinhamento partidário, ao contrário daqueles integrantes dos poderes Executivo e Legislativo.

Num segundo momento, durante o processo de elaboração do Plano Municipal de Atendimento Socioeducativo 2015-2025 25 se nota uma nova configuração nas coalizões e encaixes. Esse processo se iniciou por meio de interpelações da Articulação ao CMDCA e ao governo municipal, novamente petista (Fernando Haddad), ainda em 2013. Novamente aqui a formação da coalizão e o processo de encaixe são tributários da presença de antigos ativistas do movimento no Estado, um deles na Secretaria Municipal de Direitos Humanos e outro na SMADS. Crenças e linguagem em comum, confiança adquirida em lutas compartilhadas são fatores que contribuíram para um acolhimento recíproco. Quando a Articulação foi integrada ao GT que coordenou a elaboração do Plano consolida-se a coalizão e se constitui o processo de encaixe, à medida que esse ator ganha papel de destaque no processo.

O processo de encaixe é ativamente construído pela Articulação, desde as suas primeiras iniciativas, em 2013, seguidas da realização de uma pesquisa, em 2014, com vistas a contribuir para o Plano Decenal. ${ }^{26}$ Essa organização do movimento demonstrou assim sua capacidade de mobilização, de diagnóstico e de proposição política.

25 O Sinase determina a elaboração, com participação da sociedade, dos planos nacionais decenais socioeducativos, e um ano após a sua aprovação, a elaboração dos planos estaduais e municipais. O Plano Nacional foi aprovado em 2013 e 2014 seria o prazo para os demais.

26 A pesquisa foi realizada por um GT da Articulação e envolveu os técnicos e adolescentes integrantes do sistema municipal socioeducativo. A pesquisa teve a participação de 79 adolescentes e 125 técnicos, envolvendo trinta Serviços MSE/MA. A autora assessorou a realização dessa pesquisa cujos resultados foram publicados em Albuquerque et al., 2015. 
A pesquisa, publicada em 2015 (Albuquerque et al., 2015), avalia a política municipal, denunciando graves violaçóes de direitos dos adolescentes em toda a rede de serviços públicos que atendem os adolescentes infratores destacando a "discriminação e estigmatização em toda a rede intersetorial de serviços públicos: educação, saúde, lazer, cultura, esporte, segurança pública e poder judiciário" (p. 64). Aponta também a baixa capacidade estatal de gestão da política municipal socioeducativa pela SMADS, destacando que a "SMADS e os CREAS ainda não têm estrutura e recursos humanos para realizar o acompanhamento e coordenação adequados dos Serviços" (p. 67). A "terceirização" dos Serviços, mediante conveniamento com as entidades executoras é considerada fonte de importantes problemas entre os quais a insuficiência dos recursos de financiamento e a "descontinuidade do financiamento em face do processo de renovação dos convênios”. A baixa capacidade estatal aparece ainda na dificuldade de articulação com as políticas de educação (especialmente a dificuldade de assegurar a vaga do adolescente nas escolas), saúde e outras políticas de garantia dos direitos sociais.

Entre os limites, alguns dramáticos, estão as dificuldades de relação com os órgãos policiais e com o Judiciário.

Ao Sistema de Justiça, no entanto, cabem as críticas mais severas, ligadas ao desrespeito de direitos humanos e de cidadania, como a não oitiva de adolescentes e familiares, e as agressões físicas e morais por parte de policiais. [...] o Poder Judiciário desconhece a realidade dos adolescentes, de suas famílias e da rede pública que poderia apoiá-los, desconsiderando assim as dificuldades ligadas às exigências que colocam para o encerramento da Medida (Albuquerque et al., 2015, p. 66). 
A partir de sua análise, as principais sugestões que surgem na pesquisa vão no sentido de que a política municipal socioeducativa, com seus Serviços, seja integralmente assumida pelo poder público, que esse se capacite na temática socioeducativa e que SMADS assuma um protagonismo decisivo na construção de relações de efetiva parceria com a rede pública intersetorial e os Serviços de Medidas (SMSE/MA).

A pesquisa demonstrou uma importante capacidade analítica e propositiva da Articulação, reconhecida pela SMADS ao convidá-la para apresentar a pesquisa ao "GT do Plano" em seminários ampliados com as secretarias municipais afetas a essa política e demais convidados e ao utilizá-la amplamente para a elaboração da minuta do plano. ${ }^{27}$ As três pessoas da Articulação integrantes do GT do Plano protagonizaram, junto com os dois representantes da SMADS todo o processo de elaboração do Plano, a coordenação das audiências públicas e a sistematização final. Em agosto de 2015, após as consultas públicas, a minuta do plano passou pela aprovação do CMDCA. O Plano, no entanto, só foi apresentado ao público em dezembro de 2016, ao final do mandato do prefeito, derrotado nas urnas, sem ser referendado nem por decreto do Executivo e muito menos por meio de lei municipal, o que demonstra a fraqueza institucional que o cerca. Não sabemos até onde vão as mudanças institucionais geradas nesse processo, e até que ponto elas serão capazes de impactar as capacidades do Estado, adequando-as às exigências do paradigma garantista.

Num contexto de fraqueza institucional, no qual SMADS demonstrou pouca força política para convocar as secretarias relacionadas com a política socioeducativa e representantes do

27 Podem-se notar no texto do Plano Decenal as inúmeras referências à Pesquisa da Articulação. O Plano Municipal foi aprovado pelo CMDCA e divulgado em ato solene realizado em 8 dez. 2016. http://www.prefeitura.sp.gov.br/ cidade/secretarias/upload/assistencia_social/arquivos/Protecao/Especial/ MINUTAPLANOSOCIOEDUCATIVO.pdf. 
Judiciário, o funcionamento do GT do Plano mostrou importante momento de encaixe socioestatal, com destacado protagonismo arquitetado pela Articulação, e conseqüente acesso das demandas societais ao Estado.

No entanto, para que esse Plano se torne um instrumento de política municipal será necessário um processo mais amplo de mudanças. Entre elas ampliar a baixa capacidade orçamentária e de coordenação da SMADS em relação ao conjunto de atores estatais dos quais depende essa política. A política municipal socioeducativa ainda é hoje uma política totalmente terceirizada e sem recursos suficientes.

Ao contrário do que observaram Amenta et al. (2010) estudamos aqui a participação de uma organização do movimento para além da fase de definição da agenda, atuando nas fases de elaboração, implementação, avaliação e redesenho da nova política socioeducativa. Ao contrário das perspectivas que sugerem que a participação do movimento na implementação de políticas por meio de convênios com o Estado significa necessariamente sua cooptação à lógica estatal, vemos que essa experiência lhe dá uma expertise que qualifica sua capacidade crítica e propositiva, qualificando-o para o exercício do controle social e colocando-o na arena decisória de formulação da política.

\section{Instrumentos analíticos para avaliar a incidência do movi- mento na política pública: coalizões e encaixes}

Nosso objetivo neste capítulo foi analisar as formas como "o movimento importa” para as mudanças na política socioeducativa. Procuramos instrumentos analíticos para ver com mais cuidado o lugar e o sentido do movimento num contexto de construção democrática, onde seus objetivos se concentram na conquista e efetivação de políticas públicas que garantam os direitos pelos quais lutam. Buscamos iluminar aspectos da interação socioestatal, que 
já foi considerada um desvio, ameaça ou defeito, percebendo-a aqui como algo essencial aos objetivos do movimento. Dentre os instrumentos analíticos experimentados, a formação de "coalizões de defesa" e de "encaixes socioestatais" permitiu olhar com mais detalhe a relação entre organizações do movimento e as mudanças institucionais na política pública.

No Quadro a seguir organizamos uma síntese da análise realizada por meio dessas duas categorias. Nossa conclusão ilumina a relação entre as coalizões de defesa e os encaixes socioestatais. O Quadro procura mostrar, nos três ciclos estudados, os fatores relevantes para a construção de processos de encaixe socioestatal, destacando que a amplitude das coalizões, com o compartilhamento de crenças e estratégias que as articula, potencializado pelo trânsito de ativistas entre Estado e sociedade, é essencial ao maior potencial dos encaixes socioestatais. ${ }^{28}$

${ }^{28}$ A coluna com dados das coalizões de oposição serve como contrarreferência em algumas análises. 
Quadro 1: Fatores que favorecem a construção de encaixes socioestatais

\begin{tabular}{|c|c|c|c|}
\hline 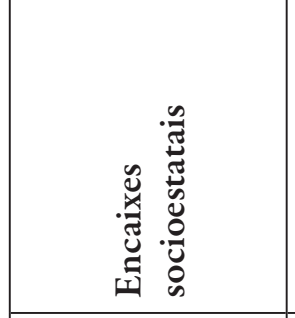 & 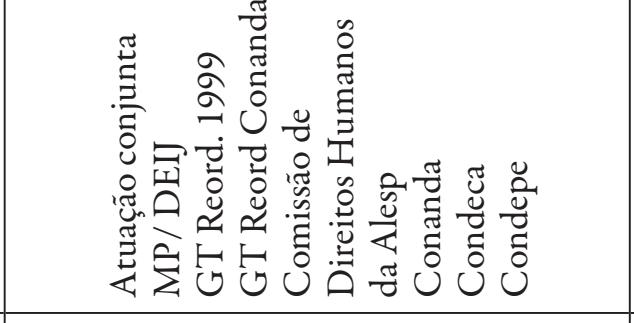 & 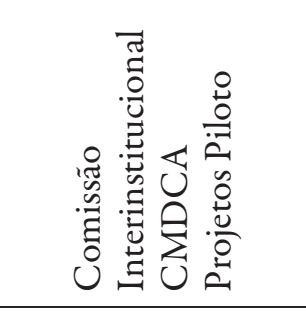 & 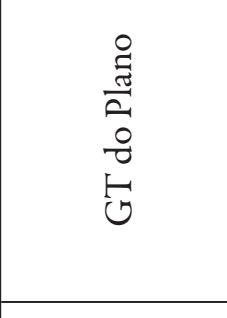 \\
\hline 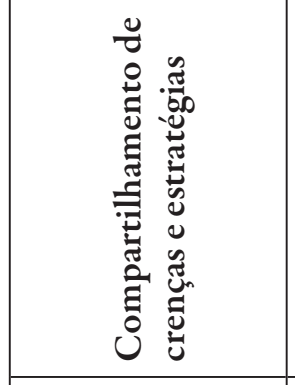 & 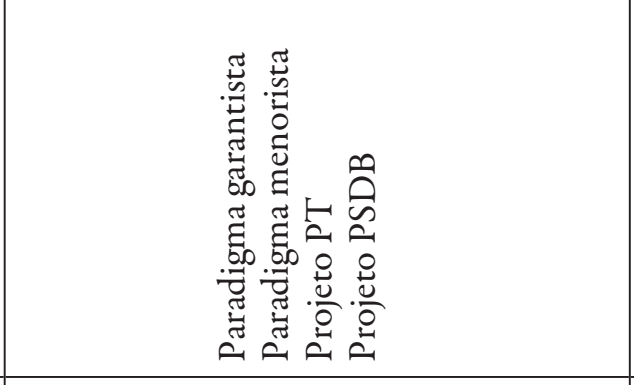 & 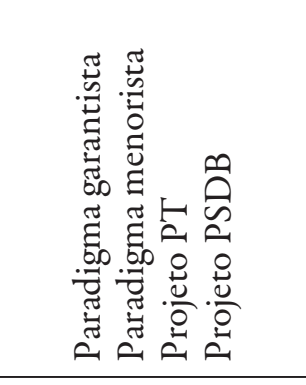 & 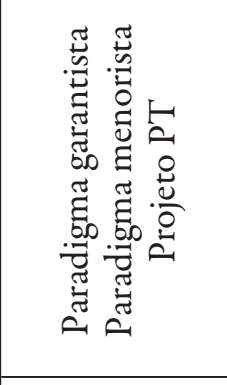 \\
\hline 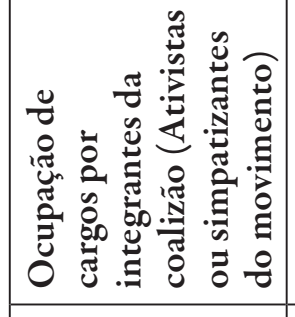 & 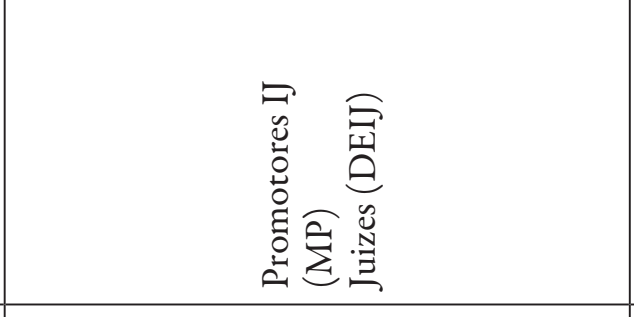 & 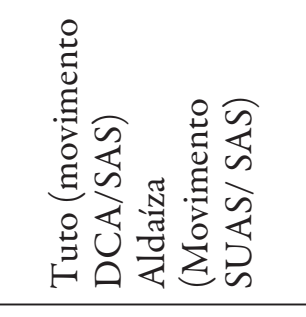 & 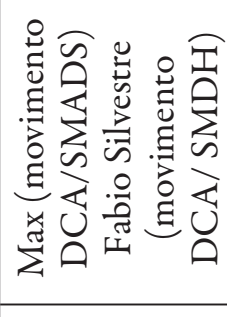 \\
\hline 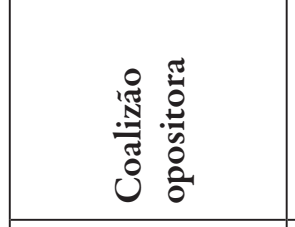 & 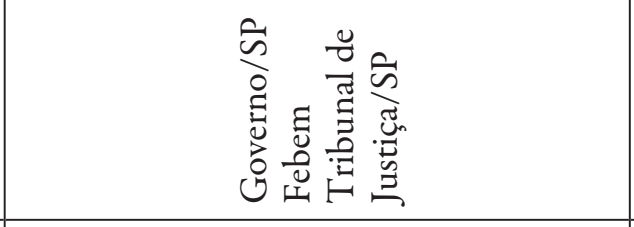 & 空空 & 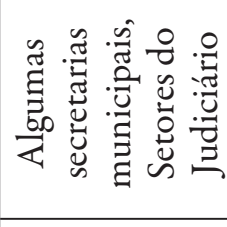 \\
\hline 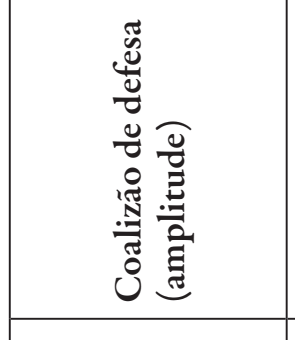 & 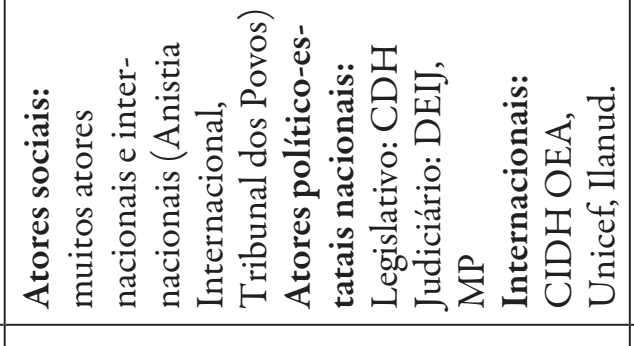 & 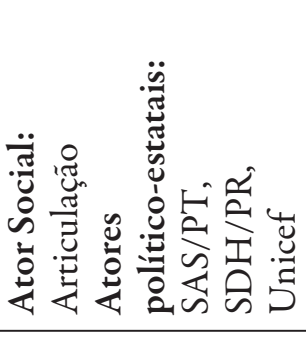 & 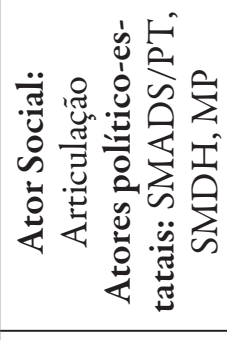 \\
\hline 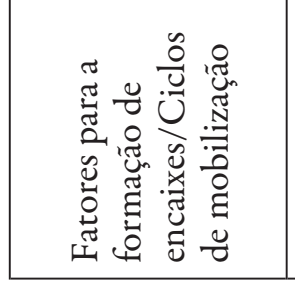 & 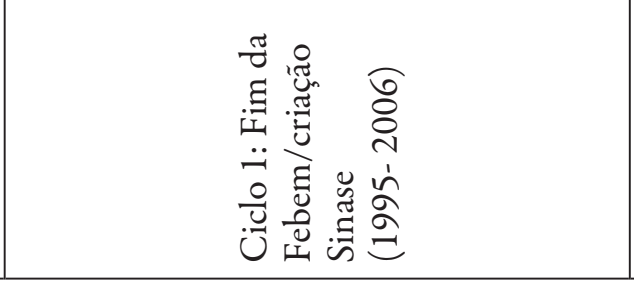 & 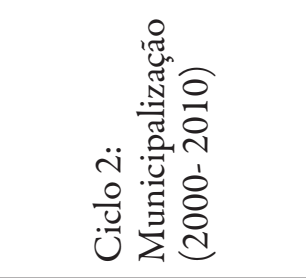 & 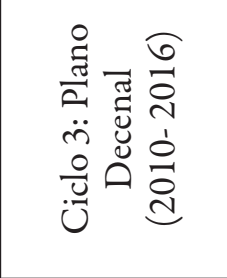 \\
\hline
\end{tabular}

Fonte: Elaboração da autora. 
Vemos, nos três ciclos estudados, a formação de coalizões de defesa que articularam atores societais e estatais, com base em dois grandes conjuntos de ideias - os paradigmas menorista e garantista, que são compartilhados por organizações do movimento, outros atores sociais e atores político-estatais. Esses paradigmas fundamentam coalizões, com recortes específicos em cada campanha, capazes de articular ações e estratégias dos atores sociais e político-estatais em torno dos objetivos de cada campanha. Esses objetivos, embora distintos, podem ser sempre descritos como a concretização do paradigma garantista nos aspectos da política pública enfatizados em cada um dos ciclos.

Embora não haja uma correspondência direta entre esses dois paradigmas e os projetos político-partidários dos dois partidos à frente do executivo (PT e PSDB) nos ciclos analisados, vemos que esses projetos também são fatores que contribuem para a articulação de coalizões de defesa e de oposição ao ideário e objetivos do movimento.

Percebe-se também que os processos de encaixe, e a própria formação das coalizões são tributários de um fenômeno descrito como o trânsito de ativistas entre Estado e movimento (Silva, 2011). Nos Ciclos 2 e 3 vemos a presença de antigos ativistas do movimento no Estado e a ocupação de cargos no Estado é mediada pelo compartilhamento de projetos político-partidários, no caso, em governos do PT. No Ciclo 1 temos o ativismo institucional de defensores e promotores públicos e de alguns juízes, que não são ativistas político-partidários, mas compartilham crenças e estratégias de política pública que caracterizam a coalizão de defesa do paradigma garantista. Em ambos os casos de ativismo institucional, as crenças, a linguagem comum e confiança adquirida em lutas compartilhadas são fatores que contribuem para um acolhimento recíproco, que reforça a coalizão e favorece processos de encaixe e sintonia fina que potencializam os resultados e impactos da coalizão na política pública. 
Embora sem compartilhar grandes projetos de sociedade, as coalizões mostram-se capazes de mover estratégias de atores que compartilham crenças mais profundas e amplas (core), como os direitos humanos de adolescentes, e crenças vinculadas à operacionalização das políticas socioeducativas, como a primazia de atendimentos em meio aberto em relação às instituições totais, entre outras. Vemos assim que também as ideias importam (Tomazini e Lukic, 2013) e que o conceito de coalizão de defesa pode ligar ideias e estratégias políticas concretas.

Os momentos de encaixe, ajuste ou sintonia fina, quando o movimento se torna capaz de ocupar pontos de acesso e alavancagem das demandas civis ao Estado são aqueles em que temos amplas coalizões de defesa do paradigma garantista, com o compartilhamento de um ideário e propostas de formatos de política sintonizados com este paradigma. Destacam-se, no Ciclo 1, de mobilização contra a Febem e pelo Sinase, os encaixes com uma parte do Sistema de Justiça que defende o paradigma garantista. Essa parte se vinculou, repetida e iterativamente, de forma proativa com atores sociais buscando avançar na operacionalização de uma política pública garantista, enquanto outra parte manteve seu apego à lógica e aos procedimentos menoristas.

Os processos de encaixe ocorrem no interior de espaços de proposição conjunta de novas políticas que incorporam o "novo paradigma". São exemplos os GTs que redesenharam a Febem, o Projeto Piloto municipal, o Plano Municipal Decenal Socioeducativo. A constituição desses GTs foi tributária de militantes institucionais, cuja atuação construiu viabilidades, sintonia fina e alavancagem das propostas garantistas. Destacaram-se também os Conselhos, especialmente o Conanda, Condeca e CMDCA, espaços muito heterogêneos, onde estratégias garantistas foram potencializadas em função da força da coalizão garantista. Nota-se que a formação dos encaixes é mediada pelo conjunto 
de crenças que conforma o paradigma garantista e que constitui coalizões que agiram na sua defesa ao longo do processo.

Não se pode pensar em sucessos ou fracassos absolutos no alcance das demandas civis ou objetivos do movimento. As conquistas são sempre parciais, e estão principalmente nas normativas que definem novas políticas de garantia de direitos. Maiores dificuldades estão na sua implementação, pois permanecem instituições, comportamentos e culturas arraigadas no paradigma menorista. Faltam também capacidades estatais para a implementação das novas políticas, capacidades estas que, por meio dos “encaixes”, são apreendidas das organizações do movimento, que colocam sua expertise na elaboração de novas propostas, como no caso do Projeto Piloto, em 2004 e do Plano Municipal Decenal, em 2015.

A situação de contínua parcialidade dos sucessos do movimento exige um contínuo repensar de objetivos, repertórios, estratégias, alianças - o movimento muda quando passa a interagir com outros atores. Conforme apontam Amenta et al. (2010, p. 14.13) vemos o movimento "alterar suas estratégias e formas direcionando-as para o contexto político específico”. Essa continuada alteração de estratégias se vincula com uma continuada formação de coalizões, ao longo dos três ciclos, em torno de um núcleo de atores que luta pelo paradigma garantista. A formação de coalizões mostra a forma como o movimento é proativo, arquitetando condições que permitem os encaixes. Se olharmos a continuada relação do movimento com setores do Sistema de Justiça na busca de conquistar influência junto ao Executivo vemos como a construção dos encaixes usa iniciativas que acumulam poder de forma iterativa e que, ao mesmo tempo, aproveita condições estruturais dos pontos de encaixe.

Muito embora os atores menoristas permaneçam com força no campo dessa política, ${ }^{29}$ as coalizões garantistas favorecem a

29 Vale investigar se a persistência do poder decisório dos atores menoristas impede considerar os processos acima como de formação de um "domínio" de agência das coalizões garantistas. 
sucessiva formação de encaixes socioestatais que colocam os atores garantistas entre aqueles relevantes como decisores na política socioeducativa.

\section{REFERÊNCIAS}

ABERS, Rebecca; SERAFIM, Liza; TATAGIBA, Luciana. Repertórios de interação Estado-sociedade em um Estado heterogêneo: a experiência na era Lula. Dados, 2014, v. 57, n. 2, pp. 325-357. Disponível em: <http://dx.doi. org/10.1590/0011-5258201411>.

ABERS, Rebecca; VON BÜLOW, Marisa. Movimentos sociais na teoria e na prática: como estudar o ativismo através da fronteira entre Estado e sociedade. Sociologias, 2011, ano 13, n. 28, pp. 52-84.

ALBUQUERQUE, Maria do Carmo (Org.). Participação popular em politicas públicas: espaço de construção da democracia brasileira. São Paulo: Instituto Pólis, 2006. Disponível em: <http://polis.org.br/publicacoes/participacao-popularem-politicas-publicas-espaco-de-construcao-da-democracia-brasileira/ $>$.

ALBUQUERQUE, Maria do Carmo. Novos atores e repertórios de ação no movimento pelos direitos do adolescente: repensando a institucionalização. Serviço Social em Revista, 2012, v. 15, n. 1, pp.166-189.

ALBUQUERQUE, Maria do Carmo. O movimento pelos direitos da criança e do adolescente e o controle social sobre a política socioeducativa: repertórios de interação socioestatal. Política e Sociedade, 2015, v. 14, n. 29, pp. 31-66.

AlBUQUERQUE, Maria do Carmo; BOTELHO, Dayana; OlIVEIRA, Adriano. A municipalização das medidas socioeducativas em meio aberto em São Paulo (SP) e Pouso Alegre (MG). Revista Brasileira Adolescência e Conflitualidade, 2013, n. 9, pp. 25-47.

ALBUQUERQUE, Maria do Carmo et al. Medidas socioeducativas em conflito: um diagnóstico a partir das equipes técnicas e adolescentes do meio aberto. Revista Brasileira Adolescência e Conflitualidade, 2014, n. 11, pp. 30-69.

AMENTA, Edwin. When Movements Matter: The Townsend Plan and the Rise of Social Security. Princeton, NJ: Princeton University Press, 2006. 
AMENTA, Edwin et al. The Political Consequences of Social Movements. Annual Review of Sociology, 2010, n. 36, pp. 14.1-14.21. Disponível em: <www. soc.annualreview.org>.

ARRETCHE, Marta. A agenda institucional. Revista Brasileira de Ciências Sociais, 2007, v. 64, pp. 1-9.

BRASIL. Tribunal de Contas da União (TCU). Secretaria de Fiscalização e Avaliação de Programas de Governo. Relatório de monitoramento: Programa Reinserção Social do Adolescente em Conflito com a Lei (TC n.011.261/2005-6). Brasília: TCU, 2005.

BRASIL. Secretaria Especial dos Direitos Humanos (SEDH/PR). Sistema Nacional de Atendimento Socioeducativo (Sinase). Brasília: Conanda, 2006.

BRASIL. Presidência da República. Lei n.12.594, de 18 de janeiro de 2012. Sistema Nacional de Atendimento Socioeducativo (Sinase). Brasília, 2012. Disponível em: <http://www.planalto.gov.br/ccivil_03/_ato20112014/2012/lei/112594.htm>.

BRASIL. Secretaria Especial dos Direitos Humanos (SDH/PR). Plano Nacional de Atendimento Socioeducativo (Sinase): diretrizes e eixos operativos para o Sinase. Brasília: SDH/PR, 2013.

CARLOS, Euzeneia. Movimentos sociais e instituições participativas: efeitos organizacionais, relacionais e discursivos. Tese (Doutorado em Ciência Política) - Universidade de São Paulo, São Paulo, 2012.

CARLOS, Euzeneia; DOWBOR, Monika; ALBUQUERQUE, Maria do Carmo. Movimentos sociais e seus efeitos nas políticas públicas: balanço do debate e proposições analíticas. Civitas, 2017, v. 17, n. 2, pp. 360-378.

DAGNINO, Evelina. Construção democrática, neoliberalismo e participação: os dilemas da confluência perversa. Politica e Sociedade, 2004, n.5, pp. 139-164.

DAGNINO, Evelina. Civil Society in Latin America. In: Michael Edwards (Org.). The Oxford Handbook of Civil Society. Oxford: Oxford University Press, 2011.

DIANI, Mario. The concept of social movement. The Sociological Review, 1992, v. 40, n. 1, pp. 1-25. 
DOWBOR, Monika. A arte da institucionalização: estratégias de mobilização dos sanitaristas (1974-2006). Tese (Doutorado em Ciência Política) Universidade de São Paulo, São Paulo, 2012. Disponível em: <http://dx.doi. org/10.11606/T.8.2012.tde-06032013-111003>.

GARCIA, Marco Aurélio. Construindo o poder popular: o sexto sentido. Produção: Instituto Cajamar. São Paulo: Instituto Cajamar, 1992. Vídeo (Coleção Popular).

GURZA LAVALlE, Adrián; SZWAKO, José. Sociedade civil, Estado e autonomia: argumentos, contra-argumentos e avanços no debate. Opinião Pública, 2015, v. 21, n. 1, pp. 157-187.

HOUTZAGER, Peter. Além da sociedade civil e do Estado: autoridade política, instituições e mobilização popular. In: Houtzager, Peter. Os últimos cidadãos: conflito e modernização no Brasil rural (1965-1995). São Paulo: Globo, 2007.

ILANUD. Instituto Latino-Americano das Nações Unidas para Prevenção do Delito e Tratamento do Delinquente. Mapeamento nacional de medidas socioeducativas em meio aberto: relatório resumido. Brasília: Ilanud/SEDH, 2007.

MCADAM, Doug; TILLY, Charles; TARROW, Sidney. Para mapear o confronto político. Lua Nova, 2009, v. 76, pp. 11-48.

PALHETA, Adriana. Sociedade civil, direitos humanos e adolescente em conflito com a lei. Dissertação (Mestrado Profissional Adolescente em Conflito com a Lei) - Universidade Bandeirante, São Paulo, 2010.

PASTORAL DO MENOR. Liberdade assistida: um projeto em construção. Belo Horizonte: Pastoral do Menor, 2010.

SABATIER, Paul; WEIBLE, Christopher. The Advocacy Coalition Framework: Innovations and Clarifications. In: Sabatier, Paul; Weible, Christopher (Ed.). Theories of the Policy Process. Boulder, CO: Westview Press, 2007, pp. 189-222.

SADER, Eder. Quando novos personagens entraram em cena. Rio de Janeiro: Paz e Terra, 1988.

SÃO PAULO (Cidade). Secretaria Municipal de Assistência Social (SAS). As Medidas socioeducativas em meio aberto como garantia de proteção aos adolescentes e jovens da cidade de São Paulo. São Paulo: SAS/SEDH, 2004. 
SÃO PAULO (Cidade). Secretaria Municipal de Desenvolvimento e Assistência Social (SMADS). Plano Municipal de Atendimento Socioeducativo. São Paulo: SMADS, 2015. Disponível em: <http://www.prefeitura.sp.gov. $\mathrm{br} /$ cidade/secretarias/upload/assistencia_social/arquivos/Protecao/Especial/ MINUTAPLANOSOCIOEDUCATIVO.pdf>. Acesso em: 7 nov. 2013.

SÃO PAULO (Estado). Conselho Estadual dos Direitos da Criança e do Adolescente (Condeca). Deliberações 1994-2002. Condeca/SP: Trabalho conjunto em uma década. São Paulo: Condeca, 2002. Disponível em: <http:// www.condeca.sp.gov.br/arquivos/Livro_Condeca.pdf>. Acesso em: 7 nov. 2013.

SILVA, Marcelo K.; OLIVEIRA, Gerson. A face oculta(da) dos movimentos sociais: trânsito institucional e intersecção Estado-Movimento: uma análise do Movimento de Economia Solidária no Rio Grande do Sul. Sociologias, 2011, ano 13, n. 28 , pp. 86-124.

SKOCPOL, Theda. Bringing the State Back In: Strategies of Analysis in Current Research. In: Evans, Peter; Rueschemeyer, Dietrich; Skocpol, Theda (Ed.). Bringing the State Back In. Cambridge, UK: Cambridge University Press, 1985.

SKOCPOL, Theda. Protecting Soldiers and Mothers: The Political Origins of Social Policy in the United States. Cambridge, MA: Harvard University Press, 1992.

SOMARRIBA, Mercês. Movimento reivindicatório urbano e política em Belo Horizonte. In: Neves, Magda de Almeida; Dulci, Otávio Soares (Org.). Poder, politica e movimentos sociais, Belo Horizonte: C/Arte, 1996.

SZWAKO, José. Incorporação estatal e reprodução institucional: ou como observar os efeitos institucionais da ação coletiva. In: Congresso Internacional da Latin American Studies Association (LASA), 31., 2013, Washington, DC. 2013.

TARROW, Sidney. O poder em movimento: movimentos sociais e confronto politico. Petrópolis: Vozes, 2009.

TATAGIBA, Luciana; TEIXEIRA, Ana C. Efeitos combinados dos movimentos de moradia sobre os programas habitacionais autogestionários. Revista de Sociologia Politica, 2016, v. 24, n. 58, pp. 85-102.

TILLY, Charles. Movimentos sociais como política. Revista Brasileira de Ciência Politica, 2010, n. 3, pp. 133-160. 
TOMAZINI, Carla Guerra; LUKIC, Melina Rocha. As ideias também importam: abordagem cognitiva e politicas públicas no Brasil. Curitiba: Juruá, 2013.

VICENTIN, Maria C. A vida em rebelião: jovens em conflito com a lei. São Paulo: Hucitec/Fapesp, 2005. 



\section{SEGUNDA PARTE \\ Movimentos, raça, gênero e políticas públicas}





\section{Capítulo 5 \\ Antirracismo, movimentos Sociais \\ E EsTAdo (1985-2016)}

Flavia Rios

\section{Introdução}

No último ciclo democrático brasileiro (1985-2016), ${ }^{1}$ o movimento negro e suas reivindicações passaram por um processo de institucionalização jamais visto em sua história. Ao analisar a trajetória do movimento social nas últimas quatro décadas, percebe-se que, se o ambiente de contestação contra o regime militar de meados dos anos 1970 favoreceu o ressurgimento da mobilização negra, o crescimento e a diferenciação do ativismo dependeram do modo como os seus agentes relacionaram-se com o Estado e com outras instituições e organizações políticas, religiosas e filantrópicas (como a Fundação Ford, a Igreja católica, os partidos e os sindicatos) e com os demais movimentos, especialmente, o feminista, durante o processo de transição democrática (Gonzalez, 1982; Hanchard, 2001; Guimarães, 2001). Essa rede ampla de ativismo, que envolveu concorrência, cooperação e autonomia políticas, foi decisiva para o fortalecimento da mobilização coletiva bem como para garantir sua voz e visibilidade na sociedade civil e no Estado.

1 O período recortado compreende o intervalo temporal que vai da democratização do Brasil à ruptura institucional, gerada por uma profunda crise política, que levou ao impeachment de Dilma Rousseff, entendido aqui como uma ruptura democrática. Uma interpretação de fatores relevantes para a explicação da referida crise pode ser encontrada em Santos e Szwako (2016). 
No período recortado, são dois os principais momentos que marcam a trajetória do movimento negro: o primeiro relacionado à formação da identidade coletiva, que ocorreu durante os anos de contestação e de transição do regime político; e o segundo referente à sua institucionalização, que se intensifica no período de pós-transição democrática, envolvendo as dimensões interna e externa ao movimento social, isto é, a formalização, racionalização e profissionalização das organizações civis e a abertura e criação de espaços de mediação e de controle no interior do Estado. Em outras palavras, referem-se à institucionalização pública não-estatal e à institucionalização pública estatal, respectivamente. Desse modo, a institucionalização remete aqui ao duplo sentido: seja a institucionalização no movimento social mediante a reconfiguração de sua estrutura organizacional, seja a institucionalização na esfera do Estado por meio da construção de encaixes institucionais e seus resultados em termos de incorporação da agenda societal.

A contribuição deste capítulo consiste na reconstrução desse processo de institucionalização do movimento negro brasileiro, considerando alguns contextos políticos relevantes tais como a redemocratização, o processo constituinte e a campanha pelas ações afirmativas. Em sua trajetória de institucionalização o movimento interage de formas distintas com o Estado, em diferentes níveis de governo, produzindo "encaixes institucionais" que visam a inclusão da igualdade racial na agenda política. ${ }^{2}$ São três as estruturas de mediação socioestatal analisadas mais detidamente, as quais correspondem a encaixes institucionais por terem logrado certo grau de solidificação nas burocracias do Estado, a saber: o Conselho de Participação e Desenvolvimento da Comunidade Negra do Estado de São Paulo (CPDCN ); a Fundação Cultural Palmares (FCP) e a Secretaria de Promoção à Igualdade Racial (Seppir).

2 Para o conceito de encaixes institucionais remeto à Introdução deste livro. 
A análise se baseia em estudo de profundidade do movimento negro brasileiro, ao longo de quarenta anos. Trata-se de uma pesquisa de tipo qualitativa, que envolveu coleta e análise documental nos acervos públicos brasileiros, com destaque para a investigação dos jornais da imprensa negra e para os documentos governamentais. Trabalhou-se também com entrevistas estruturadas realizadas com ativistas, além de consulta à bibliografia especializada no assunto. Ademais, as reflexões aqui apresentadas estão ancoradas nas pesquisas realizadas por mim durante o mestrado e o doutorado. ${ }^{3}$

Este capítulo sustenta o argumento de que a institucionalização da agenda da igualdade racial no Brasil, no bojo da institucionalização do movimento negro e da construção de encaixes institucionais, está menos relacionada à representação eleitoralmente autorizada na esfera legislativa e mais diretamente associada à dinâmica de interação entre o ativismo político e as esferas executiva, participativa e burocrática do Estado. Nesse intuito, o texto encontra-se estruturado em quatro partes: na primeira, que segue esta breve introdução, apresento a gênese e o itinerário da institucionalização do movimento negro nos anos 1980, do nível estadual ao âmbito federal; na segunda, destaco a rearticulação do ativismo na sociedade civil e nas esferas locais no pós-reforma constitucional; na terceira parte, apresento a abertura de um espaço de mediação socioestatal em nível federal, que esteve diretamente entrelaçada a um processo de maior abertura governamental para as demandas sociais, o que garantiu a inserção da agenda da igualdade racial na esfera estatal; por fim, além de apresentar uma síntese dos achados de pesquisa, aponto para algumas reflexões acerca das complexidades e impasses de uma institucionalização de médio alcance em direção ao Estado, com fraca ou baixa representação de tipo parlamentar.

3 Ver Rios (2009; 2014). 


\section{A trajetória de institucionalização do movimento negro brasileiro}

No que diz respeito à institucionalização de canais de interação socioestatal e a construção de encaixes no Estado, a abertura de mecanismos institucionais para a agenda do movimento negro aconteceu inicialmente no plano estadual, durante a mais recente transição democrática, que deu fim ao regime militar no Brasil. Foi a ligação entre as lideranças negras e a ala progressista do Movimento Democrático Brasileiro (MDB) - logo depois PMDB - que possibilitou, pela primeira vez na história do país, a institucionalização de um espaço de mediação_destinado à agenda da igualdade racial na esfera pública estatal. E isso aconteceu de forma pioneira no estado de São Paulo durante o mandato do democrata cristão André Franco Montoro, vencedor das eleições governamentais em 1982. Eleito com a prerrogativa de assumir as forças sociais que marcaram a luta contra a ditadura militar, Montoro teve, em sua plataforma eleitoral, a rubrica da participação da sociedade civil. Com essas expectativas para a sua gestão, grupos de interesses e movimentos sociais passaram a pressionar o governo em favor de sua participação no poder público.

A proposta de formar um conselho específico da comunidade negra foi inspirada no movimento feminista, que já tinha conquistado um espaço participativo na gestão governamental em 1983. ${ }^{4}$ A conquista das mulheres paulistas serviu de referência para o segmento político negro, que não logrou sua representação política legislativa durante a campanha eleitoral de 1982 e nem conquistou espaço executivo durante a gestão Montoro. ${ }^{5}$ Essa dupla derrota, por assim dizer, forçou as lideranças que ocupavam

4 Refiro-me ao Conselho Estadual da Condição Feminina criado em 1983 no estado de São Paulo. Para mais detalhes, consultar Santos (2006).

5 Para mais detalhes sobre a relação de Tarquínio com o movimento social negro, ver Rios (2016). 
cargos de terceiro escalão no governo e lideranças civis a lutarem por um espaço de voz, visibilidade e maior participação na estrutura estatal. A constituição de um conselho apresentou-se como caminho viável, que não estava inicialmente nos horizontes dos ativistas, porém se tornou uma alternativa frente aos seus dilemas e dificuldades de representação legislativa e, por conseguinte, interferência na condução das ações do Estado. Nas palavras de um ex-conselheiro:

Naquela época as pessoas tinham muito medo de serem cooptadas. E eu tinha a clareza de que era mais uma arena política. O movimento ficou muito desconfiado sobre o que viria a ser aquilo dali. E nós tínhamos de experiência o caso das mulheres. Aproveitamos isso para construir o conselho. Foi o primeiro órgão que nós criamos para combater a discriminação racial e para promover as políticas públicas (Ivair Augusto dos Santos, fita 2B, FGV/RJ).

Fruto da pressão política de grupo minoritário, mas que impunha bandeiras de um movimento social expressivo no processo de transição democrática, o decreto que instituía o Conselho Estadual de Participação e Desenvolvimento da Comunidade Negra foi assinado no dia 12 de maio de 1984. Sua existência pioneira foi alvo de diversos debates, conflitos e avaliações no que se refere à autonomia do movimento social em relação ao Estado e à representação institucional. A despeito desses receios, o conselho da comunidade negra, durante os anos de 1980, agregou boa parte da militância negra paulista e serviu de base para o treinamento dos ativistas e suas lideranças no que toca à dinâmica política da gestão pública. Tratava-se, portanto, da rotinização das relações socioestatais, entendidas aqui como trânsito e circulação de agentes civis na esfera do poder público, gerando as condições para os encaixes institucionais, que, por conseguinte, podem se converter 
em "domínios de agência”, a exemplo do acesso ao poder Executivo e Legislativo, a construção de prioridades de pautas, gerada por meio de encontros formais e informais e a politização da temática racial na gestão pública. ${ }^{6}$ Ademais, a experiência paulista serviu de referência para o surgimento de outros órgãos e mecanismos da mesma natureza em municípios e estados brasileiros.

No plano federal, no entanto, o conselho paulista não logrou tornar-se modelo para a formação de um órgão voltado para as reivindicações da comunidade negra. Diferentemente do Conselho da Condição Feminina, que serviu de base para o Conselho Nacional da Mulher, em 1985 (Santos, 2006), as lideranças negras paulistas não tiveram o mesmo êxito em sua negociação com a cúpula do partido do governo federal. Somente com a maior intensidade do ativismo gerada pela mobilização em prol da Constituinte, na qual o movimento social negro se envolveu diretamente, e com o contexto dos preparativos para o centenário da Abolição - permitindo a nacionalização do ativismo - foi possível, em 1988, o aparecimento do primeiro órgão executivo de cunho federal que passou a funcionar como estrutura de intermediação entre os agentes civis e os governamentais, todavia restrito à esfera da cultura. Tratava-se da criação da Fundação Cultural Palmares (FCP), sediada no Ministério da Cultura, que, até a formação da Secretaria de Políticas de Promoção da Igualdade Racial (Seppir), foi o único órgão executivo federal que possuía vínculos diretos com o movimento negro. Mesmo sob várias críticas dos ativistas, notadamente os de vinculação socialista, defensores do argumento de que as demandas da população negra não poderiam se restringir ao campo cultural, a Fundação Palmares cristalizou-se como um espaço institucionalizado, de interação socioestatal, em que atores coletivos civis e estatais negociam interesses relativos à população negra, seja urbana ou rural.

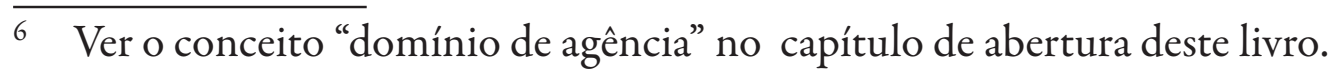


Além dos espaços institucionais, o movimento negro, em articulação com os constituintes alinhados com seus projetos, conquistou alguns dos mais expressivos ganhos constitucionais da história política do Brasil republicano. Embora as constituições anteriores apresentassem a proibição da discriminação racial, foi por meio da intensa interação parlamentar e extraparlamentar em que se viu a articulação amadurecida e supra partidária de deputados e ativistas autodeclarados negros - que, na Carta Magna de 1988, a prática do racismo tornou-se crime inafiançável e imprescritível (artigo quinto, inciso XLII), alterando a Lei Afonso Arinos, de 1951, a qual considerava as ações racistas "meras contravenções penais", que por seu turno poderiam ser reparadas por meio do pagamento de uma quantia irrisória (Silva, 1998). Essa conquista "não apenas tornou mais severa a punição da prática do racismo e da discriminação como também inscreveu um pequeno leque de preceitos, reconhecendo a pluralidade racial brasileira" (Silva, 2002). Por conseguinte, analistas reconhecem que o dispositivo constitucional impulsionou um conjunto de normas e regulamentações jurídicas adotadas posteriormente nas legislações estaduais e municipais, com o fito de coibir práticas discriminatórias, dado o seu caráter proibitivo e repressivo. ${ }^{7}$

Contudo, a ação realmente inédita na reforma constitucional foi a concessão de direitos territoriais e culturais aos quilombolas, novos sujeitos de direitos que emergiam no debate político e acadêmico entre os finais de 1970 e durante toda a década de 1980 . Figura ambígua na retórica do movimento negro, o quilombola foi, para a militância do Sudeste, referência histórica que remetia aos tempos heroicos de Palmares no século XVII; diferentemente do que se passava com a experiência dos ativistas negros do Norte e Nordeste do Brasil, já que estes reconheciam nas zonas e mu-

Além disso, a Lei Federal n.7.716/1989, conhecida como Lei Caó, passou por diversas reformulações durante a década de 1990. Ver Machado, Santos e Ferreira (2015). 
nicípios rurais, relativamente próximos de São Luís e de Belém, comunidades tradicionais descendentes de ex-escravos ou libertos, vivendo em terras comunais, mas sendo constantemente ameaçados pela prática de grilagem, marcante nessas regiões. Por isso, as demandas originais pelo direito quilombola vieram dos estados do Maranhão e do Pará, e foram encaminhadas na Assembleia Nacional Constituinte (ANC) pela deputada Benedita da Silva, uma vez que os respectivos estados não tinham conseguido eleger seus representantes para dar encaminhamento as suas reivindicações. ${ }^{8}$ Essa militância do movimento negro aliada às novas interpretações e ao ativismo da Antropologia brasileira romperia com as visões tradicionais dos comunistas e missionários cristãos, investindo de um novo significado esse segmento populacional do Brasil.?

Assim, toda a mobilização durante a redemocratização, que culminou no direcionamento de demanda por direitos à Assembleia Nacional Constituinte e no Centenário da Abolição, foi decisiva para construir o movimento negro como sujeito político legítimo na esfera pública. Mais do que isso: o tema da injustiça racial inseriu-se na agenda nacional. Com efeito, as conquistas na nova ordem jurídica abriram uma agenda ampla para o ativismo negro, cujas demandas se voltariam para a implementação de políticas e projetos direcionados à população negra rural e urbana, primeiramente na sociedade civil durante a década de 1990. Isso aconteceu por vários fatores, dentre eles: o fechamento do Estado

8 Entrevista de Ivan Teixeira concedida a Flavia Rios nas dependências do Centro de Cultura Negra do Maranhão, em fevereiro de 2010.

9 Para além das ações e iniciativas do movimento negro urbano brasileiro e seus constituintes, é importante lembrar que a virada conceitual da Antropologia, que já vinha mapeando realidades campesinas distintas do que se costumava entrever pelos estudos antropológicos tradicionais, trouxe, em vez do termo camponês, do modelo clássico marxista, novas pesquisas que identificavam comunidades negras rurais, reconhecendo suas peculiaridades e diferenças frente ao complexo rural brasileiro, particularmente, na compreensão do "campesinato de fronteira" (Arruti, 2011). 
brasileiro no âmbito federal para os movimentos sociais logo depois das primeiras eleições presidenciais livres pós-regime militar e o estabelecimento de uma política econômica de Estado mínimo restringindo as políticas sociais e transferindo para a sociedade a responsabilidade de construir "um mundo mais cidadão". Somente com o processo de estabelecimento democrático, liderado por Fernando Henrique Cardoso, que haveria certa permeabilidade para a discussão racial e a temática das desigualdades por cor ganharia mais destaque na esfera nacional.

\section{O pós-transição democrática: reorganização do ativismo $\mathrm{e}$ de suas estratégias}

As conquistas na nova ordem jurídica abriram uma agenda ampla para o ativismo, cujas demandas se voltaram para as ações focalizadas na população negra, o que se deu majoritariamente na sociedade civil, especialmente na primeira metade da década de 1990 (Heringer, 2001). A baixa porosidade da gestão governamental para os movimentos sociais após a reforma da Constituição e a adoção do neoliberalismo como projeto econômico, resultando em conduções políticas menos afeitas à participação dos movimentos sociais na esfera federal, são principais determinantes para essa reconfiguração do ativismo e da interação socioestatal, esta passaria a ser mais intensa nas esferas estaduais e locais. Do mesmo modo, fatores relativos ao ativismo também foram relevantes, como a profissionalização das lideranças, a especialização de suas associações e, sobretudo, a intensificação do apoio internacional das fundações e dos organismos multilaterais (Roland, 2000; Telles, 2003), além da capacidade dos ativistas em negociar com os outros atores da sociedade civil e da experiência adquirida por suas lideranças nas instâncias estaduais e municipais, construídas sob a rubrica da participação política. Tais fatores resultantes da reconfiguração do movimento social definiram a capacidade de ação do ativismo em 
domínios específicos do Estado, delineando as estratégias e o perfil da institucionalização da agenda da igualdade racial no país.

Embora os movimentos sociais tenham conseguido avanços na Reforma Constitucional, com o resultado das eleições de 1989 as expectativas dos ativistas de implementação imediata dos novos direitos constitucionais foram frustradas. Com o fechamento de oportunidade política estatal - ou seja, o esvaziamento dos conselhos e demais espaços de negociação política - durante o governo de Fernando Collor de Mello, os agentes extragovernamentais se reorientaram em termos de estratégia de ação frente à nova conjuntura política nacional. De partida, a posição majoritária das lideranças negras foi a de se colocar em oposição ao governo, o que pode ser verificado nos editoriais de seus jornais e nas declarações públicas das lideranças e da intelectualidade negra. ${ }^{10}$

Nessa conjuntura, as organizaçóes e os militantes apostam em dupla estratégia: trataram de fortalecer seus vínculos com suas bases na sociedade civil, ao mesmo tempo em que se fizeram presentes nas esferas municipais e estaduais, em administrações e governos abertos às demandas dos movimentos sociais. Deve-se notar que as redes de relações construídas nas "trincheiras ideológicas" de oposição ao regime militar foram decisivas para inserção de alguns ativistas em escalões intermediários de governos locais, ou ainda para a negociação de pautas direcionadas à população negra. Foi nesse contexto que surgiram os primeiros programas e órgãos executivos voltados à igualdade racial, a exemplo da Secretaria Extraordinária de Defesa e Promoção das Populações Negras, a Sedepron, criada no segundo mandato do governo Leonel Brizola (PDT), no Rio de Janeiro em $1991 ;{ }^{11}$ da Coordenadoria de Assuntos para a População Negra, a CONE, criada por meio

${ }^{10}$ Como pode ser visto nos seguintes editoriais: "O negro e o Governo Collor: participar da oposição popular" (Jornal da Unegro, fev. 1990); "Plano Collor: miséria e abandono" (Jornal do $M N U$, jan-mar. 1991).

${ }^{11}$ Larkin e Nascimento (2000). 
da lei 11.321/1992, durante o governo de Luiza Erundina (PT); ${ }^{12}$ da Secretaria Municipal para Assuntos da Comunidade Negra em Belo Horizonte, em 1998, durante mandato de Célio de Castro (PSB) $;^{13}$ e da Assessoria de Defesa da Comunidade Negra do município de Santo André, em 2001, na terceira gestão de Celso Daniel (PT). ${ }^{14}$

Por sua vez, os espaços no plano federal que tinham vínculos fortes com as lideranças negras sofreram duras restrições. A Fundação Cultural Palmares (FCP), criada pelo Executivo federal para canalizar demandas no interior do Ministério da Cultura, recebeu fortes pressões políticas e acabou por ser extinta. Sob a alegação de controle dos gastos públicos, o presidente Collor expediu a Medida Provisória de número 151, no dia 15 de março de 1990, dissolvendo várias autarquias públicas, dentre elas a Fundação Palmares. ${ }^{15}$

A política presidencial gerou reação. Criou-se, então, o grupo Palmarino, comissão pró-Fundação Palmares, que foi responsável por pressionar o Congresso Nacional e exigir a emenda de supressão da FCP da lista da medida 151. Um documento foi encaminhado via oposição ao governo Collor e às casas legislativas. $\mathrm{O}$ senador Renan Pinto (PMDB-MG) discursou em defesa da revogação da referida medida, alegando que a FCP era um órgão com apenas três funcionários, sem dotação orçamentária própria e com uma missão significativa para o país, pois se tratava de um espaço criado para uma grande parcela da população. Entre seus argumentos de defesa, cabe salientar a relevância que deu para as lutas negras brasileiras, desde o quilombo dos Palmares, bem como para

12 Ver www.prefeitura.sp.gov.br/cidade/secretarias/igualdade_racial/organizacao/index.php?p=149057. Acesso em: 29 jul. 2015.

13 Depoimento de Diva Moreira concedido a Albert e Pereira em 2008 (FGV/ $\mathrm{RJ})$.

${ }^{14}$ Ver Souza (2013).

15 Jornal Axé, set. 1990. 
o espaço institucional conquistado "pelo movimento negro organizado", destacando a relevância deste último para a construção da democracia brasileira. Se por um lado, o senador posicionou-se em defesa dos interesses das lideranças negras, por outro, valeu-se do sentimento nacionalista, a democracia racial, para expressar suas crenças e atingir os corações e mentes dos senadores. Disse ele em plenário: "Quem não é negro nesse país? Quem não é negro na pele, é negro no sangue; quem não é negro no sangue, é negro na alma”. Para ele, uma das contribuições dos negros ao país foi justamente a construção de nossa democracia, "inclusive a democracia da convivência fraterna". ${ }^{16}$

Elemento comum entre o discurso do senador e do grupo Palmarino foi o argumento demográfico. $\mathrm{O}$ expressivo percentual de pardos e pretos na população brasileira é um dos principais frames $^{17}$ dos ativistas negros: "o negro é maioria". Nesse enquadramento interpretativo, joga-se constantemente com o binômio minoria versus maioria nos discursos políticos. Evidentemente, sendo a minoria para se referir à representação política e a maioria, à proporção de pretos e pardos nas pesquisas censitárias. Cabe destacar ainda que o documento produzido pelo grupo Palmarino traz alguns importantes argumentos sobre a relevância da Fundação Palmares, em especial porque mostra o interesse de manter o espaço institucional, ou seja preservar um canal de interação socioestatal aberto aos interesses e valores da comunidade negra. Segundo os ativistas, o órgão servia para a "eliminação do racismo" e para

${ }_{16}$ Jornal Axé, set. 1990 , p. 23.

${ }^{17}$ Frames são entendidos aqui como esquemas interpretativos redutores da realidade social. $\mathrm{Na}$ ação política, atores recortam e selecionam situações ou experiências entendidas como sendo injustas na economia moral da sociedade e valem-se desse enquadramento para tentar alterar a estrutura social dominante; ver Benford e Snow (2000). Análises de frames foram usadas, por exemplo, por Cott (2000) para entender as disputas dos negros e indígenas, de um lado, e as elites políticas, de outro, no processo constituinte da Colômbia. 
criar um "espaço de representação" em uma "relação direta com o poder central". Assim, no jogo entre a velha retórica da democracia racial, acionada pelos políticos de oposição ao governo, e as novas demandas institucionais dos negros, a Fundação Cultural Palmares não desapareceu, mas foi fragilizada e operou debilmente nos anos Collor.

Da mesma forma, o Conselho Nacional das Mulheres, no qual atuavam importantes lideranças feministas negras, tais como Benedita da Silva, Lélia Gonzalez e Sueli Carneiro, foi esvaziado durante a administração do presidente eleito em 1989, forçando as ativistas a retirarem-se por não verem ali possibilidade efetiva de participação. De modo que todo o aprendizado institucional, o acúmulo de discussão e de iniciativas relativas à questão racial e de gênero, via o conselho federal, foram atrofiados durante o mandato do presidente Collor de Mello. Nessa conjuntura, era preciso reorientação de estratégicas, que não significaria abandono completo das instituições federais conquistadas no processo de democratização, e sim investimentos mais expressivos nas esferas locais e estaduais que tivessem maior abertura política para a agência civil. Esses dois fatores definiram a capacidade de ação do ativismo, que foi determinante para atuação dos agentes em domínios específicos do Estado, delineando as estratégias e o perfil da institucionalização da agenda da igualdade racial no Brasil.

Com efeito, as lideranças negras deslocaram-se para as organizações e iniciativas políticas, culturais e assistenciais no interior da sociedade civil, seja por meio de captação de recursos junto a organismos internacionais (as chamadas "parcerias"), seja ainda pela participação em esferas municipais e estaduais. Foi nesse contexto que proliferaram, por todo país, organizações e ações tendo como 
público-alvo os segmentos populacionais de pretos e pardos, que, aos poucos, tornaram-se "negros e pobres" ou "negros e carentes". ${ }^{18}$

Depoimentos de conselheiras e lideranças, profundamente engajadas com as pautas da igualdade racial e de gênero, representam bem o quadro avaliativo do movimento social frente ao cerramento da estrutura de oportunidades políticas no plano federal. Esse é o caso de Edna Roland que, durante as mobilizações dos anos de 1980, engajou-se nos movimentos sociais feministas e negros, ${ }^{19}$ sendo uma das ativistas fundadoras do Geledés, que se consolidou durante os anos 1990 como uma das organizações mais respeitadas do Brasil. ${ }^{20}$ Essas lideranças enxergaram mais vantagens em atuar nas organizações da sociedade civil do que em permanecer na estrutura do Estado. Nas palavras de Edna Roland:

Com nossa passagem no Conselho da Condição Feminina e no Conselho Nacional dos Direitos da Mulher, nós tínhamos aprendido as práticas administrativas e como se organizam as instituições, as comissões, os grupos de trabalho e tínhamos entrado em contato com certas agências financiadoras. Quando houve o fechamento do Conselho Nacional, Sueli [Carneiro] estava negociando o SOS Racismo entre o Conselho e a OAB. Ela então passa a negociar com a Ford a transferência [do SOS racismo] do Conselho para que fosse uma parceria da $\mathrm{OAB}$, o

18 Os deslizamentos semânticos emergentes durante essa última década marcaram os termos dos discursos pela justiça social, disseminados pelos movimentos sociais, pela mídia e até pelos governos nas proximidades da virada do século.

19 Ver depoimento de Edna Roland no CPDOC/FGV; fita 1, lado B, Rio de Janeiro.

20 O Geledés é chamado também de Instituto da Mulher Negra, e, atualmente, está localizado na Vila Buarque, centro de São Paulo. Como missão, a organização se propóe a lutar contra o racismo e o sexismo. Maiores informações sobre a referida organização podem ser encontradas nas pesquisas de Sebastião (2007), ou mesmo pelo site: http://www.geledes.org.br/. Acesso em: 12 jul. 2015. 
nascente Geledés e, a pedido da Ford, o NEV/USP (Depoimento de Edna Roland, fita 3B, CPDOC/FGV/RJ, 2008).

Nesse novo quadro político nacional, longe de haver uma desmobilização social dos grupos negros, verificam-se mudanças de estratégias, que acarretam maior focalização das demandas sociais, segmentação e diversificação do ativismo político bem como a diferenciação de suas lideranças e organizações. As redes profissionais e políticas foram decisivas para que suas organizações pudessem ganhar credibilidade social num contexto em que, mais do que a legitimidade da reivindicação, passou a contar no jogo político a formação e a especialização dos quadros institucionais civis. ${ }^{21}$ Some-se a isso o empenho das lideranças em atingir os interesses da população negra. Uma das principais estratégias discursivas foi reconverter o negro de minoria política à maioria social e demográfica - a exemplo da campanha censitária de 1990, Não deixe sua cor passar em branco -, rejeitando, assim, a construção de que o Brasil fosse ou viesse a ser um país branco ou mestiço.

Rosana Heringer (2001), ao pesquisar dez capitais brasileiras, apresentou um mapa das iniciativas voltadas para o "combate ao racismo" durante os anos de 1990. Ela mostrou um leque amplo de projetos nas áreas da cultura, da educação, dos direitos humanos, do trabalho, da informação, da legislação e da saúde, entre outras. Desse levantamento, três áreas têm centralidade: direitos humanos e advocacy, trabalho e geração de renda, além da educação. Inspirada no SOS Racismo do Geledés - serviço de assistência jurídica e acompanhamento de vítimas de discriminação racial, ancorando-se na Lei Federal n. 7.716/1989 - advocacy é a forma de atuação política apropriada por outras organizações no país, tendo em vista a criação de jurisprudência para os casos de

${ }^{21}$ Essa discussão foi desenvolvida em minha dissertação de mestrado, intitulada Institucionalização do movimento negro no Brasil contemporâneo (Rios, 2009). 
discriminação por motivos raciais, por representações individuais ou coletivas (Carneiro, 2000). Da mesma forma, as iniciativas voltadas à esfera do trabalho foram geralmente programas de qualificação profissional e de sensibilização de sindicatos e empresas no que toca à alocação de trabalhadores pretos e pardos, a exemplo dos projetos empreendidos pelo Centro de Estudos das Relações de Trabalho e de Desigualdades (Ceert), valendo-se de dispositivos internacionais como a Convenção 111 da Organização Internacional do Trabalho (OIT), a qual estabelece o princípio da não discriminação em matéria de emprego e profissão. Por fim, as ações mais numerosas e extensas no território brasileiro foram as de fins educacionais, em particular, atividades comunitárias voltadas para informação, reforço escolar e, especialmente, cursos preparatórios para os exames vestibulares às universidades. Esses últimos são projetos sociais de forte potencial mobilizatório, destinados à juventude negra "carente" ou "pobre", apresentando-lhes alternativas sociais e novas expectativas de futuro via educação superior. Nessas instituições são gestados os discursos em defesa das ações afirmativas que emergem no Brasil nos anos finais do século XX, tornando-se a linguagem contenciosa (Tarrow, 2013) da agenda por igualdade racial no país. ${ }^{22}$

\section{4. $\mathrm{O}$ antirracismo de Estado}

O tema das ações afirmativas animou polêmica pública no Brasil desde meados da década de 1990, promovendo cisões em campos disciplinares, enfrentamentos públicos entre intelectuais,

${ }_{22}$ O Geledés, por exemplo, em parceria com o Bank Boston organizou um projeto chamado Geração XXI, considerado uma experiência de ações afirmativas de cunho privado e civil voltada para estudantes negros de escolas públicas das periferias de São Paulo. Já o cursinho de Consciência Negra da USP fez a primeira campanha pública em defesa das cotas no ensino superior na cidade de São Paulo. 
políticos e jornalistas, e impulsionando a produção acadêmica sobre o assunto. Entretanto, a proposta de política de inclusão para grupos social e racialmente sub-representados no ensino superior só veio a ter impacto sobre as instituições brasileiras após a III Conferência Mundial contra o Racismo, a Discriminação Racial, a Xenofobia e a Intolerância Correlata, ocorrida na África do Sul em 2001(Telles, 2003; Lima, 2010), quando o ativismo transacional de agências e lideranças negras conseguiu, articulado às autoridades governamentais, o feito inédito de inscrever no plano de Ação de Durban as affirmative actions como forma de enfrentamento das desigualdades vivenciadas pelos afrodescendentes (Saillant, 2014).

Essas resoluções negociadas no plano internacional, associadas às reivindicações no plano doméstico, confluíram decisivamente para os desdobramentos políticos que envolveram o ativismo político, os agentes públicos e governantes na formulação de projetos de reserva de vagas nas universidades brasileiras. Num plano mais amplo, favoreceu a ampliação do debate público sobre o tema das relações raciais. Alguns efeitos mais imediatos desse contexto também podem ser vistos nas iniciativas de institucionalização da agenda de igualdade racial no plano federal no primeiro mandado do governo Lula, em particular na formação de uma secretaria com status de ministério voltada para esse fim.

A Secretaria de Políticas de Promoção da Igualdade Racial da Presidência da República (Seppir) foi criada em um contexto em que agentes políticos civis conseguiram influir na campanha eleitoral e no processo pós-eleitoral de 2002, criando condições para políticas públicas com esse recorte no primeiro mandato do Partido dos Trabalhadores no governo federal. ${ }^{23} \mathrm{~A}$ formação dessa

${ }^{23}$ Essa instância governamental surge, inicialmente, como secretaria especial por meio da medida provisória n. 111, de 21 de março de 2003, depois convertida em Secretaria de Políticas de Promoção da Igualdade Racial, por meio da lei n. 10.678, em 23 de maio de 2003. Assim, a Seppir nasceu diretamente ligada 
secretaria deve ser atribuída a pelo menos dois fatores determinantes: (1) a ascensão da temática racial na esfera federal e internacional sustentada pela rede de ativismo antirracista; (2) a mobilização da militância negra no interior do PT em sua interação com o núcleo de poder do governo, especialmente com a corrente da articulação, o que evidencia o papel da interação socioestatal via partido na esfera do poder político.

Nos objetivos da Seppir, o tema das Ações Afirmativas ganha centralidade. Dos seis objetivos da instituição, três citam tais políticas como prioridade. A título de exemplo, na missão institucional, fala-se em "formular e coordenar a avaliação das políticas públicas afirmativas de promoção da igualdade", ou mesmo "em planejar e coordenar a execução e avaliação do Programa Nacional de Ações Afirmativas". O documento também faz referência ao monitoramento dos acordos e legislações sobre o tema, sendo o objetivo da instituição:

acompanhar a implementação de legislação de ação afirmativa e definição de ações públicas que visem ao cumprimento de acordos, convenções e outros instrumentos congêneres assinados pelo Brasil, nos aspectos relativos à promoção da igualdade e combate à discriminação racial ou étnica (Seppir, 2003).

Com efeito, as políticas de ações afirmativas constituíram o campo de disputa mais significativo do movimento social em sua interação com o Estado na primeira década do século XXI. Curioso é notar que tais políticas não conseguiram ser aprovadas pelas casas legislativas nesse mesmo período. O Estatuto da Igualdade Racial, que tramitou por quase uma década no legislativo, passou por várias reformulações até seu conteúdo sobre a temática perder seu

ao gabinete da Presidência da República, com status de ministério, porém sem dotação orçamentária própria e com o papel de indutora de políticas de promoção da igualdade racial no país. 
conteúdo propositivo. As ações afirmativas, portanto, não conseguiram se estabelecer na agenda pública do Estado via representação legislativa, porque sofreram bastante resistência parlamentar. ${ }^{24}$

No que compete à representação parlamentar, cuja dinâmica depende de processos de autorização eleitoral, movimento social negro encontrou menor permeabilidade, seja para a aprovação de pautas da agenda da igualdade racial, seja em termos dos assentos nas casas legislativas federais. Estudos têm demonstrado a sub-representação de negros no Legislativo ao longo das últimas três décadas (Johnson III, 1998; Paixão, 2008; Rios et al., 2017) e apontam que a baixa representação parlamentar de negros enfrenta tanto as barreiras raciais, explicadas pela cultura política das agremiações partidárias - como os custos econômicos da representação de grupos de estratos populares e sem herança familiar ou redes políticas de elite (Campos e Machado, 2015), mas não contam com desengajamento desse segmento populacional nas candidaturas nem com a rejeição do eleitorado (Bueno et al., 2014). ${ }^{25} \mathrm{No}$ que importa para o argumento da institucionalização da agenda da igualdade racial ou da inserção de seus agentes na esfera pública estatal, a representação parlamentar na forma descritiva ou substantiva contou pouco para o processo aqui analisado: exemplo mais eloquente disso foi a longa tramitação do Estatuto da Igualdade Racial que levou uma década para ser aprovado. ${ }^{26}$

${ }_{24}$ Note-se que as políticas de ações afirmativas tiveram sua legalidade questionada no Supremo Tribunal Federal. Somente em 2010, o STF votou favorável à constitucionalidade desse mecanismo de combate às desigualdades raciais no âmbito do ensino superior.

25 Em seu estudo sobre representação e raça, Campos e Machado (2015) argumentam que, até a inserção oficial do quesito cor nos registros do Tribunal Superior Eleitoral, as pesquisas feitas sobre a representação racial na política institucional basearam-se em informações coletadas nos partidos ou em entrevistas realizadas com os políticos ou mesmo em simulações com base na heteroclassificação por meio das fotos dos candidatos. Ademais, os autores também avançam na explicação das causas da baixa participação de negros no Parlamento.

26 Sobre o processo de tramitação do Estatuto da Igualdade Racial, do projeto apresentado em 2000 ao documento legal aprovado em 2010 por meio da lei n. 
Todavia, políticas de ações afirmativas no ensino superior - uma das principais demandas conquistadas pelo movimento social - foram ganhando corpo nos planos locais e estaduais, especialmente nas burocracias e colegiados das instituições universitárias: uma miríade de ações inclusivas espalhou-se no território nacional, valendo-se majoritariamente da autonomia das universidades. Assim, sob pressão dos movimentos sociais, que atuaram em coalizão nas campanhas tópicas e nacionais pelas reservas de vagas, os processos decisórios em conselhos e burocracias universitárias predominaram em contraste com as decisões das casas legislativas estaduais. ${ }^{27}$ Em sua primeira década de existência, o padrão de ações afirmativas do sistema público brasileiro foi, pois, as cotas desenvolvidas no interior das instituições públicas de terceiro grau, e não uma política de Estado (Guimarães e Rios, 2014).

Somente depois de uma década de vigência das ações afirmativas no Brasil, o governo Dilma Rousseff conseguiu sancionar a chamada Lei 12.711 , conhecida como a lei das cotas. Nessa gestão, tem-se a ampliação das ações afirmativas no ensino superior federal, com a legislação que oferece homogeneidade à miríade de programas universitários, espalhados pelo país afora. Ademais, as perdas sofridas no processo de aprovação do Estatuto da Igualdade Racial foram parcialmente compensadas com a legislação relacionada às políticas de ações afirmativas sancionadas pelo Executivo federal.

\section{Institucionalização à luz do movimento negro: à guisa de conclusão}

O período pós-transição democrática trouxe questões desafiadoras para o estudo dos movimentos sociais no Brasil. A prin-

12.288, e sobre os cortes sofridos nas casas legislativas, ver Oliveira (2013).

$27 \mathrm{Na}$ campanha pelas ações afirmativas, o repertório de interação entre ativismo e burocracias universitárias pode ser melhor flagrado nas análises de caso presentes no livro organizado por Santos (2012). 
cipal delas refere-se à entrada de agentes e de agendas de grupos organizados que se apresentam legitimamente na esfera pública enquanto representantes de segmentos sociais sub-representados na política institucional. Observados numa perspectiva longitudinal, esses agentes buscaram estabelecer alianças estratégicas, articulações que envolveram solidariedade social, autonomização e pluralismo no interior da sociedade civil (Gurza Lavalle e Szwako, 2015). Mais do que isso, ao se analisar as trajetórias dos diversos agentes promotores dos ciclos de contestação, da última ditadura até a democracia, a literatura especializada apresenta o diagnóstico de que grande parte desses movimentos caminhou em direção à institucionalização de suas formas organizativas, bem como de algumas de suas demandas dirigidas ao Estado, o que implicou também a absorção de lideranças civis no âmbito da gestão pública ou das formas de participação e controle públicos. Isso é particularmente notável nos movimentos feminista (Sarti, 2004; Avelar, 2013), negro (Rios, 2009), LGBT (Simões e Facchini, 2009) e de direitos humanos (Carlos, 2014), entre outros.

Contudo, os caminhos em direção à institucionalização não foram unívocos. Os itinerários, o grau de institucionalidade e as formas de interação com o Estado dependeram de vários fatores, dentre os quais destaco alguns flagrantes neste estudo de caso: (1) nível de organização do movimento social; (2) complexidade e densidade das redes sociais e políticas; (3) relação com partidos políticos; (4) articulações internacionais; (5) encaixes institucionais potencialmente produtores de domínios de agência ; (6) abertura governamental para interesses e valores da sociedade civil e; (7) capacidade do ativismo de converter as demandas particulares em reivindicações de interesse público.

Vista assim, a trajetória do ativismo negro parece ser um bom exemplo de institucionalização do período pós-transição, processo entendido aqui em duplo sentido: institucionalização do ator e da demanda social. Trata-se de um movimento social que 
ganhou sua autonomia durante o processo de redemocratização, especialmente entre os períodos do retorno do pluralismo partidário e da reforma constitucional, o que demonstra a relevância de processos democratizantes como janelas de oportunidades políticas para os movimentos sociais (McAdam, 2001; Tarrow, 2008). Esse período caracteriza-se pela formação e fortalecimento de algumas lideranças na incipiente esfera pública, pelo processo de autorização no interior de grupos, pelo nascimento e crescimento de coletivos políticos e pela construção de uma retórica própria de inclusão. ${ }^{28}$

Institucionalizado na esfera pública estatal desde os anos 1980, por meio dos conselhos estaduais, o movimento social ampliou o escopo de sua interação institucionalizada no âmbito federal com a criação da Fundação Cultural Palmares o que, na virada do século, especialmente com a ascensão do Partido dos Trabalhadores à presidência da República, levou à formação da Seppir. Não se pode desconsiderar, entretanto, que foi durante o mandato de Fernando Henrique Cardoso que houve a demonstração mais expressiva do movimento negro, com suas diversas organizações - das mais estritamente políticas às mais culturais -, em Brasília, sinalizando o interesse de que a pauta da igualdade racial viesse a ganhar alguma visibilidade na agenda governamental; em resposta o então presidente acenou positivamente abrindo espaços de diálogo e absorvendo algumas demandas de menor impacto para a opinião pública, de maior teor normativo e de baixo alcance para a redução das desigualdades (Lima, 2010). ${ }^{29}$ Contudo, não

28 Guimarães (2012) apresenta reflexão interessante sobre as retóricas negras de inclusão social nas lutas de agentes negros pela ampliação da cidadania em diferentes períodos históricos.

29 Há pelo menos duas razões para argumentar sobre a relevância do governo Fernando Henrique Cardoso para o surgimento de oportunidades políticas, interpretadas positivamente pelos agentes civis engajados no movimento negro. A primeira delas, largamente utilizada pelos sociólogos, é de que o então presidente era um especialista nas relações raciais e não comungava com 
são as marchas públicas que melhor descrevem o perfil do ativismo negro do fim do século. Ao contrário, nesses anos, o movimento ganha maior grau de organização interna, de modo a transformar muitos coletivos em organizações não governamentais (ONGs), condição que permitiu a sustentação de parte das associações pelo auxílio financeiro de instituições estrangeiras. Aqui, trata-se de uma institucionalização civil, ou seja, da formação sociopolítica que passou por um processo de profissionalização e especialização dos grupos e coletivos, estes tornados associações juridicamente formalizadas.

$\mathrm{Na}$ sequência, percebe-se uma nova inflexão no movimento negro, principalmente porque se expandiram os espaços de atuação do ativismo em direção ao Estado mediante a construção de encaixes institucionais; parte expressiva de suas lideranças tornou-se mediadora do movimento social frente ao poder político durante os governos com maior porosidade para as demandas vindas da sociedade organizada, o que foi verificado nas administrações federais, sob o comando do Partido dos Trabalhadores. Isso é particularmente notável na Secretaria de Políticas de Promoção da Igualdade Racial (Seppir), durante seus anos de formação e consolidação institucional, correspondentes ao período em análise. De 2003 a 2016, no que se refere à ocupação de cargos enquanto encaixes institucionais, a referida secretaria passou pelo comando de cinco ministros, sendo todos, em maior ou menor grau, vinculados às redes de ativismo negro ou de mulheres negras.

Ao que parece, a institucionalização da agenda da igualdade racial no Brasil está menos relacionada à representação eleitoral-

o ideal autoritário de democracia racial, defendido pelos antigos governos, especialmente os militares. O segundo argumento, menos conhecido pela literatura, é de que parte das lideranças civis negras que estiveram na formação do conselho da comunidade negra do Estado de São Paulo estavam estreitamente ligada à base política de FHC durante suas campanhas eleitorais sob a sigla do $(\mathrm{P}) \mathrm{MDB}$. 
mente autorizada na esfera legislativa e mais diretamente associada à dinâmica de interação entre o ativismo político e as esferas executiva e burocrática do Estado. Tal institucionalização deve-se, em partes, à progressiva profissionalização dos militantes, à especialização do ativismo, à formalização das organizações civis, à ampliação de redes políticas nos planos nacional e internacional, à aproximação dos partidos políticos, ao treinamento de lideranças nos espaços participativos e executivos do aparato estatal, resultando na cristalização de encaixes institucionais. Essa configuração tomou forma nos fins anos de 1980, alterando decisivamente as características mais comunitárias e voluntaristas do ativismo político desenvolvido durante a ditadura militar e nos anos da transição democrática.

No início do século XXI, observa-se maior intensidade na interação do ativismo em relação ao Estado, em particular, as lideranças negras passam a acessar, com maior regularidade, os espaços nomeados participativos e as esferas decisórias estatais. Dois efeitos mais expressivos desse processo de institucionalização são: (1) a incorporação de uma das principais reivindicações do movimento negro no combate às desigualdades raciais, ou seja, as ações afirmativas; (2) e a constituição de um organismo executivo federal direcionado à equidade racial, cuja representação passou por critérios de autorização do ativismo negro. Outra novidade é que o movimento social, que durante os anos de 1990 se sustentava economicamente por meio de instituições religiosas e fundações privadas, notadamente as instituiçõos estrangeiras, passa a ter suas fontes de recursos mais diretamente atreladas ao Estado. Essa interação entre o movimento negro e o Estado também gerou consequências complexas no interior do ativismo político, como a maior tensão entre lideranças mais próximas do poder público e as lideranças com maior enraizamento civil, que querem manter certa distância governamental com o fito de garantir um espaço de liberdade para expressar opiniões críticas à condução das políticas 
ou ações públicas, especialmente àquelas - a exemplo da segurança pública - que têm impactos negativos para segmentos populacionais pretos e pardos.

Em síntese, as reflexões desenvolvidas nesse texto sugerem que o estudo do movimento negro no Brasil não pode vir desacompanhado de um quadro mais abrangente da mobilização política brasileira iniciada no processo de contestação da ditadura militar até a reconfiguração dos movimentos sociais no período de pós-transição democrática. Noutra direção, é possível sugerir que as demandas que articulam a necessidade de igualdade racial no Brasil contemporâneo estão intimamente relacionadas ao desempenho de agentes institucionalizados em estruturas de mediação política no interior do Estado e nas demais interações socioestatais em nível meso, estabelecidas na relação com gestões públicas mais porosas às demandas da sociedade civil, configurando-se, portanto, em institucionalização de médio alcance composta por encaixes institucionais.

Por fim, a institucionalização da agenda relativa à igualdade racial no Brasil dependeu estrategicamente de organismos executivos e participativos e sua capacidade de promoção e indução de políticas públicas - mantidos por meio de interação socioestatal entre agentes públicos e ativistas dos movimentos sociais, especialmente no contexto de pós-transição democrática. Assim, a mediação institucionalizada na esfera estatal, bem como a retroalimentação das organizações civis gerou uma interdependência típica dos tempos em que a democracia institucional foi fortemente tensionada a absorver interesses e valores de agentes civis vinculados aos movimentos sociais, muitos dos quais envoltos em mantos de legitimidade costurados nos processos de maior democratização do país. 


\section{REFERÊNCIAS}

AVELAR, Lucia. Movimentos, redes, feminismo de Estado: a representação extraparlamentar das mulheres brasileiras. Cadernos Adenauer, 2013, v. 14, 2013, n. 3, pp. 71-87.

ARRUTI, José M. Diferenciar, redistribuir, reconhecer: ensaio de atualização dos debates sobre terra e educação para quilombos. Cadernos de Campo, 2011, n. 20, pp. 295-303.

BENFORD, Robert; SNOW, David. Framing Processes and Social Movements. Annual Review of Sociology, 2000, n. 26, pp. 611-639.

BUENO, Natália; DUNNING, Thad. Race, Resources, and Representation: Evidence from Brazilian Politicians. Social Science Research Network. 2014. Disponível em: <https://ssrn.com/abstract=2498662>.

CAMPOS, Luiz Augusto; MACHADO, Carlos. A cor dos eleitos: determinantes da sub-representação política dos não brancos no Brasil. Revista Brasileira de Ciência Politica, 2015, n. 16, pp. 121-151.

CARLOS, Euzeneia. Mudanças e continuidades no movimento de direitos humanos: padrões organizacionais, relacionais e discursivos. Opinião Pública, 2014, v. 20, n. 3, pp. 450-479.

CARNEIRO, Suely. Estratégias legais para promover a justiça social. In: Guimarães, Antonio et al. (Ed.) Tirando a máscara. São Paulo: Paz e Terra, 2000.

COTT, Donna Lee van. The Friendly Liquidation of the Past: The Politics of Diversity in Latin America. Pittsburgh, PA: University of Pittsburgh Press, 2000.

DAFLON, Verônica; FERES, João; CAMPOS, Luiz Augusto. Ações afirmativas raciais no ensino superior público: um panorama analítico. Cadernos de Pesquisa, 2013, v. 43, n. 148, pp. 302-327.

GONZALEZ, Lélia. O movimento negro na última década. In: Gonzalez, Lélia; Hasenbalg, Carlos (Ed.). Lugar de negro. Rio de Janeiro: Marco Zero, 1982. 
GUIMARÃES, Antônio S. A questão racial na política brasileira. Tempo Social, 2001, v. 13, n. 2, pp.121-142.

GUIMARÃES, Antônio S. Cidadania e retóricas negras de inclusão. Lua Nova, 2012, n. 85, pp. 13-40.

GUIMARÃES, Antônio Sérgio; RIOS, Flavia. Cotas nas universidades públicas. Afro-Ásia, 2014, n. 50, pp. 251-256.

GURZA LAVALLE, Adrian; SZWAKO, José. Sociedade civil, Estado e autonomia: argumentos, contra-argumentos e avanços no debate. Opinião Pública, 2015, v. 21, pp. 157-187.

HANCHARD, Michael. Orpheus and Power: The Movimento Negro of Rio de Janeiro and São Paulo. Princeton: Princeton University Press, 1994.

HANCHARD, Michael. Orfeu e poder: movimento negro no Rio e Sáo Paulo. Rio de Janeiro: EdUERJ, 2001.

HERINGER, Rosana. Mapeamento de ações e discursos de combate às desigualdades raciais no Brasil. Estudos Afro-Asiáticos, 2001, ano 23, n. 2, pp. $1-43$.

HOFBAUER, Andreas. Ações afirmativas e o debate sobre o racismo no Brasil. Lua Nova, 2006, v. 68, pp. 9-56.

JACCOUD, Luciana; BEGHIN, Nathalie. Desigualdades raciais no Brasil: um balanço da intervenção governamental. Brasília: IPEA, 2002.

JOHNSON III, Ollie A. Racial Representation and Brazilian Politics: Black Members of the National Congress, 1983-1999. Journal of Interamerican Studies and World Affairs, 1998, v. 40, n. 4, pp. 97-118.

LIMA, Márcia. Desigualdades raciais e políticas públicas. Novos Estudos Cebrap, 2010, n. 87, pp. 77-95.

MACHADO, Marta; SANTOS, Natália; FERREIRA, Carolina. Legislação antirracista punitiva no Brasil: uma aproximação à aplicação do direito pelos tribunais de justiça brasileiros. Revista de Estudos Empíricos em Direito, 2015, v. 2, n. 1, pp. 60-92. 
MENEGUELLO, Rachel; MANO, Maíra; GORSKI, Caroline. Alguns condicionantes do déficit representativo de mulheres e negros na política. In: Meneguello et al. (Ed.). Mulheres e negros na politica: estudo exploratório sobre o desempenho eleitoral em quatro estados brasileiros. Campinas: Centro de Estudos de Opinião Pública, 2012.

OLIVEIRA, Sidney. O estatuto da igualdade racial. São Paulo. Selo Negro, 2013.

PAIXÃO, Marcelo; CARVANO, Luiz (Org.). Relatório anual das desigualdades raciais, 2007-2008. Rio de Janeiro: Garamond, 2008.

PHILLIPS, Anne. De uma política de ideia a uma política de presença. Estudos Feministas, 2001, ano 9, pp. 268-290.

RANGEL, Patrícia. Movimentos feministas e direitos das mulheres. Tese (Doutorado em Ciência Política) - Universidade de Brasília, Brasília, 2012.

RIBEIRO, Matilde. Institucionalização das politicas de promoção da igualdade racial no Brasil: percursos e estratégias, 1986-2010. Tese (Doutorado em Serviço Social) - Pontifícia Universidade Católica de São Paulo, São Paulo, 2013.

RIOS, Flavia. A institucionalização do movimento negro no Brasil contemporâneo. Dissertação (Mestrado em Sociologia) - Universidade de São Paulo, São Paulo, 2009.

RIOS, Flavia. O protesto negro no Brasil contemporâneo. Lua Nova, 2012, n. 85, pp. 41-79.

RIOS, Flavia. Elite politica negra no Brasil: relação entre movimento social, partidos politicos e Estado. Tese (Doutorado em Sociologia) - Universidade de São Paulo, São Paulo, 2014.

RIOS, Flavia. Esmeraldo Tarquínio (1927-1982). Dictionary of Caribbean and Afro-Latin American Biography. v. 6. Oxford: Oxford University Press, 2016, pp. 156-157.

RIOS, Flavia; PEREIRA, Ana Cláudia; RANGEL, Patrícia. Paradoxo da igualdade: gênero, raça e democracia. Ciência e Cultura, 2017, v. 69, n. 1, pp. 39-44. 
SAILLANT, Francine. Le mouvement noir au Brésil, 2000-2010: réparations, droits et citoyenneté. Paris: L'Harmattan, 2014.

SANTOS, Fabiano; SZWAKO, José. Da ruptura à reconstrução democrática no Brasil. Saúde em Debate, 2016, v. 40, n.esp., pp.114-121.

SANTOS, Ivair Augusto. O movimento negro e o Estado (1983-1987). São Paulo: Prefeitura de São Paulo, 2006.

SANTOS, Jocélio Teles (Org.). Cotas nas universidades: análise dos processos de decisão. Salvador: Centro de Estudos Afro-Orientais da UFBA, 2012.

SANTOS, Yumi G. A implementação dos órgãos governamentais de gênero no Brasil e o papel do movimento feminista: o caso do Conselho Estadual da Condição Feminina de São Paulo. Cadernos Pagu, 2006, n. 27, pp. 401-426.

SARTI, Cynthia Andersen. O feminismo brasileiro desde os anos 1970: revisitando uma trajetória. Estudos Feministas, 2004, v. 12, n. 2, pp. 35-50.

SILVA JR., Hédio. Antirracismo: coletânea de leis brasileiras. São Paulo: Oliveira Mendes, 1994.

SILVA JR., Hédio. Direito de igualdade racial. São Paulo: Juarez de Oliveira, 2002.

SIMÕEE, Júlio Assis; FACCHINI, Regina. Na trilha do arco-íris: do movimento homossexual ao LGBT. São Paulo: Editora Fundação Perseu Abramo, 2009.

SOUZA, Fernando Luiz Monteiro. Ativismo de mulheres negras e politicas de promoção da igualdade racial. Tese (Doutorado em Sociologia) - Universidade de São Paulo, São Paulo, 2013.

TARROW, Sidney. The Language of Contention. Cambridge: Cambrige University Press, 2013.

TELLES, Edward. Racismo à brasileira. Rio de Janeiro: Relume-Dumará, 2003. 



\section{Capítulo 6}

\section{FEMinismos, MOVIMENTOS DE MULHERES E AS POLÍTICAS DE SAÚDE PARA AS MULHERES}

Layla Pedreira de Carvalho

\section{Introdução}

O Estado coloca-se de maneira perene no horizonte da mobilização feminista, seja no âmbito dos movimentos sociais, seja nos meios acadêmicos. $\mathrm{O}$ questionamento da participação no Estado dada a sua estrutura intrinsecamente patriarcal é um paradoxo que as teóricas políticas feministas constantemente revisitam. Isso é consequência do reconhecimento de que o Estado produz e reproduz desigualdades ao mesmo tempo em que é uma arena de possibilidade de mudança da estrutura de poder nas sociedades. Além disso, a arena da política formal representa o espaço público por excelência, espaço em que as feministas planteiam a presença de mulheres, de suas agendas e histórias. Para as ativistas, o Estado é um ator igualmente paradoxal, na medida em que possui os meios de controle dos corpos e das vidas ao mesmo tempo em que pode atuar na garantia de direitos e de alguns avanços para a agenda dos movimentos de mulheres.

$\mathrm{Na}$ perspectiva do movimento feminista no Brasil, a relação com Estado é ainda mais marcante, sobretudo considerando a reestruturação do movimento a partir de 1975 . O reconhecimento do papel do Estado e de instituições nacionais e internacionais tem lugar de destaque na reorganização de grupos feministas institucionalizados. O Centro da Mulher Brasileira, por exemplo, foi 
criado com apoio das Nações Unidas, em 1975, durante a vigência do regime ditatorial no país. É também ainda durante os anos de exceção, nos estertores da ditadura civil-militar, que alguns dos esforços iniciais de consolidação de políticas públicas para as mulheres são engendrados. Assim, em 1982, há a criação do Conselho da Condição Feminina em São Paulo, com apoio das feministas que atuavam no PMDB, partido que governava o estado no período. Em 1984, é lançado o Programa de Atenção Integral à Saúde da Mulher (PAISM), pelo Ministério da Saúde (MS), fruto do trabalho de feministas nas carreiras do MS. Em 1985, como resultado do processo de negociação durante a montagem da campanha de Tancredo Neves, cria-se o Conselho Nacional dos Direitos da Mulher (CNDM), primeira instituição de política para mulheres em nível federal. É também na década de 1980 que são criadas as Delegacias Especializadas de Atendimento à Mulher (DEAMs) e que a Assembleia Constituinte de 1986 contempla mudanças importantes no entendimento dos direitos de mulheres e homens na Constituição de 1988.

O objetivo deste capítulo é tratar de um aspecto específico da relação entre Estado e o movimento feminista durante os anos 2000 e como os encaixes socioestatais, as trocas entre as ativistas dos movimentos de mulheres e as equipes do MS atuaram na alteração das políticas para as mulheres durante 2004 e 2011. Fazemos isso por meio da análise das reações de três redes do movimento de saúde para as mulheres - a Rede Feminista de Saúde (RFS), a Rede pela Humanização do Parto e Nascimento (ReHuNa) e a Articulação de Mulheres Negras Brasileiras (AMNB) - frente à atuação do Executivo federal em duas políticas públicas voltadas para a saúde das mulheres elaboradas durante os anos 2000: a Política Nacional de Atenção Integral à Saúde da Mulher (PNAISM) e o Programa Rede Cegonha. Nesse sentido, utilizamos a noção de encaixes socioestatais para responder à seguinte pergunta: Em que medida é a interação entre instituições estatais e 
ativistas/grupos organizados que modifica as políticas de saúde do governo federal durante os anos 2000?

Para responder a essa pergunta com base na atuação das redes de ativismo em torno da saúde das mulheres, utilizamos entrevistas, declarações e documentos de líderes de cada uma das redes escolhidas. Essas declarações e documentos foram extraídos dos sites das organizações de que as ativistas são parte e de entrevistas concedidas a veículos de comunicação da mídia digital e convencional. A escolha de tais registros justifica-se pelo fato de que buscamos as reações imediatas das redes às políticas apresentadas, sobretudo durante o ano de 2011, momento em que a política mais controversa - o Rede Cegonha - foi lançada.

As redes de ativismo apresentam, cada uma delas, trajetórias específicas. A RFS e ReHuNa foram criadas no início da década de 1990 por profissionais de saúde e por organizações já envolvidas na defesa dos direitos reprodutivos. São organizações com funcionamento em todos os estados da federação, com pautas diferentes entre si no que tange à especificidade de sua defesa da estrutura das políticas de saúde para as mulheres. Enquanto a RFS possui uma pauta que se baseia na noção de integralidade da abordagem da saúde da mulher, a ReHuNa foca sua atuação na promoção do parto e nascimento humanizados. A AMNB é a mais recente entre as três redes criadas. Foi fundada em 2000, por organizações do movimento de mulheres negras, como preparação para a Conferência de Durban. Sua pauta é a defesa das mulheres negras, pelo fim do racismo, da opressão e das políticas eugenistas.

O texto está organizado em três seções além desta introdução e a conclusão. $\mathrm{Na}$ segunda seção, apresentaremos alguns dos debates em torno do papel do Estado na teoria feminista e na abordagem dos direitos sexuais e reprodutivos. $\mathrm{Na}$ terceira seção, apresentaremos as duas redes de saúde das mulheres desde a sua formação na década de 1990 até os desdobramentos recentes de sua atuação política junto ao Estado. Na quarta seção, analisare- 
mos as reações das três redes em relação às duas políticas, de forma a entender quais são os interesses e as agendas que estão vigorando na elaboração dos programas em foco.

\section{As feministas e o Estado}

Grosso modo, podemos abordar a relação entre as feministas e o Estado em dois grandes grupos. O primeiro compreende aquelas que percebem o Estado como um mal, que tende a reproduzir as desigualdades de gênero porque se forma com base em tais desigualdades. $\mathrm{O}$ segundo propõe a possibilidade de uma interação possível entre os movimentos organizados de mulheres e o Estado, com reais chances de mudanças do status de poder das mulheres por meio da atuação autóctone de feministas nas carreiras do Estado. Neste último grupo, é importante ressaltar que esse debate comumente se confunde com a questão da 'cooptação', mas não é esse o destaque que damos à relação entre o Estado e os movimentos sociais. Pensamos nessa relação como a possibilidade de estabelecer canais de diálogo, os quais permitam mudanças nas políticas públicas adotadas pelo Estado. Apresentamos exemplos de cada um deles e em seguida propomos a nossa abordagem em relação às políticas apresentadas.

Catherine Mackinnon, no livro Toward a Feminist Theory of the State, defende que a definição feminista de Estado deveria passar necessariamente por um debate sobre a questão da sexualidade, na medida em que o Estado se produz na lógica intrínseca à sexualidade que subordina as mulheres em favor do direito e do desejo dos homens. A consequência disso é que leis específicas, sobre estupro e aborto, por exemplo, explicitam uma racionale masculinizada, que tende a proteger privilégios masculinos.

Para além da opressão masculina, considerando as políticas de eugenia e o papel dos Estados nacionais para o desenvolvimento do racismo e de políticas racializadas, o feminismo negro e o femi- 
nismo decolonial também ressaltam o caráter o duvidoso da atuação estatal e a necessidade da constante vigilância quanto a ações e políticas desenvolvidas. Nesse sentido, Dorothy Roberts (1997) demonstra o processo de criminalização da gravidez de mulheres negras e do branqueamento das políticas de welfare. Por sua vez, Rita Laura Segato (2012) sugere que os remédios oferecidos pelo Estado são necessários para curar as doenças que a própria existência do Estado cria.

Sonia Alvarez (1990; 1994), ao analisar a relação entre as feministas no Brasil e o Estado no período de redemocratização, apresenta alguns dilemas que marcam a transição entre o posicionamento de um distanciamento completo ao Estado e a apologia ao trabalho das femocratas nas burocracias estatais:

Durante os anos 1980, o Estado passou do que denominei como 'o pior inimigo das mulheres' a representar-se como o 'melhor amigo das mulheres', apropriando-se de elementos seletivos dos discursos e reivindicações feministas históricas. Ao responder às feministas militantes de partidos de oposição, os governos converteram muitos temas básicos da agenda política feminista em propostas de políticas públicas (Alvarez, 1994, pp. 279-280; tradução livre). ${ }^{1}$

Mas à medida que a política de transição se assentava, e o Brasil voltava à "política de costume", o Estado brasileiro

1 No original: "Durante los años ochenta, el Estado pasó de ser lo que he denominado 'el peor enemigo de las mujeres' a representarse a si mismo como 'el mejor amigo de las mujeres' apropiándose de elementos selectivos de los discursos y reivindicaciones feministas históricos. $\mathrm{Al}$ responder a las feministas militantes en los partidos de oposición, los gobiernos convirtieron muchos temas básicos de la agenda política feminista en propuestas de políticas públicas. [...]. Pero a medida que se asentaba la política de transición y el Brasil volvía a la 'política de costumbre', el Estado brasileño empezó a parecerse cada vez menos al 'mejor amigo de las mujeres' y mucho más a un 'amigo alejado'" (Alvarez, 1994, p. 279280). 
começou a parecer-se cada vez menos ao "melhor amigo das mulheres" e muito mais a um "amigo distanciado" (Alvarez, 1994, pp. 279-280).

Apesar de aproximações e distanciamentos, Alvarez aponta que durante o período de redemocratização, as feministas no Brasil perceberam que o Estado não era um monólito, e que, com a devida intervenção, as políticas públicas podiam ser influenciadas por uma agenda feminista (1990, p. 196). Mala Htun (2001) argumenta no mesmo sentido, ressaltando a importância das alianças conjunturais entre os governos e as ativistas para a aprovação de políticas que reflitam as demandas feministas no contexto da redemocratização em países da América do Sul. ${ }^{2}$

Ressaltando o caráter construtivo da relação entre os feminismos e o Estado, destacam-se mais recentemente as teóricas do feminismo de Estado, uma abordagem conceitual e metodológica (Lovenduski, 2005; Mazur e McBride, 2008) desenvolvida originalmente nos países nórdicos no início da década de $1980 .^{3} \mathrm{~A}$ pergunta principal dessas pesquisadoras é: como e em quais circunstâncias as agências de politicas para as mulheres (APMs) ampliaram o impacto dos movimentos feministas na representação politica das mulheres? (Lovenduski, 2005, p. 5). A representação é considerada tanto no número de mulheres compondo os governos (descritiva) quanto das temáticas tratadas pelas APMS (substantiva). ${ }^{4} \mathrm{O}$ feminismo de Estado pode ser então definido como ações estatais promovidas por mulheres burocratas voltadas para a equidade de

2 A autora compara a formulação de políticas públicas sobre aborto, divórcio e família durante os períodos ditatoriais e democráticos na Argentina, no Brasil e no Chile na segunda metade do século XX.

3 Desde então foi ampliado por meio de pesquisas individuais e por um projeto de pesquisa desenvolvido entre 1995 e 2012, a Research Network on Gender Politics and the State (RNGS).

4 Lovenduski (2005) apresenta a definição de representação feita por Hannah Pitkin para definir as dimensões da representação com as quais as pesquisadoras trabalham nesse projeto sobre o feminismo de Estado. 
gênero, de acordo com premissas e princípios do movimento de mulheres e feminista.

Atualmente, o feminismo de Estado é um conceito em disputa acerca da relação entre Estados e movimentos sociais (Matos e Paradis, 2013). Particularmente na América Latina, dada a dinâmica particular entre esses dois atores - de maior proximidade e interação -, novas pesquisas têm sido realizadas buscando compreender a dinâmica produzida pela participação de feministas na burocracia estatal, seja por meio de atuação junto às agências de políticas para as mulheres (Fernós, 2010), seja por meio da proposta de políticas públicas em áreas tradicionais da gestão pública por meio da institucionalização dos debates de gênero (Guzmán, 2001), o que foi promovido como mainstreaming de gênero desde a Conferência de Beijing, em 1995. O termo mainstreaming foi traduzido como tranversalização de gênero das políticas públicas no Brasil (Bandeira, 2005).

A transversalização de gênero implicaria a consideração das desigualdades de gênero em todas as áreas da vida social e das políticas públicas, conforme previsto na Declaração e no Plano de Ação de Beijing (Bandeira, 2005; Sardenberg, 2008). Em grande medida está relacionada às práticas de governo, uma vez que, de acordo com Bandeira (2010, p. 5), seu uso "garantiria uma ação integrada e sustentável entre as diversas instâncias governamentais e, consequentemente, o aumento da eficácia das políticas públicas, assegurando uma governabilidade mais democrática e inclusiva em relação às mulheres".

$\mathrm{Na}$ abordagem do feminismo de Estado, o impacto do movimento de mulheres nas políticas é classificado de acordo com a resposta a duas perguntas, que dizem respeito à representação substantiva e descritiva, respectivamente: os objetivos das políticas e dos movimentos de mulheres e feministas coincidem? Há mulheres ou grupos de mulheres envolvidos no processo de elaboração das políticas? Com essas perguntas, as analistas do feminismo 
de Estado buscam saber se as políticas incorporaram em seus desenhos e prioridades as demandas dos movimentos de mulheres (Mazur e McBride, 2008). Esse modelo conseguiu resultados interessantes para os países que pesquisou, podendo demonstrar que durante períodos de reestruturação de políticas, a presença de APMs significa potenciais fortes de que as políticas adotadas contemplem representação substantiva e descritiva de mulheres.

No entanto, o feminismo de Estado apresenta alguns desafios para sua observação em países latino-americanos. Em primeiro lugar, a sua base de definição são países do Norte global, o que traz elementos muito particulares de definição das políticas observadas e dos sistemas políticos em que elas são adotadas: democracias consolidadas e participação histórica da sociedade civil na elaboração das políticas. Por exemplo, na área de saúde, como veremos adiante, o Programa de Atenção Integral à Saúde da Mulher e a área técnica de saúde da mulher foram criados durante o período ditatorial, sem interferência dos movimentos feministas ou sem intermediação da sociedade civil, o que impossibilita a resposta às perguntas do modelo. Em segundo lugar, a aplicação do modelo depende da existência de uma APM formal para que se analise a existência de abordagem feminista em determinada política, impossibilitando a aplicação do modelo para arranjos institucionais que fujam à definição mais ampla de relação entre demandas do movimento e o Estado. Finalmente, o modelo foi aplicado para analisar políticas de renovação amplas em setores gerais e não para analisar políticas específicas, como a que pretendemos analisar neste capítulo. Apesar dessas limitações, o modelo de feminismo de Estado apresenta reflexões importantes, que serão incorporadas no modelo de análise que propomos neste capítulo e que serão apresentadas em breve nesta seção.

Mais recentemente, Rebecca Abers e Luciana Tatagiba propõem a análise do ativismo institucional, definido para "descrever o que as pessoas fazem quando assumem posições de trabalho nas 
burocracias governamentais com o objetivo de avançar as agendas políticas ou projetos dos movimentos sociais" (2014, p. 2; tradução livre). ${ }^{5}$ As autoras analisam a Área Técnica de Saúde da Mulher e a atuação das ativistas que trabalham como burocratas na tentativa de implementação das medidas previstas pelo Rede Cegonha. As autoras ressaltam o silêncio da teoria de movimentos sociais, particularmente a teoria da contentious politics, quanto à falta de consideração da presença de ativistas dentro da burocracia estatal. Abers e Tatagiba ressaltam as dificuldades das ativistas em fazer avançar suas agendas dentro da burocracia estatal seja por obstáculos decorrentes da própria atividade burocrática - como os prazos e os ritos - seja pela dificuldade que os temas por elas tratados suscitam, o que impede que resultados de curto prazo sejam percebidos.

Ao adotar os conceitos de encaixes socioestatais e institucionalização intermediária nos é possível lidar com as diferentes abordagens da relação entre Estado e movimentos de mulheres. Diante do apanhado que fizemos, pudemos perceber que diferentemente do que propõe o modelo de feminismo de Estado, por exemplo, nem sempre há participação formal de ativistas nas APMs, porque muitas vezes as APMs não existem e o que se tem são alianças ou confrontações conjecturais para a elaboração ou modificação de políticas propostas. Também, como argumenta Alvarez (1994), quando as APMs existem, elas podem ser reorientadas e distanciar-se das demandas do movimento de mulheres e feminista, como aconteceu em São Paulo durante o governo Orestes Quércia, no final da década de 1980.

Dessa forma, adotamos os encaixes socioestatais como configurações de interação entre burocratas e a estrutura gover-

5 No original: "We use the term institutional activism to describe what people are doing when they take jobs in government bureaucracies with the purpose of advancing the political agendas or projects proposed by social movements" (Abers e Tatagiba, 2014, p. 2). 
namental com ativistas, destacando a atuação dos movimentos de mulheres e feministas nas políticas de saúde. Tais encaixes funcionam tanto no que diz respeito à presença das ativistas dentro do Estado, atuando como burocratas no desenho de políticas públicas (perspectiva horizontal) quanto no encontro entre esferas políticas de atuação (perspectiva vertical), em que os movimentos e organizações da sociedade civil têm o Estado como alvo de suas demandas e críticas. Assim, os encaixes são entendidos como espaços de atuação de ativistas dentro e fora do corpo estatal, tendo como ênfase a produção de resultados na atuação do Estado, seja pela construção de instrumentos de políticas, seja voltando-se a uma lógica de conflito e cooperação superpostas, expressa via críticas e proposição de alteração incremental de políticas tidas como retrógradas, por exemplo.

Na perspectiva horizontal, a presença das ativistas nas carreiras do Estado é voltada para a construção e inclusão da perspectiva de gênero ou, mais amplamente, de demandas dos movimentos de mulheres e feministas nas políticas públicas, e tem caráter instrumental, de conformação de instrumentos de politicas públicas. Essa interação provoca alterações de duplo sentido (Diniz, 2012). Por um lado, tende a produzir alterações nas políticas públicas, aproximando-as das demandas do grupo que compõem a área em que a política é elaborada. Por outro, altera a atuação dos movimentos sociais e das organizações da sociedade civil dentro do Estado de diferentes maneiras: de uma crítica sistemática e apego a determinadas demandas que podem levar ao ostracismo do grupo a uma atuação que tenda a buscar modificações na política proposta, independentemente da avaliação inicial da política, pelo local institucional que as ativistas possuem dentro do Estado. Com base nesta última dinâmica, uma política entendida inicialmente como ruim pelas ativistas pode ser reinterpretada sem que se mudem as principais características de tal política, na medida em que as 
ativistas também precisam legitimar o trabalho que têm feito dentro do MS ou das áreas da política formal de que são parte.

$\mathrm{Na}$ altimetria dos encaixes, a perspectiva vertical da interação sócio-estatal, focada nos dominios de agência, também é parte da interação entre os movimentos feministas e de mulheres com o Ministério da Saúde. No caso que analisamos neste capítulo, a atuação separada e em níveis diferentes entre as ativistas e o Estado no que tange às políticas de saúde acontece no momento em que críticas precisam ser endereçadas de maneira mais enfática às políticas enunciadas pelo MS. Ao abdicar da lógica horizontal engendrada por meio do processo de construção dos instrumentos de políticas públicas e assumir a hierarquia de Estado e impor uma política pública sem prévia negociação, o MS provoca as ativistas a retornarem à posição de conflito e apontarem as falhas das políticas propostas - deixando explícitas as diferentes áreas de atuação do movimento e do Estado. ${ }^{6}$

\section{Três redes discutindo as políticas de saúde para as mulheres}

A RFS e a ReHuNa, voltadas para a promoção e defesa dos direitos sexuais e dos direitos reprodutivos, são fundadas no início da década de 1990. Elas nascem no esteio da abertura democrática, unindo militantes em torno das demandas das mulheres e englobando organizações já ativas na defesa de políticas de saúde para as mulheres. Essas redes apresentam muitas semelhanças entre si, sobretudo quanto à organização, formas de atuação e filiação, mas as diferenças na abordagem das políticas de saúde tornam-se fun-

\footnotetext{
6 Importante ressaltar que não necessariamente a relação vertical dos encaixes implica conflito na medida em que as organizações da sociedade civil podem, dentro de sua área de atuação, cooperar com o Estado, por exemplo, no processo de implementação de políticas públicas em escala local. Exemplo desse tipo de cooperação na formação de profissionais de saúde dentro dos programas de humanização que é feito por organizações de mulheres.
} 
damentais para entender as dinâmicas recentes entre as redes e as políticas federais de saúde para as mulheres. Exatamente no ano 2000 é criada a AMNB. Sua criação tinha como objetivo garantir a preparação e a presença das organizações de mulheres negras na III Conferência Mundial contra o racismo, xenofobia e intolerâncias correlatas (Geledés, 2014), que aconteceu em Durban, em 2001.

A RFS é uma associação civil sem fins econômicos, criada em agosto de 1991, no contexto do Seminário Nacional Feminista de Saúde e Direitos Reprodutivos, promovido em Itapecerica da Serra (SP), pelo SOS Corpo - Gênero e Cidadania, de Recife (PE), e pelo Coletivo Feminista Sexualidade, de São Paulo (SP). ${ }^{7}$ Em seu sítio institucional, a RFS define-se como "uma articulação política nacional do movimento de mulheres, feminista e antirracismo". 8 A associação de grupos e organizações à RFS é de dois tipos: efetiva (grupos da sociedade civil) ou colaboradora (conselhos estaduais de direitos da mulher). ${ }^{9}$ Ela é composta atualmente por mais de 260 grupos associados, distribuídos em 12 regionais, ${ }^{10}$ as quais englobam capitais das cinco Grandes Regiões do Brasil.

Os órgãos da RFS são a Assembleia Geral, o Colegiado, o Conselho Diretor, a Secretaria Executiva, as Regionais Estaduais e o Conselho Fiscal. Todos os cargos desses órgãos são ocupados por mulheres. A coordenação da RFS é composta pelo colegia-

7 Disponível em: <http://www.redesaude.org.br/hotsite/>. Acesso em: 13 abr. 2015.

8 Disponível em: <http://redesaude.org.br/home/institucional.php >. Acesso em: 16 abr. 2015.

9 A associação efetiva, além de estar aberta apenas para organizações da sociedade civil, implica direito de votar e ser votada durante as assembleias e reuniões da RFS. A associação colaboradora, composta por conselhos estatais de direitos das mulheres, tem em comum direitos e deveres com as associadas efetivas, mas não possui direito a voto ou de ser votada. Ambos os tipos de associação dependem que as organizaçôes concordem com os princípios e políticas da RFS e de forma expressa comprometam-se a não defender posições contrárias àquelas defendidas pela RFS.

10 As regionais são: Pará, Paraíba, Paraná, Pernambuco, Goiás, Bahia, Minas Gerais, Rio de Janeiro, Rio Grande do Sul, São Paulo, Santa Catarina e Distrito Federal. 
do do Conselho Diretor e da Secretaria Executiva. O Conselho Diretor, de caráter eletivo, tem função de acompanhar/aprovar as ações adotadas pela Secretaria Executiva. A Secretaria Executiva, que também é um cargo eletivo, tem como função definir planos de trabalho da RFS, preparar encontros do Colegiado e da Assembleia Geral e representar a RFS judicialmente. Até 2015, a secretária-executiva da RFS era Clair Castilhos, membro da Associação Casa da Mulher Catarina.

A RFS atua por meio de "advocacy e controle social", em diversas instâncias políticas nacionais. São exemplos dessa atuação a presença da RFS na coordenação da Comissão Inter-setorial de Saúde da Mulher do Conselho Nacional de Saúde, no Conselho Nacional dos Direitos da Mulher e na Coordenação da Plataforma Brasileira de Direitos Humanos, Econômicos, Sociais, Culturais e Ambientais - Plataforma DhESCA/Brasil. ${ }^{11}$ Os princípios da ação RFS, conforme definido em seu Estatuto Social, aprovado em maio de 2006, são:

[o] fortalecimento dos movimentos feminista e de mulheres no ambito local, regional, nacional e internacional, em torno da saúde e dos direitos sexuais e direitos reprodutivos; [o] reconhecimento dos direitos sexuais e reprodutivos como direitos humanos; [o] reconhecimento da violência sexual, racial e doméstica como violações dos direitos humanos; [a] defesa da implantação e da implementação de ações integrais de saúde da mulher, no âmbito do Sistema Único de Saúde; [e a] legalização do aborto, cuja realização é decisão que deve competir à mulher como direito (Estatuto Social da RFS; destaques nossos).

${ }^{11}$ Disponível em: <http://redesaude.org.br/home/institucional.php $>$. Acesso em: 16 abr. 2015. 
Assim como os princípios da RFS destacam a sua postura feminista, os objetivos definidos no Estatuto reiteram o compromisso com a promoção dos direitos sexuais e reprodutivos com base na igualdade de gênero. Dos seis objetivos definidos no artigo $3^{\circ}$ do Estatuto Social da RFS, destacamos:

I - Discutir e difundir questões relativas à saúde das mulheres e aos direitos sexuais e direitos reprodutivos, sob uma perspectiva feminista;

II - Influenciar a sociedade brasileira, a sociedade civil e os movimentos sociais para a defesa da equidade de gênero e os direitos humanos das mulheres;

III - Influenciar na formulação, implementação e monitoramento de políticas públicas no País (RFS, 2006; destaques nossos).

Dos princípios e objetivos destacados, a percepção da atuação junto ao Estado está enunciada claramente. $\mathrm{Na}$ definição dos princípios, a RFS ressalta o papel do Sistema Único de Saúde no atendimento às mulheres. Nos objetivos, prevê a necessidade de agir (influenciar e assegurar) junto a todas as fases de elaboração e execução de políticas públicas e aos três poderes republicanos.

A ReHuNa, associação civil sem fins lucrativos, foi criada em 1993, em uma reunião de 34 pessoas - profissionais de saúde, servidores públicos (Prefeitura de Campinas) e ativistas do movimento pela humanização do parto (Redeh - RJ, Casa de Parto Nove Luas, Lua Nova - RJ, Grupo Curumim - PE e Grupo de Parto Alternativo Unicamp - SP) e do movimento feminista (Coletivo Feminista Sexualidade e Saúde - SP) na Chácara Catalina, em Campinas (ReHuNa, 1993). Tal reunião foi organizada por pessoas interessadas na promoção da ideia de parto humanizado, de aproximação do nascer à natureza, da crítica à abordagem técnica e à medicalização no momento do nascimento, com base os princí- 
pios defendidos por Michel Odent ${ }^{12}$ (Tornquist, 2002, 2004). De acordo com o site institucional do ReHuNa, o

objetivo principal é a divulgação de assistência e cuidados perinatais com base em evidências científicas. Essa rede tem um papel fundamental na estruturação de um movimento que hoje é denominado 'humanização do parto/nascimento'. Esse movimento pretende diminuir as intervenções desnecessárias e promover um cuidado ao processo de gravidez/parto/ nascimento/amamentação baseado na compreensão do processo natural e fisiológico ( $\mathrm{ReHuNa}$, s.d.). ${ }^{13}$

$\mathrm{Na}$ Carta de Campinas, a ReHuNa ressalta que o público alvo de suas ações são "homens e mulheres, setores da sociedade civil organizada, profissionais de saúde e educação, planejadores e elaboradores das políticas de saúde" (ReHuNa, 1993). Entre os objetivos específicos da ReHuNa estão o destaque aos riscos de práticas obstétricas intervencionistas, o resgate do nascimento como evento sociocultural, o incentivo à reapropriação da vida pelas mulheres e seu empoderamento no que tange aos corpos e partos.

Assim como a RFS, a ReHuNa é composta por grupos e organizações de origens diferentes. Em 2011, a ReHuNa contava com mais de 290 associados, de acordo com ReHuNa (2011). A ReHuNa está organizada em presidência e vice-presidência, conselho diretor e conselho fiscal. A composição dos órgãos conta com mulheres e homens, e já houve períodos, como no período 2006 a 2009, que o presidente da Rede foi um homem, o médico obstetra Marcos Leite. Atualmente, a presidência da ReHuNa é dirigida pela médica Daphne Rattner.

12 Michel Odent é reconhecido por membros da ReHuNa como um dos autores centrais no ideário do parto humanizado (Tornquist, 2004, p. 151).

13 Disponível em: <http://www.rehuna.org.br/index.php/quem-somos>. Acesso em: 17 abr. 2015. 
Diferentemente da RFS, que trata de diferentes aspectos da saúde das mulheres, a ReHuNa possui um foco específico na temática do parto e do tipo de parto ideal a ser realizado. Assim, as principais campanhas e temas tratados pela ReHuNa são a difusão de informações sobre a atenção à mulher e ao bebê na gestação e no parto (Rattner, 2010, p. 218), a promoção da humanização do parto por meio de palestras e exibição de filmes, a defesa da necessidade de atenção ao óbito fetal e materno, a definição do trabalho das doulas, a formação dessas profissionais e a defesa da atuação das parteiras, a defesa do direito da mulher à presença de acompanhante de sua escolha durante o trabalho de parto e no parto, ${ }^{14} \mathrm{a}$ defesa da construção e legalização de casas de partos e o combate à episiotomia de rotina. ${ }^{15}$

A relação entre a ReHuNa e o feminismo é menos clara que a da RFS. Enquanto esta cita o feminismo e a equidade de gênero no estatuto social, em seus princípios, objetivos e no próprio nome, a aproximação daquela é menos institucional, fazendo-se por meio das falas de algumas rehunidas ${ }^{16}$ na sua abordagem sobre a humanização do parto. Nos documentos oficiais da $\mathrm{ReHuNa}$ a que tivemos acesso, a menção a esses temas aparece mais na "Carta de Fortaleza” (2000). Nessa Carta estão presentes denúncias sobre violência institucional no momento do parto e a defesa da garantia de direitos sexuais e reprodutivos para mulheres e homens, bem como da necessidade de entendimento "[d]as questões de gênero, socioculturais e econômicas que permearam a construção dos diferentes modelos de atenção ao parto e nascimento que conhe-

${ }_{14} \mathrm{O}$ trabalho da ReHuNa junto ao Senado, por meio das articulações criadas com a senadora Ideli Salvati pelo ReHuNa-SC quando era ainda deputada estadual. Em 2005, a lei n. 11.108 foi aprovada, garantindo portanto a presença de acompanhantes em todos os partos no SUS.

15 A episiotomia é o corte feito entre a vagina e o ânus da parturiente. É uma das intervenções médicas consideradas violentas, na medida em que é geralmente desnecessária e gera dificuldades para a recuperação da mulher no pós-parto.

16 As rebunidas são as ativistas da ReHuNa, conforme conceito nativo da organização. 
cemos" (ReHuNa, 2000). No entanto, há passagens na "Carta de Fortaleza"' que reiteram algumas das hierarquias de gênero muito questionadas pelas feministas, como as apresentadas no excerto abaixo, em que as flexões de gênero restringem o trabalho das mulheres às áreas de menor prestígio nos saberes médicos:

A formação dos diversos profissionais, desde a parteira tradicional até o obstetra especialista em gestações de alto risco, passando pela enfermeira obstetra e pelo médico generalista ( $\mathrm{ReHuNa}, 2000$; destaques nossos).

A fala de Simone Diniz, em entrevista, ${ }^{17}$ joga luz sobre a separação entre a ReHuNa e o feminismo:

Havia uma atuação feminista muito forte a respeito da assistência ao parto na década de 80 , tanto no Brasil como em outros países. [...] Isso foi se esvaziando um pouco na década de 90, eu diria até que houve uma separação do ativismo, porque o debate sobre saúde materna deixou de caber no campo da saúde sexual e reprodutiva (Diniz, 2014).

Assim, podemos pensar que a premissa dos membros da ReHuNa quanto ao feminismo é que ele é a base da concepção da proposta de humanização do parto. Nesse sentido, a ReHuNa ressalta o protagonismo das mulheres, derivado de uma condição fisiológica, no momento do parto - são as mulheres aquelas quem deve decidir onde, de que forma e com quem farão o parto - e aponta a intervenção obstétrica como uma forma de controle e violência contra as parturientes (Leite, 2010).

17 Disponível em: http://www.rehuna.org.br/index.php?start=2. Acesso em: 17 abr. 2015. 
A AMNB foi criada em 2000, com o objetivo de organizar e preparar os grupos de mulheres negras para a Conferência de Durban, em 2001. De acordo com o documento Mulheres negras na primeira pessoa, a missão da $\mathrm{AMNB}$ é:

Promover a ação política articulada de organizações não governamentais de mulheres negras brasileiras, realizando enfrentamento ao racismo, ao sexismo, à opressão de classe, à lesbofobia e a todas as formas de discriminação, a fim de contribuir para a transformação das relações de poder existentes no Brasil (Werneck, Iraci e Cruz, 2012, p. 9).

A AMNB é composta por 27 grupos $^{18}$ de mulheres e feministas de 16 unidades federativas. Considerando a luta das mulheres negras, a AMNB traz novos termos para o debate sobre organização de mulheres e busca de políticas públicas: os conceitos de resistência e ancestralidade, e a combinação deles, a resistência ancestral, vinculada às lutas contra a coisificação do corpo das mulheres negras (Werneck, Iraci e Cruz, 2012, p. 11). Além

${ }^{18}$ Os grupos vinculados à AMNB em abril de 2016 são: Centro de Estudos e Defesa do Negro do Pará - Cedenpa (PA); Instituto de Mulheres Negras do Mato Grosso - Imune (MS); Coordenação Nacional das Mulheres - Conaq (MG); Nzinga - Coletivo de Mulheres Negras de Belo Horizonte (MG); Odara - Instituto da Mulher Negra (BA); Grupo de Mulheres Negras Mãe Andressa (BA); Maria Mulher - organização de mulheres negras (RS); Acmun - Associação Cultural de Mulheres Negras (RS); Criola - organização de mulheres negras (RJ); Caces - Centro de Atividades Culturais, Econômicas e Sociais (RJ); Imena - Instituto de Mulheres Negras do Amapá (AP); Associação de Mulheres Mãe Venina do Quilombo do Curiaú (AP); Inegra - Instituto Negra do Ceará (CE); Irohin (DF); Pretas Candangas - Coletivo de mulheres negras do DF (DF); Centro de Referência Negra Lélia Gonzalez (GO); Grupo de Mulheres Negras Malunga (GO); Bamidele (PB); Rede de Mulheres Negras do Paraná (PR); Observatório Negro (PE); Uiala Mukaji - Sociedade das Mulheres Negras de Pernambuco (PE); Kilombo - Organização Negra do RN (RN); Casa da Mulher Catarina (SC); Instituto Amma Psique e Negritude (SP); Àlàáfiá - Programa de Educação, Cultura e Cidadania (SP); Geledés - Instituto da Mulher Negra (SP); e Casa Laudelina de Campos Melo (SP). 
disso, reitera a importância do racismo como obstáculo ao acesso às políticas públicas. Considerando o destaque que a AMNB dá à violência sexista e à superação do sexismo, bem como as publicações na página de Facebook da associação, apesar de não haver uso explícito do termo feminismo em suas publicações podemos afirmar que ela seria considerada uma organização feminista em defesa dos direitos das mulheres negras.

A questão da saúde da mulher negra é um dos temas com que as organizações que compõem a AMNB lidam. Entre as principais demandas e agendas que essas organizações propõem para a saúde da mulher, destaca-se que "o racismo e o sexismo imprimem marcas diferenciadas no exercício desses direitos [sexuais e reprodutivos]" (Lopes e Werneck, s.d., p. 11), a violência institucional decorrente do racismo e que submete as mulheres negras a maiores riscos de morte e de morbidade, "atuação direta na formulação de estratégias e no desenvolvimento de ações de advocacy em políticas públicas, em especial aquelas de interesse das mulheres negras" (Werneck, 2010, p. 2). Outro ponto que é uma das preocupações dos grupos participantes da AMNB é a eugenia e os processos e políticas existentes para fazer desaparecer as marcas de negritude dos corpos ou para matar, desqualificar e exterminar corpos negros.

Do ponto de vista institucional, a AMNB possui eleição para o cargo de secretária-executiva. Dado que é uma associação/ rede mais recente que as outras duas que estamos analisando, a AMNB ainda não está formalizada como entidade ou organização da sociedade civil, não tendo um estatuto com a definição de seu funcionamento. A eleição para o cargo de secretária-executiva tem validade de três anos e com esta função, a organização que a mantém representa a $\mathrm{AMNB}$ nos eventos e reunióes em que ela deve estar presente, como as reuniões do Conselho Nacional de Saúde. Entre 2012 e 2015 a secretaria executiva foi exercida por Jurema Werneck, da ONG Criola, do Rio de Janeiro. 
No Quadro abaixo apresentamos de maneira esquemática algumas referências de criação e militância das redes de ativismo apresentadas nesta seção:

\section{Quadro 1: Resumo de características das três redes de ativismo tratadas no capítulo}

\begin{tabular}{|c|c|c|c|c|}
\hline Rede & $\begin{array}{l}\text { Ano e local } \\
\text { de criação }\end{array}$ & $\begin{array}{l}\text { Setores sociais } \\
\text { envolvidos na criação }\end{array}$ & $\begin{array}{l}\text { Principais demandas } \\
\text { de saúde }\end{array}$ & Outras demandas \\
\hline $\begin{array}{l}\text { Rede Nacional } \\
\text { Feminista de } \\
\text { Direitos Sexuais e } \\
\text { Reprodutivos (RFS) }\end{array}$ & $\begin{array}{l}1991 \\
\text { São Paulo }\end{array}$ & Movimento feminista & $\begin{array}{l}\text { Estabelecimento de } \\
\text { ações } \\
\text { integrais de atenção } \\
\text { à saúde da mulher }\end{array}$ & $\begin{array}{l}\text { Promoção da luta } \\
\text { feminista e antirracista }\end{array}$ \\
\hline $\begin{array}{l}\text { Rede pela } \\
\text { Humanização do } \\
\text { Parto e Nascimento } \\
\text { (ReHuNa) }\end{array}$ & $\begin{array}{l}1993 \\
\text { São Paulo }\end{array}$ & $\begin{array}{l}\text { Profissionais de } \\
\text { saúde, ativistas pela } \\
\text { humanização do } \\
\text { parto, movimento } \\
\text { feminista }\end{array}$ & $\begin{array}{l}\text { Humanização do } \\
\text { parto } \\
\text { e aproximação à } \\
\text { natureza }\end{array}$ & $\begin{array}{l}\text { Fim da medicalização } \\
\text { durante o parto/ } \\
\text { nascimento e da } \\
\text { violência obstétrica }\end{array}$ \\
\hline $\begin{array}{l}\text { Articulação de } \\
\text { Mulheres Negras } \\
\text { Brasileiras (AMNB) }\end{array}$ & $\begin{array}{l}2001 \\
\text { São Paulo }\end{array}$ & $\begin{array}{l}\text { Movimento feminista } \\
\text { negro }\end{array}$ & $\begin{array}{l}\text { Combate ao } \\
\text { racismo e à violência } \\
\text { institucional no } \\
\text { atendimento à saúde }\end{array}$ & $\begin{array}{l}\text { Atenção à eugenia } \\
\text { presente nas políticas } \\
\text { públicas }\end{array}$ \\
\hline
\end{tabular}

Fontes: Documentos das redes de ativismo. Elaboração da autora.

Neste ponto surge uma questão importante a ser problematizada: essas redes trabalham juntas na articulação de demandas de políticas de saúde para as mulheres?

É possível perceber que há distância da abordagem temática da saúde das mulheres entre as redes - uma mais voltada para a questão da saúde integral, a outra para o debate sobre o parto e a maternidade e a terceira voltada para o debate sobre a relação entre a questão racial e o acesso à saúde; duas declaradamente feministas e outra com aproximações pontuais à agenda feminista. Apesar disso, há sobreposição das pessoas e organizações que delas participam - como é o caso de Simone Diniz e do Coletivo Feminista Sexualidade e Saúde, no caso da RFS e da ReHuNa; e da Casa da Mulher Catarina, no caso da AMNB e da RFS. As dinâmicas de múltiplas filiações de ativistas nas redes de saúde pre- 
cisam ser investigadas mais a fundo para que se compreenda de maneira integral de que forma a participação simultânea em diferentes organizações contribui seja para as ativistas, seja para as redes e as suas causas. $\mathrm{O}$ conceito de múltiplas filiações (multiple affiliations) é discutido amplamente por Ann Mische (2008) para as dinâmicas das redes de ativismo juvenil entre o final da década de 1980 e o início da década de 1990. A autora ressalta que esse processo auxilia o fortalecimento tanto de causas como dos movimentos nos quais ativistas com múltiplas vinculações atuam ao mesmo tempo. Isso acontece na medida em que essas pessoas, por um lado, podem provocar tensões sobre a atuação das instituições nas quais estão - podendo, em última instancia, causar paralisia decisória - e, por outro, permitem que inovações e a comunicação entre diferentes setores fluam mais rapidamente, facilitando a mobilização em torno de determinados pontos da causa nas quais militam.

Para além da questão da sobreposição, há ações em que as redes atuam como parceiras, como é o caso da publicação do dossiê "Humanização do parto", de 2002. O dossiê foi escrito e organizado por ativistas da RFS e da $\mathrm{ReHuNa},{ }^{19}$ mas foi patrocinado e publicado apenas pela RFS. Nele, a definição da humanização do parto relaciona luta feminista e maternidade:

Mais do que promover a utilização ou não de determinadas práticas, o resgate do papel central e ativo da mulher no processo da gravidez e do nascimento é o foco da luta feminista pela humanização da assistência. A maternidade segura é um princípio básico dos direitos reprodutivos, assim como o direito da mulher de tomar suas decisões de maneira bem informada em relação a seu corpo, sua saúde, sexualidade e reprodução (RFS, 2002, p. 12).

19 Simone Grilo Diniz (RFS e ReHuNa), Alessandra Chacham (RFS) e Daphne Rattner (ReHuNa). 
Apesar de concordarem no tema da humanização, as reações das redes, especificamente ao Rede Cegonha, são antagônicas. Essa dinâmica demonstra que seria necessário um aprofundamento da análise quanto à composição das redes, as tensões internas sobre as agendas dos grupos que delas participam e as razões da adesão dos grupos a ambas as redes, bem como o funcionamento das redes na intermediação e resolução de conflitos internos, assunto para um novo capítulo sobre a organização do movimento de mulheres sobre saúde.

\section{Paradigmas das políticas de saúde, ativismo e encaixes socio- estatais.}

A gente que faz politica tem de denunciar. Cada vez que eles cometerem equívocos gigantes, como o decreto da Rede Cegonha e a MP 557, só temos uma alternativa: lutar (Werneck, 2012, s.p.).

As políticas de saúde para as mulheres no quartel final do século XX podem ser classificadas em dois paradigmas. Primeiramente, de 1975 até 1983, temos o paradigma da saúde materno-infantil, cuja ênfase volta-se aos cuidados da mulher gestante e em que "não existe a mulher, só existe 'barrigão"” (Vilela, 2002, p. 87). Segue-se a esse paradigma, entre 1983 e 2007, o paradigma da saúde da mulher, em que a ênfase da política de saúde é a integralidade das ações da política, voltada para as principais causas de morbimortalidade, contemplando a abordagem de planejamento familiar, câncer e DSTs/Aids. Dada a possibilidade de propostas interseccionais de políticas de saúde e a consideração das determinações socioeconômicas para a existência de saúde e doença, o paradigma de atenção integral à saúde das mulheres representa o paradigma de saúde ao qual nos subscrevemos normativamente. 
Acreditamos que o paradigma materno-infantil representa foco específico na política de saúde que exclui de suas preocupações mulheres e eventos da vida sexual e reprodutiva das mulheres que não podem ser relegadas a um papel inferior nas políticas de saúde coletiva. Abaixo, traçamos um breve histórico das políticas desenhadas para as mulheres, de forma a demonstrar a mudança entre esses paradigmas durante o século XX.

Exemplar do primeiro paradigma é o Programa MaternoInfantil (PMI), lançado em 1975, que consagrava a abordagem tradicional e gineco-obstétrica de tratamento da saúde da mulher, como podemos observar na justificativa do programa: "Tomando como base o processo biológico de formação, crescimento e desenvolvimento do ser humano, são consideradas prioritárias, na política de saúde materno-infantil, a mulher no decurso da gestação, parto e puerpério e a criança menor de 5 anos, para as ações integradas de saúde" (Brasil, 1975, p. 60; destaques nossos). À época, o objetivo explícito do programa era reduzir a morbimortalidade do grupo materno-infantil. O programa era composto por 12 subáreas, das quais nove (75\%) estavam voltadas para atenção à gravidez, ao parto ou à criança, evidenciando as razões pelas quais o programa foi criticado por se restringir a uma fase muito específica da vida de algumas mulheres. A única subárea voltada para o atendimento de saúde para além da gravidez e do parto é a de "Doenças ginecológicas, incluindo as venéreas e o câncer", que apresenta a descrição mais breve: "Diagnóstico precoce e tratamento" (p. 61). A responsável pela implementação do PMI era a doutora Dalva Coutinho Sayeg, que recebeu o apoio da Legião Brasileira de Assistência (LBA), da Fundação Cesp; da Escola Nacional de Saúde Pública (ENSP), da Organização Pan-Americana de Saúde e da Fundação Kellog para a implementação da política (Brasil, 2011b, p. 19). Não há registro da presença de feministas entre a equipe da doutora Sayeg e, em mensagem deixada em entrevista realizada pelo Ministério da Saúde em 2009, a médica ressalta a importância do 
cuidado com as crianças para o desenvolvimento do país, ${ }^{20}$ não havendo menção seja ao papel das mulheres, seja a uma abordagem integral da saúde.

Durante os anos 1980, as práticas de organizações como a Sociedade Civil Bem-Estar Familiar no Brasil (Bemfam) e o International Planned Parenthood Federation (IPPF) serão amplamente criticadas pelas feministas no mundo e no Brasil. ${ }^{21} \mathrm{Em}$ razão dessas denúncias, em 1983, foi instalada uma Comissão Parlamentar de Inquérito, em que o Executivo foi instado a explicar a presença e atuação de grupos estrangeiros e prever ações para suspender as práticas irregulares. É durante uma das sessões da CPI que o Ministro da Saúde lança o Programa de Assistência Integral à Saúde da Mulher (PAISM), como forma de resposta à pressão da sociedade civil e dos parlamentares.

O PAISM inaugura o segundo paradigma de abordagem das políticas de saúde ao tratar da saúde da mulher e não mais da saúde materno-infantil. Ele está dividido em três subáreas, das quais duas estão voltadas para os cuidados da mãe do concepto, e a primeira, a de assistência clínico-ginecológica, tem entre suas prioridades a “orientação sobre planejamento familiar" (Brasil, 1985, p. 19, destaques nossos). A previsão do planejamento familiar como questão de saúde é uma das principais novidades do PAISM, inaugurando uma tendência que só no final dos anos 1980 seria consagrada internacionalmente como "direitos reprodutivos". Apesar dos avanços previstos pelo PAISM, a implementação da política encontrou dificuldades, sobretudo quanto ao acesso ao tratamento integral e à orientação do planejamento familiar (Osis, 1998; Costa, 2009).

20 "Cuidar da criança é dever de todos para que se possa ter uma população com cidadãos que vai dar continuidade ao desenvolvimento do país” (Sayeg apud Brasil, 2011b, p. 19).

21 Sobretudo em razão da compulsoriedade das laqueaduras realizadas, da desinformação das mulheres atendidas e da distribuição indiscriminada de contraceptivos orais. 
Entre as responsáveis pelo desenho do PAISM destaca-se o trabalho da médica sanitarista Ana Maria Costa e da socióloga Maria da Graça Ohana. Apesar de no período em que desenharam o PAISM não integrarem grupos feministas, ${ }^{22}$ ambas se identificam como feministas, tendo como objetivo promover a alteração das políticas de saúde para atender a todos os momentos do ciclo de vida das mulheres, não apenas durante a gravidez e o puerpério. O processo de elaboração do PAISM deve ser ressaltado também como um processo de criação de um instrumento de política. Isso se dá à medida que a ideia de integralidade das políticas de saúde e da observação das mulheres como seres complexos, com diferentes demandas para além da maternidade, passa a ser um elemento básico de qualquer política que venha a abordar os corpos das mulheres. Como veremos a seguir, a falta de uma abordagem integral às questões de saúde das mulheres é uma das críticas endereçadas às políticas mais recentes voltadas para a saúde das mulheres.

Durante os anos 2000, foco deste capítulo, temos ambos os paradigmas vigorando nas políticas de saúde para as mulheres. Em 2004, foi lançada a Política Nacional de Atenção Integral à Saúde da Mulher (PNAISM), cuja vigência prevista era de 2004 a 2007. Ela retoma princípios do PAISM e pode ser localizada dentro do paradigma de saúde da mulher. De acordo com o documento de princípios e diretrizes da política, ela foi formulada com a participação ampla da sociedade civil - movimentos de mulheres e a SPM (Brasil, 2004b, p.5) - e destaca a preocupação das políticas de saúde como políticas de defesa e promoção dos direitos humanos, particularmente dos direitos sexuais e reprodutivos. Na apresentação da PNAISM destaca-se a amplitude das questões que a política pretende trabalhar, como é possível perceber no excerto abaixo:

22 Ana Maria Costa é uma das fundadoras da RFS e foi secretária-executiva da RFS. 
Este documento incorpora, num enfoque de gênero, a integralidade e a promoção da saúde como princípios norteadores e busca consolidar os avanços no campo dos direitos sexuais e reprodutivos, com ênfase na melhoria da atenção obstétrica, no planejamento familiar, na atenção ao abortamento inseguro e no combate à violência doméstica e sexual. Agrega, também, a prevenção e o tratamento de mulheres vivendo com HIV/Aids e as portadoras de doenças crônicas não transmissiveis e de câncer ginecológico. Além disso, amplia as ações para grupos historicamente alijados das políticas públicas, nas suas especificidades e necessidades (Brasil, 2004b, p. 5; destaques nossos).

A justificativa da política traz as implicações do gênero na saúde, particularmente dos efeitos das hierarquias de gênero na saúde das mulheres combinadas a outras hierarquias - como as de raça e etnia, orientação sexual, idade e classe social. Nesse sentido, ressaltam-se a necessidade de atenção específica às mulheres negras, indígenas, lésbicas e trabalhadoras rurais, às mulheres na adolescência e no climatério, às idosas; e a defesa de aumento da participação social na implementação das políticas de saúde.

No diagnóstico que antecede a apresentação dos objetivos da PNAISM, ressalta-se a importância da atuação dos movimentos de mulheres e feminista para a adoção de políticas de saúde das mulheres, dessas como sujeitos de seus corpos, donas de corpos diversos entre si. O diagnóstico perpassa os diversos temas de saúde coletiva, entre eles as causas de mortalidade. As causas de mortalidade mais comuns entre as mulheres são as doenças do aparelho circulatório, as neoplasias e as causas externas. Apesar de ainda haver muitas mortes decorrentes da gravidez e do parto entre as mulheres em idade fértil (15 a 49 anos),

[a] mortalidade associada ao ciclo gravídico-puerperal e ao aborto não aparece entre as dez primeiras causas de óbito nessa 
faixa etária. No entanto, a gravidade do problema é evidenciada quando se chama atenção para o fato de que a gravidez é um evento relacionado à vivência da sexualidade, portanto não é doença, e que, em 92\% dos casos, as mortes maternas são evitáveis (Brasil, 2004b, p. 26).

Com base no diagnóstico realizado, são enunciados três objetivos gerais e 14 objetivos específicos. Os objetivos específicos tratam, entre outras questões: da atenção clínico-ginecológica; da assistência em planejamento familiar para mulheres e homens; da atenção obstétrica e neonatal e da assistência ao abortamento; da atenção às vítimas de violência doméstica e sexual; do controle e prevenção de DST e HIV/Aids; da redução da morbimortalidade por câncer; da atenção à saúde mental; da criação de iniciativas específicas para as mulheres adolescentes, idosas, negras, indígenas, trabalhadoras rurais, lésbicas e em situação de prisão.

Como a PNAISM traz em seu texto apenas os princípios, diagnóstico e diretrizes a serem adotadas, foram criadas iniciativas de implementação dos objetivos da política para os três níveis de governo por meio de pactos específicos às diferentes áreas ressaltadas pela política. Considerando nosso objetivo de comparar as duas políticas e sua recepção pelas redes de saúde das mulheres, destacamos o Pacto Nacional pela Redução da Mortalidade Materna (Pacto), que traz ações e medidas práticas a serem implementadas no que tange à atenção das mulheres grávidas.

O Pacto está previsto entre as diretrizes da PNAISM e também foi lançado em 2004, reiterando elementos já existentes na Política, como é o caso da necessidade de humanização e qualidade no atendimento e as especificidades do tratamento da saúde das mulheres negras e indígenas. Emblemática da forma como o Pacto aborda a saúde da mulher no documento é a frase: "O Governo Brasileiro tem como uma de suas prioridades na área da saúde 
as políticas públicas para atenção integral à saúde da mulber e da criança" (Brasil, 2004a, p. 3, destaques nossos).

Durante o governo Dilma Roussef, a principal política de atenção à saúde das mulheres foi a Rede Cegonha. Ela foi instituída em 2011 por meio do decreto n. 1.459 do Ministério da Saúde e é caracterizada como:

uma rede de cuidados que visa assegurar à mulher o direito ao planejamento reprodutivo e à atenção humanizada à gravidez, ao parto e ao puerpério, bem como à criança o direito ao nascimento seguro e ao crescimento e ao desenvolvimento saudáveis (Brasil, 2011a).

As justificativas para a política são iniciativas anteriores de saúde das mulheres, as altas taxas de mortalidade materna no Brasil e a urgência em cumprir compromissos internacionais, particularmente as metas dos Objetivos do Milênio.

A Rede Cegonha possui três objetivos: "fomentar a implementação de um novo modelo de atenção à saúde da mulher e da criança"; "organizar a Rede de Atenção à Saúde Materna e Infantil"; e "reduzir a mortalidade materna e infantil" (Brasil, 2011a; destaques nossos). Apesar da expressão "saúde da mulher e da criança" no texto da política, destacamos o uso do termo "saúde materna”, que é reiteradamente utilizado nessa portaria e outros documentos de implementação da Rede Cegonha. Assim como o PMI, da década de 1970, a Rede Cegonha é exemplo do paradigma de saúde materno-infantil e repete a especialização do cuidado em uma fase da vida de algumas mulheres.

Tendo em vista a descentralização implicada nas políticas de saúde, a Rede Cegonha possui cinco fases operacionais: (i) adesão e diagnóstico - com apresentação do programa a estados e municípios, bem como a montagem de um cronograma de implementação; (ii) desenho regional da Rede Cegonha - desenho 
de mapas e fluxos da atenção à saúde materna e infantil na Região de Saúde, momento em que há a previsão de participação da sociedade civil; (iii) contratualização dos pontos de atenção - desenho da Rede Cegonha no âmbito municipal, com a elaboração de Plano de Ação Municipal e constituição do Fórum Municipal da Rede Cegonha; (iv) qualificação dos componentes - verificação da atuação de cada um dos componentes da rede por meio do acompanhamento das metas definidas nos planos de ação estaduais e municipais; e (v) certificação dos municípios e da rede de cuidado.

Os parâmetros de qualidade do atendimento da Rede Cegonha baseiam-se nas normas técnicas da OMS, publicadas em 1985. Tais normas estão divididas em quatro categorias de acordo com sua utilidade para o momento do parto, com base em “evidências científicas". Dessa forma, há desde "práticas demonstradamente úteis e que devem ser estimuladas" 23 a "práticas frequentemente utilizadas de modo inadequado" (Brasil, s.d., p. 24). Nesta última categoria encontram-se o parto operatório; o uso de peridurais, de máscaras e aventais e os exames vaginais repetidos no momento do parto.

Os centros de parto normal (CPN) e as casas de gestante, bebê e puérpera (CGB), são parte importante do programa. Os primeiros são responsáveis pelo atendimento das mulheres com gravidez considerada de baixo risco ou normal, em que se dispensa a atuação de médicas obstetras e ressaltam-se os valores vinculados à humanização do parto, como a presença de acompanhantes e a liberdade da escolha da posição para parir. Os CPNs foram criados em 1999 e desde então têm sido fortemente defendidos por grupos

23 São exemplos de práticas a serem estimuladas: a privacidade da mulher no momento do parto, Respeito à escolha da mãe sobre o local do parto, Liberdade de posição e movimento durante o trabalho de parto, Contato cutâneo direto precoce entre mãe e filho e apoio ao início da amamentação na primeira hora após o parto, segundo as diretrizes da OMS sobre Aleitamento Materno (Brasil, s.d., p. 25). 
de mulheres que defendem a humanização do parto e igualmente combatidos por associaçóes médicas que tentam desqualificá-los como locais seguros de atendimento às gestantes pela ausência de médicos e de recursos técnicos para evoluções problemáticas dos partos. As CGBs são voltadas ao atendimento de mulheres com gravidez de alto risco para a mulher ou para a criança, que demandam atenção diária e cuidados médicos ostensivos. A separação entre as CPNs e as CGBs ao criar a noção de diferentes níveis de atenção às gestantes, a depender das condições fisiológicas das parturientes, e de relativizar a necessidade da atenção médica é também um exemplo da criação de instrumento de políticas públicas. As parturientes deixam de ser consideradas como uma categoria única a quem deve ser endereçada uma solução padronizada pelo Estado, de intervenção médica, e passam a ser entendidas dentro da complexidade de situações de saúde. Com isso, a política de parto e nascimento é alterada, permitindo a redução da intervenção médica e técnica no corpo das mulheres e ressaltando a importância da autonomia decisória no momento do parto.

A elaboração do manual de implementação da Rede Cegonha contou com a parceria da $\mathrm{ReHuNa}$ (Brasil, s.d., p. 4). Entre as novidades apresentadas pelo manual, há a previsão de reformas dos espaços de preparação para o pré-parto, o parto e o pós-parto e de distribuição de kits de atendimento para as parteiras. O destaque para a necessidade de privacidade em todos os momentos próximos ao parto, apesar de não ser uma das bandeiras explícitas de mobilização da ReHuNa, é parte da abordagem de humanização do parto. Podemos afirmar que há nessa necessidade uma abordagem específica de classe que privilegia o privado ou o coletivo encerrado no grupo familiar em detrimento dos espaços coletivos públicos existentes nas salas partilhadas de preparação para o parto, comuns no atendimento gineco-obstétrico não apenas no SUS, mas em diferentes sistemas de saúde. Em geral, as salas compartilhadas de pré e pós-parto são entendidas como 
espaços para formação de laços de apoio e solidariedade e de troca de informação entre as mulheres que serão mães. As salas privadas, que ressaltam a individualidade das mulheres e ressaltam o papel desempenhado pela família como suporte da gravidez, falham em perceber que muitas mulheres estão sozinhas no momento do parto, o que reitera a particularidade das mulheres abordadas pelo programa Rede Cegonha.

Outra iniciativa para a saúde da mulher durante o ano de 2011 foi a elaboração da MP 557, que criava Sistema Nacional de Cadastro, Vigilância e Acompanhamento da Gestante e Puérpera para Prevenção da Mortalidade Materna. Esse sistema visava a cadastrar gestantes, puérperas e nascituros com o objetivo de "garantir a melhoria do acesso, da cobertura e da qualidade da atenção à saúde materna, notadamente nas gestações de risco" (Brasil, 2011a). A MP 557/2011, entre outras coisas, previa o fornecimento de auxílio financeiro para as mulheres garantirem sua ida à maternidade no dia do parto e exigia que prestadores de saúde públicos e privados incluíssem "relação de gestantes e puérperas de risco atendidas nos serviços de saúde, seu diagnóstico e o projeto terapêutico definido e executado" no Sistema (idem, ibdem) e relatassem no mesmo Sistema "a ocorrência de óbitos de mulheres gestantes ou puérperas, com informações sobre a investigação das causas do óbito e das medidas a serem tomadas para evitar novas ocorrências" (idem, ibdem). A MP 557/2011 é parte das mudanças da abordagem de saúde da mulher dentro do paradigma de saúde materno-infantil. 
Quadro 2: Resumo de características das políticas de saúde para as mulheres dos anos 2000

\begin{tabular}{|c|c|c|}
\hline & PNAISM & Rede Cegonha \\
\hline Criação e vigência & Sim & A partir de 2011 \\
\hline $\begin{array}{c}\text { Participação da sociedade civilno } \\
\text { desenho da política }\end{array}$ & Não \\
\hline Ênfase da política & Sim & Mortegralidade materna \\
\hline Interseccionalidade de atenção à saúde & Nã̃o \\
\hline Orientação sexual & Presente & Ausente \\
\hline Identidade de gênero & Ausente & Ausente \\
\hline Ambiência & Ausente & Presente \\
\hline Paradigma de saúde & Saúde da Mulher & Materno-Infantil \\
\hline
\end{tabular}

Fonte: Documentos das políticas. Elaboração da autora.

As duas políticas de saúde da mulher dos anos 2000 foram recebidas pelo movimento de mulheres de forma diferenciada. Nossa atenção estará particularmente voltada ao Rede Cegonha, na medida em que as reações a esse programa foram antagônicas.

\section{Quadro 3: Avaliação das redes em relação as políticas de saúde para as mulheres nos anos 2000}

\begin{tabular}{|c|c|c|}
\hline & PNAISM & Rede Cegonha \\
\hline RFS & Positiva & Negativa \\
\hline ReHuNa & Positiva & Positiva \\
\hline AMNB & Positiva & Negativa \\
\hline
\end{tabular}

Fonte: Entrevistas com ativistas das redes. Elaboração da autora. 
A PNAISM é, em larga medida, entendida como uma atualização do PAISM: "a efetiva implementação do PAISM, hoje PNAISM (Política Nacional de Atenção Integral à Saúde da Mulher) permanece como um desafio para as políticas públicas e para o movimento de mulheres" (RFS, 2008, p. 2). Para as ativistas da RFS e da ReHuNa, o PAISM inaugura a presença das feministas no Ministério da Saúde. A PNAISM, ao atualizá-lo, manteria então a presença histórica dessas feministas na política de saúde das mulheres. Daphne Rattner, da ReHuNa, destaca que a PNAISM:

preenche antigas lacunas ao introduzir as ações de atenção ao climatério, as queixas ginecológicas, a reprodução humana assistida, atenção ao abortamento inseguro e a segmentos da população feminina historicamente alijados das políticas públicas, nas suas especificidades e necessidades (Rattner, 2014, p. 104).

Para as organizações de mulheres negras, na voz de Fátima Oliveira (2011), a PNAISM representa um momento em que "as forças políticas da atenção integral à saúde da mulher tiveram voz e vez", reiterando o caráter participativo da elaboração da PNAISM e a articulação dos grupos e movimentos de mulheres.

Em contraponto ao relativo consenso quanto à PNAISM, há bastante disputa em torno da Rede Cegonha. Para as ativistas da RFS, como a Rede Cegonha parece substituir a PNAISM, a troca das políticas de saúde das mulheres representou um "retrocesso de 30 anos" (Negrão, 2011), uma perda dos temas abordados da integralidade da saúde das mulheres, já que o foco da política é a saúde no momento de gravidez, parto e puerpério. Entre as críticas sobre o reducionismo da política, representantes da RFS ressaltam que mesmo no que tange aos direitos reprodutivos, a Rede Cegonha não trata do aborto, ressaltando o conceito de mulher-mala (Oliveira, 2011) e de desumanização da mulher grávida: 
A política anunciada é só para as mulheres que querem filho ou aquelas que, mesmo que sem nenhuma condição, vão ter filho contra a própria vontade. Logo, não é uma política que considerou que há mulheres que engravidam e não desejam levar adiante aquela gestação ou que engravidaram em circunstâncias adversas à sua vontade (Negrão, 2011).

Além da especificidade do tratamento da saúde da mulher, a Rede Cegonha é apontada como uma política de cuja elaboração a sociedade civil foi alijada, perdendo-se o debate teórico-político que fomentou a criação da PNAISM (Oliveira, 2011). Clair de Castilhos (2011), da RFS, demanda que a presidenta ouça as mulheres em contraponto aos marqueteiros, a quem ela atribui a concepção da política no momento de reação ao debate sobre o direito ao aborto durante a campanha eleitoral de 2010. Nesse sentido, Télia Negrão, da RFS, ressalta que:

Em 22 de março - o lançamento foi no dia 28! -, a Rede Cegonha nos foi apresentada numa oficina de trabalho no Ministério da Saúde. Além das agências governamentais e agências de saúde das Nações Unidas, estiveram presentes uma integrante do Conselho Nacional de Saúde, uma do Conselho Nacional dos Direitos da Mulher, representado pela Abrasco [Associação Brasileira de Saúde Coletiva], a Rede Feminista de Saúde e pessoas da Pastoral da Criança da CNBB [Conferência Nacional dos Bispos do Brasil] (Negrão, 2011).

Jurema Werneck, secretária-executiva da AMNB, ressalta que a adoção do Rede Cegonha e da MP 557/2011 "não resol$\mathrm{ve}[\mathrm{m}]$ a questão da morte materna, atropela $[\mathrm{m}]$ arrogante e explicitamente os sujeitos sociais e princípios fundamentais" (Werneck, 
2012), reiterando a importância de que o governo fale com as mulheres e com os movimentos sociais para entender o que precisa ser tratado no momento em que se fazem políticas de atenção à saúde. Sobre os erros de concepção do Rede Cegonha e a necessidade de participação da sociedade civil, Werneck ressalta:

Então, a gente poderia ter agregado muito. Se os assessores da presidenta Dilma ainda não entenderam o que os próprios números do sistema de informação do SUS revelam, a gente poderia ter explicado melhor. Assim como a gente poderia ter explicado a questão da negligência, do despreparo dos profissionais, da incapacidade do SUS atender da forma como a lei manda, cumprindo assim os direitos das pessoas. Afinal, a gente vive isso todo dia e a nossa luta nesses anos todos tem sido para explicar isso melhor (Werneck, 2012, s.p.).

Quanto à participação da CNBB, Negrão ressalta o seu estranhamento em relação à presença da instituição. Em entrevista, Fátima Oliveira (2011) afirma que "O Ministério da Saúde ao retomar o conceito de saúde materno-infantil adoça a boca do Vaticano!” Simone Diniz (2014), da ReHuNa, também acredita que o nome da política "pretende sinalizar a lealdade com a Igreja e o rompimento com movimento feminista”. Para Jurema Werneck, o principal problema da participação da CNBB é a falta de representatividade dos interesses das mulheres no seio da Igreja católica:

Desde quando a CNBB é a melhor interlocução para dizer o que as mulheres querem e necessitam? É um organismo de uma hierarquia, onde só homem opina, onde só homem manda. Homem que, a rigor não passa pela experiência de uma gestação, de um parto, de um nascimento, de um atendimento de violência 
sexista, racista que o SUS pode oferecer, que está por trás da alta taxa de mortalidade materna no Brasil (Werneck, 2012, s.p.)

Além dessa concordância quanto ao papel da Igreja católica na formulação da Rede Cegonha, as ativistas da RFS e da ReHuNa concordam quanto à necessidade da atenção às mulheres no momento da gravidez e a necessidade da redução da morbimortalidade materna, discutidas pela Rede Cegonha. No entanto, para as ativistas da RFS mesmo esse debate representa uma perda na medida em que os temas levantados pela Rede Cegonha estão contemplados no Pacto de 2004 e que a Rede Cegonha apresenta um caráter limitador ao pensar no papel da mulher apenas como mãe.

Para além desses pontos de convergência, a reação das ativistas da ReHuNa ao Rede Cegonha é diferente da das ativistas da RFS. As falas de Simone Diniz e Daphne Rattner demonstram esta diferença:

A Rede Cegonha [...] traz um questionamento interessante ao modelo médico-centrado, por meio da proposta de criação de casas de parto, da incorporação da enfermeira obstetriz e da obstetriz. Enfim, são propostas potencialmente positivas (Diniz, 2014; destaques nossos).

A Rede Cegonha representa o avanço no sentido de proteção integral ao processo de gestação-parto-nascimento-puerpério e início da vida tanto em termos da gestão do cuidado, como da gestão do sistema, fazendo parte de uma politica nacional ampliada de atenção integral à saúde das mulheres e das crianças. Como uma das principais inovações, saliente-se a diversificação de pontos de atenção, como Centros de Parto Normal; Casa de gestante de alto risco; alojamento para mães de bebês que ficaram internados; e outros (Rattner, 2014, pp. 106-107, destaques nossos). 
No sítio institucional da ReHuNa, a Rede Cegonha é entendida como uma estratégia de mudança do modelo de atenção ao parto e nascimento. A ReHuNa organizou um seminário em 2012, com a finalidade de fortalecer as ações da Rede Cegonha por meio do debate e incentivo da atuação dos CPNs.

A MP 557/2011 é tratada pela RFS e pela AMNB também como um "equívoco", mas com um nível superior de preocupação na medida em que ela é entendida como uma forma de controlar as mulheres e penalizar aquelas que realizarem abortos, por um lado. Por outro, a MP desenhada durante o primeiro ano do governo, assim como a Rede Cegonha, não trata da principal causa de mortalidade das mulheres que é a falta de acesso a cuidado de qualidade, que só poderia ser fornecido por profissionais mais investidos na garantia da saúde integral e do respeito às usuárias do SUS.

A política de saúde tem como um de seus princípios a participação da sociedade civil. Essa participação está garantida institucionalmente, por exemplo, nas Conferências Nacionais de Saúde, mas também no Conselho Nacional de Saúde, tripartite, composto por membros do governo, da sociedade civil e de representantes profissionais. A atuação das feministas para tentar reparar aquilo que entenderam como derrotas representadas pelo decreto que institui a Rede Cegonha e pela MP 557/2011 deu-se diretamente nas reunióes do CNS, em que a AMNB e a RFS possuíam assento e eram representadas por Jurema Werneck e por Santinha, respectivamente, no ano de 2012. Com base na atuação junto ao CNS e por meio também de conversas com a área técnica de saúde da mulher, algumas mudanças são alcançadas no sentido de reduzir os impactos negativos das políticas desenhadas durante o primeiro ano do governo Dilma. A declaração de Jurema Werneck indica a importância da atuação dos movimentos sociais e do CNS na correção das políticas adotadas: "No Conselho Nacional de Saúde e nos movimentos sociais, a gente está tentando, primeiro, pôr 
um freio de arrumação nesse negócio" (Werneck, 2012; destaque nosso).

A pressão por parte do movimento feminista e do movimento de mulheres faz que inicialmente a figura do nascituro seja retirada do texto da MP, que passa a demandar o cadastro somente para gestantes e puérperas (Diniz, 2012, p. 129). A pressão contínua faz que o governo não pressione para a sua votação pelo Congresso Federal e que as medidas por ela descritas não sejam implementadas nas unidades de saúde. A MP perde validade por caducidade e é comemorada como uma vitória do movimento de mulheres com ressalvas, já que o governo optou por esperar que caducasse, mas não a retirou do ordenamento jurídico pelos 120 dias em que podia ter efeitos.

A nomeação da ministra Eleonora Menicucci para a Secretaria de Políticas para as Mulheres no início de 2012 é também percebida como uma sinalização do governo para tentar aplacar as críticas quanto à condução da política de saúde para as mulheres. A SPM e a Seppir são entendidas como "espaços de resistência" dentro do governo:

Cabe ao 'batalhão da mata', às 'prendas do Rosário' - às ministras da Mulher, Eleonora Menicucci, e da Igualdade Racial, Luiza Bairros - sangrar nos cacos: exigindo uma concertação, não para monitorar políticas de saúde, mas para defini-las em pé de igualdade com o MS (Oliveira, 2011).

Em relação ao Rede Cegonha, as mudanças são mais limitadas à forma de sua condução pela área técnica de saúde da mulher e das normativas e orientações enviadas às unidades de saúde de modo a fazer o programa mais adequado às necessidades das mulheres e à percepção das redes de ativismo em relação aos imperativos de atenção à saúde das mulheres gestantes. $\mathrm{O}$ fato de o nome do programa não ter sido alterado, entretanto, permanece 
como um desafio e uma sinalização dos limites das interações entre os movimentos feministas e o Estado, representado pelo MS. É importante lembrar, entretanto, que parte do movimento de mulheres, como a ReHuNa, é favorável e apoia o formato que a Rede Cegonha assumiu, acrescentando tensão dentro dos movimentos de mulheres e, em certa medida, legitimando a adoção do curso tomado pelo MS.

Ao mesmo tempo, a participação por meio da presença nas reuniões do CNS, em que as ativistas modificam as políticas apresentadas pelo governo, provoca alterações na forma como a política é abordada por elas. Depois do "freio de arrumação" e da resistência dentro dos canais institucionais do MS, as mulheres passam a reconhecer a política como o melhor resultado possível, apesar das circunstâncias negativas para a agenda de saúde das mulheres em geral. Assim, muda-se não apenas a política, mas modulam-se as críticas das ativistas em relação às políticas adotadas.

\section{Conclusão}

Considerando que os encaixes socioestatais são entendidos como a sedimentação institucional da relação entre o Estado e os atores sociais, neste capítulo foi possível perceber a atuação de um tipo específico de encaixe em funcionamento em relação às políticas de saúde para as mulheres. Mais do que um exercício de altimetria da atuação do movimento de mulheres e feministas quanto aos processos de desenho e implementação das políticas recentes, nossa análise buscou cobrir a agência desses movimentos em relação às políticas postas em prática durante os anos 2000, bem como suas reações na modificação dessas políticas e das demandas dos movimentos ao Estado brasileiro em temas de saúde das mulheres. Desta maneira pudemos ressaltar as interações entre as ativistas e o Estado, os efeitos dessas interações nas políticas, a heterogeneidade das redes de ativismo e sua capacidade de agência. 
A observação das reações das três redes de ativismo de saúde permitiu perceber as variações de abertura da burocracia estatal a umas e às outras redes com resultados claros no resultado das políticas elaboradas durante os anos recentes do trabalho do Ministério da Saúde para essa área específica da saúde coletiva. Ao mesmo tempo, foi-nos possível perceber que as redes de ativismo mantêm-se ativas em busca de consolidar avanços nas políticas de forma que elas representem um alinhamento entre bandeiras e demandas tradicionais do movimento de mulheres e feminista. Nesse sentido, ressalte-se o caráter participativo das políticas de saúde no modelo adotado pela Constituição de 1988.

Nas políticas que analisamos, entretanto, tal participação dá-se de maneira diferente para a PNAISM e para a Rede Cegonha. Na PNAISM a participação está na base de elaboração do texto da política, estando as três redes presentes no processo de negociação e assinatura do texto da política. Essa participação faz que RFS, ReHuNa e AMNB reconheçam a legitimidade e correção da política nos marcos de sua atuação em defesa seja da saúde das mulheres, seja da humanização de atendimento, seja no reconhecimento e combate à violência institucional contra mulheres negras. Diferentemente, na Rede Cegonha, a participação é posterior à edição do decreto da política de saúde - que não tem sua autoria identificada - e refere-se unicamente a normatizar a forma de implementação da política localmente, usando dos conhecimentos sobre humanização do parto e nascimento construídos por uma das redes, a ReHuNa. As críticas à Rede Cegonha em parte referem-se à exclusão das redes de ativismo da concepção inicial da política, do interesse vinculado apenas a dar uma resposta ao processo eleitoral de 2010, sem contar com as demandas dos movimentos de mulheres e feministas para a edição do decreto. $\mathrm{Na}$ busca por apaziguar os questionamentos referentes à edição do decreto da Rede Cegonha, o governo Dilma Roussef nomeia uma feminista para a SPM e deixa de pressionar pela aprovação da MP $557 / 2011$, o que ressalta a importância da interação entre redes de 
ativismo e o governo federal para o desenho das políticas públicas - seja na sua concepção integral, seja no processo de definição mais específico das ações da política.

Assim, a abordagem de encaixes socioestatais permite que se superem as perguntas mais rígidas feitas tanto pelas teorias mais restritas sobre a relação entre o feminismo e o Estado como avançar nos resultados da cooperação entre ativistas e o Estado mesmo quando não há instituições formais que lidem com as políticas de promoção de equidade de gênero, previstas pelo modelo de feminismo de Estado. Dessa forma, os encaixes socioestatais permitem que se percebam os diferentes fatores intervenientes no processo de agência dos movimentos sociais em relação ao Estado e às políticas públicas, bem como os resultados alcançados nessas interações.

\section{ReferênCIAS}

ABERS, Rebecca; TATAGIBA, Luciana. Institutional Activism: Mobilizing for Women's Health from Inside the Brazilian Bureaucracy. In: Encontro Anual da Anpocs, 38., 2014, Caxambu. Anais... Caxambu: Anpocs, 2014.

ABERS, Rebecca; TATAGIBA, Luciana. Institutional Activism: Mobilizing for Women's Health from Inside the Brazilian Bureaucracy. In: Rossi, Federico M.; von Bülow, Marisa. Social Movement Dynamics: New Perspectives on Theory and Research from Latin America. London: Ashgate, 2015, pp. 73-101.

ALVAREZ, Sonia. Engendering Democracy in Brazil: Women's Movements in Transition Politics. New Jersey: Princeton University Press, 1990.

ALVAREZ, Sonia. La (trans)formación de los feminismos y la política de gênero en la democratización en Brasil. In: Leon, Magdalena (Comp.). Mujeres y participación politica: avances y desafios en America Latina. Bogota: TM Editores, 1994, pp. $227-$ 289.

ÁVILA, Maria Betânia. Direitos sexuais e reprodutivos: desafios para as políticas de saúde. Cadernos de Saúde Pública, 2003, v. 19, n. 2, pp. S465-S469.

BANDEIRA, Lourdes. Fortalecimento da Secretaria Especial de Politicas para as Mulheres: avançar na transversalidade da perspectiva de gênero nas politicas públicas. Brasília: Cepal-SPM, 2005. 
BARSTED, Leila. O campo político-legislativo dos direitos sexuais e reprodutivos no Brasil. In: Berquó, Elza (Ed.) Sexo e vida: panorama da saúde reprodutiva no Brasil. Campinas: Ed. da Unicamp, 2003, pp. 79-150.

BERQUÓ, Elza (Ed.) Sexo e vida: panorama da saúde reprodutiva no Brasil. Campinas: Ed. da Unicamp, 2003.

BUGLIONE, Samantha (Ed.). Reprodução e sexualidade: uma questão de justiça. Porto Alegre: Themis: Assessoria Jurídica e Estudos de Gênero/Sergio Antonio Fabris Editor, 2002.

COELHO, Clair Castilhos. Saúde da mulher e o controle social no Brasil em tempos de neoliberalismo. Revista de Saúde Pública de Santa Catarina, 2008, v. 1, n. 1, pp. 54-64.

COOK, Rebecca. Estimulando a efetivação dos direitos reprodutivos. In: Buglione, Samantha (Ed.). Reprodução e sexualidade: uma questão de justiça. Porto Alegre: Themis: Assessoria Jurídica e Estudos de Gênero/Sergio Antonio Fabris Editor, 2002, pp. 13-60.

CORRÊA, Sonia. From Reproductive Health to Sexual Rights Achievements and Future Challenges. Reproductive Health Matters, 1997, v. 5, n. 10, pp. 107-116.

CORRÊA, Sonia; ÁVILA, Maria Betânia. Direitos sexuais e reprodutivos: pauta global e percursos brasileiros. In: Berquó, Elza (Ed.). Sexo e vida: panorama da saúde reprodutiva no Brasil. Campinas: Ed. da Unicamp, 2003, pp. 17-78.

COSTA, Ana Maria. Participação social na conquista das políticas de saúde para mulheres no Brasil. Ciência e Saúde Coletiva, 2009, v. 14, n. 4, pp. 1073-1083.

DINIZ, Simone. Materno-infantilism, feminism and maternal health policy in Brazil. In: Reproductive Health Matters, Vol. 20, №. 39, Maio de 2012, pp. 125-132. Disponível em: http://www.jstor.org/stable/41714707 Acesso em: 26/4/2016.

HTUN, Mala. Sex and the State: Abortion, Divorce and the Family under Latin American Dictatorships and Democracies. Cambridge: Cambridge University Press, 2003.

LIMA, Suzana Lopes. Saúde da mulher: a reformulação das práticas. In: Conferência Nacional de Políticas Públicas contra a Pobreza e a Desigualdade, 1., 2010, Natal. Anais... Natal: UFRN, 2010.

MATOS, Marlise; PARADIS, Clarisse. Los feminismos latinoamericanos y su compleja relación con el Estado: debates actuales. Íconos: Revista de Ciencias Sociales, 2013, n. 45, pp. 91-107.

MISCHE, Ann. Partisan Publics: Communication and Contention Across Brazilian Youth Activist Networks. Princeton, NJ: Princeton University Press, 2008. 
OSIS, Maria José Martins Duarte. Paism: um marco na abordagem da saúde reprodutiva no Brasil. Cadernos de Saúde Pública, 1998, v. 14, supl. 1, pp. 25-32. Disponível em: http://www.scielo.br/pdf/csp/v14s1/1337.pdf. Acesso em: 21 jul. 2014.

PETCHESKY, Rosalind Pollack. Direitos sexuais: um novo conceito na prática política internacional. In: Barbosa, Regina; Parker, Richard (Ed.). Sexualidades pelo avesso: direitos, identidades e poder. Rio de Janeiro: IMS/UERJ; São Paulo: Editora 34, 1999, pp. 15-38.

ROBERTS, Dorothy. Killing the Black Body: Race, Reproduction and the Meaning of Liberty. New York: Vintage Books, 1997.

ROCHA, Maria Isabel Baltar. Planejamento familiar e aborto: discussóes politicas e decisóes no Parlamento. In: Encontro Nacional de Estudos Populacionais, 14., 2004, Caxambu. Caxambu: Associação Brasileira de Estudos Populacionais, 2004.

SEGATO, Rita Laura. Gênero e colonialidade: em busca de chaves de leitura e de um vocabulário estratégico descolonial. e-cadernos ces, v. 18, 2012. Disponível em: <http://eces.revues.org/1533>. Acesso em: 30 set. 2016.

TORNQUIST, Carmen. Armadilhas da Nova Era: natureza e maternidade no ideário da humanização do parto. Revista de Estudos Feministas, 2002, v. 10, n. 2, pp. 483-492.

TORNQUIST, Carmen. Paradoxos da humanização em uma maternidade no Brasil. Cadernos de Saúde Pública, 2003, v. 19, n. 2, pp. S419-S427.

TORNQUIST, Carmen. Parto e poder: o movimento pela bumanização do parto no Brasil. Tese (Douturado em Antropologia Social) - Universidade Federal de Santa Catarina, Florianópolis, 2004.

VIEIRA, Elisabeth. Políticas públicas e contracepção no Brasil. In: Berquó, Elza (Org.). Sexo e vida: panorama da saúde reprodutiva no Brasil. Campinas: Ed. da Unicamp, 2003, pp. 151-196.

VILLELA, Wilza. Direitos sexuais e reprodutivos: afinal de que falamos? In: Buglione, Samantha (Org). Reprodução e sexualidade: uma questão de justiça. Porto Alegre: Themis: Assessoria Jurídica e Estudos de Gênero/Sergio Antonio Fabris Editor, 2002, pp. 81-92. 


\section{Documentos}

BRASIL. Ministério da Saúde. Pacto Nacional pela Redução da Mortalidade Materna e Neonatal. Brasília: MS, 2004a.

BRASIL. Ministério da Saúde. Politica Nacional de Atenção Integral à Saúde da Mulher: principios e diretrizes. Brasília: MS, 2004b.

BRASIL. Ministério da Saúde. Portaria n. 1.459, de 24 de junho de 2011. Brasília: MS, 2011a.

BRASIL. Ministério da Saúde. Gestões e gestores de políticas públicas de atenção à saúde da criança: 70 anos de história. Brasília: MS, $2011 \mathrm{~b}$.

BRASIL. Ministério da Saúde. Manual prático para a implementação da Rede Cegonha. Brasília: MS, s.d.

CASTILHOS, Clair. "Senhora presidenta, ouça as mulheres". Viomundo, 2 abr. 2011. Disponível em: <http://www.viomundo.com.br/politica/clair-castilhossenhora-presidenta-ouca-as-mulheres.html>. Acesso em: 4 abr. 2015.

DINIZ,Simone.EntrevistacomSimoneDiniz, por MarianaPortellaeAllanMonteiro. Coletiva, n. 14, maio-ago. 2014. Disponível em: <http://www.coletiva.org/site/ index.php?option $=$ com_k2\&view $=$ item\&layout $=i$ tem $\& i d=127 \&$ Itemid $=74>$. Acesso em: 17 abr. 2015.

GELEDÉS. Geledés - Instituto da Mulher Negra. Hoje na História, 18 de Maio de 1950, acontecia a Criação do Conselho Nacional de Mulheres Negras, no Rio de Janeiro. Portal Geledés, 18 maio 2014. Disponível em: <http://www.geledes.org. $\mathrm{br} /$ hoje-na-historia-18-de-maio-de-1950-acontecia-criacao-conselho-nacional-demulheres-negras-rio-de-janeiro/>. Acesso em: 19 abr. 2016.

NEGRÃO, Telia. Rede Feminista de Saúde alerta: A Rede Cegonha é retrocesso de 30 anos. Entrevista com Telia Negrão, por Conceição Lemes. Viomundo, 5 abr. 2011. Disponível em: <http://www.viomundo.com.br/entrevistas/rede-feministade-saude-rede-cegonha-e-um-retrocesso-de-30-anos-nas-politicas-de-generosaude-da-mulher-direitos-reprodutivos-e-sexuais.html>. Acesso em: 4 abr. 2015.

LOPES, F. WERNECK, J. Saúde da população negra: da conceituação às políticas públicas de direito. In: WERNECK, J. (org). Mulheres negras: um olhar sobre as lutas sociais e as politicas públicas no Brasil. Rio de Janeiro: Criola, s.d. Dispinível em: $\quad<$ https://pt.scribd.com/doc/207338601/Livro-Mulheres-Negras-JuremaWerneck $>$. Acesso em 9/10/2015.

OLIVEIRA, Fátima. Fátima Oliveira: Ministério da Saúde adoça a boca do Vaticano. Entrevista com Fátima Oliveira, por Conceição Lemes. Viomundo, 15 abr. 2011. Disponível em: <http://www.viomundo.com.br/entrevistas/fatima-oliveirams-adoca-a-boca-do-vaticano-ao-retomar-conceito-de-saude-materno-infantil. html>. Acesso em: 4 abr. 2015. 
ONU. Organização das Nações Unidas. Report of the Fourth World Conference on Women. New York: ONU, 1996.

RATTNER, Daphne. 10 anos de uma trajetória luminosa. Portal Aleitamento, 6 jan. 2011. Disponível em: <http://www.aleitamento.com/humanizacao-parto/ conteudo.asp?cod=163>. Acesso em: 4 abr. 2015.

RATTNER, Daphne. Da saúde materno infantil ao PAISM. Tempus Actas de Saúde Coletiva, 2014, v. 8, n. 2, pp. 103-108.

RATTNER, Daphne et al. ReHuNa: a Rede pela Humanização do Parto e Nascimento. Tempus Actas de Saúde Coletiva, v. 4, n. 4, 2010.

REHUNA. Rede pela Humanização do Parto e Nascimento. Carta de Campinas. Ato de fundação da Rede Pela Humanização do Parto e Nascimento. 1993. Disponível em: <http://www.ongamigasdoparto.com/2011/05/carta-de-campinas-ato-defundacaoda.html >. Acesso em: 4 abr. 2015.

REHUNA. Rede pela Humanização do Parto e Nascimento. Carta de Fortaleza. 2000. Disponível em: <http://www.ongamigasdoparto.com/2011/05/carta-defortaleza-2000.html>. Acesso em: 4 abr. 2015.

REHUNA. Rede pela Humanização do Parto e Nascimento. Manifesto da ReHuNa a favor das Casas de Parto. Portal Aleitamento, 2 fev. 2011. Disponível em: <http:// www.aleitamento.com/humanizacao-parto/conteudo.asp?cod=313>. Acesso em: 4 abr. 2015.

REHUNA. Rede pela Humanização do Parto e Nascimento. Portal ReHuNa, s.d. Disponível em: <http://www.rehuna.org.br/index.php>. Acesso em: 10 abr. 2015.

RFS. Rede Nacional Feminista de Saúde Direitos Sexuais e Direitos Reprodutivos. Dossiê Humanizacão do Parto. São Paulo: RFS, 2002.

RFS. Rede Nacional Feminista de Saúde Direitos Sexuais e Direitos Reprodutivos. Estatuto Social, 10 maio 2006.

RFS. Rede Nacional Feminista de Saúde Direitos Sexuais e Direitos Reprodutivos. Marcos da saúde das mulheres, dos direitos sexuais e direitos reprodutivos: ferramenta para a acão politica das mulheres. Porto Alegre: RFS, 2008.

RFS. Rede Nacional Feminista de Saúde Direitos Sexuais e Direitos Reprodutivos. Portal Rede Feminista de Saúde, s.d. Disponível em: <http://redesaude.org.br/ home/>. Acesso em: 10 abr. 2015.

WERNECK, Jurema. Saúde da população negra:passo a passo: defesa, monitoramento e avaliação de politicas públicas. Rio de Janeiro: Criola, 2010. 
WERNECK, Jurema. 'O governo Dilma está chocando o ovo da serpente': entrevista para o Viomundo, 9 fev. 2012. Disponível em: <https://www.viomundo.com.br/ denuncias/jurema-werneck-o-governo-dilma-esta-chocando-o-ovo-da-serpente. html>. Acesso em: 27 jun. 2018.

WERNECK, Jurema; IRACI, Nilza; CRUZ, Simone (Org.). Mulheres negras na primeira pessoa. Porto Alegre: Redes Editora, 2012. 


\author{
Capítulo 7 \\ OS MOVIMENTOS NEGRO E INDÍGENA \\ E A POLÍTICA DE SAÚdE E DE HIV/AIDS: \\ INSTITUCIONALIZAÇÃO E DOMÍNIO DE AGÊNCIA ${ }^{1}$
}

\author{
Vera Schattan Coelho \\ Adrian Gurza Lavalle ${ }^{2}$
}

\title{
1. Introdução
}

Quando um movimento social, como os movimentos negro ou indígena, demanda atenção à saúde para grupos historicamente marginalizados e mal servidos pela política pública setorial pode parecer simplesmente um reclamo projetado contra as autoridades públicas, cuja formulação depende basicamente de cálculos estratégicos em relação às possibilidades de se alcançarem objetivos específicos - denúncia, alocação de recursos, mudanças na operação ou redefinição de características fundamentais da política. Por sua vez, respostas

1 Este capítulo se baseia no relatório do estudo de caso escrito conjuntamente pelos coordenadores do estudo: Vera Coelho, Adrian Gurza Lavalle, Peter Spink e Mário Aquino Alves (Coelho et al., 2014a.) Agradecemos à nossa equipe de pesquisa: Márcia Lima, Laura Montinho, Flavia Rios e Silvia Aguião no tema de saúde da população negra e Juliana Rosalen e Alex Shankland, no tema de saúde indígena. Uma parte dos resultados foi reelaborada, complementada e desenvolvida para explorar su implicações do ponto de vista do debate contemporâneo da representação política. Agradecemos a Ricardo Fabrino os comentários a esse artigo, que indireta e posteriormente também beneficiaram este capítulo.

2 Os autores agradecem pelo financiamento do Centro de Estudos da Metrópole (CEM), processo n. 2013/07616-7, e da Fundação de Amparo à Pesquisa do Estado de São Paulo (Fapesp). As opiniões, hipóteses e conclusões ou as recomendações expressas aqui são de responsabilidade dos autores e não refletem necessariamente a visão da Fapesp. 
eventualmente favoráveis por parte de atores governamentais e estatais responsáveis pela política de saúde podem parecer apenas decisões políticas derivadas, de balanços de forças em determinada conjuntura e da proximidade - aliança até - ou distância entre o movimento demandante e as autoridades demandadas. De fato, essa compreensão dos atores como jogadores estratégicos é pertinente, pois demandas vocalizadas por movimentos são reclamos inscritos em estratégias de ação coletiva e atores estatais e governamentais orientam suas decisões por critérios políticos e não apenas "técnicos" ou de "interesse público". Porém, a formulação e vocalização de demandas coletivas, bem como sua recepção e processamento por parte das autoridades são capacidades e, enquanto tais, não surgem espontaneamente, nem emergem de modo imediato da vontade dos atores, mas são produzidas ou, melhor, politicamente construídas ao longo do tempo por processos de interação socioestatal (Gurza Lavalle, Houtzager, Castello, 2012). De um lado, reclamos públicos descansam em repertórios discursivos e estes, por sua vez, não nascem prontos, mas são decantações históricas. De outro, a recepção favorável das demandas e seu encaminhamento institucional supõem, por parte dos atores governamentais e estatais, a adesão - mesmo que parcial - dos argumentos que animam as demandas e a disponibilidade de instrumentos, dispositivos legais e instâncias de operação das políticas adequados para acolher tais demandas. Ambos, adesão e condições institucionais para transformar a recepção favorável em consequências mediante políticas são, igualmente, resultado de processos históricos de institucionalização tanto no plano das categorias cognitivas com que operam os agentes públicos da correspondente política quanto das ferramentas que tornam a operação e definição da política possível. Em fórmula mais sintética, embora mais abstrata porque expressa em registro teórico, sociedade civil e Estado são mutuamente constitutivos (ver o capítulo Gurza Lavalle, Carlos, Dowbor e Szwako, neste livro). Assim, os repertórios de 
estratégias e discursivos dos movimentos e a permeabilidade e capacidade de resposta do Estado perante as demandas que os primeiros the formulam são reciprocamente determinados e coproduzidos em processos de interação socioestatal. Quando esses processos levam a sedimentações institucionais que outorgam alguma vantagem a certos atores sociais e/ou alongam no tempo suas capacidades de atuação, produzem encaixes institucionais. Por sua vez, e ainda seguindo o argumento do capítulo introdutório, quando um conjunto de encaixes guarda articulação entre si em relação a uma determinada área de interesse dos atores sociais e essa articulação, a um tempo só, potencializa a capacidade de atuação dos segundos e lhes atribui legitimidade para agir, a sedimentação institucional adquire maior envergadura e configura um domínio de agência.

Analiticamente é possível assumir como pressuposto a mútua constituição e focar processos de institucionalização, quer dizer, situar o ângulo da análise na transformação das demandas dos movimentos, suas categorias práticas e canais de negociação em instituições (institucionalização). Nesse registro, as "instituições" são encaixes socioestatais entendidos em registro processual como sedimentações institucionais que favorecem a capacidade da ação ou agência dos atores sociais (e do Estado). Em direção oposta, também é possível fixar o olhar na decantação das estratégias de atuação e repertórios discursivos de tais movimentos em função dos processos de interação socioestatal em curso (Carlos, 2015a, 2015b). Este capítulo mira em ambas as direções, embora privilegiando a indagação geral do livro orientada para o diagnóstico sobre os processos de institucionalização no Brasil pós-transição. Entendemos que a institucionalização comporta graus diversos pela combinação de diferentes encaixes institucionais operando em distintos níveis de autoridade. Apenas quando a articulação entre encaixes configura um âmbito de atuação em que se reconhece a legitimidade para agir e para apresentar determinadas demandas 
mediante certos discursos ou a certos atores, configura-se um domínio de agência (ver o capítulo Gurza Lavalle, Carlos, Dowbor e Szwako, neste livro). Encaixes institucionais "avulsos" ou articulados em configurações de alcance modesto, todavia, também favorecem a agência dos atores sociais engajados na sua produção.

Com maior precisão, este capítulo combina uma política setorial que, embora propícia ao acolhimento de demandas de movimentos sociais (MS), distingue-se por ter definido padrões de institucionalização dissonantes com as demandas de movimentos distintivamente identitários, como o movimento indígena e o movimento negro. Com efeito, é conhecido que a política de saúde e, mais especificamente, o Sistema Único de Saúde (SUS) e o campo de ensino da medicina social cristalizam - com ajustes de monta porque mediados pelo conflito com os atores da medicina privada ou complementar e com as autoridades públicas - as demandas programáticas do movimento pela reforma sanitária (Escorel, 1998; Dowbor, 2012). A equidade e universalidade do acesso à saúde formam parte dessas demandas programáticas que restaram imbuídas nos princípios do SUS. Porém, o caráter universalista da política de saúde, sem dúvida elogiável em si, operou como circunstância adversa para grupos historicamente marginalizados, desprovidos de encaixes institucionais para disputar a política e portadores de reivindicações de inclusão avessos a fórmulas universalistas. Movimentos sociais operando em nome desses grupos historicamente desfavorecidos, como afrodescendentes e índios, passaram a reivindicar influência, nas decisões e no acesso a recursos, sob essa circunstância adversa, dentro da nova arena da política setorial.

O que vale para a política de saúde como um todo, adquire contornos enfáticos no caso da definição da política para HIV/Aids. Isso porque, nesse caso, o caráter universalista foi o resultado da vitória de atores contrários ao foco em grupos considerados de "alto risco”, adotado pelas políticas iniciais para lidar com a epidemia. 
Profissionais de saúde e organizações da sociedade civil ligados ao movimento LGBT se articularam para combater tentativas - tanto no discurso quanto na prática médica - de estigmatizar grupos específicos como sendo característicos do HIV/Aids. A epidemia de HIV/Aids atingiu o país no momento em que, após o regime militar, reconstruíam-se as instituições democráticas. O HIV/ Aids era uma doença inexistente, sem nome nem padrão conhecido, não havia protocolos médicos nem bases pré-existentes de conhecimento institucionalizado em lugar algum. Cabe lembrar que a resposta do Brasil ao HIV/Aids é reconhecida e aprovada internacionalmente como exemplo de sucesso na formulação e implementação de políticas. Com uma abordagem que envolve profissionais do setor saúde, atores da sociedade civil e movimentos sociais, ampliando a capacidade de resposta do Estado (Coelho et al., 2014b).

Conquistar influência na política não era, assim, tarefa fácil: não apenas reivindicações baseadas em raça ou etnia para o campo da saúde como um todo e, em especial, para os serviços de saúde relacionados ao $\mathrm{HIV} /$ Aids colidiam com o perfil universalista do setor, defendido pelos profissionais da saúde que se engajaram na reforma sanitária, mas tais reivindicações sequer estavam disponíveis no repertório discursivo dos movimentos negro ou indígena. O movimento negro feminista foi crucial na ampliação da agenda do movimento negro e na abertura de espaço para esse novo tipo de reivindicação e influência política. A criação do repertório discursivo e o processo a institucionalização fazem parte de um ciclo de trinta anos de interações socioestatais que culminou na edificação de um domínio de agência dentro do SUS, chamado de campo Saúde da População Negra. O movimento indígena, por sua vez, trabalhou para iluminar as desigualdades nas condições de saúde e os riscos crescentes a que estavam expostos tanto por suas condições de vida, quanto pela epidemia. Nesse movimento, a criação de um subsistema de saúde indígena testemunha o reconhecimento 
das especificidades associadas à distribuição territorial dos povos indígenas, tendo contribuído, ainda, para a compreensão do que são práticas interculturais e como podem ser implementadas. Tratou-se, ao mesmo tempo, em ambos os casos, de uma disputa pela definição inicial das linguagens de reivindicação por programas, protocolos epidemiológicos, preocupações profissionais e alocação de recursos burocráticos.

Neste capítulo, analisamos o processo histórico que permitiu aos movimentos negro e indígena disputar tanto sua incidência sobre a política de saúde quanto a reespecificação da política de HIV/Aids. Para isso, perguntamos como esses grupos historicamente desfavorecidos conquistam influência dentro de uma nova cena política, que apesar de progressista, ainda lhes era desfavorável. Os casos apresentados sintetizam parte dos resultados de um projeto de pesquisa realizado em vários países. Esse projeto investigou como os atores sociais (MSs e organizações da sociedade civil - OSCs) têm procurado influenciar políticas públicas nacionais voltadas para a redução da pobreza e da desigualdade. O estudo brasileiro (coordenado por Peter Spink, Mario Aquino e por nós) tratou da resposta do país ao HIV/Aids enfocando sua governança, que envolve atores da sociedade civil, e particularmente os movimentos LGBT, negro e indígena (Coelho et al., 2014a).

Para responder à nossa indagação foram realizadas entrevistas em profundidade com lideranças do movimento negro indígena e com informantes com conhecimento acurado desses atores sociais e de sua relação com o campo da saúde. Também foram examinados um conjunto amplo de documentos acessíveis ao público, a imprensa militante ou publicada por organizações dos movimentos, bem como a literatura acadêmica especializada. 


\section{O surgimento do HIV/Aids dentro da política de saúde}

O SUS foi consagrado pela Constituição de 1988 como o modelo de saúde pública que responderia ao estado de fragmentação, desorganização e subdesenvolvimento da atenção básica à saúde (Escorel, 1998). A proposta foi progressivamente amadurecida e abraçada pelos profissionais da saúde pública nos anos da ditadura e suas feições eram bastante mais ambiciosas do que a proposta aprovada na Assembleia Constituinte (Dowbor, 2012). Cogitouse a estatização do setor de saúde como um todo, mas a negociação com o setor de medicina privada ou suplementar nos trabalhos da Constituinte produziu um modelo misto: com amplo espaço para a medicina privada via o segmento dos planos de saúde - que viria a se mostrar extremamente pujante e rendoso (Baird, 2014) -, com um sistema público de ponta para padecimentos de alta complexidade e, por primeira vez na história do país, um sistema nacional descentralizado de atenção básica à saúde. Mesmo com esse perfil misto, os princípios básicos da proposta foram preservados e firmados. É responsabilidade do Estado garantir que a saúde pública seja universal quanto ao acesso, equitativa quanto ao trato ministrado á população e integral quanto ao cuidado da saúde. ${ }^{3}$ A defesa desses princípios e do SUS como projeto orienta a ação dos sanitaristas, do ativismo vinculado à saúde popular e dos trabalhadores do setor.

A arenabrasileira de HIV/Aids acompanhou o processo mais amplo de transformação do Estado e do setor de saúde, com ênfase significativa na descentralização (Wilson et al., 2008). Durante os anos 1980, os esforços para lidar com o HIV/Aids tiveram abordagem muito local, concentrada nos maiores conurbados do Rio de Janeiro e de São Paulo - cidades onde foram sediadas as primeiras ONGs-Aids e com presença significativa do movimento LGBT.

3 Os princípios também contemplam a descentralização e a participação cidadã. 
A mobilização em torno à Aids começou a adquirir visibilidade federal na segunda metade dos anos 1980, com a criação inicial de um programa consultivo nacional no âmbito do Ministério da Saúde para desenvolver uma política que combinasse dois princípios do SUS: universalização (principalmente o acesso gratuito a medicamentos e prevenção) e integração entre prevenção, cuidado e tratamento.

Em 1992, Lair Guerra, bióloga, assumiu o cargo de coordenadora do Programa Nacional (PN), atraindo diferentes setores da sociedade ao reformular a Comissão Nacional da Aids e dar início a negociações com o Banco Mundial para o financiamento de políticas para lidar com essa epidemia. Tratou-se de um momento de nacionalização ou centralização da política, que permitiu definir suas características básicas. Os acordos subsequentes com o Banco Mundial foram destinados a reformular a política $\mathrm{e}$ as relações interorganizacionais entre muitos atores dentro e fora do governo. Foi com os empréstimos do Banco Mundial ${ }^{4}$ que as ONGs Aids cresceram consideravelmente e se tornaram mais visíveis, como resultado dos vários fóruns e iniciativas que promoveram, bem como da sua associação com outras organizações e movimentos sociais. Depois que os empréstimos foram introduzidos, com recursos disponíveis para atividade de ONGs, as ONGs Aids começaram a trabalhar cada vez menos com o PN em nível nacional e cada vez mais com programas estaduais e locais, que eram mais próximos de suas atividades concretas (Coelho $e t$ al., 2014b).

Essas características da política de atenção básica à saúde e, especificamente, à epidemia de HIV/Aids, combinadas com bons resultados, cobertura e atendimentos, no primeiro caso, e técnicos e preventivos para lidar com a crise do HIV/Aids, ajudaram a

4 O primeiro empréstimo (Aids I) foi concedido em 1994, no valor de US\$ 160 milhôes; o segundo (Aids II) foi concedido em 1999, e foi de US\$ 165 milhões; o terceiro (Aids III), de 2003, foi de US\$ 100 milhões (World Bank, 2003). 
construir a imagem do SUS e, especialmente, do campo brasileiro do HIV/Aids como marcado por inclusão progressista, descentralização e, em alguma medida, participação e cogestão. Nas próximas seções, mostraremos como as reivindicações dos movimentos negro e indígena em nome das populações historicamente marginalizadas questionaram essa imagem e disputaram especificações da política de saúde que se chocaram contra esse modelo de inclusão.

\section{O movimento negro, a saúde da população negra e o HIV/Aids}

A institucionalização de um domínio de agência chamado pelos atores sociais engajados na sua construção e por autoridades públicas e gestores setoriais de campo Saúde da População Negra faz parte de uma história mais ampla, ocorrida ao longo de trinta anos, acerca do desenvolvimento da agenda política do movimento negro na área da saúde. Essa agenda, por sua vez, teria sido impossível sem a renovação, de meados dos anos 1970 até meados dos 1990, do próprio movimento negro e a criação do Movimento Negro Unificado (MNU), resultado do trabalho de um conjunto nacional de OSCs engajadas em questões de raça e gênero (Alvarez, 1990). Assim, a construção da saúde como uma questão importante para o movimento negro está intimamente relacionada à trajetória do movimento de mulheres negras. Mais: foi o movimento feminista negro o principal ator responsável por conferir centralidade à questão da saúde dentro do movimento negro e por fazer avançar as demandas do terreno da denúncia para o âmbito da proposição específica de políticas.

\subsection{Décadas de 1970 e 1980: renovação, saúde, raça e gênero}

No início da década de 1980, o movimento negro já percorrera uma longa trajetória. Havia um consenso cada vez maior entre ativistas e OSCs de que os racismos precisavam ser comba- 
tidos dentro de um marco de igualdade racial (Guimarães, 2012). Com isso, veio uma estratégia de mobilização nova e - na época arriscada: politizar publicamente a discriminação racial. Em 1978, ainda sob o regime militar, uma nova geração de OSCs negras e ativistas negros com experiência no movimento estudantil decidiu exigir o fim da discriminação racial e lançou o Movimento Negro Unificado (MNU), em uma reunião pública em uma das principais praças do centro de São Paulo, frente ao Teatro Municipal (Rios, 2014). Tradicionalmente, as OSCs negras tinham trabalhado a portas fechadas, organizando seminários, debates e atividades culturais. A nova estratégia de ir a público e politizar a discriminação racial continuaria sendo uma característica central do repertório brasileiro negro contemporâneo de protestos (Rios, 2012).

A partir de 1979, foram criadas seções estaduais do MNU em todo o país, houve financiamento de grupos de pesquisa para estudos afro-brasileiros em universidades públicas, e surgiu uma nova geração de OSCs negras na sociedade civil brasileira. ${ }^{5} \mathrm{~A}$ década de 1980 também assistiu à criação de várias organizações da sociedade civil feministas, seguidas por organizaçôes feministas negras (Damasco, 2009): Grupo de Mulheres Negras do Rio de Janeiro (1980), Nzinga Coletivo de Mulheres Negras (1983, Rio de Janeiro), Coletivo de Mulheres Negras (1984, São Paulo), Grupo de Mulheres Negras Mãe Andresa (1986, Maranhão), Grupo Mulher Maravilha - GMM (1989, Recife) e Centro de Estudos das Relações de Trabalho e Desigualdades - Ceert (1990, São Paulo). Especial menção merece o Instituto da Mulher Negra - Geledés, criado em São Paulo em 1988, pois liderou as primeiras

5 Entre eles, estavam: Centro de Estudos e Defesa do Negro de Pará - Cedenpa (1979, Pará), Associação Cultural Zumbi (1979, Maceió), Centro de Estudos da Cultura Negra - ÇCN (1980, Maranhão), Grupo de União e consciência Negra - Grucon (1981, Petrópolis), Instituto de Pesquisas e Estudos AfroBrasileiros - Apeafro (1981, São Paulo) e Centro de Estudos da Cultura Negra - Cecun (1983, Vitória), para citar alguns dos mais conhecidos. 
iniciativas em questões de saúde, apoiado pela OSC Criola, fundada no Rio de Janeiro (1992).

Durante os anos 1980, os movimentos negro e feminista negro tinham a mesma janela de oportunidades e enfrentaram restrições semelhantes. Por um lado, a anistia, a liberalização política e as possibilidades abertas pela Assembleia Constituinte (Alberti e Pereira, 2007); por outro, os preconceitos raciais dominantes e a falta de visibilidade do racismo como um problema grave que exigisse intervenção de políticas. Estratégias de mobilização semelhantes foram usadas por ambos os movimentos: revistas e jornais negros (p. ex. Revista Tição, jornal Versus, boletim Força Negra), estabelecimento de redes com jornalistas a fim de construir alianças, campanhas para aumentar a consciência racial e elevar a autoestima entre jovens negros, apresentações audiovisuais e slides, encontros e eventos (como a Semana do Negro).

No entanto, apesar dessas semelhanças, existem diferenças importantes. Inicialmente, havia pouco espaço para o movimento feminista negro dentro do movimento negro, tradicionalmente liderado por homens, fazendo com que parte da agenda de mobilização das feministas negras visasse situar o gênero junto à raça dentro do próprio movimento negro. Em registro positivo, o avanço da agenda feminista em nível internacional foi uma contribuição fundamental - uma agenda de reivindicações voltadas à saúde e direitos reprodutivos, que ajudou a reunir direitos civis básicos e políticas de gênero sob a perspectiva de raça. Contestando a visão de que a explosão demográfica era causa de subdesenvolvimento e, portanto, que o controle da natalidade deveria ser um objetivo fundamental da ajuda internacional, argumentou-se em favor do direito da mulher a decidir. A Primeira Conferência Mundial sobre as Mulheres foi realizada no México (1975) e, na década seguinte, aconteceram outras duas conferências importantes (Copenhague 1980; Nairóbi 1985), as quais, por sua vez, deram 
um estímulo fundamental às organizações de mulheres negras no Brasil (Ribeiro, 2008).

$\mathrm{Na}$ década de 1970, as reivindicações do movimento negro e seus grupos feministas tinham se baseado no tema da não discriminação e no aumento do acesso aos bens sociais. O tema dos serviços de saúde para pessoas negras tinha sido mencionado, mas não formou uma subagenda específica. Um documento escrito pelo MNU no ano de sua fundação permite apreciar o espírito do tempo, em que, de um lado, a afirmação racial e o combate à exclusão tornaram-se a nota distintiva (Guimarães, 2001, p. 132) e, de outro, a inclusão não aparece cifrada em termos de uma defesa específica de métodos ou ações a serem realizados pelo governo na área na saúde - ou em quaisquer outras áreas de políticas. Em sintonia com o cenário político do regime militar, a linguagem utilizada pelo movimento negro é de denúncia e de demanda indeterminada em relação a serviços e bens que caberia ao Estado providenciar.

Resolvemos juntar nossas forças e lutar pela defesa do povo negro em todos aspectos políticos econômicos, sociais e culturais, através da conquistas de: maiores oportunidades de emprego, melhor assistência à saúde, à educação e à habitação, reavaliação do papel do negro na sociedade [...] (Carta de Princípios do MNU, citado em Cardoso, 2002, p. 51).

Apenas no início da década de 1980 a agenda dos direitos reprodutivos se tornaria mais relevante para o movimento feminista no Brasil e, com isso, para os ativistas do movimento negro, estimulada em parte pelo aumento das propostas internacionais de esterilização como método de controle populacional dirigido aos pobres, afetando mais intensamente, em países como o Brasil, populações não brancas (Damasco, 2009). Por meio do movimento nacional de direitos humanos e, principalmente, na Conferência 
de Nairóbi em 1985, as mulheres negras começaram a fazer sentir sua presença, argumentando contra as políticas de controle populacional do governo brasileiro, principalmente os seus métodos de esterilização feminina (Werneck, Mendonça e White, 2000). Elas propuseram que o governo interviesse no controle populacional com métodos contraceptivos menos prejudiciais à saúde das mulheres (Roland, 1991; SNPDRMN, 1993).

Embora tenha se tornado mais relevante, a agenda dos direitos reprodutivos concentrou a atenção na questão da gravidez e do parto, bem como dos direitos a eles associados. O tema dos serviços de saúde, em si, ainda viria a ocupar um lugar central. Assim, em Mulher negra, escrito em 1985 por duas importantes ativistas negras, Sueli Carneiro e Thereza Santos, há referências explícitas à desigualdade entre mulheres e grupos raciais com base em um diagnóstico que levou em conta desigualdade em termos de renda, mercado de trabalho, educação e política, mas não há qualquer menção aos serviços de saúde. Além disso, durante a maior parte da década de 1980, a preocupação com os direitos reprodutivos relacionados a raça só era uma questão importante para as mulheres do movimento negro, e não para o movimento negro como um todo. Mesmo nos acontecimentos em torno à Constituição, o foco estaria nas questóes de direitos reprodutivos relativos à resistência aos programas de controle de natalidade e no apoio ao aborto, conforme atestado pela Convenção Nacional do Negro pela Constituinte, celebrada em 1986. Nos anos que se seguiram à Assembleia Constituinte, organizações de mulheres e ativistas negras trabalhariam no sentido de introduzir a saúde no centro do movimento negro como um todo e reforçar a discussão de serviços sobre saúde para a população negra. No início da década de 1990, não apenas o tema dos serviços de saúde ganhou centralidade no movimento negro, mas também se desenvolveu uma agenda de saúde para a população negra em que o governo era o alvo de 
reivindicações amplas de inclusão, bem como de demandas de políticas específicas.

É dentro desse novo cenário que as preocupações com o HIV/ Aids aparecem no movimento de mulheres negras, com projetos para divulgar informações sobre a prevenção e a orientação a jovens e mulheres de comunidades pobres. E a partir daquele momento, a cena internacional começaria a ter um papel fundamental. Tanto a Conferência de Pequim (1995), que gerou uma mobilização sem precedentes dentro do movimento feminista, quanto a Conferência de Durban de 2001, contra o Racismo, a Discriminação Racial, a Xenofobia e Formas Conexas de Intolerância, junto a vários eventos preparatórios, ${ }^{6}$ são amplamente reconhecidas como um divisor de águas na posição do governo brasileiro sobre a questão da raça e na projeção internacional do movimento negro brasileiro (Alberti e Pereira, 2007). Além de um marco para ações afirmativas e na área da saúde, a conferência de Durban foi uma plataforma para a visibilidade e a consolidação das relações entre raça, (homo)sexualidade e gênero, e outros temas transversais todos os quais eram particularmente relevantes para as políticas de saúde dedicadas ao HIV/Aids.

3.2 Décadas de 1990 e 2000: políticas de saúde para a população negra e HIV/Aids

A partir dos anos 1990, diferentes níveis de governo responderam às reivindicações do movimento negro e aos esforços de ONGs negras e, principalmente, feministas, tanto para negociar um espaço de políticas diferenciado - obter serviços de saúde para a população - como para introduzir distinções raciais em diferentes processos de políticas de saúde (Alvarez, 1990). Formular

6 A Conferência Mundial foi realizada em Genebra e a regional, no Chile, devido à recusa do governo brasileiro a ser o anfitrião (Telles, 2003). 
demandas raciais no campo da saúde não foi tarefa simples nem facilmente assimilável pelos atores tradicionais do campo da saúde pública, orientados por pressupostos universalistas sobre doenças, tratamentos e cura. Em primeira instância, a projeção de demandas públicas dependeu da construção da questão da saúde para as mulheres negras. Não se tratou apenas de chamar a atenção ou ganhar espaço dentro de uma problemática aceita como publicamente relevante, antes, foi mister construí-la e ganhar para ela notabilidade e aceitação entre especialistas.

Aqui, um novo recurso se tornou foco de mudança: os dados. Tornar as desigualdades raciais mais visíveis exigia informação, conforme tinha sido apontado nos Cadernos Geledés (Roland, 1991). Mais: a fundamentação técnica das reivindicações demandava acesso a dados sobre o estado de saúde da população negra, especialmente das mulheres, pois no discurso médico epidemiológico, a ausência de informação precisa e suficiente cancelava as possibilidades de debate e, consequentemente, comprometia as reivindicações do movimento feminista negro no nascedouro. Havia duas reivindicações: a primeira pedia a divulgação dos dados existentes, que poderiam ser desagregados por raça, e a segunda que foi ainda mais difícil de cumprir e ainda não é aceita de forma pacífica - era a inclusão do quesito "raça” e "etnia" em formulários de coleta de informações, registros e estatísticas da saúde pública, principalmente os relacionados a mortalidade e morbidade.

O processo variou de estado para estado e de município para município, mas o esforço geral foi semelhante. Em alguns casos, onde partidos e governadores progressistas governavam pela primeira vez depois da ditadura, o movimento negro conseguiu abrir algum espaço para seus representantes (como no caso das vagas para mulheres negras no Conselho Estadual da Condição Feminina de São Paulo), e até mesmo no estabelecimento de novas instituições públicas de nível estadual (como no caso do Conselho Estadual de 
Participação e Desenvolvimento da Comunidade Negra, também em São Paulo) (Rodrigues e Prado, 2010).

Houve alguns êxitos, mas também fracassos, e nem todos os primeiros resultados bem-sucedidos primeiros foram mantidos. Por exemplo, no final da década de 1980, o secretário municipal de Saúde de São Paulo era um conhecido médico e ativista do movimento pela reforma sanitária. Tendo ligações com movimento negro, ele aceitou a proposta de acrescentar informaçóes raciais aos registros básicos de saúde municipais. No entanto, a decisão, por si só, não seria suficiente se diretores e gestores de hospitais, médicos e enfermeiros, e pacientes não estivessem convencidos do valor dos dados (Bento, 2004). Portanto, como descreveu uma das mais reconhecidas ativistas feministas negras (Edna Roland):

[...] a gente bolou um processo de trabalho para que essa questão da raça e cor fosse implantada, visando três públicos diferentes. Um primeiro público que era constituído pelos gestores. Os diretores de hospital, de distritos de saúde. O pessoal que nós tínhamos de ganhar do ponto de vista conceitual. Demonstrando que a variável era relevante, que ela tinha um impacto sobre as estatísticas de saúde, sobre os indicadores de saúde. [...] Então foi a primeira etapa para a gente conquistar o pessoal que teria poder de gestão. Quem teria poder de fazer acontecer ou de boicotar. E depois então nós trabalhamos com profissionais e funcionários em geral. Nós fizemos alguns seminários ou oficinas de sensibilização. [...] a terceira etapa [...] foi um material destinado para a população em geral. Foi um folhetinho [...] 'Preto no branco'. É um folheto, muito simples, que a gente fez destinado à população usuária. Para explicar porque é que a Prefeitura estava colhendo informação sobre raça ou cor (Entrevista com Edna Roland). 
A iniciativa não sobreviveria à mudança de governo, e quase vinte anos se passariam até que os dados raciais começassem a ser coletados mais sistematicamente. Processos similares de negociação discursiva e confronto podem ser observados, no país, no repertório de estratégias e táticas de diferentes organizações do movimento negro parcialmente vinculadas. Para fazer avançar a agenda contra a discriminação no Estado, não apenas era necessário contornar as armadilhas dos argumentos da "democracia racial” (Guimarães, 2005; Telles, 2003), mas extrair as consequências da discriminação para o tratamento diferenciado de grupos em um campo de políticas animado por princípios universalistas a respeito de doenças, tratamentos e cura. Sem estratégias de persuasão como aquela descrita por Roland seria improdutivo levantar questões relacionadas à saúde das mulheres negras e da população negra como um todo, bem como remota a possibilidade de transformar essas questões em instrumentos de políticas. ${ }^{7}$

$\mathrm{Na}$ mesma época, começaram a aparecer os primeiros documentos sobre a saúde das mulheres negras. Em 1991, a primeira edição de Cadernos Geledés, publicada pela ONG recém-criada e que se tornaria muito influente, estabeleceu a plataforma do movimento feminista negro sobre serviços de saúde, começando com a afirmação de que a questão havia sido pouco explorada pelas ativistas. A publicação argumentava que o grau de desigualdade social e econômica sofrido pela população negra tinha consequências para muitos aspectos diferentes da vida, incluindo a saúde. Por isso, o grande desafio a ser enfrentado para tornar essas desigualdades mais visíveis era o de produzir dados sobre a situação de saúde da população negra, principalmente das mulheres negras, e obter acesso a eles. Essa dupla ênfase viria a se tornar um componente

Apesar desses esforços, anda hoje há informação por raça limitada em campos como os da medicina forense ou da oncologia (Şantos, Coelho, Araújo, 2013). 
crucial das estratégias das organizações da sociedade civil de mulheres negras no Brasil.

A primeira reunião das mulheres negras relacionada exclusivamente ao tema da saúde foi o Seminário Nacional de Políticas e Direitos Reprodutivos das Mulheres Negras, realizado na cidade de Itapecerica da Serra, na Região Metropolitana de São Paulo (1993). Ele visava à Terceira Conferência Internacional da ONU sobre População e Desenvolvimento, a ser realizada no Cairo, em 1994. Embora não fosse a primeira vez que o tema era posto na agenda pelas mulheres negras, pela primeira vez o debate era voltado totalmente à saúde.

A ativista negra Edna Roland já levantara o tema do HIV/ Aids e das mulheres negras em um artigo de 1991, que mais tarde se tornou o roteiro de um vídeo de curta metragem:

Com o recurso que a gente recebeu, nós produzimos então o vídeo 'Todos os dias são seus', que, de certa forma, é um marco na questão do tema mulher e Aids no Brasil. Porque foi o primeiro vídeo sobre mulher e Aids [...] se trabalhou com mulheres infectadas pelo HIV. E naquele momento [...] quando apresentava alguma pessoa infectada pelo vírus [...] pessoas apareciam contra a luz [...] não se mostravam [...] sempre ocultas. E 'Todos os dias são seus' é o primeiro vídeo feito no Brasil em que uma pessoa infectada pelo HIV fala de frente para a câmera. Então, essas mulheres, elas apareceram com um rosto, com uma história. Elas contavam as suas histórias (Entrevista com Edna Roland).

Porém, foi dois anos mais tarde, no seminário de Itapecerica, que ocorreram as duas primeiras grandes reflexões sobre o avanço da epidemia entre as mulheres. Durante muito tempo, tinha-se difundido a ideia de que mulheres em relacionamentos estáveis não eram um grupo "de risco", quando, na verdade, agora se mostrava que elas eram mais vulneráveis. A discussão se voltou ao papel su- 
bordinado das mulheres, principalmente em relação ao controle sobre seu próprio corpo e à consciência sobre a importância de usar preservativos. A conexão com a raça era tanto cultural - dentro da população negra - quanto socioeconômica, em relação às desigualdades sofridas pela população negra.

A precariedade do sistema educacional, a falta de informação e a de recursos materiais para a prevenção na rede pública de saúde já transformaram a Aids num grave problema para a população negra e pobre no país (Declaração de Itapecerica, SNPDRMN, 1993, p. 3).

As propostas de Itapecerica eram direcionadas à prevenção do HIV/Aids nos segmentos sociais mais pobres e, mais especificamente, nos setores negros da sociedade, mas se limitavam a questões de acesso à informação e educação (SNPDRMN, 1993). Só mais tarde surgiriam reivindicações por políticas setoriais específicas, por exemplo, a formação de trabalhadores do setor público na prevenção da Aids. Como afirmado por um dos ativistas negros que estava trabalhando com raça, saúde e HIV/Aids naquele período, "se trabalhava mais com a área de Educação, que era prioridade nesse momento. Nós tínhamos pouca gente ainda trabalhando com a Saúde" (Entrevista com José Marmo).

Em meados dos anos 1990, em grande parte graças aos esforços das organizações feministas negras, os temas de raça, saúde e HIV/Aids tinham finalmente chegado ao âmago do movimento negro, e a agenda de saúde feminista negra fora incluída na agenda do Movimento Negro como um todo. Neste caso, o marco foi a Marcha Zumbi dos Palmares (1995), cujo lema era "Contra o racismo, pela cidadania e a vida". A marcha foi organizada pelo Movimento Negro para comemorar o $300^{\circ}$ aniversário da morte de Zumbi dos Palmares, líder de escravos fugidos que se tornou símbolo nacional da resistência negra no Brasil colonial. Três ca- 
racterísticas do documento da Marcha Zumbi merecem menção. Em primeiro lugar, esse documento, que foi apresentado ao presidente Fernando Henrique Cardoso, coloca o tema dos serviços de saúde entre as principais reivindicações do movimento negro como um todo e propõe uma série de medidas, como parte de um programa para superar o racismo e a desigualdade racial. Em segundo lugar, o documento vai além de uma reivindicação abstrata por inclusão e igualdade, e exige políticas setoriais específicas para problemas de saúde específicos. Em terceiro lugar e com relação ao tema do HIV/Aids, o diagnóstico formulado no documento situa a Aids entre as prioridades de saúde do movimento negro e propõe medidas específicas. $\mathrm{O}$ quanto o repertório discursivo do movimento negro tinha mudado entre os anos 1970 e meados dos anos 1990 torna-se evidente no teor das demandas apontando para serviços e políticas públicas específicas. Por exemplo:

Adoção, no sistema público de saúde, de procedimento de detecção da anemia falciforme (nos primeiros anos de vida), hipertensão e miomatoses. [...] Viabilização de serviços específicos para anemia falciforme na área de hematologia, via Programa Nacional de Atenção às Hemoglobinopatias Hereditárias, medida inclusive já sugerida pela OMS. Tal Programa Nacional deverá dispor de habilitação técnica, política e ética para evitar, enfrentar e vencer as possíveis discriminações que poderão surgir em relação a portadores/as de AF ou do traço falcêmico. [...] Continuidade dos programas de prevenção e atendimento as DSTs/Aids (Marcha..., 1996).

A resposta do governo foi positiva e imediata. $\mathrm{O}$ documento foi formalmente reconhecido e se criou, por decreto, um Grupo de Trabalho Interministerial para a Valorização da População Negra com o objetivo de desenvolver políticas de reconhecimento da população negra. Fernando Henrique Cardoso foi o primeiro presi- 
dente do campo da oposição ao regime militar a ocupar, de fato, o cargo, e sua trajetória de esquerda o vinculava ao movimento pelos direitos humanos, que recebeu atenção durante seu mandato, como evidenciado pela criação do Programa Nacional de Direitos Humanos no ano seguinte da marcha. Nesse programa restou institucionalizado o compromisso do Estado brasileiro de combater a discriminação racial, bem como lineamentos de políticas para tanto - a criação de conselhos, por exemplo. Ademais, a presença de profissionais negros em importantes cargos de decisão no governo e sintonizados com a visibilização da discriminação racial longamente trabalhada pelo movimento negro, bem como o desenvolvimento vagaroso de um discurso elaborado em termos próprios do campo dos profissionais da saúde, antecedem aquilo que, de outro modo, pareceria uma súbita receptividade do Estado às demandas do movimento negro.

No plano estadual, as iniciativas para a prevenção do HIV/ Aids com foco na população negra também começaram a vingar. No Rio do Janeiro, o Projeto Arayê, da ABIA, foi o primeiro a adotar esse perfil.

Lembro que [...] provocamos uma situação de ser negro e viver com o HIV [...] Dá para ver os temas que incomodavam [...] a questão das mulheres negras que são lésbicas, dos homens negros que são gays [...]. foi a primeira vez que nós tivemos uma mesa, a nível nacional, com negros falando da sua vivência com o HIV, com o fato de ser negro e das questóes raciais que implicavam nessa questão. Inclusive o próprio Ministério da Saúde não via isso (Entrevista com José Marmo).

Trata-se, como salientado acima, de processos de negociação discursiva ou de construção social de fatos, tornada possível pelas estratégias de institucionalização do movimento negro. Introduziramse mudanças na política pública, mas a relação entre HIV/Aids e 
população negra continuou a ser controversa entre especialistas da área de saúde e da questão racial no país (Fry et al., 2007).

No primeiro governo Lula (2003-2006), os espaços para a inclusão do movimento negro e feminista na estrutura federal da administração pública se multiplicaram e se tornaram mais institucionalizados (Biroli e Miguel, 2016). As políticas públicas específicas com características raciais também aumentaram e ganharam feições mais ambiciosas. Conforme mostrado por Lima (2010), a institucionalização das demandas do movimento negro durante o governo de Fernando Henrique Cardoso operou majoritariamente no plano simbólico, mediante políticas de reconhecimento, mas foi tímida no plano redistributivo. Já nas gestões presidenciais de Lula, a institucionalização ganhou traços afirmativos de promoção da igualdade racial, cuja expressão institucional mais emblemática e de maior hierarquia foi, precisamente, a Secretaria Especial de Políticas de Promoção da Igualdade Racial (Seppir), criada no primeiro ano de governo e transformada em ministério no segundo mandato (Lima, 2010). O Conselho Nacional de Participação da Igualdade Racial (CNPIR), as Conferências Nacionais de Promoção da Igualdade Racial e o Plano Nacional de Promoção da Igualdade Racial, todos instituídos por primeira vez durante os mandatos do presidente Lula, também constituem sedimentações institucionais com escopo de atuação transversal ou multissetorial que cristalizam a um tempo só demandas do movimento negro e - não apenas compromissos manifestos em documentos, mas - capacidades concretas de atuação do Estado mediante órgãos.

A área dos serviços de saúde pode ser vista como uma das mais consolidadas em termos de programas e atividades visando à ação positiva e à inclusão da população negra (Carvalho, 2017). Conforme o diagnóstico geral dos traços distintivos da institucionalização nos governos FHC e Lula, e nas palavras de Maio e Monteiro (2005, p. 427): “o governo FHC manifestou uma atitude oscilante em matéria de políticas raciais. Em princípio, ele 
não julgou pertinente implantar programas específicos de saúde para a população negra [...]". Um ano após a toma de pose de Lula, a Seppir organizou o Primeiro Seminário Nacional de Saúde da População Negra, durante o qual foi instituído o Comitê Técnico de Saúde da População Negra. No ano seguinte (2005) instituiu-se o Programa de Combate ao Racismo Institucional e o Programa Estratégico de Ações Afirmativas: População Negra e Aids, seguidos da Política Nacional de Saúde Integral da População Negra (2007). À multiplicação de instâncias de definição e fiscalização de políticas de saúde para a população negra vieram associadas iniciativas de articulação à busca de efeitos multiplicadores, como o Programa Brasil-Afroatitude - Programa Intergado de Ações Afirmativas para Universitários Negros, impulsionado pela Seppir em parceria com o CNPIR, os ministérios de Saúde e de Educação, a Secretaria Especial de Direitos Humanos e com recursos do PN HIV/Aids. O Programa visava, a um só tempo, articular universidades com sistema de cotas nos seus processos de admissão, apoiar a permanência de cotistas mediante bolsas de pesquisa e induzir a produção de conhecimento sobre a relação entre raça e a epidemia, bem como sobre ações afirmativas (Seppir, 2005).

A magnitude do processo de institucionalização das reivindicações do movimento negro na política de saúde - inclusive quanto à epidemia HIV/Aids - dista de ser um conjunto de inovações desarticuladas; antes, configura um campo de ação em que lideranças, ativistas e OCSs do movimento negro adquiriram condições de disputar e incidir nos serviços de saúde destinados a atender a população negra. Trata-se de um domínio de agência reconhecido como tal por gregos e troianos sob a denominação campo da saúde da população negra. Entre as posturas críticas se reconhece que a "[...] construção do campo da saúde da população negra em anos recentes, [...] se vincula a processos mais amplos de inter-relação entre ativismo político e relação com o Estado, que transcendem a área da saúde" (Fry et al., 2007). Contudo, questio- 
na-se que nessa área consistem numa estratégia de racialização do campo com consequências indesejáveis: firmar a raça como clivagem política. Do ponto de vista dos ativistas historicamente engajados no processo de institucionalização, enfatiza-se a luta contra as iniquidades de raça como uma trajetória longa e ainda inconclusa, mas reconhece-se que esse campo é um fato novo. Como dito em um documento que discute participação e controle social para a igualdade em serviços de saúde para a população negra, escrito em 2007 por duas respeitadas ativistas que eram figuras centrais da ONG Criola:

A luta por melhores condições de vida e saúde da população negra é, como dissemos, antiga. Ainda assim, novos elementos têm sido agregados nos últimos tempos. Um dos principais foi a constituição de um campo de ação, pesquisa e política pública denominado saúde da população negra (Fernanda Lopes e Jurema Werneck, 2007, p. 4; destaque nosso).

Seja qual for a avaliação normativa acerca dos efeitos sobre a política de saúde e sobre a questão racial, do campo de saúde para a população negra, é fato que, conforme visto, ele é resultado de processo de longas interações socioestatais em que o movimento feminista negro desempenhou papel central. O desfecho desse processo de aproximadamente três décadas é a configuração de um domínio de agência que potenciou a capacidade de incidência do movimento negro sobre a política.

\section{Povos indígenas e HIV/Aids}

A relação entre os povos indígenas e a arena da política pública do HIV/Aids também é parte de uma história maior em que a saúde da população indígena pôde ganhar centralidade e status graças às garantias dos direitos para as populações indígenas previstas 
na Constituição de 1988, à mudança gradual do paradigma para serviços de saúde básicos integrais, à preocupação com a equidade nos serviços de saúde e ao crescente reconhecimento da diversidade - fatores decisivos para chamar atenção para as características específicas das questões de saúde indígenas e aumentar o número de programas e projetos para esses povos. Simultaneamente, seguindo-se à aceitação mais ampla das ONGs como prestadoras de serviços públicos, esse crescimento em programas e projetos abriria as portas para várias organizações ativistas indígenas e não indígenas se envolverem com questões de saúde e, como resultado, ocuparem importantes funções intermediárias. Nesse caso, diferentemente do que ocorreu no caso da saúde da população negra, os avanços e retrocessos no processo de institucionalização da agenda indígena, consubstanciados na disputa pela criação de um Subsistema de Saúde e de políticas específicas em relação ao HIV/ Aids para a População Indígena, foram bem-sucedidos em garantir a sedimentação do subsistema, mas não encontraram no processo de implementação meios que assegurassem a consolidação de uma política no campo da epidemia.

4.1 Décadas de 1980 e 1990: coordenação dos povos indígenas e a questão da saúde

O início da década de 1980 assistiu à construção de uma nova agenda de saúde pública no Brasil, conforme mencionado, com menos ênfase no controle vertical das doenças endêmicas e mais atenção à construção de um sistema que integrasse serviços básicos de saúde e fosse fortemente sustentado pela noção de "direito à saúde". Os direitos estavam na agenda de outros campos, e também haveria um aumento da participação ativa de antropólogos no apoio às reivindicações dos povos originais. Em 1979, foi criada a primeira organização indígena de âmbito nacional, a União das Nações Indígenas (UNI), que estabeleceu conexões com 
ONGs internacionais, como a Oxfam, as quais estavam trabalhando em agendas relacionadas a direitos e pobreza. Seus líderes, entre eles, Mário Juruna (Xavante), Angelo Kretan (Kaingang) e Raoni (Txukarramãe), viriam a se tornar importantes referências étnicas e políticas nos cenários nacional e, até mesmo, internacional.

Em 1986, nos preparativos para a Assembleia Constituinte, formou-se a Coordenação Nacional de Tribos Indígenas e a Constituição, que incluía muitas organizações, entre elas a UNI, com o objetivo de assessorar e supervisionar o trabalho da Assembleia Constituinte em questões de direitos indígenas. No mesmo ano, a Oitava Conferência Nacional de Saúde foi um espaço para o primeiro encontro formal entre os Movimentos de Saúde e Indígena, e expressou a reivindicação de que o SUS desse atenção específica aos direitos e às necessidades de saúde dos brasileiros indígenas. Apesar de suas muitas divisões internas e de haver cerca de duzentos povos diferentes, o movimento indígena permaneceu mobilizado durante todo o período da Assembleia Constituinte. Combinando uma rara demonstração de unidade com o apoio de uma ampla rede de grupos da sociedade civil brasileira e internacional, o movimento indígena conseguiu garantir que direitos à terra e às culturas indígenas fossem consagrados na Constituição, bem como assegurar o reconhecimento dos povos indígenas como cidadãos plenos (Cornwall, Ronano e Shankland, 2009).

Ao se passar dos anos 1980 aos 1990, as questões indígenas ganhariam ainda mais impulso no cenário internacional, principalmente na América Latina. Em 1993, a ONU anunciou a Década Mundial dos Povos Indígenas (1995-2004), que tinha entre seus objetivos o fortalecimento da cooperação internacional para enfrentar os desafios de saúde de diferentes povos. No mesmo ano, a Organização Pan-Americana de Saúde (OPAS) propôs uma reflexão mais cuidadosa sobre a saúde e o bem-estar dos povos indígenas das Américas. Em um seminário realizado em Winnipeg, no Canadá, representantes de povos e governos de 18 
países propuseram a "Iniciativa pela Saúde dos Povos Indígenas", cujos objetivos eram: incentivar os países a detectar e monitorar desigualdades com base em etnia e estabelecer programas e processos, implementar uma abordagem global à saúde, reconhecer o direito dos povos indígenas à autodeterminação e a participar de decisões políticas e processos de implementação de políticas que afetem suas vidas (San Sebastián e Hurtig, 2007). Com base nessas diretrizes, a OPAS aprovou a Resolução CD37.R5, para orientar suas próprias atividades, bem como as dos seus estados-membros, em clara demonstração de o quanto os conceitos de equidade, diversidade e participação haviam se tornado importantes nos anos 1990 (OPAS, 1997).

Nesse cenário de redefinição da saúde, expansão de direitos, mobilização e crescente reconhecimento internacional, diversos atores desempenharam papéis centrais, contribuindo para forjar uma nova abordagem ao $\mathrm{HIV} /$ Aids nas comunidades indígenas. $\mathrm{O}$ estudo de caso tratou mais especificamente do trabalho feito nesse sentido por três ONGs: duas não indígenas (Saúde Sem Limites e Iepé $)^{8}$ e uma indígena (Apina), interrogando questões relacionadas a comunicação intercultural e acesso a serviços. Neste capítulo exploramos mais detalhadamente a experiência da Apina, fundada pelo povo Wajãpi do Amapá, no enfrentamento dos desafios interculturais na área do HIV/Aids. Com esse estudo buscamos recuperar as condições que permitiram o avanço do subsistema de saúde indígena discutindo como elas têm afetado a capacidade

8 A Saúde Sem Limites (SSL) foi fundada em 1994, por médicos e antropólogos, para trabalhar com questóes de saúde entre populações indígenas e tradicionais. Ela desenvolve projetos e atividades nos estados do Acre, Amazonas e Pernambuco. O Instituto de Pesquisa e Formação Indígena (Iepé) foi fundado em 2002. Trabalhando em conjunto com os Wajãpi desde 1991, principalmente em relação a questões de demarcação de terras e direitos territoriais e de saúde, desenvolve programas de formação para jovens e adultos escolhidos por suas comunidades para atuar como agentes e/ou representantes comunitários. 
desse subsistema de responder de forma efetiva às demandas da comunidade indígena.

\subsection{Políticas de saúde para a população indígena e HIV/Aids}

No final dos anos 1980 e durante os 1990, houve um aumento significativo na incidência de HIV/Aids entre os povos indígenas, principalmente aqueles que viviam ou viajavam para áreas urbanas e fronteiriças. ${ }^{9}$ Inicialmente, a Fundação Nacional do Índio (Funai), ${ }^{10}$ agência do governo federal, esteve à frente das ações para combate à doença, antes de passar a articular as atividades com o recém-criado PN Aids do Ministério da Saúde. Em 1991, a Fundação Nacional de Saúde (Funasa) foi formada como agência executiva do Ministério da Saúde para assumir a responsabilidade pela saúde indígena. Em 1992, criou-se o primeiro Distrito Sanitário Especial Indígena, na área do povo Ianomâmi, do norte da Amazônia, como um esforço para deter os elevados índices de mortalidade resultantes da malária e outras doenças infecciosas que estavam ocorrendo devido a invasões de garimpeiros ilegais em busca de ouro na região.

Em 1994, equipes do PN Aids começaram a promover a prevenção do HIV/Aids e a mobilizar as comunidades indígenas para que pressionassem por melhores condições de saúde. ${ }^{11}$ A presença de trabalhadores de saúde pública e antropólogos nas aldeias, além das verbas disponíveis para pequenos projetos comunitários por meio do programa Aids I do Banco Mundial e das reunióes

9 Entre 1987 e 1999, foram identificados 33 casos de Aids entre indígenas.

10 Até o início da década de 1990, todas as ações relacionadas aos povos indígenas eram geridas exclusivamente pelo Ministério da Justiça, por meio da Fundação Nacional do Índio (Funai), criada em 1967 para substituir o Serviço de Proteção ao Índio, de 1910. Os povos indígenas não eram reconhecidos como cidadãos plenos e a Funai era sua guardiã coletiva institucional.

11 Entrevista com Marcos Pellegrini, então coordenador do programa de HIV/Aids do Ministério da Saúde para populações indígenas. 
macrorregionais estabelecidas pelos profissionais de saúde federais, abriu espaços políticos para os líderes indígenas locais reivindicarem seus direitos a serviços de saúde.

Dois exemplos de reuniões macrorregionais que aconteceram no período se destacam: o Primeiro Encontro de Agentes Indígenas de Saúde na Amazônia Brasileira (AM) e a Primeira Oficina Macrorregional de Estratégia, Prevenção e Controle das DST/AIDS para as Populaçôes Indígenas das Regióes Sul, Sudeste e Mato Grosso do Sul, ambos em 1997. Elas reuniram agentes de saúde e lideranças indígenas do Amazonas e de outros estados para discutir a questão da saúde e da formação, e incluíram problemas de doenças sexualmente transmissíveis, Aids e alcoolismo. Os eventos foram fundamentais para consolidar um movimento de saúde indígena coletiva e levaram, no mesmo ano, à apresentação do Projeto de Lei 63, que propunha a criação do Subsistema de Saúde Indígena.

Os argumentos em defesa de um Subsistema de Saúde Indígena se baseavam na necessidade de melhorar a capacidade operacional geral do sistema de saúde para chegar a comunidades isoladas, aumentar a capacidade de resposta às especificidades das diferentes culturas tribais indígenas e superar o racismo entre as autoridades de saúde e municipais. Como resultado, criou-se, em 1999, uma estrutura especial e, em alguma medida, isolada dentro do SUS: o Subsistema de Atenção à Saúde Indígena, sob responsabilidade direta da Funasa. ${ }^{12}$ Os territórios de saúde seriam chamados de Distritos Sanitários Especiais Indígenas (DSEIs), e deveriam refletir o fato de que os territórios indígenas iam além de limites municipais e, às vezes, até estaduais. No total, havia 34 distritos especiais, cada um supervisionado por um conselho do

12 Portaria Administrativa n. 852 (Funasa), 30 de setembro de 1999. A população indígena era de 510.812 pessoas e a despesa per capita com saúde, $\mathrm{R} \$ \mathbf{9 8 7 , 1 0}$ (USD 590.00). 
qual, por lei, metade dos membros deveria representar os usuários de serviços de saúde indígenas.

A Funasa terceirizou a gestão dos DSEIs a vários grupos da sociedade civil, incluindo não apenas ONGs, departamentos universitários e grupos missionários, mas também as próprias organizações do movimento indígena. $\mathrm{O}$ financiamento Aids $\mathrm{II}^{13}$ do Banco Mundial apoiou uma série de projetos de prevenção e de formação de multiplicadores (agentes de saúde indígenas, professores, líderes), em colaboração com organizações indígenas e organizações parceiras indigenistas.

Muitas delas se reuniriam na Terceira Conferência Nacional de Saúde Indígena, realizada em 2001, na qual os delegados indígenas propuseram a criação de "estratégias de prevenção e controle das doenças sexualmente transmissíveis, síndrome de imunodeficiência adquirida (Aids) e alcoolismo voltadas para as comunidades indígenas".

Dois projetos relacionados aos wajãpi receberam financiamento do programa Aids II: um era gerido pelo IEPE e o outro - "Prevenção de Doenças Sexualmente Transmissíveis em Terras Indígenas Wajãpi" - contava com a participação do Apina na elaboração (consulta à comunidade), na implementação (organização de oficinas, fornecimento de infraestrutura) e na avaliação do projeto. O Apina (Conselho das Aldeias Wajãpi) foi fundado em 1994 e reúne líderes de todos os grupos locais que vivem atualmente em território wajãpi (Terra Indígena Wajãpi/TIW). ${ }^{14} \mathrm{Em}$

13 O programa Aids II foi aprovado em 1998 e executado entre 1999 e 2003, e era voltado à expansão territorial e, principalmente, à feminização da epidemia.

14 O Apina reúne: "No nosso documento de 2005 nós já explicamos que não existe um chefe só de todos os Wajãpi. Nós não somos um grupo só, somos muitos grupos. Cada grupo familiar tem um chefe, e um chefe não manda no outro chefe. Nenhum chefe representa todos os Wajãpi. Nós sabemos que para conversar com os não índios, principalmente com o governo, precisamos ter representantes. Por isso nós criamos uma organização para representar os Wajãpi na frente dos não índios: o Conselho das Aldeias Wajãpi - Apina. (Apina, 2007). 
ambos os projetos, agentes comunitários de saúde indígenas receberam formação adicional relativa a doenças sexualmente transmissíveis e Aids.

Os wajãpi tinham demonstrado grande resistência a uma tentativa anterior da Funasa de introduzir o preservativo como método preventivo. Eles acreditam que há um princípio vital (-ã) ${ }^{15}$ que é responsável por dar vida ao corpo e encontra sustentação para sua circulação nos fluidos corporais. Na concepção sociocosmológica dos wajãpi, como o esperma é um desses fluidos, se ele for mantido em um recipiente, como um "preservativo", ele fará com que seu dono fique fraco, já que seu princípio vital será contido. Outros riscos estão ligados ao descarte do preservativo: se ele for jogado na floresta, no rio ou na terra, o dono do esperma corre o risco de o seu princípio vital ser apropriado pelos diferentes -jara, os donos de outras esferas que compóem o universo wajãpi. Do mesmo modo, ao ser enterrado ou amarrado, o preservativo provoca um "sufocamento" do princípio vital da pessoa sob a terra, e quando é jogado no lixo de pessoas não indígenas, há medo de que o preservativo seja queimado, o que causaria queima do princípio vital da pessoa. Para os wajãpi, cada um desses riscos implica algum tipo de doença específica, e pode mesmo levar à morte (Rosalen, 2005).

Para entender e superar as contradições entre as suas próprias representações e práticas e as que vêm da biomedicina ocidental, uma série de atividades de conscientização foi organizada por uma equipe de especialistas do Iepé. Entre eles estavam um enfermeiro (na época, um coordenador técnico do Programa de Saúde Wajãpi, que tinha ampla experiência de trabalho entre tribos indígenas), uma antropóloga (que tinha pesquisado e tra-

\footnotetext{
15 "O princípio vital não é um atributo exclusivo dos seres humanos, ao contrário, onde reside vida, inclusive no homem, é porque o - ã se faz presente. Nas pessoas, este princípio é responsável por fornecer potencialidades de ação, como falar (materializada na palavra), olhar, ouvir, andar, pensar etc." (Rosalen, 2005).
} 
balhado com o grupo indígena), e uma linguista (que também pesquisava e trabalhava com educação indígena no grupo).

Esse breve exemplo mostra a complexidade das representações de saúde e os limites de políticas genéricas de prevenção quando se lida com essas diferentes configurações socioculturais. Também foi importante produzir textos que fossem apropriados e pudessem ser compreendidos pelos wajãpi. No processo, a equipe conseguiu contribuir, ainda que de forma preliminar, para a geração de novas explicações que pudessem estabelecer pontes entre as contradições culturais presentes, e abriu espaço para a formação de técnicos de saúde atentos às dinâmicas socioculturais. Foi fundamental constatar que, assim como é necessário encontrar maneiras de traduzir programas de prevenção para essas populações, também é preciso explicar à comunidade de especialistas em HIV/ Aids por que essas populações têm dificuldade de aceitar as recomendações do programa.

Em 2004, houve uma mudança importante e dramática na orientação geral do subsistema de saúde indígena como um todo. Por várias razões ligadas à política e à distribuição de recursos, uma série de organizações ligadas aos movimentos indígenas se tornou alvo de processos e de uma onda de auditorias financeiras e intervenções que levantavam dúvidas sobre o uso que faziam das verbas públicas. Isso, por sua vez, levou a uma série de medidas de recentralização, com a maioria dos serviços sendo reassumida pela Funasa ou transferida para outras ONGs ou municípios locais (Cornwall, Romano e Shankland, 2009). ${ }^{16}$

Em setembro de 2004, a Portaria n. 16 foi aprovada pela Funasa, ${ }^{17}$ estabelecendo uma nova parceria com o Programa

16 É importante registrar que os procedimentos e regulamentos relativos às finanças públicas são extremamente complexos e, muitas vezes, mesmo para governos municipais bem estabelecidos, é difícil ter as contas aprovadas.

17 Portaria SE/MS/Funasa n. 16 de 28 set. 2004, que aprova a descentralização de dotações orçamentárias e recursos financeiros objetivando o apoio às ações de 
Nacional de Aids, especificando que atividades de prevenção e tratamento deveriam ser assumidas por equipes oficiais dos Distritos Sanitários Especiais Indígenas, e não mais por ONGs. Na prática, isso significou a retirada oficial do apoio anteriormente previsto à participação ativa de comunidades indígenas e OSCs sociais em questões de saúde indígena.

Esse processo de centralização não comprometeu completamente a participação de representantes indígenas (em seu papel de usuários do serviço) na direção, no desenvolvimento e na avaliação das ações de saúde. Felizmente, havia outras linhas que poderiam ser seguidas, como o uso da garantia legal de participação em Conselhos Locais, Distritais e Nacionais de Saúde. Porém, também nesses espaços existem dificuldades, pois há pouco respeito e compreensão pela natureza do sistema político wajãpi e sua recusa em aceitar um líder único:

Eles querem que o representante tome decisões. Nós não reconhecemos um chefe. Cada grupo, cada wanã, tem seu próprio chefe. Quando uma decisão deve ser tomada todos os chefes se reúnem e decidem. Um chefe não pode tomar uma decisão pelos outros (Pesquisadores Wajãpi, 2009).

Por fim, a Portaria n. 16 representou uma mudança importante na orientação do subsistema de saúde indígena e demonstrou a fragilidade de conquistas que pareciam institucionalmente consolidadas. Assim embora a equipe não indígena de saúde, agora encarregada dos serviços de HIV/Aids nos Distritos Sanitários, esteja seriamente comprometida com prevenção e tratamento, por vezes pouco compreende sobre as especificidades e as complexidades que o uso de preservativos evoca em comunidades como a

saúde pertinentes a execução do Projeto de Implantação do Programa DST/Aids nos 34 Distritos Sanitários Indígenas. 
dos wajãpi. Adicionalmente, esses profissionais tendem em muitas situações a não ver necessidade de envolver os povos indígenas na implementação do programa.

\section{Institucionalização: um processo que está longe de ser linear}

Os nossos dois casos mostraram sinais de sucesso no aumento da agência de grupos sociais historicamente marginalizados e setores sociais vulneráveis, ao permitir que atores coletivos atuassem institucionalmente em seu nome e definissem regras, diretrizes e políticas favoráveis para esses grupos. Esses avanços exprimem o resultado de longos processos históricos de sedimentação institucional que legaram encaixes mediante os quais se tornou possível disputar com algum sucesso a construção de agendas públicas de combate à discriminação racial, assim como de políticas para implementá-las. Também tornaram possível a edificação de um subsistema de saúde para a população indígena. A magnitude das mudanças na saúde tanto dentro da agenda de demandas do movimento negro quanto na política setorial é digna de nota. A saúde foi deslocada de um assunto marginal a uma posição central dentro das demandas do movimento, da área da natalidade e dos direitos reprodutivos ao campo da atenção a saúde como um todo, de reclamos gerais de acesso a serviços de saúde como um direito a demandas de políticas públicas específicas disputadas em linguagem especializada. Já a construção do campo da saúde indígena envolveu a reivindicação de territórios próprios, que muitas vezes se sobrepõem aos limites municipais e estaduais, bem como a construção de pontes entre as práticas e os significados mobilizados pelas diferentes culturas envolvidas na implementação do subsistema.

Sem dúvida, os movimentos sociais feminista e negro, e indígena são agentes sine qua non desses processos, e seu protagonismo demandou enorme mobilização social, além de inteligência, 
comprometimento, perseverança e paciência histórica de ativistas e lideranças. Porém, seria equivocado pressupor que eles são $o$ sujeito desses processos, como se a institucionalização fosse "simplesmente" resultado de sua mobilização e da pressão bem-sucedida sobre as instituições, ou produto de um plano consciente, munido de uma estratégia bem traçada do início ao fim. Antes, são longos processos de interação socioestatal que levaram a sedimentação de encaixes diversos (colegiados consultivos, programas, instituições participativas, órgãos públicos, ministérios) e a construção de um discurso passível de ser assimilado por diversos agentes estatais (burocracias de diversos níveis). Os encaixes, por sua vez, fomentaram a continuidade da interação com burocratas, mas também com políticos (governos, partidos) e atores societários (ONGs, organizações populares) - inclusive interestatais (ONU, OPAS). De fato, a própria agenda de demandas dos movimentos na área de saúde é uma construção política, cujas feições finais seriam inteiramente inconcebíveis, mesmo para os atores mais otimistas desses movimentos, apenas um par de décadas atrás.

$\mathrm{O}$ processo de institucionalização está longe de ser linear. Não apenas porque conferir estatuto institucional a agendas, interesses e valores dos movimentos sociais admite uma variedade considerável de expedientes empíricos, assemelhados analiticamente mediante o conceito "encaixe", mas porque a articulação de tais encaixes produz configurações diversas, chegando a se cristalizar em estruturas de intermediação corporativas ou em configurações menos estáveis e potentes aqui denominadas domínios de agência ou, ainda, em articulações de alcance mais modesto.

No caso do domínio de agência da saúde da população negra e de articulações mais modestas como as da saúde indígena, vimos como a institucionalização é muito mais lenta e incerta, e menos articulada, do que muitos gostariam. Na verdade, poderíamos argumentar que não existe uma escada rolante mágica que ligue o passado ao presente, nem as inúmeras disputas em lugares 
e momentos específicos (micro) a sua sedimentação institucional em dispositivos que operam em níveis de autoridade política mais elevados e de maior cobertura territorial (meso ou macro). As feministas negras começaram a trabalhar com a saúde e os direitos reprodutivos em meados dos anos 1970, fundaram sua primeira OSC na década de 1980 e levaram duas décadas para trazer a saúde mais próxima ao centro da agenda do movimento negro. No início, não havia reivindicações nem recomendações de políticas claras. Em princípio existia apoio potencial passível de ser atraído da aliança mais ampla com o movimento feminista, mas, mesmo assim, as feministas negras enfrentaram um duplo desafio, como mulheres e como afrodescendentes. Não havia espaço para reivindicações de gênero entre os ativistas negros do sexo masculino, e existiam muito poucos dados básicos de saúde com base em raça para mostrar a justeza das reivindicações feministas negras. Nos primeiros tempos do HIV/Aids, a posição médica, científica e moral progressista era contrária a qualquer tipo de discriminação: a epidemiologia era biológica. Defender as especificidades das mulheres negras era um desafio tanto à auto-organização, à autodescoberta, ao autoconvencimento quanto ao desenvolvimento de um discurso público plausível e ao convencimento da opinião pública e do governo.

$\mathrm{O}$ caso do movimento indígena também testemunha o longo tempo que foi necessário para construir visões alternativas e estabelecer pontes entre as diferentes práticas culturais. Mostra, ainda, o quanto esses avanços são vulneráveis a ações do governo. O movimento tinha sido capaz de estabelecer relações complexas com partidos políticos e vínculos com diferentes organizações globais, nacionais e regionais (Oxfam, Fundação Gaia, Health Unlimited, CIMI, CPI e outros), bem como com diferentes partes do Estado nos planos federal, regional e municipal. Por meio de seu envolvimento em encontros regionais e nacionais, e também em fóruns, conselhos e conferências mais institucionalizados, o 
movimento indígena e suas organizações acabaram por se envolver no processo de formulação e implementação de políticas de saúde e transformar, ao menos parcialmente, a política de HIV/Aids. Esses avanços não foram suficientes, no entanto, para fazer páreo às consequências de um novo padrão de procedimentos e controles contábeis instituído pelo governo. Há, todavia, um ganho importante que permanece: a institucionalização do subsistema de saúde indígena.

As trajetórias da institucionalização são igualmente não lineares, alternando do plano local para o estadual e o nacional, lógicas de descentralização e recentralização, e modalidades de encaixes institucionais diversas: encontros, comissões, conferências, conselhos e outros órgãos colegiados; cargos administrativos, posições de administração ou implementação local da política ou de assessoria pela disposição de expertise rara em áreas emergentes como a da política de HIV/Aids; órgãos (inclusive com estatuto ministerial), programas, políticas e seus instrumentos Mais: o caso do movimento negro mostra que encaixes aparentemente triviais podem encerrar potenciais inesperados. Se, conforme elaborado por Gurza Lavalle, Carlos, Dowbor e Szwako (neste livro), encaixes institucionais constituírem salvaguardas com alguma densidade institucional - obrigatoriedade e estabilidade - que favorecem os interesses dos atores que os introduziram, então a inscrição do quesito raça nos formulários do sistema de atenção básico à saúde revelou-se, como instrumento de política, um encaixe de natureza cognitiva que permitiu ao movimento negro mostrar aos profissionais da saúde a relação entre raça e padrões de morbidade.

Enfim, as demandas pela diferenciação de campos específicos de políticas públicas foram bem-sucedidas: o campo da saúde da população negra e o Subsistema de Atenção à Saúde Indígena são cristalizações institucionais de alto nível de autoridade; contudo, apenas no primeiro caso a institucionalização veio acompanhada da constituição de um domínio de agência estável que preserva a 
posição dos atores vinculados ao movimento negro. Certamente, a agenda de saúde do movimento negro encontrou seu lugar dentro da política de saúde setorial, assim como dentro da arena política do HIV/Aids, mas esta não é, de maneira alguma, uma "luta concluída”. Não apenas por que há muito a ser feito, mas pelo que parece ser, no cenário da política nacional, a finalização do período favorável à institucionalização dos interesses e agendas desses atores. Outros atores de perfil distinto, é claro, avançam hoje na institucionalização de seus interesses e agendas.

Os achados evidenciam que o período pós-transição foi favorável à institucionalização de agendas, interesses e valores dos movimentos sociais negro e indígena e, durante esses anos, processos de interação socioestatal inscreveram no Estado não apenas a agenda de direitos de grupos tradicionalmente marginalizados, mas definiram políticas de saúde sensíveis às especificidades desses grupos. Como o grau de institucionalização da política de Saúde da População Negra e do Subsistema de Saúde Indígena é distinto, sendo o segundo mais modesto e a primeira, um domínio de agência, parece razoável pensar que essa terá maior estabilidade e que o movimento negro estará em melhores condições de defender sua posição no campo da saúde no novo cenário político do que o movimento indígena. Caberá a estudos futuros investigar em que medida é razoável pensar que os encaixes e sua articulação como domínios de agência constituem peças-chave seja na preservação dos ganhos alcançados por esses movimentos graças aos longos processos de interação socioestatal ocorridos nas últimas décadas seja, ainda, na capacidade do SUS de responder de forma efetiva às demandas dessas populações por melhores condições de saúde. 


\section{RefERÊNCIAS}

ALVAREZ, Sonia. Engendering Democracy in Brazil: Women's Movements in Transition Politics. New Jersey: Princeton University Press, 1990.

ALVAREZ, Sonia. Para além da sociedade civil: reflexões sobre o campo político feminista. Cadernos Pagu, 2014, n. 43, pp. 13-56.

BAIRD, Marcelo F. As agências reguladoras no governo Dilma: trajetória errática? In: Congresso de Gestão Pública, 7., 2014, Brasília. Anais... Brasília: Consad, 2014.

BIROLI, Flávia e MIGUEL, Luis F. Women's political representation and gender issues in Brazil: advances, limits, and reactions. Manuscrito, 2016.

CÂMARA, Cristina; LIMA, Ronaldo. Histórico das ONG/Aids e sua contribuição no campo das lutas sociais. Cadernos Abong, 28 out. 2000, pp. 29-74.

CAMPOS, Luiz; MENDONÇA, Patricia; ALVES, Mario A. (2012), From 'dot. org' to 'dot.gov': Professional Crossings in the Brazilian National Policy on HIV/ AIDS. Voluntas, v. 36. n. 1, pp. 236-256.

CARDOSO, Marcos. O movimento negro. Belo Horizonte: Maza, 2002.

CARLOS, Euzeneia. Movimentos sociais e instituições participativas: efeitos do engajamento institucional nos padrões de ação coletiva. Revista Brasileira de Ciências Sociais, 2015a, v. 30, n. 88, pp. 83-99.

CARLOS, Euzeneia. Movimentos sociais e instituições participativas: efeitos do engajamento institucional no contexto pós-transição. Belo Horizonte: Fino Traço, 2015b.

CARVALHO, Layla P. Feminismos, movimentos de mulheres e as politicas de saude para as mulheres. [s.l: s.n.], 2017. (USP, relatório de pesquisa)

CASTILHO, Euclides; CHEQUER, Pedro. Epidemiologia do HIV/Aids no Brasil. In: Parker, Richard (Ed.). Políticas, Instituições e Aids: enfrentando a epidemia no Brasil. Rio de Janeiro: Jorge Zahar/ABIA, 1997.

COELHO, Vera S. et al. Creating Systemic Change in Brazil: Solutions to Poverty Through Accountable and Representative Policy Processes. [s.l.]: [s.n.], 2014 a. (Relatório de pesquisa)

COELHO, Vera S. et al. The Access of the Indigenous and Black Movements to the Hiv/AIDS Policy Arena in Brazil: Effectiveness and Accountability to the Most Vulnerable. São Paulo: [s.n.], 2014b. (Cebrap, relatório de pesquisa) 
COLEBATCH, Hal K. Policy. Buckingham: Open University Press, 1998.

CORNWALL, Andrea; ROMANO, Jorge; SHANKLAND, Alex. Brazilian Experiences of Participation and Citizenship: A Critical Look. Brighton: IDS, 2009. (IDS Research Summary, n. 389)

DAMASCO, Mariana S. Feminismo negro: raça, identidade e saúde reprodutiva no Brasil, 1975-1996. Dissertação (Mestrado em História das Ciências e da Saúde) Fundação Oswaldo Cruz, Rio de Janeiro, 2009.

DOWBOR, Monika. A arte da institucionalização: estratégias de mobilização dos sanitaristas (1974-2006). Tese (Doutorado em Ciência Política) - Universidade de São Paulo, São Paulo, 2012. Disponível em: <http://dx.doi.org/10.11606/T.8.2012. tde-06032013-111003>.

ESCOREL, Sarah. Reviravolta na saúde: origem e articulação do Movimento Sanitário. Rio de Janeiro: Ed. Fiocruz, 1998.

FRY, Peter et al. Aids tem cor ou raça? Interpretação de dados e formulação de políticas de saúde no Brasil. Cadernos de Saúde Pública, 2007, v. 23. n. 3, pp. $497-$ 523.

GALVÃO, Jane. 1980-2001: uma cronologia da epidemia de HIV/AIDS no Brasile no mundo. Rio de Janeiro: ABIA, 2002.

GALVÃO, Jane. Brazil and Access to HIV/AIDS Drugs: A Question of Human Rights and Public Health. American Journal of Public Health, 2005, v. 95, n. 7, pp. 1110-1116.

GUIMARÃES, Antonio S. A questão racial na política brasileira (os últimos quinze anos). Tempo Social, 2001, v. 13. n. 2, pp. 121-142.

GUIMARÃES, Antonio S. Contexto histórico-ideológico do desenvolvimento das ações afirmativas no Brasil. In: Seminário Internacional "Ações afirmativas nas políticas educacionais brasileiras: o contexto pós-Durban”. Brasília: Ministério da Educação/Câmara Federal, 2005.

GUIMARÃES, Antonio S. Cidadania e retóricas negras de inclusão social. Lua Nova, 2012, n. 85, pp. 13-40.

GURZA LAVALLE, Adrian; HOUTZAGER, Peter; CASTELLO, Graziela. A construção política das sociedades civis. In: Gurza Lavalle, Adrian (Ed.). O horizonte da politica: questôes emergentes e agendas de pesquisa. São Paulo: EdUnesp/Cebrap/ CEM, 2012, pp. 185-259. 
HOUTZAGER, Peter; GURZA LAVALlE, Adrian. Civil Society's Claims to Political Representation in Brazil. Studies in Comparative International Development, 2010, v. 45, pp. 43-77.

LIMA, Márcia. Desigualdades raciais e políticas públicas. Novos Estudos Cebrap, 2010, n. 87, pp. 77-95.

MAIO, Marcos Chor; MONTEIRO, Simone. Tempos de racialização: o caso da 'saúde da população negra' no Brasil. História, Ciências, Saúde - Manguinhos, 2005, v. 12 , n. 2, pp. 419-446.

NUNN, Amy. The Politics and History of AIDS Treatment in Brazil. New York: Springer, 2009.

OPAS - Pan American Health Organization. Health of indigenous peoples. PanAm J Public Health;2(5):357-362, 1997.

PARKER, Richard. Construindo os alicerces para a resposta ao HIV/Aids no Brasil: o desenvolvimento de políticas sobre o HIV/Aids, 1982-1996. Divulgação em Saúde para Debate, n. 27, pp. 8-49, 2003.

RIBEIRO, Matilde. Mulheres negras: uma trajetória de criatividade, determinação e organização. Revista Estudos Feministas, 2008, v. 16. n. 3, pp. 987-1004.

RIOS, Flavia. O protesto negro no Brasil contemporâneo. Lua Nova, 2012, v. 85, pp. $41-79$.

RIOS, Flavia. Elite politica negra no Brasil: relação entre movimento social, partidos políticos e Estado. Tese (Doutorado em Sociologia) - Universidade de São Paulo, São Paulo, 2014.

RODRIGUES, Cristiano; PRADO, Marco A. Movimento de mulheres negras: trajetória política, práticas mobilizatórias e articulações com o Estado brasileiro. Psicologia e Sociedade, 2010, v. 22. n. 3, pp. 445-456.

ROSALEN, Juliana. Aproximações à temática das DST junto aos Wajãpi do Amapari. Tese de Doutorado. Universidade de São Paulo, 2005.

SAN SEBASTIÁN, Miguel; HURTIG, Anna-Karin. Review of Health Research on Indigenous Populations in Latin America, 1995-2004. Salud Pública de México, v. 49, n. 4, pp. 316-320, 2007.

SANTOS, Andreia B.; COELHO, Thereza C.B.; ARAUJO, Edna M. Identificação racial e a produção da informação em saúde. Interface, 2013, v. 17. n. 45, pp. 341356. 
SANTOS, Ivair Augusto A. O movimento negro e o Estado (1983-1987). São Paulo: CONE/Prefeitura de São Paulo, 2006.

TEIXEIRA, Paulo. Políticas públicas em Aids. In: Parker, Richard (Ed.). Políticas, instituições e Aids: enfrentando a epidemia no Brasil. Rio de Janeiro: Jorge Zahar/ ABIA, 1997.

TELLES, Edward. Racismo à brasileira. Rio de Janeiro: Relume-Dumará, 2003.

TILLY, Charles. Durable Inequality. Berkeley: University of California Press, 1999.

WILSON, Robert et al. Governance in the Americas: Decentralization, Democracy and Subnational Government in Brazil, Mexico and the USA. Notre Dame, IN: University of Notre Dame Press, 2008.

\section{DOCUMENTOS}

ALBERTI, Verena; PEREIRA, Amílcar. Histórias do movimento negro no Brasil: depoimentos ao CPDOC. Rio de Janeiro: Pallas, 2007.

APINA. Prioridades dos Wajäpi para 2007. Documento do Conselho das Aldeias Wajãpi - Apina. acapá Maio, 2007.

BENTO, Maria Aparecida S. A implementação do quesito cor na área da saúde: o caso da Prefeitura de São Paulo. In: Seminário de Saúde da População Negra, 1., 2004, Brasília. Anais... Brasília: MS/Seppir, 2004.

BRASIL. Ministério da Saúde. Secretaria de Políticas de Saúde. Coordenação Nacional de DST e Aids. Aids no Brasil: um esforço conjunto governo-sociedade. Brasília: MS, 1998.

CARNEIRO. Sueli; SANTOS, Tereza. Mulher negra. São Paulo: Conselho Estadual da Condição Feminina/Nobel, 1985.

FUNASA. Fundação Nacional de Saúde. Ministério da Saúde. Portaria n. 852, de 30 de setembro de 1999. Disponível em: <http://6ccr.pgr.mpf.gov.br/institucional/ grupos-de-trabalho/saude/docs_legislacao/portaria_852_1999.pdf >.

GELEDÉS. Geledés - Instituto da Mulher Negra. Declaração de Itapecerica da Serra das mulheres negras brasileiras. São Paulo: Geledés, 1993.

LOPES, Fernanda; WERNECK, Jurema. Participação e controle social para a equidade em saúde da população negra. Rio de Janeiro: Criola, 2007. 
MARCHA... Marcha Zumbi dos Palmares contra o racismo, pela cidadania e a vida. Brasília: Cultura Gráfica e Editora, 1996.

PESQUISADORES WAJĀPI. Imovyvya. [s.l.]: Comunidade Wajãpi, 2009. (Série Jane Reko Mokasia). Disponível em: http://www.apina.org.br/documentos/livro_ Jane_Reko_Mokasia.pdf. Acesso em: 30 jun. 2018.

ROLAND, Edna. O ovo e a galinha. Cadernos Geledés, 1991, caderno 1, pp. 17-19.

SEPPIR. Secretaria Especial de Políticas de Promoção da Igualdade Racial. BrasilAfroatitude: Programa Integrado de Ações Afirmativas para Universitários Negros. Brasília: Secretaria da Presidência, 2005.

SNPDRMN. Seminário Nacional Políticas e Direitos Reprodutivos das Mulheres Negras. Declaração de Itapecerica da Serra das mulheres negras brasileiras. São Paulo: Geledés - Instituto da Mulher Negra, 1993.

WERNECK, Jurema; MENDONÇA, Maisa; WHITE, Evelyn C. O livro da saúde das mulheres negras: nossos passos vêm de longe. Rio de Janeiro: Criola/Pallas, 2000.

WORLD BANK. Project Appraisal Document on a Proposed Loan for the Federative Republic of Brazil for the AIDS and STD Control Project III. Washington: The World Bank, 2003.

\section{Lista de entrevistadas e entrevistados citados}

MARMO, José. José Marmo, pioneiro na prevenção à Aids para a população afrobrasileira e coordenador nacional da Rede Nacional de Religiões Afro-Brasileiras e Saúde (1 mar. 2010). Entrevistadora: Eliane Barbosa.

PELLEGRINI, Marcos. Marcos Pellegrini, ex-coordenador do Programa de HIV/ Aids para populações indígenas do Ministério da Saúde (jun. 2009). Entrevistadora: Vera Schattan Coelho.

ROLAND, Edna. Edna Roland, ativista no combate ao racismo, especialista da ONU e diretora do Geledés. (22 fev. 2010). Entrevistadoras: Eliane Barbosa e Silvia Aguião. 



\section{Capítulo 8 \\ IDEIAS E INTERAÇÕES: A GENERIFICAÇÃO DE DUAS POLÍticas PÚBliCAS NO PARAGUAI}

José Szwako

Renato Perissinotto

\section{Introdução}

A literatura internacional sobre ação coletiva, em ambas vertentes hoje clássicas, desvencilhou as formas não convencionais de mobilização dos liames das macroestruturas e de suas supostas crises, faltas e patologias. Enquanto alguns enfatizaram o confronto vis-à-vis sistema político, a outra vertente sublinhou características e dimensões expressivas da ação dos novos movimentos sociais que "implica[m] relações sociais, símbolos, identidades e necessidades individuais" (Melucci, 2003, p. 99; tradução nossa). ${ }^{1}$ Embora a principal contribuição desse teórico italiano tenha sido sua proposta de decomposição analítica interna à noção de 'identidade', sua ambição teórica mais ampla consistiu fundamentalmente em afirmar que a luta dos movimentos sociais se inscreve, aquém e além do sistema político, nos "sistemas simbólicos e no domínio sócio-cultural" (idem).

Como foi visto na introdução deste livro, a literatura brasileira recente sobre movimentos sociais foi pródiga em fazer avançar e também criticar os pressupostos da contentious politics:

1 Todas as traduções de citação bibliográfica e empírica são nossas. 
as interações dos movimentos sociais e das organizações da sociedade civil não são necessariamente, nem apenas ou sobretudo, conflituosas com atores burocráticos e partidários ou arranjos político-institucionais. Quer dizer, formas não conflituosas de interação conformam também o leque pelo qual Estado e atores não estatais se aproximam não somente produzindo efeitos político-institucionais (i.e., políticas públicas), mas também, e é o que queremos enfatizar aqui, negociando e disputando seus sentidos. Retomando e revirando Melucci (2003), podemos dizer que há sempre uma dimensão expressiva (simbólica, projetiva, ideacional) que atravessa as interações socioestatais, os efeitos delas advindos e eventualmente institucionalizados em políticas públicas.

Para escrutinar essa dimensão expressiva implicada nas dinâmicas de incorporação e institucionalização de demandas dos movimentos sociais, vamos dar três passos. $\mathrm{O}$ primeiro deles consiste em sugerir que o debate sobre ideias e políticas públicas, conhecido como virada ideacional (Cf. Blyth, 1997), pode ser analiticamente fértil para entender o componente simbólico-expressivo dos efeitos das interações entre Estado e movimentos sociais. O segundo passo é, seguindo V. Schmidt (2010), levar ideias e discursos a sério na análise de duas políticas públicas desenvolvidas a partir da interação entre organizações feministas e partes do Estado paraguaio. Em ambos os casos, trata-se de entender em que medida e por meio de quais arenas de interação a categoria 'gênero', forjada pelo discurso militante feminista, interpelou as políticas tanto de combate à violência contra a mulher como de saúde sexual e reprodutiva naquele país. Nas conclusões, atentos aos desdobramentos e discursos ao redor dessas políticas permeadas por 'gênero', contra ou favor delas, sugerimos a noção de capacidade cognitiva como heuristicamente útil para apreender as disputas de sentido ao redor do Estado e das políticas públicas. 


\section{A virada ideacional}

A literatura da "virada ideacional" avançou na discussão sobre o impacto das ideias em políticas públicas de três maneiras. ${ }^{2} \mathrm{~A}$ primeira delas refere-se à apresentação de garantias de que ideias possam de fato se consideradas como variáveis explicativas de direito próprio, algo que é inseparável da identificação de procedimentos metodológicos e comprobatórios específicos. A segunda dimensão refere-se à produção de uma definição mais precisa e refinada do que sejam ideias e dos seus impactos. Por fim, outro avanço reside na explicitação das condições de viabilidade das ideias, isto é, na identificação das circunstâncias que lhes permitem produzir efeitos sobre os outcomes políticos.

No que diz respeito ao primeiro ponto, os autores que pensaram as ideias como variáveis explicativas fizeram um esforço muito grande no sentido de explicitarem o seu papel causal nos fenômenos analisados. $\mathrm{O}$ ponto de partida visa a estabelecer os princípios básicos de uma "teoria ideacional” como teoria causal, que deve afirmar que uma dada estrutura cognitiva influencia o comportamento de um ator numa situação de escolha, sendo que essa estrutura cognitiva deve ser autônoma em relação às condições materiais e objetivas que caracterizam o contexto analisado (Jacobs, 2015). Ainda segundo Jacobs, “O traço distintivo de uma teoria ideacional é que [os] objetivos e crenças [dos atores sociais e políticos] podem variar independentemente das condições objetivas materiais, gerando diferentes decisões" (Jacobs, 2015, p. 7). Se uma teoria ideacional não conseguir fazer isso, então, na verdade, estamos na presença de uma “explicação materialista”. Portanto, qualquer teoria ideacional deve mostrar três tipos de evidências:

2 Este subitem retoma parcialmente nossa análise exposta em Perissinotto e Szwako (2017). 
primeiro, que os decisores possuem crenças particulares; segundo, que as crenças modelam suas escolhas; e, por fim, que suas crenças não são redutíveis às condições materiais da situação de escolha. A melhor maneira de se fazer isso é juntar diacronia com comparação. Como diz Sheri Berman, é preciso mostrar que um mesmo ator fará escolhas similares ao longo do tempo, mesmo quando enfrenta mudanças contextuais, e comprovar que atores diferentes tomam decisões distintas frente a condições similares (Berman, 1998, pp. 33-34).

No entanto, a operacionalização adequada dessa teoria e desses procedimentos exige uma clara definição do que se entende por ideias, condição necessária, por sua vez, para uma adequada descrição da configuração ideacional que se pretende analisar. Do que se fala, afinal de contas, quando temos em mente as ideias de um grupo social, de um conjunto de atores políticos ou de líderes de uma dada organização? Das suas visões de mundo mais amplas? Dos seus valores e pré-noções mais profundos? Das suas crenças referentes a problemas específicos e suas resoluções? Quando se trata de discutir esse ponto, os autores da virada ideacional procuram diferenciar as ideias pela sua abrangência e capacidade estruturante, como sintetiza o Quadro a seguir elaborado por Campbell (1998).

\section{Quadro 1: Dimensões e constrangimentos dos discursos}

\begin{tabular}{|c|l|l|}
\hline \multicolumn{3}{|c|}{ Dimensões } \\
\hline \multirow{2}{*}{ Constrangimentos } & $\begin{array}{l}\text { Conceitos de primeiro plano } \\
\text { (foreground concepts) }\end{array}$ & $\begin{array}{l}\text { Pressupostos de fundo } \\
\text { (background assumptions) }\end{array}$ \\
\hline Nível cognitivo & Programas & Paradigmas \\
\hline Nível normativo & Enquadramento & Sentimentos públicos \\
\hline
\end{tabular}

Fonte: Campbell, 1998. 
O background descreve os pressupostos infraconscientes que habitam o pano de fundo dos debates políticos, delimitando-os; o foreground descreve as ideias usadas e articuladas estrategicamente pelos atores envolvidos direta e indiretamente nas lutas políticas. Constrangimentos podem ser normativos, isto é, quando ideias se constituem em valores e atitudes que diferenciam o certo do errado, legitimando determinadas formas de pensar e estigmatizando outras; constrangimentos também podem ser de natureza cognitiva, isto é, quando conceitos culturalmente dados são operacionalizados para autorizar determinadas soluções de problemas específicos e para desautorizar outras.

Assim, de acordo com o Quadro, paradigmas e programas são constrangimentos cognitivos que definem, em dimensões distintas, maneiras socialmente aceitas de resolver problemas. No caso de paradigmas, pressupostos de fundo, internalizados pelos agentes em processos de socialização de longa duração, limitam o elenco de soluções que as elites políticas ou de uma organização qualquer tendem a perceber como adequadas; no caso dos programas, trata-se de prescrições precisas de políticas públicas mobilizadas estrategicamente na luta política e que, autorizadas por paradigmas, facilitam a ação entre tomadores de decisão para definir como resolver um problema específico de política pública (Campbell, 1998). Os sentimentos públicos e o enquadramento são, por sua vez, constrangimentos normativos que impõem distinções entre o certo e o errado, e que também operam em dimensões distintas. Sentimentos públicos são pressupostos normativos de fundo, internalizados, que legitimam ou deslegitimam, que autorizam ou desautorizam, enfim, que tornam determinados temas aceitáveis ou inaceitáveis ao público. Fornecem, assim, uma base extrainstitucional ou, se se quiser, cultural da legitimidade política. Enquadramento refere-se a um modo de, na luta política, apresentar estrategicamente certos programas e soluções com vistas a torná-los compatíveis com o sentimento público dominante e, 
assim, legitimá-los perante a população. A luta política deve ser entendida, portanto, como um embate permanente de enquadramento e contraenquadramento (Campbell, 1998; Hay, 1996). É claro que esses constrangimentos e dimensões estão interligados. Como diz Campbell, "paradigmas e sentimentos públicos são conceitos de segunda ordem na medida em que se constituem em ideias subjacentes sobre as quais os conceitos de primeira ordem, isto é, programas e enquadramentos, baseiam-se respectivamente" (1998, p. 385).

O avanço advindo dessa literatura aponta para a identificação das circunstâncias que, uma vez presentes, aumentam a potencialidade de impacto nas decisões políticas. Esse ponto é importante, pois os autores da virada ideacional não defendem qualquer sorte de idealismo. Afirmam, antes, que ideias não operam sozinhas e que a presença de certas condições políticas e institucionais são fundamentais para que possam produzir efeitos institucionais. Em geral, identificam-se três condições de viabilidade. A primeira delas refere-se a condições propriamente ideacionais, isto é, uma ideia será tanto mais poderosa, quanto mais vinculada a uma tradição ideacional prévia que cria uma path dependence ideacional. A segunda condição de viabilidade diz respeito à recepção da ideia em questão por instituições com capacidade decisória, isto é, de formular seus objetivos influenciadas por essas ideias e de possuir recursos institucionais que sustentem a implementação de suas decisões. Por fim, toda ideia, para ser efetivamente operacionalizada, precisa ancorar-se numa coalizão política, precisa encontrar pessoas dispostas a sustentá-la (carriers, cf. Berman, 1998), precisa dos seus political entreprenuers (Kingdon, 2014), agentes dispostos a defender tais ideias e inseridos numa coalizão que dê sustentação a suas atividades. Com relação a este último ponto, é importante observar a reciprocidade entre ideias e coalizões, pois se estas são condições de viabilidade política das ideias, aquelas, 
por sua vez, também aumentam as chances de uma coalizão se formar (Gourevitch, 1986).

O debate sobre impacto das ideias em políticas públicas sintetiza-se, então, em três pontos: epistemológico/metodológico, conceitual e contextual. Esse debate interessa especialmente à agenda da institucionalização de demandas de movimentos sociais porque sua ênfase numa ideia, elaborada e eventualmente institucionalizada, reúne duas faces da ação dos movimentos sociais: cognitiva e simbólica, ideacional e cultural. Ao mesmo tempo em que as demandas formuladas por movimentos sociais sintetizam suas ideias a respeito de como deve se orientar tal ou qual política pública, elas carregam uma forte carga expressiva daquilo que organizações e militantes projetam como ideal, não só de Estado, mas de sociedade mais amplamente. Para iluminar tanto as interações socioestatais ao redor da noção de 'gênero' pelas lentes da virada ideacional, utilizamos em especial as categorias analíticas de sentimentos públicos e enquadramento/contraenquadramento, sugerindo as noções de trajetória intelectual e de capacidade cognitiva como complemento a tais categorias. Vejamos, então, como a ideia de 'gênero' foi forjada pelas experiências e saberes dos feminismos no caso paraguaio. Reconstruiremos, a seguir, momentos-chave nos quais o 'gênero' esteve no centro das demandas feministas vis-á-vis Estado paraguaio. Mais adiante, observamos como essa demanda interpelou duas políticas públicas no país, causando um duplo efeito: um primeiro almejado pelas atrizes do movimento feminista (qual seja, institucionalizar parcialmente o 'gênero' em políticas) e outro efeito inesperado, que foi a produção de pânicos morais (anti-'gênero') e a mobilização de militantes do contramovimento religioso em oposição (moral e cultural) àquela mesma institucionalização. 


\section{3. 'Gênero' - ideia, identidade e demanda}

As dinâmicas de interação socioestatal por meio das quais partes do Executivo paraguaio foram permeadas pela "perspectiva de gênero" transcorreram no contexto de transição e democratização do Paraguai que marcou a década de 1990 no país, após a deposição do general Alfredo Stroessner em 1989. Grosso modo, esse processo de generificação (Szwako, 2012), ou gender mainstreaming, ${ }^{3}$ passou por três momentos-chave na incorporação e difusão do "enfoque de gênero" pelo Estado paraguaio. O primeiro deles é a gênese da Secretaria da Mulher, órgão com estatuto ministerial, criada em 1993 em boa medida como uma forma de articulação entre a então recém-empossada ministra com uma fração do feminismo paraguaio distinguida por sua verve partidária, a então Multisectorial de Mujeres. O segundo momento importante na generificação estatal paraguaia se deu ao redor da IV Conferência Mundial da Mulher ocorrida em Beijing, em 1995, que serviu como uma oportunidade internacional para as demandas de organizações e ativistas da mais antiga articuladora civil feminista do país, a Coordenação de Mulheres do Paraguai (CMP). Já o terceiro momento abarca o período posterior ao mês de março de 1999 , quando eclodiu o chamado Marzo paraguayo - violento ciclo de protestos disparado pelo assassinato do então vice-presidente do Paraguai e cujo confronto entre manifestantes e forças repressivas levou à morte de oito dos primeiros. De 1999 em diante, uma

3 Tomamos aqui generificação e gender mainstreaming como sinônimos. Entendemos generificação como a estruturação de instrumentos, iniciativas e agências estatais a partir da ideia de gênero. Seria a primeira parte (o componente prático) na definição de S. Walby, segundo a qual gender mainstreaming "is both a new form of gendered political and policy practice and it is a new gendered strategy for theory development. As a practice, gender mainstreaming is intended as a way of improving the effectivity of mainline policies by making visible the gendered nature of assumptions, processes and outcomes" (Walby, 2005, p. 321). No português, a expressão pode ser tomada também como "transversalização de gênero". 
vez normalizado o pacto político no seio das elites e partidos paraguaios, ${ }^{4}$ a incorporação da "categoria de gênero" deu vez à sua institucionalização com essa ideia passando a permear e a estruturar diversas partes e agências do Estado paraguaio, por certo, não restritas ao Poder Executivo. 5

Vale notar que a IV Conferência Mundial da Mulher é, não à toa, central nos rumos da generificação estatal no Paraguai, pois essa reunião esteve inserida na "década das conferências" (Lindgren-Alves, 2001). Quer dizer, antes e depois de 1995, outras conferências mundiais serviram como palcos internacionais nos quais foram debatidos e priorizados temas moral e politicamente sensíveis ou emergentes, a exemplo das questões ambientais e antirracismo, respectivamente na Rio 92 e em Durban, no ano de 2001. Nessa sequência de conferências destaca-se a Conferência Mundial de População e Desenvolvimento, no Cairo, que precedeu Beijing 1995 cronológica e tematicamente ao ter discutido a delicada questão dos direitos sexuais e reprodutivos. Dois traços nessas conferências atravessam e acompanham a luta feminista. O primeiro é o papel ativo e positivo desempenhado por agências e personagens do sistema internacional nas respectivas arenas e agendas nacionais. Neste sentido, Beijing 1995 foi um divisor de águas nas dinâmicas e estratégias de generificação por todo o mundo, ${ }^{6}$ implicando, "sem dúvida, um imenso impacto na

4 Os termos e, sobretudo, os limites desse pacto político ficaram evidentes com o golpe que tirou Fernando Lugo da Presidência em 2012. Sobre isso ver Szwako (2014).

5 Exemplo adequado disso no âmbito legislativo pode ser visto na Comisión Asesora Permanente de Equidad y Género do Senado paraguaio, cujo objetivo autodeclarado é "emitir dictámenes sobre proyecto de ley, resolución o declaración, vinculados al estudio o inclusión de criterios de equidad e igualdad de oportunidades, referidos a: deuda social, discriminación y segregación; especialmente, relacionadas con mujeres, minorías y grupos vulnerables". Ver: www.senado.gov.py.

6 Para o caso da União Europeia, ver "European Union Gender Policy Since Beijing: Shifting Concepts and Agendas" (Lombardo e Meier, 2007). 
política do movimento feminista e nas políticas de gênero por toda a América Latina e Caribe" (Alvarez et al., 2003, p. 554). O segundo aspecto aqui relevante é a quantidade de energia e recursos mobilizada, tanto no âmbito internacional como doméstico, pela oposição religiosa (católica ou outra) aos debates a respeito dos direitos humanos das mulheres. Exemplos desse investimento antifeminista foram a pressão do papa João Paulo II que "put pressure on Latin American governments to send anti-abortion delegates to the Cairo conference" (Franco, 2 abr. 1996, s.p.), bem como os assassinatos de mulheres que não usavam véu perpetrados, em 1995, pelo Front Islamique do Sud na Argélia, como resposta ao Dia Internacional da Mulher (Lindgren-Alves, 2001, pp. 214 e s.). Como veremos no caso paraguaio, estes dois fatores, quais sejam, a aliança com discursos e agências do sistema internacional e a oposição religiosa aos feminismos, são parte constante das narrativas, alianças, trajetórias e adversidades pelas e contra as quais se deram, e ainda se dão, as interações e estratégias rumo à cristalização da “concepção de gênero" em políticas públicas.

Se Beijing 1995 foi um catalisador das energias feministas e contra elas, isso não significa que essa conferência tenha inaugurado a elaboração de um ideário ao redor da categoria 'gênero' por parte das militantes e organizações feministas paraguaias. Já em 1989, após a queda do general Stroessner, as ativistas da Multisectotial de Mujeres contestavam um projeto elaborado pela tecnocracia herdada do regime stronista que se propunha, dentre outras coisas, a "promoção de mulher". ${ }^{7}$ Contra a proposta da STP de uma 'subsecretaria', a Multisectorial sugeria uma "secretaria com nível ministerial" que teria, entre seus objetivos, "conhecer de forma mais profunda a condição social das mulheres do nosso país, levando em conta a heterogeneidade de situações

7 Cf. "Plan Nacional de Desarrollo Económico y Social” (STP [Secretaría Técnica de Planificación], 1989-1990). 
e as formas de discriminação por razão de gênero" (MMP, 1989, p. 7). Dois anos mais tarde, ao mesmo tempo em que disputavam outras arenas institucionais, ${ }^{8}$ as demandas feministas por uma secretaria de nível ministerial encontraram eco na Comissão de Assuntos Constitucionais da Câmara de Deputados. De um esforço conjunto entre a Coordenação de Mulheres do Paraguai e a Multisectorial, foi redigido Bases para el proyecto de ley para la Secretaría de la Mujer, doravante Bases. A ponte junto à Comissão foi facilitada por Cristina Muñoz, deputada suplente do Partido Colorado e também militante da Multisectorial, que se tornou a primeira ministra da Secretaria da Mulher, criada por lei em 1992. Porém, à diferença daquele documento de 1989, este último projeto fala não tanto em 'gênero', mas sim em 'mulher' e 'mulheres'. $\mathrm{O}$ registro discursivo de Bases enquadra a necessidade de uma secretaria ministerial em um dos sentimentos públicos, retomando Campbell, mais incontestes da história e da cultura paraguaias: a grande guerra e a nostalgia de um suposto passado heróico e grandioso (Cf. Rodríguez-Alcalá, 2005). ${ }^{10}$ Lê-se em Bases:

8 Entre 1989 e 1993 (isto é, entre o fim da ditadura stronista e a primeira eleição presidencial paraguaia) se deu o reordenamento dos eixos jurídico-normativos fundamentais do contrato político e social no país, tendo sido redesenhados ou realizados: o Código Eleitoral (1990), a Assembleia Constituinte (1991), eleições municipais (1991), a promulgação da Constituição (1992), o Código Civil (1992) e a eleição presidencial (1993). Nada desprezíveis, as conquistas feministas variaram em todas essas arenas; ver Szwako (2012, pp. 135-205).

9 Veja-se: "é evidente a discriminação contra as mulheres"; "a situação das mulheres na nossa sociedade poderia ser sintetizada como de muito trabalho e pouco poder"; "o Estado paraguaio está em dívida com as mulheres"; "questão da mulher"; "[nada] pode justificar a ausência de políticas públicas adequadas para possibilitar a plena participação das mulheres no Paraguai"; e, ainda, uma secretaria ministerial seria "[a] máxima instância de coordenação e de decisão de políticas orientadas à mulher” (MMP, CMP, 1991, pp. 70, 71, 73).

10 Importante notar que a produção ideológica do regime stronista se ancorou e fomentou esse sentimento público anexando a figura do general Stroessner ao panteão dos heróis do nacionalismo paraguaio. As análises do discurso nacionalista são claras nas implicações políticas da produção de figuras que fazem as vezes de párias da nação. "De acordo com isso [com a ideologia nacional], o Marechal Lopez é o chefe que, cega e voluntariamente, deve ser obedecido [...]. 
Nem $10 \%$ da população que sobreviveu a Guerra contra a Tríplice Aliança para semear, comerciar, transformar produtos, cuidar do gado, cozinhar, criar filhos, ensinar e governar, eram homens. A reconstrução nacional foi obra das mulheres, mas apenas quanto ao trabalho. Não foram elas que tinham o poder de decisão na sociedade, nem no Estado. $\mathrm{Na}$ realidade, praticamente não tinham direitos. Quem teve sob sua responsabilidade a produção durante a Guerra do Chaco? Quem manteve durante toda a história a maioria dos lares paraguaios? Todos sabemos a resposta (MMP, CMP, 1991, p. 70).

A evocação do imaginário bélico não é menor nesse argumento feminista, pois é com esta passagem que se abre Bases. $\mathrm{O}$ que ele faz é um trabalho de enquadramento interpretativo adequado ao ideário da audiência daquela Comissão composta por stronistas e uns poucos não stronistas, ambos, defensores do imaginário nacionalista e idealizado do passado paraguaio. Esse registro discursivo foi estratégico, uma ideia eficazmente exposta com um fim preciso: a criação da Secretaria da Mulher.

Outra pista de como a ideia de 'gênero' conformou o intelecto das feministas no Paraguai pode ser vista em Hacia una presencia diferente. Mujeres, organización y feminismo (Echauri et al., 1992). Neste livro, as feministas pesquisadoras do Centro de Documentación y Estudios ${ }^{11}$ produzem uma espécie de memória "da luta das mulheres" no país; para tanto, elas dizem, "es

O 'doutor' Francia é o criador, o único criador da nacionalidade paraguaia. Em todos os casos, estes indivíduos 'são' a pátria; criticar sua atuação política é ser 'antiparaguaio"” (Rodríguez-Alcalá, 2005, p. 127). E mais: “estar contra os símbolos da nação - o guarani, o Marechal Lopez e outros símbolos [...] - é estar contra ela (já que exprimem a sua [suposta e imposta] essência) e contra o Estado (governo) que a interpreta e, portanto, é ser anti-paraguaio" (Zuccolillo, 2000, p. 221; destaques no original).

11 Centro de Documentación y Estudios (CDE) é renomada ONG fundadora da CMP e com ampla atuação na sociedade civil paraguaia. 
preciso analizar tanto la práctica de mujeres organizadas como la de individualidades [...] que mucho han hecho por el avance de la conciencia de género en nuestro país" (1992, p. 3). Nesse resgate, sua divisão metodológica classifica aqueles grupos ou organizações de mulheres que "se caracterizan por la incorporación de elementos de género a su práctica" e aquelas que, "sin negar la existencia de la discriminación femenina, [en] su práctica no incorpora[n] elementos de género" (1992, p. 12). Como o ideário feminista não coincide com a totalidade das organizações de mulheres, elas distinguem o feminismo não só como movimento, mas também como postura. "Por una parte, el término feminismo designa una determinada postura frente a la situación de la mujer en la sociedad y por otra se refiere a un movimiento social basado en reivindicaciones de género" (1992, p. 61). Feminismo e 'gênero' são aí associados. "El feminismo puede ser definido en base a tres características: (a) reconocimiento de la discriminación social de la mujer; (b) identificación de la base cultural e ideológica, no natural, de esta discriminación; (c) elaboración de propuestas y acciones concretas para transformar la situación de discriminación" (1992, p. 61). Enquanto a última parte dessa citação nos fala de gender mainstreaming, a segunda parte nos remete ao núcleo distintivo do conteúdo da ideia de gênero, isto é, ao caráter não biológico das diferenças e desigualdades entre homens e mulheres. Embora tal ideia pareça bastante simples, uma vez tendo conquistado espaço normativo, ela causou, desde Beijing, fortes reações e pânicos.

Antes de passarmos à análise de duas políticas permeadas por 'gênero', vejamos como a noção de 'gênero' pautou as interações e alianças feministas no contexto da IV Conferência Mundial da Mulher. Como produto de uma série de encontros e debates transcorrida um ano antes de Beijing 1995 com uma variedade de mulheres mobilizadas (trabalhadoras urbanas e campesinas, ligadas a partidos ou ONGs), as feministas da Coordenação de Mulheres do Paraguai redigiram Mujeres paraguayas camino a 
Beijing/Kuña Paraguay Beijing Rapere: documento no gubernamental del Paraguay para el Foro Internacional sobre la Mujer de Beijing 95 (CMP, 1994). No caminho rumo a Beijing, a evocação à ideia de 'gênero' operou duplamente. Por um lado, a "consciência de gênero" teve ali função identitária. "[Nós] mulheres com consciência de gênero queremos construir modelos de desenvolvimento diferentes que permitam uma mudança na nossa condição sociocultural e, em consequência, na estrutura mesma da sociedade" (CMP, 1994, p. 110). Por outro, a "perspectiva de gênero" encerra a própria demanda delas - das feministas com tal "consciência"12 - para o Estado paraguaio. "Se [nós] mulheres combinarmos o acesso ao poder com uma perspectiva de gênero, teremos capacidade para construir um modelo de sociedade diferente sem as discriminações que hoje existem por diferentes motivos" (idem, p. 115). Os exemplos dessa dupla função desempenhada pelo 'gênero' como identidade e como reivindicação de sua incorporação em políticas públicas se multiplicam pelo documento (idem, pp. 102, 104, 118 e 119) e podem ser assim resumidos: "[nós com consciência de gênero] recomendamos que o governo tenha uma política clara de desenvolvimento no econômico e social com uma perspectiva de gênero" (idem, p. 122).

$\mathrm{Na}$ trajetória intelectual do 'gênero' e na generificação das políticas públicas paraguaias, Beijing 1995 foi uma oportunidade para selar a aliança entre Cristina Muñoz (então à frente da Secretaria da Mulher) e as lideranças da Coordenação de Mulheres do Paraguai, duas das quais foram convidadas para compor a de-

12 Ao que parece, o termo na primeira metade dos anos 1990 não era consensual fora dos limites das organizações feministas. "Ainda não se compreende bem o alcance do significado do feminismo e da consciência de gênero [...]. Não apenas precisamos compreender o significado desses termos, mas também exercitar e capacitar a mulheres e homens para que atuem desde uma perspectiva de gênero, [capacitar] principalmente a profissionais da saúde, juízes e juízas, policiais e, em geral, a todos e a todas, tanto no setor público quanto no privado" (CMP, 1994, p. 87). 
legação oficial do país no encontro da ONU. Contudo, ainda que tenha rendido efeitos institucionais generificados no pós-Beijing, ${ }^{13}$ essa aliança teve de encarar o catolicismo conservador paraguaio e dividir espaço com ele no âmbito mesmo da delegação. Em sua ida à China, o Paraguai se antecipava emitindo nota de sua expectativa de "acordos para o fomento de Programas de Planificação Familiar com a condição básica do respeito à vida, isto é, que se aceitam os métodos que não interrompam o nascimento da vida”. Já na volta da China, o Estado paraguaio colocou reservas ao acordo da Conferência selado na "Declaración e Plataforma de Acción de Beijing”, expressamente anti-'gênero':

Respecto al término 'género' utilizado en los documentos adoptados en el seno de esta Conferencia, el Gobierno del Paraguay interpreta que dicho concepto se refiere a ambos sexos: el hombre y la mujer, y con dicho alcance ha sido incorporado en sus documentos nacionales (ONU, 1995, p. 180).

Pretensamente de volta à biologia, a "ambos os sexos", essas restrições dizem respeito fundamentalmente ao corpo feminino - sua capacidade reprodutiva, seu prazer sexual e sua proteção. Vamos, então, aos exemplos de como e em que medida a ideia de 'gênero' permeou a duas normativas estatais no Paraguai.

13 Veja-se o primeiro instrumento abrangente da Secretaria da Mulher, o Plan Nacional de Igualdad de Oportunidades para las Mujeres, 1997-2001, que foi "resultado de uma ampla consulta aos setores público e privado implicados. Este processo se legitima como instrumento orientador das políticas públicas setoriais de gênero" (Paraguay, 1997b, p. 126; destaque nosso). 


\section{Ideias e interações: a generificação das políticas de combate à violência contra a mulher e de direitos sexuais e reprodutivos no Paraguai}

O Plan Nacional de Salud Reproductiva traz em seu nome a marca e o peso das conferências internacionais, com seu subtítulo “versão pós-Cairo”. ${ }^{14}$ Datado de 1997, incorpora 'gênero' entre seus 'eixos' e 'mudanças fundamentais'.

Más allá de los aspectos de población, mortalidad, fecundidad (visión [desde la] demografía); [el Plan] incorpora la consideración de 'calidad de vida' con énfasis en la satisfacción de las necesidades de hombres y mujeres como individuos, desde el derecho de las personas, la equidad social y de género (Paraguay, p.1997a, s.p.).

$\mathrm{Na}$ raiz deste caso de generificação estatal se nota a presença de Kuña Aty, ${ }^{15}$ organização feminista que então compunha a CMP. Ao lado dela, na "elaboração e revisão" do Plan, estão outras organizações civis, agências do sistema internacional e de ajuda internacional, bem como organismos governamentais. Visto na trajetória das ações institucionais já existentes, este Plan reformula e se sobrepõe a programas anteriores, pois se 'actualizan los conceptos para la fundamentación teórica del Plan’. É então por via cognitiva que se incorpora a 'perspectiva de gênero'. Segundo o Plan,

${ }^{14}$ Cf. "Se denomina así al presente Plan, pues se caracteriza por considerar como eje, los cambios sustanciales que se han dado en la Conferencia Internacional sobre Población y Desarrollo del Cairo (1994) y la Plataforma de Acción de Beijing (1995)" (Paraguay, 1997a).

15 Tendo atuado por mais de duas décadas, a Fundação Kuña Aty (reunião ou lar de mulheres, em guarani) foi a ONG liderada pela feminista histórica Gloria Rubin, que foi ministra da Mulher entre 2008 e 2013. A ONG foi referência no país na proteção e atendimento de mulheres vítimas de violência seja física, sexual ou outra. 
[la] perspectiva de género nos permite identificar los roles asignados socialmente a hombres y mujeres que imponen estereotipos y dificultan el desarrollo pleno del potencial de los individuos. En este sentido el enfoque de género permite la identificación de características socialmente construidas que definen y ponen límites al quehacer femenino y masculino a partir de la construcción de símbolos, imágenes y representaciones, normas, patrones institucionales y elementos subjetivos de identidad, que distinguen a los sexos y con ello pretenden justificar relaciones diferenciadas sobre el aprovechamiento y uso de los recursos sociales (Paraguay, 1997a, p. 15).

Produto da interação com atrizes e organizações, tanto civis como internacionais, essa definição de 'gênero' - de tom feminista, diga-se - convive textualmente com tensões, oposições e heranças que remetem a Cairo e Beijing:

Las discusiones generadas en torno a los conceptos de Derechos Sexuales y Reproductivos resultan hasta ahora temas polémicos y de alta complejidad. Sin embargo la comunidad internacional ha reconocido y propiciado la realización de numerosos eventos para realizar la importancia de su abordaje y tratamiento (Paraguay, 1997a, p. 12).

Datado de 2003, o segundo Plan coloca 'gênero' no seu objetivo estratégico, que visa "[mejorar] la salud sexual y reproductiva de la población del Paraguay a través de políticas [...] que aseguren la atención integral al individuo y a la comunidad con enfoque de derechos, calidad, género y equidad" (Paraguay, 2003, s.p.). Ao mesmo tempo, porém, em que se observa essa continuidade normativa, a falta de capacidade de enforcement do Plan deixava 
insatisfeitas as organizações feministas, de direitos humanos e de direito à saúde, que reivindicavam que:

[el] Estado debería incluir entre sus prioridades el cumplimiento de los planes, políticas y programas de salud que ya han incorporado el concepto de derechos sexuales y derechos reproductivos, de manera a garantizar [...] en especial a las mujeres, los niños y las niñas el acceso a los servicios básicos a la salud, de manera a disminuir las altas tasas de mortalidad materna e infantil (Codehupy, 2003, pp. 464-465). ${ }^{16}$

Reivindicação análoga a essa ressoa em um mecanismo internacional aberto à crítica das militantes feministas; para elas, "el acceso a servicios de atención a la salud de la mujer, y en particular de la salud sexual y reproductiva, constituye la esfera de mayor inequidad y un signo de clara exclusión de las mujeres" (Cladem Paraguay, CMP, CDE, 2005, p. 33). ${ }^{17}$

16 Pesquisa científica levada a cabo entre 1998 e 2002 também mostrou a limitação da política de saúde sexual e reprodutiva no Paraguai, em especial, de seus burocratas de rua - "providers of oral contraceptives and [intrauterine devices] IUDs [that] clearly impose unnecessary barriers to method use and continuation" (Chin-Quee, 2004, p. 146).

17 Conhecida por sua sigla CEDAW, a Convenção das Nações Unidas para a Eliminação de Todas as Formas de Discriminação contra a Mulher é um instrumento que compele, por meio de seu Comitê, sem força vinculante porém ao modo de sugestão e crítica, os Estados-parte a prestarem conta de seus esforços e iniciativas no fortalecimento dos direitos humanos das mulheres. Além disso, nas sessões de prestação de contas, há também espaço para a vocalização das demandas da sociedade civil. No caso em tela, a militância feminista atuou a partir da liderança e a articulação entre ClademParaguay, CMP e CDE, que redigiram o Informe Sombra CEDAW: vigilancia ciudadana sobre los derechos humanos de las mujeres en Paraguay (Cladem PY; CMP; CDE, 2005). Nas observações finais do Comitể CEDAW ao Estado paraguaio é possível ouvir o eco daquela reivindicação. "El Comité instó al Gobierno a que fortaleciera la ejecución de programas y políticas encaminados a brindar un acceso efectivo a las mujeres a la información sobre la atención y los servicios de salud, en particular en materia de salud reproductiva y métodos anticonceptivos asequibles, con la mira de prevenir 
Para sermos exatos, essas críticas não diziam somente respeito à saúde sexual e reprodutiva, mas à notória limitada capacidade instalada de vários órgãos do Executivo paraguaio. Exemplo de tal limitação podia ser visto em pleno século XXI, quando o nível de sub-registro de todo o sistema de saúde paraguaio, incluindo-se partes privada e pública, variava entre 70 e $75 \%$ (Cf. Martínez, E., 2001). Ou seja, a base de coleta e produção de dados a partir da qual o Ministério da Saúde podia fazer diagnósticos, projeções e prognósticos refletia, se muito, $35 \%$ da realidade populacional-hospitalar do país. Uma das iniciativas institucionais que tentou, com êxito, mudar esse limitado quadro foi o "Comitê DAIA". Entre 2003 e 2012, o DAIA (acrônimo de Disponibilidad Asegurada de Insumos Anticonceptivos) reuniu figuras-chave da burocracia estatal, de organizações civis e de agências do sistema e de ajuda internacional, entre elas a Organização Panamericana da Saúde e a USAID, sobretudo. ${ }^{18}$ Para o que aqui importa, o esforço conjunto desses atores liderados pelo USAID teve efeitos positivos para o Ministério da Saúde paraguaio que conquistou uma previsão orçamentária garantida por lei de compra de métodos contraceptivos e baixou o nível de desabastecimento desses mesmos métodos. A coalizão, não ao redor do 'gênero', mas do "planejamento familiar", ${ }^{19}$ frente ao legislativo e pela racionalização logística da política de saúde reprodutiva, fez do Paraguai "un modelo para los demás países que promueven la DAIA en la región" (Narváez, 2012, p. 1).

A remissão ao Comitê DAIA importa por duas razões além das mudanças institucionais com ele observadas. Atentos ao de-

abortos clandestinos" (Comité CEDAW apud Cladem PY; CMP; CDE, 2005, p. 218).

${ }^{18}$ Cf. Sistematización de la Experiencia del Comité DAIA Paraguay (Narváez, 2012).

19 Para uma das raízes intelectuais dessa visão dos direitos sexuais e reprodutivos centrada na ideia de "planejamento familiar", ver Planificacion familiar: un manual mundial para proveedores da Organização Mundial da Saúde (OMS, 2011). 
bate sobre a força das ideias, poderíamos sugerir provisoriamente uma diferenciação interna à noção de capacidade estatal: ${ }^{20} \mathrm{se}$, por um lado, a DAIA implicou um incremento na capacidade propriamente técnico-administrativa do Ministério, ou seja, nas suas formas de estruturação e distribuição de insumos para o planejamento familiar, a generificação estatal observada ao longo das versões do Plan pode ser entendida como uma mudança na capacidade cognitiva do Estado paraguaio - algo, afinal, reclamado pelas feministas desde antes de Beijing. Isso não significa certamente que um forte contra-enquadramento não tenha se oposto a esses processos. Mesmo sem reivindicar a ideia de 'gênero', a DAIA teve que "evitar confrontos com grupos fundamentalistas", isto é, religiosos. As feministas, por sua vez, sofreram forte oposição desses mesmos grupos. Insatisfeitas, elas queriam mais que um 'plano', queriam a aprovação de um anteprojeto de "Lei de saúde sexual, reprodutiva e materno-perinatal". Contudo, em quase uma década de luta, permanecem "proyectos de leyes trabajados hace varios periodos legislativos que por oposición de sectores conservadores fueron rechazados o incluso no llegaron a presentarse, como [e.g.] el de la ley sobre salud sexual y reproductiva y materno perinatal" (Montórfano, 2015, p. 152).

Nas duas versões seguintes do Plan de Salud Sexual y Reproductiva (2009-2013 e 2014-2018), 'gênero' permanece como ideal que dá o enquadramento mais amplo pautando os respectivos objetivos estratégicos. No entanto, enquanto a versão de 2009 inova falando de "participação social" - marca discursiva das forças e ideias que guiaram a eleição e a lógica de ocupação de cargos executivos do então presidente Fernando Lugo -, na última versão o objetivo estratégico incorpora originalmente a ideia de

20 Tomamos emprestada a divisão proposta por Pires e Gomide (2016) que dividem a noção de capacidade estatal em duas dimensões: técnico-administrativa e político relacional, para apenas sugerir que a dimensão ideacional está ausente dessa literatura de modo que a noção de "capacidade cognitiva" seria bem-vinda aí. 
'interculturalidade', cujas raízes e interações socioestatais restam ser compreendidas. Nos dois planos, porém, a ideia 'gênero' muda de status de modo a ultrapassar o nível normativo para ser aproximada das causas de fenômenos violentos e das ações contra eles: em 2009 a "Prevenção e atenção a pessoas em situação de violência intrafamiliar e violência baseada em gênero" é um 'âmbito' do Plan, ${ }^{21}$ para tornar-se uma "área estratégica” na versão de 2014. Passemos, por fim, à segunda política pública, se não norteada, permeada pela ideia de 'gênero' e pelas interações pró e contra ela.

Promulgada em 2000, a "Ley contra la violência doméstica”, doravante Lei 1600 , estabelece as normas e medidas de proteção relativas à "persona que sufra lesiones, maltratos físicos, psíquicos o sexuales por parte de uno de los integrantes del grupo familiar, que comprende el originado por el parentesco, en el matrimonio o unión de hecho, aunque hubiese cesado la convivencia, asimismo en el supuesto de parejas no convivientes y los hijos, sean o no comunes" (Art. $1^{\circ}$ ). Embora não seja possível refazer sua trajetória legislativa, é ponto pacífico no feminismo paraguaio o peso das organizações e militantes da CMP, bem como de sua aliança com a então ministra da Secretaria da Mulher, num esforço de dois anos entre a formulação do anteprojeto de lei e da sua aprovação. De modo interessante, como que contornando quaisquer eventuais oposições, esse instrumento não fala propriamente em "violência de gênero", mas em "violência doméstica”, elencando em seus artigos as instituições estatais responsáveis por acolher denúncias, proteger vítimas e punir agressores.

21 Aí, neste subnível do plano, “violência baseada em gênero" designa "una manifestación de discriminaciones, desigualdades y asimetrías de poder, generalmente de los varones sobre las mujeres, por lo que se ejerce una violencia sobre éstas por el solo hecho de ser mujeres" (Paraguay, 2009, p. 22). 
Em sua avaliação dos cinco anos pós-Beijing, ${ }^{22}$ as feministas da CMP consideravam a Lei 1600 um "avanço legal", mas com a seguinte reserva: "as maiores dificuldades estão vinculadas à escassez de investigações sobre o tema, ao registro dos casos de violência e, especialmente, à aplicação das medidas jurídicas para levar adiante as denúncias" (Martínez, O., 2001, p. 72). ${ }^{23}$ Essas reservas quanto à aplicação da lei e proteção das mulheres se reproduzem, adiante, nas recomendações do Comitê CEDAW ao Estado paraguaio.

El Comité exhortó al Estado parte a que estableciera albergues y otros servicios para las víctimas de la violencia. El Comité invitó al Estado parte a que redoblara sus esfuerzos para sensibilizar a los funcionarios públicos, especialmente los funcionarios encargados de hacer cumplir la ley [...] e inculcar[les] la idea que la violencia era $[. .$.$] inadmisible y constituía una discriminación$ contra la mujer (Comité CEDAW apud Cladem PY, CMP, CDE, 2005, p. 216-217).

Dotado de formas discriminatórias e sexistas de classificação, ${ }^{24} \mathrm{o}$ Estado paraguaio contava com uma lei contra a violência doméstica, mas não tinha uma infraestrutura de proteção afinada ao instrumento sensível a tal forma de violência; quer dizer, embo-

${ }^{22}$ Cf. Implementación de la Plataforma de Beijing en Paraguay 1995-2000: informe no gubernamental (CMP, 2001).

${ }^{23}$ Crítica similar aparece no relatório anual da Codehupy, importante articuladora civil paraguaia de organizações de defesa dos direitos humanos; "Las diferentes administraciones responsables de registrar los casos de violencia contra las mujeres utilizan soportes y definiciones distintas, con lo cual metodológicamente es imposible cuantificar la magnitud del problema" (Martínez, Santaella, 2002, p. 148).

${ }^{24}$ Cf. "Una investigación realizada sobre el tema releva [...] trato discriminatorio hacia la mujer: “[...] Las mujeres víctimas son objeto de interrogatorios improcedentes, donde se sienten juzgadas en lugar de apoyadas' [...]. También se relevan datos que muestran cómo, en delitos de coacción sexual, la defensa del agresor se centra en la vestimenta de la víctima y en ataques a la vida personal de la misma" (Cladem PY, CMP, CDE, 2005, p. 78). 
ra detivesse capacidade jurídica, lhe faltavam capacidades cognitivas e técnico-administrativas correlatas e necessárias à consecução daquela lei.

Ao mesmo tempo em que seguiram produzindo conhecimento, ${ }^{25}$ com suas formas de investigação sobre a "violência doméstica e intrafamiliar", ${ }^{26}$ as feministas paraguaias forjaram pontes e arenas de interação com funcionários públicos e, especialmente, com operadores de justiça e polícia para dar conta de tal limitação cognitiva. A primeira dessas pontes foi a redação do Manual de la Ley 1600/00. 'Contra la violência doméstica': explicación y aplicación, desenvolvido pela advogada feminista Clara Rosa Gagliardone Rivarola. Em seu parágrafo de abertura, afirma que a "violência é um fenômeno 'normal' dentro da estrutura familiar, de acordo com os dados estatísticos. Está apoiada em valores culturais nascidos de uma concepção hierárquica, onde as relações abusivas se dão, preferentemente, pela relação sexo/gênero e idade" (Gagliardone, 2002, p. 5). Todo o trabalho argumentativo do Manual se centra em desnaturalizar a violência dentro de casa: "é muito difícil falar de violência no lar" "muitas pessoas a justificam ou a negam"; "a sociedade acha que, apesar dos milhares de casos registrados, o lar é um lugar seguro". Quer dizer, a generificação se dá aí via sensibilização dos esquemas intelectivos dos operadores a quem se dirige o manual, não só pelo caminho narrativo argumentativo, mas também pelo conjunto de normativas internacionais ao qual o Estado paraguaio aderiu ao longo da década de $1990 .{ }^{27}$

Outra forma pela qual o feminismo paraguaio interpelou a aplicação da Lei 1600 foi o Guia de capacitación 'Género, acceso a la

${ }^{25}$ Cf. Perissinotto e Szwako (2017).

${ }^{26}$ Ver C. Soto, M. González y M. Elías (2003), Encuesta Nacional sobre Violencia Doméstica e Intrafamiliar, publicada pelo Centro de Documentación y Estudios (CDE).

27 Como, por exemplo, a Convenção Interamericana para Prevenir, Sancionar e Erradicar a Violência contra a Mulher, também chamada de 'Convenção do Belém do Pará, sancionada no país em 1995. 
justicia y violência contra las mujeres'para operadores y operadoras de justicia (Cladem PY, 2008), elaborado por Cladem Paraguay em aliança com agências do Judiciário e do Executivo, ${ }^{28}$ bem como apoio de organizações civis e do sistema internacional. ${ }^{29} \mathrm{~A}$ ideia de 'gênero' é, a um só tempo, "ponto de partida”, 'base' e "eixo transversal" do guia. Seu objetivo é "articular, en un nivel teórico y práctico, los [tres] ejes 'Género, acceso a la justicia y violencia contra las mujeres' [...] en la capacitación a operadores y operadoras de justicia” (idem, 2008, p. 8). Nesse sentido, à diferença do Plan de saúde sexual e reprodutiva, o guia não se inscreve em âmbito normativo; à semelhança do manual, ele interpela o esquema classificatório (e, não raro, discriminatório) daqueles funcionários que conformam a burocracia de rua vis- $\dot{a}-v i$ s a casa - se e quando violenta. Para que a Lei 1600 ganhe força, o guia lhes capacita cognitivamente, isto é, torna inteligível a "cultura patriarcal que opera a través de mitos y prejuicios en los operadores y operadoras de justicia que minimizan la gravedad del problema y buscan dejar de lado medidas pertinentes. En muchos casos revictimizan a la mujer y refuerzan la opresión" (idem, 2008, p. 32).

O ritmo da generificação estatal específica e relativamente às políticas de combate à violência contra as mulheres seguiu caminho consistente, apesar de tortuoso e limitado em seu alcance. Nos âmbitos Executivo e Judiciário, os Ministérios da Mulher, do Interior (polícia nacional), e da Sáude, bem como a Corte Suprema de Justiça, têm conjugado esforços que desaguam

${ }^{28}$ Cf. "Son varias las dependencias vinculadas con la justicia que participan en este emprendimiento conjunto. Entre ellas, podemos nombrar a la Dirección de Derechos Humanos del Poder Judicial y al Área de Género de esa Dirección, al Ministerio Público y al Ministerio de la Defensa Pública. El planteamiento es convertir en obligación de los operadores y operadoras de justicia del país el derecho a la educación en derechos humanos" (Cladem PY, 2008, p. 5).

29 Cf. "Nuestra gratitud a la Fundación Kuña Aty [...] así como también al Fondo de Población de las Naciones Unidas (UNFPA) y el Fondo de Desarrollo de las Naciones Unidas para la Mujer (Unifem), por respaldar este emprendimiento" (Cladem PY, 2008, p. 4). 
em ações como o Plan Nacional Contra la Violencia Hacia las Mujeres, o Programa Nacional de Prevención y Atención Integral de Víctimas de Violencia de Género, Doméstica e Intrafamiliar e o Comité Interinstitucional de Atención Integral de la Violencia por Razones de Género, para citar apenas alguns. Quanto à incapacidade metodológica do Estado paraguaio em registrar e mensurar esse fenômeno violento, vale mencionar a criação, entre 2010 e 2012, de um Registro Unificado de Servicios Prestados a Víctimas de Violencia Basada en Género, cujos resultados são, porém, mui limitados aos olhos das organizações feministas (Cf. Gonzalez, 2015a).

Bem mais recente, a única inovação institucional que teve fôlego e ambição maiores que a Lei 1600 foi a "Ley de Protección integral a las mujeres, contra toda forma de violencia" (5777/2016), também conhecida no país como a "Ley por Ellas". Sua principal contribuição é a tipificação da noção de 'feminicídio' ou de "violência feminicida" ( $\left.\operatorname{art} .6^{\circ}\right)$. A primeira versão do anteprojeto desta lei foi proposta, em 2012, pelo então recém-criado Ministério da Mulher e por sua ministra, ${ }^{30}$ Gloria Rubin. Com a dupla concepção de dar enfoque global ao fenômeno e tipificar o feminicídio, ${ }^{31}$ a proposta de 2012 foi duramente criticada e rejeitada por militantes feministas e também pelas câmaras do Poder Legislativo. ${ }^{32} \mathrm{Em}$ 2014, modificado com contribuições feministas, o anteprojeto é

30 Em 2012, após o impeachment de F. Lugo, a Secretaria da Mulher mudou de status e de nome, se tornando o Ministério da Mulher.

31 Uma das raízes intelectuais dessa figura jurídica no país é a própria Rubin; veja G. Rubin e A. Maciel (2005) 'El Señor es contigo...' Feminicidio en Paraguay.

32 Cf. "Aparte de objetar la falta de participación de las organizaciones de mujeres en una iniciativa legislativa de gran importancia, el proyecto presentado por los poderes del Estado fue criticado por ser considerado muy extenso, de poca aplicabilidad, por crear definiciones desconociendo las que ya están establecidas en instrumentos internacionales y son parte del marco legal paraguayo, y por establecer una excesiva judicialización de los casos de violencia; además, crea numerosa instancias y no determina de dónde provendrán los presupuestos necesarios para implementar las medidas incluidas en el proyecto, entre otras críticas señaladas en diversos espacios que organizaciones sociales generaron para discutir dicho proyecto" (Gonzalez, 2015a, nota 108). 
reapresentado por Rocio Casca, deputada aliada e presidenta da Comissão de Gênero da Câmara dos Deputados, sendo desta vez criticado tanto "por legisladoras y legisladores como por parte de sectores [...] relacionados a grupos conservadores y de iglesias. Los principales puntos en cuestión se refieren a la inclusión de la palabra género $[. .].[y]$ algunos tipos de violencia como [...] la violencia feminicida" (Gonzalez, 2015b, p. 408).

A versão aprovada ao final de 2016 ficou sem menção a 'gênero'. Nesse sentido, a trajetória legislativa da "Ley por Ellas" está inscrita numa linha de vitórias parciais do conservadorismo naquele país. ${ }^{33}$ Vitória das organizações e alianças do movimento fundamentalista cujo contraenquadramento tem tentado fazer da ideia de 'gênero' uma 'ideologia' (uma suposta “ideologia de gênero") ${ }^{34}$ e cujos resultados e esforços chegaram, naquele mesmo ano, à proposta de uma "Bancada Parlamentar pela Vida e pela Família”. Essa vitória foi, porém, parcial. Se a ideia de 'gênero' não permeou a lei, as feministas conseguiram, nas disputas textuais e discursivas travadas nas antessalas legislativas com apoio de suas aliadas e frente ao contraenquadramento, emplacar seus ideais tirando da "Ley por Ellas" medidas de proteção de lógica familista e revitimizante, típica das medidas de viés conciliador. Tortuosa, a generificação segue com avanços e limites: avanços centrados no arco de alianças e interações feministas e limites impostos pela força do contramovimento religioso.

33 Cf. "Entre 2004 y 2010, se discutió una serie de proyectos de ley en el Parlamento paraguayo en materia de derechos sexuales, reproductivos y no discriminación en todas sus formas. Estos proyectos son: (1) ley que crea un programa de prevención y asistencia a las víctimas de hechos punibles contra la autonomía sexual y contra menores; (2) de salud sexual, reproductiva y materno perinatal; (3) contra todas formas de discriminación; y (4) marco rector pedagógico sobre educación de la sexualidad. Ninguna de estas iniciativas ha sido aprobada, gran parte como resultado de la presión de grupos conservadores mediante una articulada campaña de desinformación" (Negrete, 2015, nota 2).

34 Para uma das raízes latino-americanas intelectuais da ideia de "ideologia de gênero", ver www.staffcatholic.net/archivos/lexicon/ideologiadegenero.pdf. 


\section{Conclusões}

A observação dos caminhos intelectivos da noção de 'gênero' por meio da reconstrução das ações e interações feministas permite reconhecer a riqueza da aproximação entre os debates da virada ideacional e de institucionalização de demandas dos movimentos sociais em políticas públicas. De um ponto de vista mais amplo, se nota como o notório déficit na capacidade instalada, seja na saúde pública ou no combate à violência contra a mulher, modula a ação das organizações feministas e suas coalizões. Mais especificamente, no contexto de Beijing, a forma pela qual o 'gênero' desempenhou função identitária é, simultaneamente, significativa da unificação de um 'nós' feminista, de uma demanda feita ao Estado paraguaio, bem como de modelos de sociedade e de Estado alternativos aos vigentes. Ora, à ênfase demasiado identitária do debate dos chamados novos movimentos sociais escapa a sobreposição contextual de lógicas estratégicas e simbólicas da ação dos movimentos. À la Campbell, é dessa mesma dimensão expressiva que tratam as tensões e oposições entre enquadramento e contraenquadramento, entre coalizões pró-'gênero' e contra ele. Observando-se as reações antifeministas desde Beijing até hoje, é possível notar como a generificação das políticas públicas parece colocar, não em jogo, mas em xeque alguns dos mais nobres, e mais bélicos, sentimentos públicos paraguaios - ao menos, segundo os discursos do contramovimento religioso.

Do ponto de vista analítico, os casos de generificação da política de combate à violência contra a mulher e de direitos sexuais e reprodutivos permitem extrair uma aposta heurística prenhe de consequências: no âmbito da diferenciação interna à noção de capacidade estatal dividida entre capacidades político-relacionais e técnico-administrativas, nos é possível sugerir o discernimento do aspecto cognitivo das capacidades. $\mathrm{O}$ caso das formas de sensibilização e conscientização de operadores e operadoras de justiça com 
relação à primeira lei de combate à violência contra a mulher no Paraguai encerra adequadamente os limites de uma noção de capacidade estatal que não leve em conta os esquemas mentais de classificação de quem opera os mecanismos de justiça e que, portanto, faz ou não faz valer tais mecanismos. É mais: queremos sugerir que a noção de capacidade cognitiva não pende analiticamente para o lado técnico-administrativo nem pende ao político-relacional; ao contrário, ligada a ambos, a capacidade cognitiva (isto é, a condição intelectiva para a apreensão de determinadas questões e soluções práticas e para a elevação delas ao domínio de intervenção público-estatal) parece operar como uma espécie de elo entre as dimensões relacional e administrativa. Quer dizer, a construção de capacidades cognitivas é, para nós, parte constitutiva seja das coalizões e redes das quais os movimentos sociais fazem parte na concepção e formulação de determinadas políticas (sobretudo, as políticas sociais), seja dos leques e instrumentos pelos quais se dão a consecução dessas mesmas políticas. Fica, pois, sugerida às análises dedicadas a interações, ideias e institucionalização, a nossa proposta de testar os limites e alcances da compreensão da capacidade cognitiva como dimensão também explicativa das dinâmicas e interações pelas quais movimentos sociais transformam seus ideais e demandas em políticas públicas.

\section{REFERÊNCIAS}

ALVAREZ, Sonia et al. Encontrando os feminismos latino-americanos e caribenhos. Revista Estudos Feministas, 2003, v. 11, n. 2, pp. 541-575.

BERMAN, Sheri. The Social Democratic Moment. London: Harvad University Press, 1998.

BLYTH, Mark. Any More Bright Ideas? The Ideational Turn of Comparative Political Economy. Comparative Politics, 1997, v. 29, n. 2, pp. 229-250. Disponível em: <http://www.jstor.org/stable/422082?origin=crossref $>$. 
CAMPBELL, John. L. Institutional Analysis and the Role of Ideas in Political Economy. Theory and Society, 1998, v. 27, n.3, pp. 377-409.

CHIN-QUEE, Dawn. In Paraguay, Both IUDs and Contraceptive Pills come with 'Strings Attached'. Revista Panamericana de Salud Pública, 2004, v. 16, n. 2, pp. 144-147.

CLADEM PARAGUAY. Comité de América Latina y el Caribe para la Defensa de los Derechos de la Mujer - Paraguay. Guía de capacitación 'Género, acceso a la justicia y violência contra las mujeres para operadores y operadoras de justicia. Asunción: Cladem, 2008.

CLADEM PARAGUAY; CMP; CDE. Comité de América Latina y el Caribe para la Defensa de los Derechos de la Mujer - Paraguay; Coordinación de Mujeres del Paraguay y Centro de Documentación y Estudios. Informe Sombra CEDAW: vigilancia ciudadana sobre los derechos humanos de las mujeres en Paraguay. Asunción: Cladem; CMP; CDE, 2005.

CMP. Coordinación de Mujeres del Paraguay. Mujeres paraguayas camino a Beijing/Kuña Paraguay Beijing Rapere: documento no gubernamental del Paraguay para el Foro Internacional sobre la Mujer de Beijing 95. Asunción: [s.n.], 1994 .

CMP. Coordinación de Mujeres del Paraguay. Implementación de la Plataforma de Beijing en Paraguay 1995-2000: informe no gubernamental. [s.l.: s.n.], 2001.

CODEHUPY. Síntesis de las recomedaciones. In: Codehupy. Derechos Humanos en Paraguay 2003. Asunción: Codehupy, 2003.

ECHAURI, Carmen et al. Hacia una presencia diferente: mujeres, organización y feminismo. Asunción: CDE, 1992.

FRANCO, Jean. The Gender Wars. NACLA Report on the Americas, 2 abr. 1996. Disponível em: <http://www.hartford-hwp.com/archives/42a/038. html>.

GAGLIARDONE, Clara Rosa. Manual de la Ley 1600/00 'Contra la violência doméstica': explicación y aplicación. Asunción: Proyeto RedCidem; Secretaría de la Mujer, 2002.

GONZALEZ, Myrian. Un Estado violento para las mujeres: sin voluntad política ni presupuestos para erradicar la violencia de género. In: Codehupy. Derechos Humanos en Paraguay 2015. Asunción: Codehupy. 2015b, pp. 403420.

GONZALEZ, Myrian. Violencia contra la mujer. In: CDE; Cladem PY; CMP; Codehupy; EFC. Paraguay a 20 años de Beijing 1995: informe de la sociedad civil sobre el cumplimiento de la Plataforma de Acción de la IV Conferencia Internacional sobre la Mujer. Asunción: ONU Mujeres, 2015a. Disponível em: <http://www.cde.org.py/wp-content/uploads/2015/12/libro-BEIJING-WEB_CD.pdf $>$. Acesso em: 30 jun. 2018. 
GOUREVITCH, Peter. Politics in Hard Times: Comparative Responses to International Economic Crises. Ithaca, NY: Cornell University Press, 1986.

HAY, Colin. Narrating Crisis: The Discursive Construction of the 'Winter of Discontent.' Sociology, 1996, n. 30, pp. 253-277.

JACOBS, Alan. M. Process-tracing the Effects of Ideas. In: Bennett, Andrew; Checkel, Jeffrey (Ed.) Process Tracing in the Social Sciences: From Metaphor to Analytic Tool. Cambridge, UK: Cambridge University Press, 2015, pp. 41-73.

KINGDON, John W. Agendas, Alternatives, and Public Policies. Essex: Pearson, 2014.

LINDGREN-ALVES, José Augusto. Relacões internacionais e temas sociais: a década das conferências. Brasília: Funag/IBRI, 2001.

LOMBARDO, Emanuela; MEIER, Peter. European Union Gender Policy Since Beijing. Shifting Concepts and Agendas Europe. In: Verloo, Mieke (Org.). Multiple Meanings of Gender Equality in Europe. Budapest: Central European University Press, 2007.

MARTÍNEZ, Esperanza. Derecho a salud. In: Codehupy. Informe de Derechos Humanos 2001. Asunción: Codehupy, 2001.

MARTÍNEZ, Ofelia. La violencia contra la mujer. In: CMP. Implementación de la Plataforma de Beijing en Paraguay 1995-2000: informe no gubernamental. Asunción: CMP, 2001, pp. 71-86.

MARTÍNEZ, Ofelia; SANTAELLA, Encarnación. Derechos de las mujeres: avances legislativos sin cambios culturales. In: Codehupy. Derechos Humanos en Paraguay 2002. Asunción: Codehupy, 2002, pp. 143-166.

MELUCCI, Alberto. Challenging Codes. Collective Action in the Information Age. Cambridge, UK: Cambridge University Press, 2003.

MONTÓRFANO, María Gloria. La salud en Paraguay: ¿retrocedió como derecho? De la teoría a la práctica: una brecha que afecta a la población (Derecho a la salud). In: Codehupy. Derechos Humanos en Paraguay 2015. Asunción: Codehupy, 2015, pp. 149-164.

MMP. Multisectorial de Mujeres del Paraguay. Criticas y sugerencias al Capitulo 9: promoción de la mujer del Plan Nacional de Desarrollo Económico y Social 89/90. Asunción: MMP, 1989.

MMP; CMP. Multisectorial de Mujeres del Paraguay; Coordinación de Mujeres del Paraguay. Bases para el proyecto de ley para la Secretaría de la Mujer. Asunción: [s.n.],1991.

NARVÁEZ, Carmen. Sistematización de la experiencia del Comité DAIA Paraguay. Washington: Futures Group; Health Policy Project, 2012. 
NEGRETE, Martín. Universalizar los DDHH de las personas que viven con VIH, un nuevo desafio para los próximos años (Derechos de las personas viviendo con VIH y Sida). In: Codehupy. Derechos Humanos en Paraguay 2015. Asunción: Codehupy, 2015, pp. 71-84.

OMS. Organização Mundial da Saúde. Planificación familiar: um manual mundial para proveedores. 2011. Disponível em: <http://www.who.int/ reproductivehealth/publications/family_planning/9780978856304/es/>. Acesso em: 30 jun. 2018.

PERISSINOTTO, Renato. SZWAKO, José. Movimentos sociais como teóricos políticos. Lua Nova, 2017, n. 102, pp. 231-263.

PIRES, Roberto; GOMIDE, Alexandre. Governança e capacidades estatais: uma análise comparativa de programas federais. Revista de Sociologia e Politica, 2016, v. 24, n.58, pp. 121-143.

RODRÍGUEZ-ALCALÁ, Guido. Ideologia autoritária. Trad. Luiz Moreira e Marcela Quinteros. Brasília: Funag/IPRI, 2005. (Coleção América do Sul)

RUBIN, Gloria; MACIEL, Alejandro. 'El Señor es contigo...' Feminicidio en Paraguay. Asunción: Fundación Kuña Aty, 2005.

SCHMIDT, Vivien A. Taking Ideas and Discourse Seriously: Explaining Change Through Discursive Institutionalism as the Fourth 'New Institutionalism. European Political Science Review, 2010, v. 2, n. 1, pp. 1-25.

SOTO, Clyde; GONZALEZ, Myrian; ELÍAS, Margarida. Encuesta Nacional sobre Violencia Doméstica e Intrafamiliar. Asunción: CDE, 2003.

SZWAKO, José. 'Del otro lado de la vereda': luta feminista e construção democrática no Paraguai pós-ditatorial. 2012. 440 p. Tese (Doutorado em Ciências Sociais) - Universidade Estadual de Campinas, Campinas, 2012.

SZWAKO, José. O 'mau desempenho' de Lugo: gênero, religião e contramovimento na última destituição presidencial paraguaia. Opinião Pública, 2014, v. 20, n.1, pp. 132-155.

WALBY, Sylvia. Gender Mainstreaming: Productive Tensions in Theory and Practice. Social Politics, 2005, v.12, n.3, pp. 321-343.

ZUCCOLILLO, Carolina Rodriguez. Língua, nação e nacionalismo: um estudo sobre o guarani no Paraguai. 2000. 254 p. Tese (Doutorado em Linguística) Universidade Estadual de Campinas, Campinas, 2000. 


\section{DocumentOS OFICIAIS}

ONU. Organización de las Naciones Unidas. Informe de la Cuarta Conferencia Mundial sobre la Mujer Beijing (4-15 sep. 1995). A/CONF.177/20/Rev.1. Nova York: ONU, 1995. Disponível em: www.un.org/womenwatch/daw/beijing/pdf/ Beijing\%20full\%20report\%20S.pdf.

PARAGUAY. República del. Plan Nacional de Salud Reproductiva. Versión postCairo. 1997a. Disponível em: www.unfpa.org.py/subprogramas/salud/index.php. Acesso em: 4 abr. 2017.

PARAGUAY, República del. Plan Nacional de Igualdad de Oportunidades para las Mujeres, 1997-2001. Asunción: Secretaría de la Mujer; Presidencia de la República, $1997 \mathrm{~b}$.

PARAGUAY, República del. Plan Nacional de Salud Sexual y Reproductiva, 20032008. 2003. Disponível em: www.unfpa.org.py/download/pdf_pnssr.pdf. Acesso em: 11 abr. 2017.

PARAGUAY, República del. Plan Nacional de Salud Sexual y Reproductiva, 20092013. 2009. Disponível em: www.cepep.org.py/archivos/Plan\%20Nacional\%20 SSR.pdf. Acesso em: 15 abr. 2017.

PARAGUAY, República del. Plan de Igualdad e no Discriminación en la Función Pública. 2011. Disponível em: www.sfp.gov.py/sfp/archivos. Acesso em: 15 maio 2017.

PARAGUAY, República del. Plan Nacional de Salud Sexual y Reproductiva, 20142018. 2014. Disponível em: <http://www.cepep.org.py/archivos/PNSSR2014. pdf>. Acesso em: 15 abr. 2017.

STP. Secretaría Técnica de Planificación. Plan Nacional de Desarrollo Económico y Social. [s.l.; s.n.], 1989-1990. 


\section{SOBRE OS AUTORES}

\section{Adrian Gurza Lavalle}

É doutor em Ciência Política pela Universidade de São Paulo (USP) e realizou pós-doutorado no Institute of Development Studies, Inglaterra. É professor do Departamento de Ciência Política da USP, pesquisador do Centro de Estudos da Metrópole (CEM) e do Centro Brasileiro de Análise e Planejamento (Cebrap), onde é coordenador do Núcleo de Pesquisa Democracia e Ação Coletiva (NDAC). Seus últimos livros são Intermediation and Representation in Latin America - Actors and Roles Beyond Elections, com Gisela Zaremberg e Valeria GuarnerosMesa (Plalgrave Macmillan); O papel da teoria politica contemporânea. Justiça, Constituição, democracia e representação, com Álvaro de Vita e Cícero Araújo (Alameda) e O horizonte da politica. Questôes emergentes e agendas de pesquisa (Unesp/CEM/Cebrap).

\section{Euzeneia Carlos}

É doutora em Ciência Política pela Universidade de São Paulo (USP) e realiza pós-doutorado no Centro Brasileiro de Análise e Planejamento (Cebrap). É professora do Departamento de Ciências Sociais da Universidade Federal do Espírito Santo (Ufes), onde coordenadora o Núcleo Participação e Democracia (Nupad). É pesquisadora do Cebrap, pelo Núcleo Democracia e Ação Coletiva (NDAC). Publicou três livros: Movimentos sociais e instituiçôes participativas: efeitos do engajamento institucional no contexto pós-transição (Fino Traço); Controle social e politica redistributiva no orçamento participativo (EdUfes) e 
Sociedade civil e politicas públicas: atores e instituições no Brasil contemporâneo, com Wagner M. Romão e Osmany P. Oliveira (Argos). Organizou, com José Szwako e Monika Dowbor, o número temático "Movimentos sociais, sociedade civil e participação" da Revista Brasileira de Informação Bibliográfica em Ciências Sociais - BIB.

\section{Monika Dowbor}

É doutora em Ciência Política pela Universidade de São Paulo (USP) e realizou pós-doutorado pelo Centro de Estudos da Metrópole (CEM). É professora do Programa de Pós-Graduação em Ciências Sociais da Universidade do Vale do Rio dos Sinos (Unisinos) e pesquisadora do Cebrap. Trabalha com Teorias de Movimentos Sociais, Abordagens de Políticas Públicas e do Institucionalismo Histórico, com ênfases nos temas: interações socioestatais, organizações da sociedade civil, movimentos sociais, organizações de movimentos sociais, efetividade de movimentos sociais, políticas públicas, avaliação de políticas públicas. Organizou, com José Szwako e Euzeneia Carlos, o número temático "Movimentos sociais, sociedade civil e participação" da Revista Brasileira de Informação Bibliográfica em Ciências Sociais - BIB.

\section{José Szwako}

É doutor em Ciências Sociais pela Universidade de Campinas (Unicamp). Realizou pós-doutorado pelo Centro de Estudos da Metrópole (CEM), é pesquisador do Centro Brasileiro de Análise e Planejamento (Cebrap), onde compõe o Núcleo Democracia e Ação Coletiva. É professor e pesquisador do Instituto de Estudos Sociais e Políticos (IESP) da Universidade Estadual do Rio de Janeiro (UERJ). Investiga os impactos institucionais advindos da ação de grupos e movimentos da sociedade civil. Realiza pesquisa na área de Feminismos na América Latina, Gênero e Sociologia Política. Organizou, com Monika Dowbor e Euzeneia Carlos, o número temático "Movimentos Sociais, Sociedade Civil e Participação" da Revista Brasileira de Informação Bibliográfica em Ciências Sociais - BIB. 


\section{Patrícia Tavares de Freitas}

É doutora em Sociologia pela Universidade Estadual de Campinas (Unicamp), realizou pós-doutorado no Centro de Estudos da Metrópole (CEM) e é pesquisadora do Centro Brasileiro de Análise e Planejamento (Cebrap), onde compõe o Núcleo Democracia e Ação Coletiva. Participa ainda dos grupos: Políticas Locais de Migração, no Instituto de Relações Internacionais da Universidade de São Paulo (IRI/USP) e Processos Migratórios e Saúde: Perspectivas Interdisciplinares, na Faculdade de Ciências Médicas da Santa Casa de São Paulo (FCMSCSP). Atua principalmente nos seguintes temas: migrações internacionais, sociologia urbana, transnacionalismo, economias étnicas, movimentos sociais, associativismo, políticas locais para migrantes e participação social.

\section{Maria do Carmo Albuquerque}

É doutora em Integração da América Latina pela Universidade de São Paulo (Prolam/USP) e mestre em Ciência Política pela Universidade Estadual de Campinas (Unicamp). É pesquisadora do Núcleo de Pesquisa Democracia e Ação Coletiva (NDAC) do Centro Brasileiro de Análise e Planejamento (Cebrap). Atuou como pesquisadora e docente no Mestrado Profissional Adolescente em Conflito com a Lei (Unian/SP) e no Instituto Pólis. Atua principalmente nos seguintes temas: movimentos sociais, sociedade civil, participação e controle social em políticas públicas, com ênfase em orçamentos participativos, conselhos gestores e políticas públicas de direitos do adolescente em conflito com a lei. Entre suas publicações destacam-se artigos em periódicos e livros organizados, como La construcción democrática desde abajo en el Cono Sur (Instituto Pólis, 2004).

\section{Flavia Rios}

É doutora em Sociologia pela Universidade de São Paulo (USP) e atualmente é professora adjunta da Universidade Federal Fluminense (UFF). Foi do corpo docente da Faculdade de Ciências Sociais da 
Universidade Federal de Goiás (2016) e Visiting Student Reasearcher Collaborator (VSRC) no Sociology Department, na Princeton University (2013). Escreveu em coautoria com Alex Ratts o livro Lélia Gonzalez (Selo Negro, 2010), biografia de uma intelectual negra e feminista no processo de democratização brasileira. Colaborou na elaboração do Dictionary of Caribbean and Afro-Latin American Biography (Oxford, 2016), organizado por Franklin W. Wright e Henry Louis Gates, Jr. Trabalha na área de sociologia política e da cultura, com ênfase nos estudos sobre ação coletiva, gênero, relações raciais, educação e políticas de ações afirmativas no ensino superior.

\section{Layla Pedreira de Carvalho}

É doutora em Ciência Política pela Universidade de São Paulo (USP), mestre em Sociologia pela Universidade de Brasília (UnB) e graduada em Ciência Política pela mesma instituição. É pesquisadora doNúcleo de Pesquisa Democracia e Ação Coletiva (NDAC) do Centro Brasileiro de Análise e Planejamento (Cebrap) e membro do Grupo de Estudos Gênero e Política (GEPÔ - DCP/USP). Tem como interesses de pesquisa: políticas públicas, movimentos feministas e de mulheres, direitos reprodutivos e justiça reprodutiva, transnacionalismo e feminismos transnacionais.

\section{Vera Schattan Coelho}

É doutora em Estado e Políticas Públicas pela Universidade Estadual de Campinas (Unicamp). É coordenadora do Grupo de Cidadania, Saúde e Desenvolvimento do Centro Brasileiro de Análise e Planejamento(Cebrap), pesquisadoradoCentrodeEstudosdaMetrópole (CEM), e professora do Programa de Pós-Graduação em Políticas Públicas da Universidade Federal do ABC. Conduziu vários estudos comparativos nas áreas de reforma dos sistemas previdenciários, sistemas de saúde e participação social. Publicou os livros Reforma da Previdência Social na América Latina (FGV); Participação e deliberação (34 Letras, com Marcos Nobre); Spaces for Change (Zed Books, com A. Cornwall); 
Novos espaços democráticos (Esfera Pública, com A. Cornwall); e Mobilizing for Democracy (Zed Books, com B. von Lieres).

\section{Renato Perissinotto}

É doutor em Ciências Sociais pela Universidade Estadual de Campinas (Unicamp), com pós-doutorado pela University of Oxford, Inglaterra. É professor da Universidade Federal do Paraná (UFPR), no Programa de Pós-Graduação em Ciência Política e no Programa de Pós-Graduação em Sociologia. Atualmente, é presidente da Associação Brasileira de Ciência Política (ABCP). É coeditor da Revista de Sociologia e Política e coordenador do Núcleo de Pesquisa em Sociologia Política Brasileira (UFPR). Em 2012, recebeu o prêmio de melhor obra científica, da Associação Nacional de Pós-Graduação em Ciências Sociais (Anpocs), concedido ao livro Marxismo como ciência social, em coautoria com Adriano Codato. Organizou e publicou, com José Szwako, o volume Curso livre de Teoria Politica (Appris). 
